Jáder dos Reis Sampaio

\title{
VOLUNTÁRIOS:
}

UM ESTUDO SOBRE A MOTIVAÇÃO DE PESSOAS E A CULTURA EM UMA ORGANIZAÇÃO DO TERCEIRO SETOR

São Paulo

Universidade de São Paulo

Faculdade de Economia, Administração e Contabilidade

2004 
Jáder dos Reis Sampaio

\section{VOLUNTÁRIOS: \\ UM ESTUDO SOBRE A MOTIVAÇÃO DE PESSOAS E A CULTURA EM UMA ORGANIZAÇÃO DO TERCEIRO SETOR}

Tese apresentada ao Curso de Doutorado em Administração da Faculdade de Economia, Administração e Contabilidade da Universidade de São Paulo como requisito parcial à obtenção do título de Doutor em Administração.

Orientadora: Profa. Dra. Maria Tereza Leme Fleury Universidade de São Paulo

São Paulo

Universidade de São Paulo

Faculdade de Economia, Administração e Contabilidade 2004 


\section{Dedicatória}

A Tatiana, minha esposa, por ter sido forte e ter me apoiado neste projeto, encarregando-se de tudo o que a distância me impediu de fazer. Acho que me casei com duas em corpo de uma.

Às filhas, Carolina e Júlia, por continuarem me amando e exigindo minha presença e não terem acatado, em tempo algum, as teses do abandono ou da negligência.

À Universidade de São Paulo, na pessoa de meus professores, dos servidores e de meus colegas, por terem me recebido como a um membro da família e contribuído significativamente para o desenvolvimento de minha carreira acadêmica e de minha vida profissional.

Aos meus concidadãos miseráveis, moradores da capital ou do interior, plenos de direitos e vazios de gozo, objeto de discursos e de fantasias, de medo e compaixão, paradoxalmente culpados e vítimas, na esperança de que sua condição passe a ser apenas um triste fato da nossa História e de que todos se tornem homens de cidadania, capazes de construir sua própria história. 


\section{Agradecimentos}

À orientadora, Profa. Maria Tereza Leme Fleury, que mesmo envolvida com mil obrigações impostas pelo cargo de diretora, sempre teve tempo e dedicação para esta tese e para com a preparação do seu autor.

Aos professores Dra. Ana Cristina Limongi França e Dr. José Afonso Mazzon, membros do exame de qualificação do presente trabalho, pelo profissionalismo, cuidado e atenção que dispensaram nas memoráveis quatro horas de críticas e sugestões ao projeto deste trabalho.

À Creche Espírita Futuro (nome fantasia), especialmente à diretoria da mantenedora e a sua coordenadora administrativa, por terem aberto as portas à pesquisa incondicionalmente e apoiado, com boa vontade, aos pedidos que lhes endereçávamos.

Ao Departamento de Psicologia da Universidade Federal de Minas Gerais, que me assegurou a licença e valorizou a qualificação, mesmo estando sob a contingência de redução de quadros imposta pelo Governo Federal.

Aos colegas do Departamento de Psicologia, que se interessaram pelo meu trabalho e nunca se negaram a ajudar e a "prosear" sobre ele.

Ao Professor Dr. Sandro Márcio da Silva, da Pontifícia Universidade Católica de Minas Gerais, que auxiliou este projeto desde o nascedouro.

Aos meus professores de Francês e Espanhol, por terem me introduzido nestes dois novos universos culturais nos últimos anos.

Ao Centro de Estudos em Administração do Terceiro Setor - CEATS, por ter aberto esta nova linha ao conhecimento administrativo na Faculdade de Economia Administração e Contabilidade da Universidade de São Paulo. 
“- Sou, sim.Vim do São Paulo... Como é que você está sabendo? Cheguei hoje...

- Me contaram, lá no comércio...

Turíbio riu. Cada vez mais gostava do caipirinha.

- Por que é que uns como você não vão também trabalhar lá? Podiam ganhar dinheiro, aprender a viver. Isto, por aqui, não é vida, é uma miséria magra de fazer dó!... Se você quiser ir, eu explico tudo direito, te ajudo com dinheiro, até".

Sagarana

João Guimarães Rosa 


\section{Resumo}

Para este trabalho realizou-se um estudo de caso em uma creche visando a identificar novas categorias de análise de cultura organizacional e motivação de voluntários em organizações de Terceiro Setor. O Terceiro Setor é concebido como o conjunto de organizações sem fins lucrativos, autogerenciadas, integrantes da sociedade civil, com finalidade pública ou coletiva. Foram revistas as teorias de motivação de Abraham Maslow, David McClelland e Joseph Nuttin, a partir das quais se desenvolveu um modelo complexo para o estudo deste fenômeno, que contempla necessidades fisiológicas, tendências e schematas, além dos próprios motivos. Os motivos são concebidos como projetos de ação baseados em relações exigidas entre indivíduo e ambiente. Após a revisão das teorias de cultura organizacional de Hofstede, Schein e Fleury, adotou-se o modelo de cultura organizacional de Fleury, acrescido da análise de ethos e visão de mundo (oriundas dos trabalhos de Clifford Geertz) de movimentos políticos, religiosos ou sociais subjacentes à organização. $\mathrm{O}$ estudo de caso contou com o recurso de triangulação de dados, a partir de múltiplas técnicas de pesquisa: observação participante, análise de documentos, história de vida e descrição de atividades. $\mathrm{Na}$ análise do movimento religioso subjacente à creche, encontra-se uma proposta de ethos e visão de mundo do Espiritismo depreendidos da leitura da obra de Allan Kardec e da revisão bibliográfica de estudos antropológicos em organizações espíritas brasileiras. A análise da história da organização mostrou existir um conflito entre um projeto de promoção social, idealizado pelo fundador, e uma obra social preocupada com o desenvolvimento pessoal e a oportunidade de realização de atividades humanitárias pelo voluntário, própria do movimento espírita, assim como 
convênio com o poder público municipal, que descaracterizou as atividades de creche como espaço de ação voluntária. Observou-se que os voluntários de um dos territórios da creche associam seus motivos não apenas às tendências a estabelecer contatos interpessoais afetuosos como também à consistência interna, com a construção de uma auto-imagem mais valorizada, e justificada por muitos dos schematas estudados. Observou-se também que o trabalho voluntário é, paradoxalmente, fonte de prazer, de desligamento de problemas oriundos de outros espaços de experiência e de sofrimento. Há, ainda, o desenvolvimento de alguns mecanismos de defesa individuais e coletivos para atenuar os efeitos desses aspectos negativos. O estudo corrobora a tese que advoga a necessidade de conhecimento mais substancial da cultura das organizações de Terceiro Setor, antes de se propor a adoção de técnicas de gestão oriundas do meio empresarial. 


\begin{abstract}
A kindergarten case study was done in order to identify new analysis categories from organizational culture and volunteer motivation for "third sector" organizations. Third sector is defined as the cluster of non-profitable, self governed, civil society organizations, with public or collective goals. Abraham Maslow, David McClelland and Joseph Nuttin's theories of motivation were revised. They were the base for a complex theoretical model that comprehends physiological necessities, tendencies and schemata, besides the motives, for the motivation study. Motives are action projects based upon required relationship between the individual and the environment. Hofstede, Schein and Fleury's theories of organizational culture were reviewed. This study adopted Fleury's model of organizational culture increased with the analysis of ethos and world-view (from Clifford Geertz studies), from political, religious or social movements subjacent to the organization. Case study was done using data triangulation techniques dealing with information obtained by participant observation, document analysis, life history and activities description. Allan Kardec's books and articles were used to build the ethos and world view of Brazilian Spiritism, besides the review of anthropological studies of spirit Brazilian organizations. Spiritism is the religious movement related to the kindergarten's volunteers. Organization's history analysis revealed a conflict between the founder's social promotion project and the conception beheld by the spiritist volunteers that is worried with the personal development and generating opportunities of humanitarian service. It showed an alliance with municipal public power that putted away the volunteer workforce from the kindergarten's activities. The volunteers from one of the influence territories of the organization affirmed the
\end{abstract}


association between gratification and the tendency to realize interpersonal affective contacts and the tendency to internal consistency, with a valorized self-image. There is a connection between the schemata identified and this internal consistency. Volunteer work is paradoxically a source of pleasure, distance from outsider problems and pain. It was observed some individual and collective defense mechanisms to protect volunteers from pain effects. This study corroborates the thesis that defends the necessity of third sector organization's substantive cultural knowledge before the proposal of management techniques from enterprises. 


\section{Lista de Ilustrações}

Figura 1: Classificação das organizações de Terceiro Setor 33

Figura 2: Modelo teórico dos estudos transnacionais segundo Smircich...................... 41

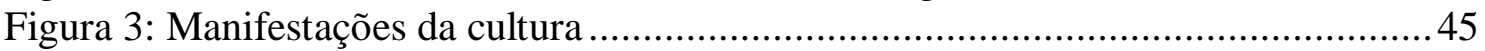

Figura 4: Níveis de análise da cultura organizacional de Schein .............................. 47

Figura 5: Níveis de apreensão da cultura organizacional de Fleury ............................53

Figura 6: Interação entre personalidade e ambiente, mostrando predição de comportamento

Figura 7: Apreensão da cultura pelo indivíduo, segundo McClelland.

Figura 8: Proposta de representação do modelo de Nuttin de motivação ...................... 113

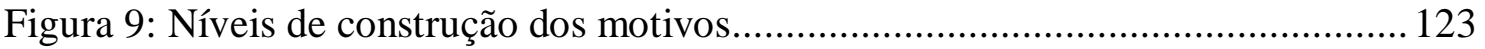

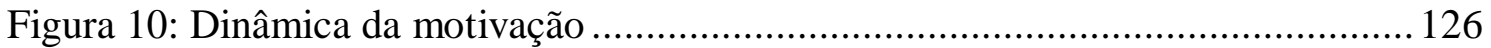

Figura 11: Níveis de análise da cultura de uma organização de Terceiro Setor............ 134

Figura 12: Técnicas de coleta de dados para a realização do estudo de caso................ 144

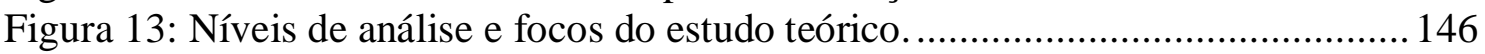

Figura 14: Programas sociais das sociedades espíritas paulistas................................ 161

Figura 15: Número de famílias assistidas por programa das sociedades espíritas

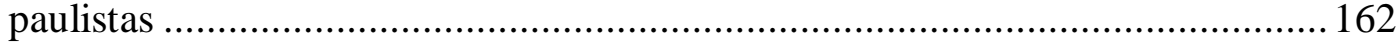

Figura 16: Primeira estrutura organizacional da Creche Futuro ................................ 184

Figura 17: Reforma da estrutura organizacional da Creche Futuro em 1986................ 186

Figura 18: Estrutura organizacional da Creche Futuro em 1998 ................................201

Figura 19: Estrutura organizacional da Creche Futuro em vigor............................... 202

Figura 20: Fontes de recursos financeiros da Creche Futuro ....................................... 209 


\section{Lista de Quadros}

Quadro 1:Diferentes padrões de estudos culturais em Administração ......................... 44

Quadro 2: Comparação feita por Maslow entre métodos de pesquisa ..........................61

Quadro 3: Síntese dos modelos de motivação ........................................................... 92

Quadro 4: Papel gerencial e necessidade de realização ........................................... 101

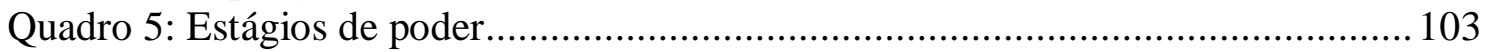

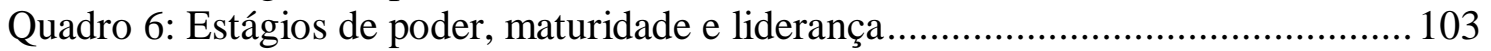

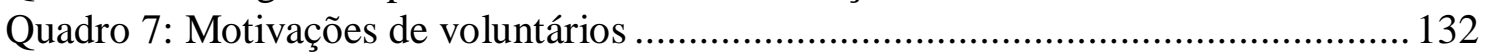

Quadro 8: Técnicas empregadas para o estudo de caso ............................................ 156

Quadro 9: Síntese do ethos e visão de mundo da obra kardequiana ........................... 170

Quadro 10: Ethos espírita brasileiro no estudo de alguns antropólogos ....................... 173

Quadro 11: Qualificações e documentação pública da Creche Futuro e de sua

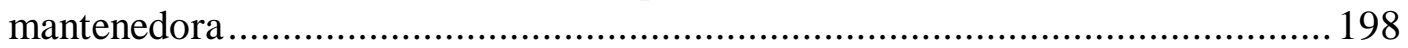

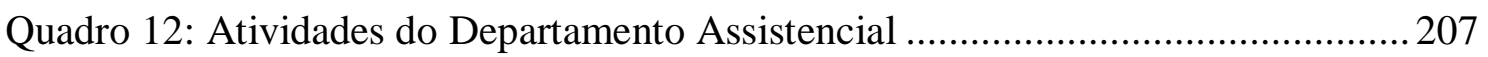

Quadro 13: Atividades do Departamento de Creche ................................................ 207

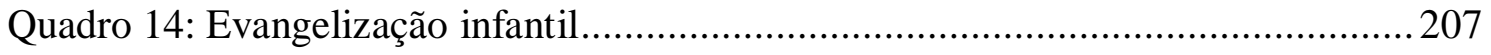

Quadro 15: Atividades do Departamento de Oficinas e Promoções............................ 208

Quadro 16: Atividades regulares do Departamento de Saúde......................................20 208

Quadro 17: Atividades sem vínculo departamental ................................................208

Quadro 18: Experiências anteriores dos voluntários entrevistados ...........................220

Quadro 19: Processo de socialização dos voluntários entrevistados ...........................223

Quadro 20: Tendências motivacionais dos voluntários............................................2225

Quadro 21 Principais schemata encontrados no discurso dos voluntários...................228 


\section{SUMÁRIO}

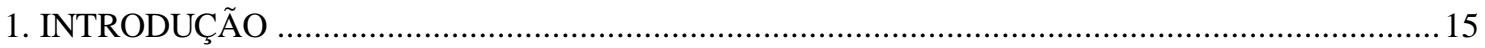

2. O TERCEIRO SETOR COMO OBJETO DA TEORIA ADMINISTRATIVA …..............................22

2.1. Sobre o conceito de Terceiro Setor ................................................................. 22

2.2 Pessoas jurídicas integrantes do Terceiro Setor no Brasil ................................. 25

2.3 A emergência do Terceiro Setor........................................................................ 26

2.4 A questão da identidade e classificação das organizações do Terceiro Setor ......29

2.5 Regulamentação do Terceiro Setor no Brasil ................................................. 35

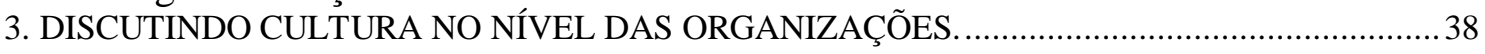

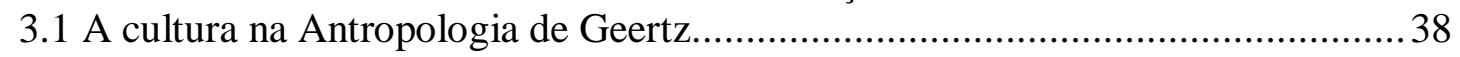

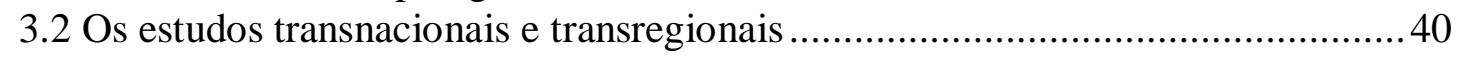

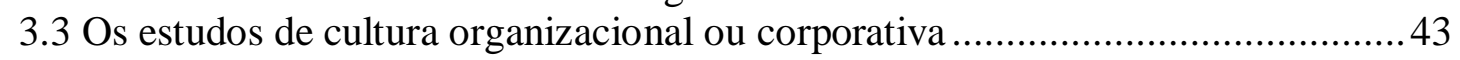

3.4 Pressupostos básicos: de Bion a Schein ...................................................... 48

3.5 A metodologia de análise da cultura organizacional proposta por Fleury............52

3.7 Articulando o estudo das estruturas organizacionais ao estudo de cultura...........54

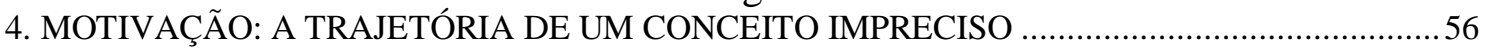

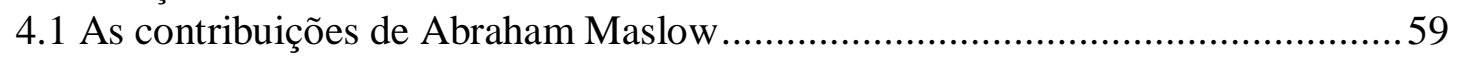

4.1.1 A visão de ciência e de homem, segundo Maslow ....................................6 60

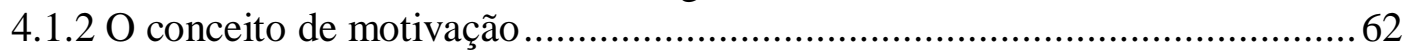

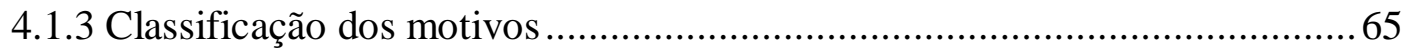

4.1.4 A proposição de hierarquia da preponderância das necessidades .................68

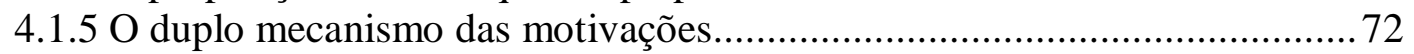

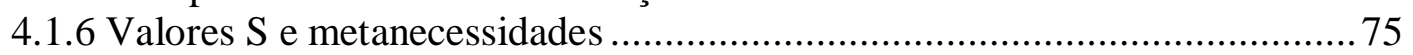

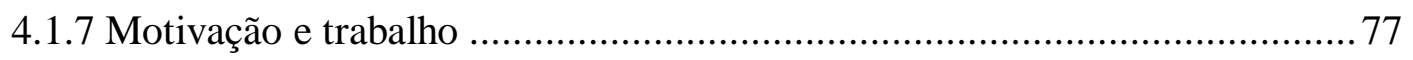

4.1.8 Reflexões críticas da teoria de motivação de Maslow ................................. 81

4.2 A motivação estudada por David McClelland ................................................... 83

4.2.1 Um modelo de interação entre a personalidade e o ambiente ...................... 85

4.2.3 A trajetória dos estudos de motivação. ..................................................91

4.2.4 Da literatura clínica aos postulados sobre a motivação .............................. 94

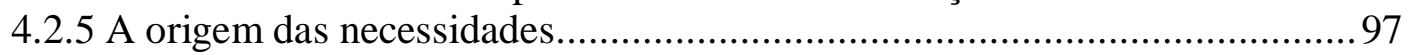

4.2.6 A necessidade de realização e o trabalho....................................................98

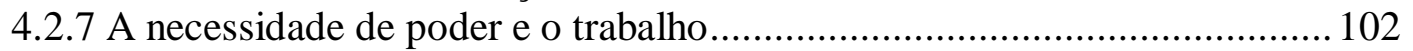

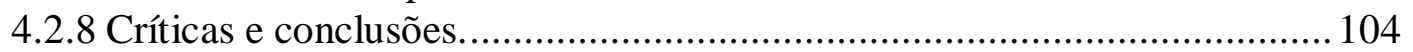

4.3 Joseph Nuttin: A motivação vista por um interacionista ................................. 106

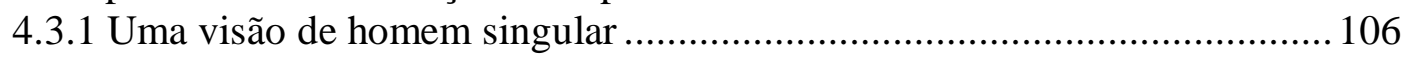

4.3.2 As noções de motivação revisitadas ..................................................... 108

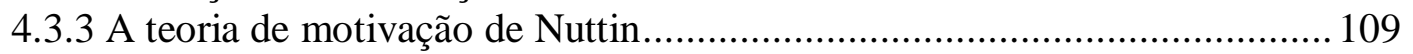

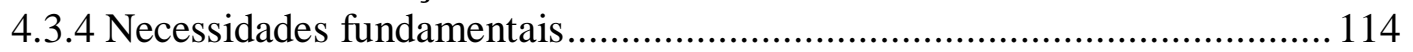

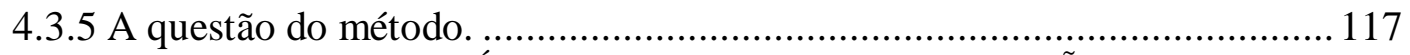

5. PROPOSTA DE UM MODELO TEÓRICO PARA ESTUDO DA MOTIVAÇÃO DE

VOLUNTÁRIOS E DA CULTURA DE ORGANIZAÇÕES DE TERCEIRO SETOR. ..........................119

5.1 Em busca da construção de um modelo teórico para o estudo da motivação ..... 119

5.1.1 Quanto ao conceito de motivação......................................................... 120

5.1.2 Sobredeterminação e complexidade dos motivos................................... 121

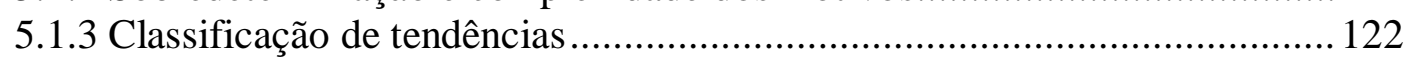

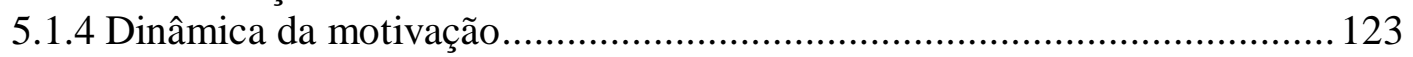

5.1.5 Metodologia de estudo da motivação. ................................................... 127

5.1.6 A superficialidade dos estudos sobre motivação de voluntários ................. 128 
5.2 Uma proposta de modelo de pesquisa de cultura para organizações de Terceiro Setor

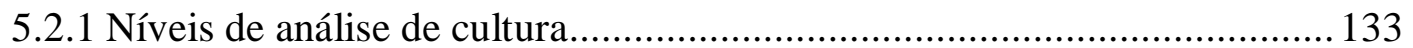

5.2.2 Análise cultural em nível de movimento político, religioso ou social ........ 135

5.2.3 Abertura da organização à comunidade e a outras esferas da sociedade..... 135

5.2.4 Análise da cultura organizacional....................................................... 136

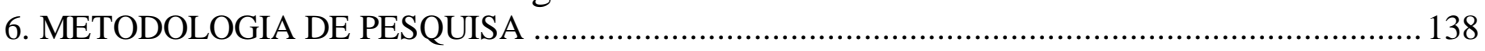

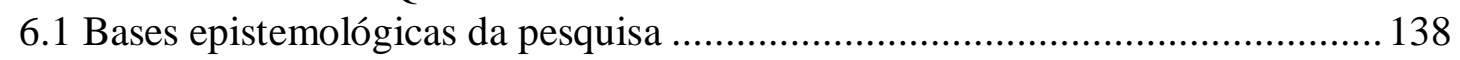

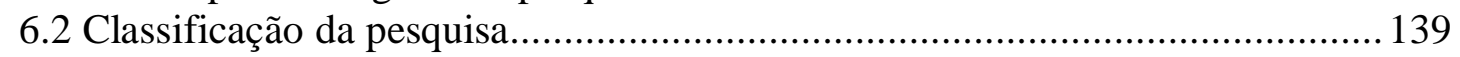

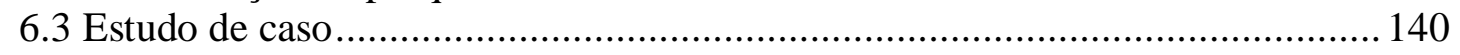

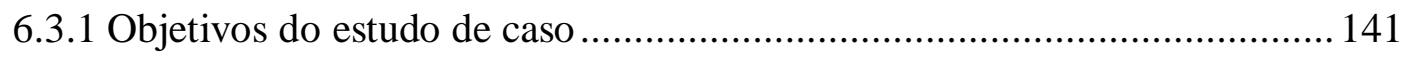

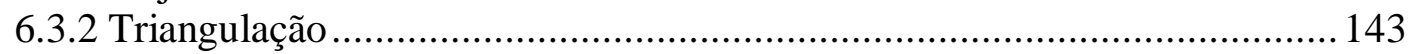

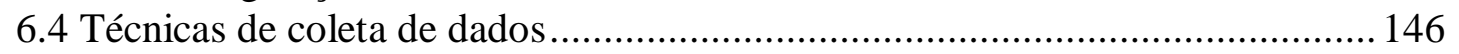

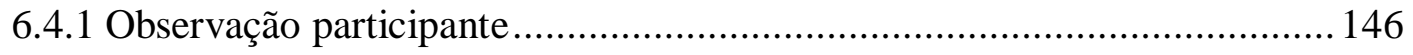

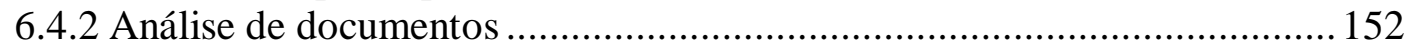

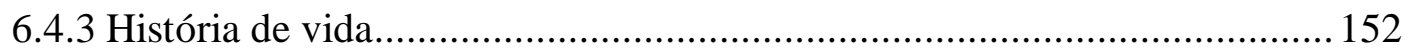

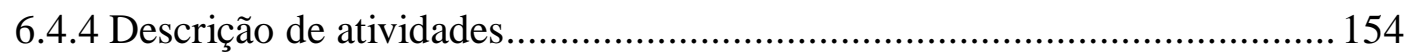

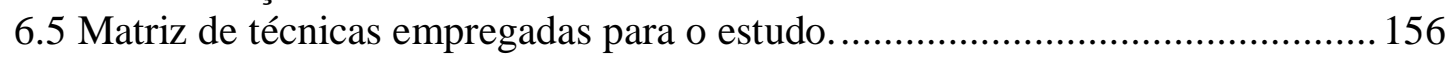

6.6 Limitações do estudo............................................................................ 157

7. OBRA SOCIAL ESPÍRITA: ETHOS E VISÃO DE MUNDO DO MOVIMENTO ESPÍRITA

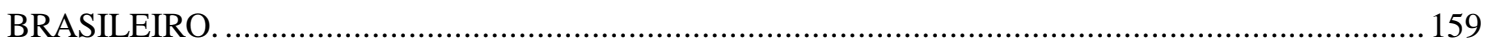

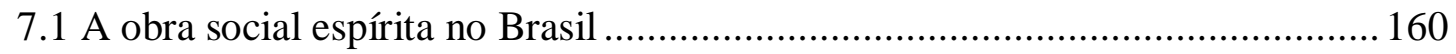

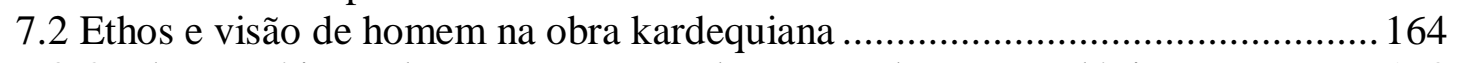

7.3 O ethos espírita, cultura e gestão em alguns estudos antropológicos.................. 170

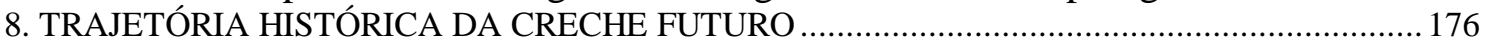

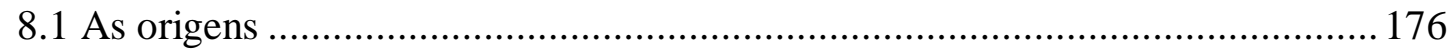

8.2 A preocupação inicial com recursos para a manutenção.................................. 179

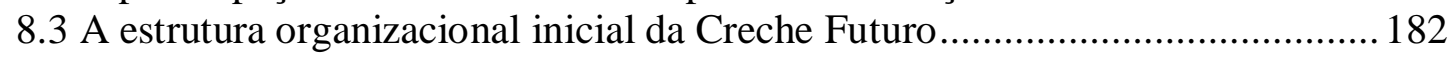

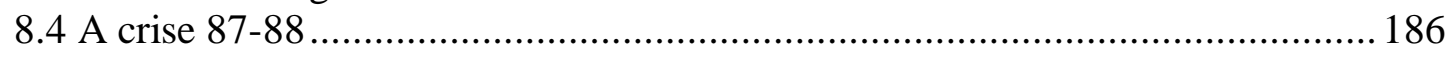

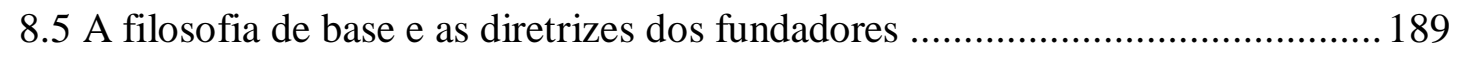

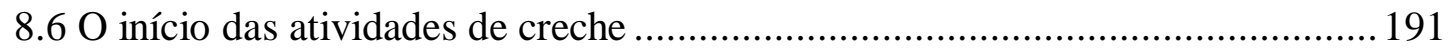

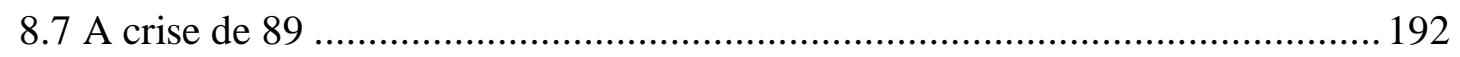

8.8 As relações (desiguais) com o poder público: a Prefeitura Municipal de Belo

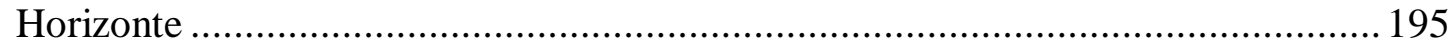

8.9 A história das qualificações da mantenedora e da creche................................. 198

8.10 A progressiva profissionalização e afastamento dos voluntários das atividades de

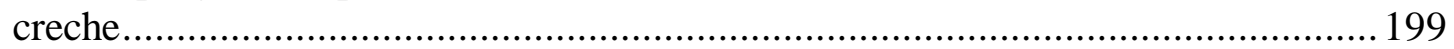

8.11 A nova estrutura organizacional de 1998 ....................................................2.200

9. ESTRUTURA, FUNCIONAMENTO E CULTURA ATUAIS DA CRECHE FUTURO .....................202

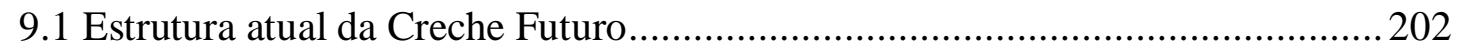

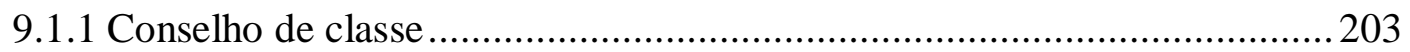

9.1.2 Superintendência e chefias de departamentos ......................................... 203

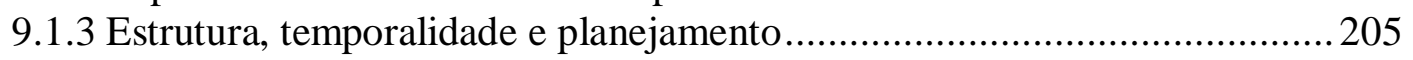

9.1.4 Atividades em curso e respectivas subordinações ...................................206

9.2 Recursos financeiros para manutenção da creche........................................... 209

9.3 Processos de comunicação na Creche Futuro ................................................ 211

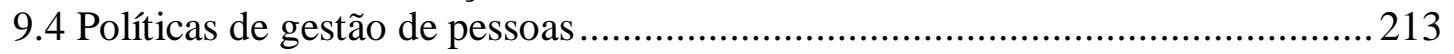

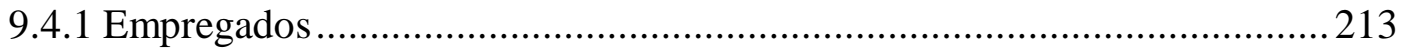

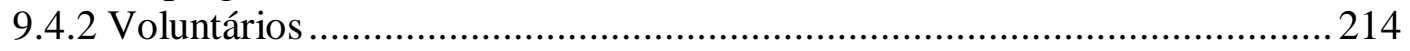




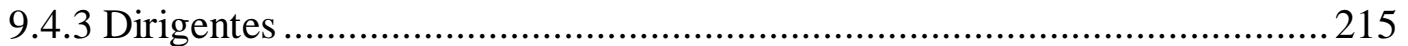

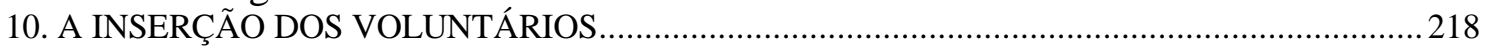

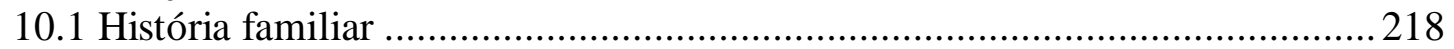

10.2 Trajetória anterior à Creche Futuro dos voluntários estudados. .....................220

10.3 Processo de atração e socialização na Creche Futuro...................................... 222

10.4 Significado de sua experiência ante um quadro de tendências motivacionais.. 224

10.5 Schemata identificados no discurso dos voluntários. ..................................222

10.6 O caráter paradoxal do trabalho voluntário: satisfação, desligamento e

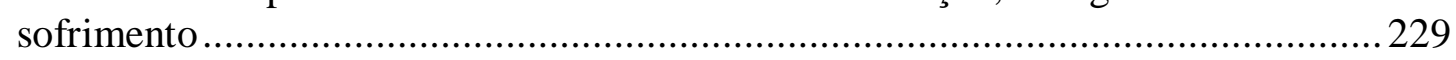

10.6.1 O trabalho voluntário como desligamento do sofrimento.......................229

10.6.2 O trabalho voluntário como fonte de sofrimento psíquico.......................231

10.6.3 Mecanismos de defesa empregados pelos voluntários contra o sofrimento.

11. DISCUSSÃO DOS RESULTADOS: EM BUSCA DE UMA ESPECIFICIDADE DAS

.233

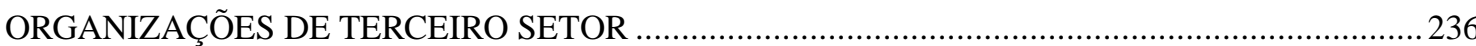

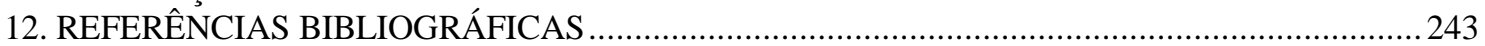

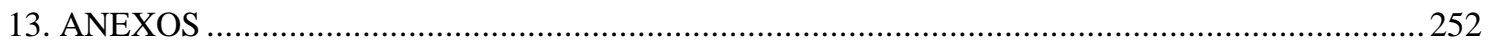

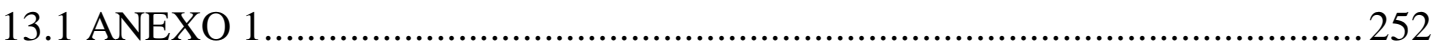

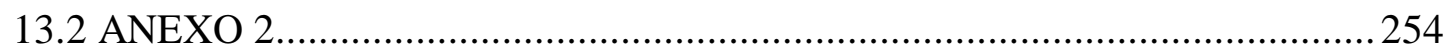




\section{INTRODUÇÃO}

Era um burrinho pedrês, miúdo e resignado, vindo de Passa-Tempo, Conceição do Serro, ou não sei onde no sertão. Chamava-se Sete-de-Ouros, e já fora tão bom, como outro não existiu e nem pode haver igual. - João Guimarães Rosa

A discussão de âmbito mundial sobre o papel e a agenda do Estado, associada a temas como a crise e reforma do Estado, descentralização e desconcentração, parceria e governança redefiniram os contornos das relações entre o Estado e o Terceiro Setor.

Analistas de renome passaram a considerar e destacar o papel do Terceiro Setor em seus esforços de entendimento e proposição de novos arranjos sociais. Claus Offe (1998), por exemplo, propôs um "mix cívico" composto de organizações do Estado, Mercado e Terceiro Setor como proposta para as contradições e conflitos das sociedades contemporâneas, onde nem um desses três tipos prevalecesse sobre os demais.

Autores como Martinelli (1997) retrataram o papel do Terceiro Setor em uma proposta que ganhou notoriedade em meio às empresas brasileiras: a de cidadania empresarial, que tem se concretizado em diferentes ações. Ele entende que a empresa não é apenas negócio, mas um ente intrinsecamente social, em uma relação de interdependência com diversos grupos de interesse.

Cardoso (1997) faz um paralelo entre a emergência da noção de terceiro mundo e a de Terceiro Setor, defendendo a ampliação de suas entidades constituintes para além das ONGs e incluindo as "instituições filantrópicas", as de "defesas de 
direitos de grupos específicos da população", as de "proteção ao meio ambiente" e as de “promoção de esporte, lazer e turismo".

Este tipo de contribuições modifica bastante o conceito tradicional de instituições filantrópicas, vigente na legislação brasileira, e o de organizações que não visam a lucro, posto que ampliam o papel, os objetivos e a relevância socioeconômica das organizações do Terceiro Setor, entendendo-as não apenas como "auxiliares voluntárias" do Estado e "beneficiárias de iniciativas empresariais louváveis", mas também incorpora-lhes papéis como os de lugar de participação e representação social, de parceiras na prestação de serviços de interesse social e de grupos de pressão.

A disseminação desse conceito deve influenciar a sociedade brasileira nos próximos anos, de forma que o amadurecimento e a consolidação das parcerias entre Terceiro Setor, Estado e Mercado, demandarão o desenvolvimento dos conhecimentos da gestão deste tipo de organização. No Brasil já se discute o papel do "gestor social", que se constituirá em uma nova especialização do administrador e trará contribuições para a informalidade e o improviso, que têm caracterizado os processos de gestão, especialmente das chamadas organizações filantrópicas.

O’Neill (1998) mostrou em seu trabalho como os programas de "nonprofit management education ${ }^{l}$ - NME" estão se consolidando nos Estados Unidos, onde já existem mais de 70 programas, geralmente em nível de pós-graduação, ligados a MBAs² e MPAs ${ }^{3}$.

Estas transformações têm gerado um aumento de produção de conhecimento sobre gestão de organizações de Terceiro Setor no Brasil, nos últimos anos. Encontra-se

\footnotetext{
${ }^{1}$ Educação gerencial para organizações "que não visam lucro".

${ }^{2}$ Master of Business Administration

${ }^{3}$ Master of Public Administration
} 
literatura disponível sobre administração geral de OTS (TENÓRIO, 1998, p.e.), conceito e papel das OTS (FISCHER, FALCONER, 1998, FISCHER, FALCONER, 2000 p. e.) direito administrativo (SZASI, 2000 p. e.), sobre planejamento e avaliação destas organizações (CHIANCA, MARINO, SCHIESARI, 2001; STERN, 2001 p. e.) e têm surgido inúmeros trabalhos que refletem sobre responsabilidade social e cidadania empresarial das empresas (TORRES, 2000; CEATS-USP, 1999 p. e.). Entretanto, a literatura encontrada, referente à motivação de voluntários e gestão de pessoas em OTS geralmente trata da realidade norte-americana e européia (SCHINDLER-RAINMAN, 1980; MCCURLEY, 1994, p. e.), ou é concebida de forma generalista ou ainda reduzida ao cumprimento das exigências da lei. Esta revisão inicial do tema sugere que as contribuições sobre esse assunto específico poderiam contribuir para o avanço do conhecimento nessa área.

Dois problemas de pesquisa são de importância central neste trabalho: Como ocorre a motivação de voluntários em uma organização brasileira do Terceiro Setor, prestadora de serviços? Que elementos da cultura organizacional devem ser considerados para o entendimento de uma organização de Terceiro Setor prestadora de serviços?

A primeira questão é tratada de forma sumária na literatura a esse respeito ${ }^{4}$. O presente trabalho analisará os dados colhidos em campo, com base em um modelo construído a partir da análise crítica de três diferentes teorias de motivação e em uso por autores contemporâneos.

A segunda questão tem sido analisada por autores de Administração e Ciências Sociais que estudam o Terceiro Setor, principalmente no que se refere à certa

\footnotetext{
${ }^{4}$ COELHO, 2000, MASCARENHAS, ZAMBALDI, 2002, por exemplo.
} 
constatação com ares de denúncia sobre a transferência de processos de gestão da iniciativa privada e do Estado para o Terceiro Setor, sem qualquer estudo que aponte para suas características distintivas.

Tenório (1999) critica os "profissionais desempregados e/ ou aposentados" dos outros setores que "levam suas tecnologias gerenciais de orientação estratégica para os espaços destinados à orientação dialógica" e defende que ele atue sob uma epistemologia diferente daquela do mercado, que seria "uma perspectiva dialógica, comunicativa, na qual suas ações devem ser implementadas por meio da intersubjetividade racional dos diferentes sujeitos sociais, a partir de esferas públicas em espaços organizados da sociedade civil". Ele conclama os pesquisadores deste tema a promoverem debates interdisciplinares, para referenciarem pesquisas, ensino e transferência de tecnologia que permitam a manutenção das OTS, como "agentes de solidariedade e justiça social".

A literatura administrativa voltada ao Terceiro Setor $^{5}$ parte de uma espécie de premissa não enunciada de que os agentes e organizações do Terceiro Setor desconhecem as técnicas de administração de empresas, que seu futuro passa pelo estabelecimento de parcerias com os demais setores para obtenção de recursos e pela "profissionalização" dos seus dirigentes e empregados. Geralmente esses autores se baseiam em análises da legislação e em estudos descritivos de seus programas, mas são mais raros os estudos sobre a lógica interna ${ }^{6}$ das organizações de Terceiro Setor. Aparentemente, o que se tem é uma expectativa das organizações de Mercado e do Estado em relação às OTS, que demanda ações não fazem partem da tradição dos seus

\footnotetext{
${ }^{5}$ TACHIZAWA, 2002, o próprio TENÓRIO, 1998, MELO NETO, FROES, 2001, por exemplo.

${ }^{6}$ GIUMBELLI, 1998, LANDIM, 1998, MARÇON, ESCRIVÃO FILHO, 2001 p. e.
} 
processos de gestão e que torna percebidas como mal instrumentalizadas pelas primeiras.

Para discutir-se essa questão, realizou-se um estudo de caso em uma organização de distribuição de bens e prestadora de serviços à comunidade, cujo nome verdadeiro foi substituído, por razões éticas, por "Creche Espírita Futuro" ou, simplesmente, "Creche Futuro".

O conteúdo da tese foi desenvolvido em dez capítulos, aos quais se adicionam esta introdução, a lista de referências bibliográficas e os anexos, além dos elementos pré-textuais.

O segundo capítulo tem como objetivos esclarecer o conceito de Terceiro Setor, propor um modelo de classificação das organizações que o compõem, relacionar as razões de sua emergência e apresentar alguns pontos centrais da legislação brasileira sobre esse setor.

O terceiro capítulo faz um roteiro breve do desenvolvimento dos estudos de cultura organizacional, detendo-se um pouco nos trabalhos de Geertz, Hofstede, Schein e Fleury, que foram a base para o desenvolvimento do modelo teórico que permitiu a análise cultural da organização em análise.

O quarto capítulo não só situa o leitor na complexidade dos estudos sobre motivação em psicologia do trabalho e organizacional, como apresenta a releitura de três autores considerados importantes para campo do conhecimento: Maslow, McClelland e Nuttin.

O quinto capítulo é a proposta de modelo de estudo de organizações de Terceiro Setor, que privilegia os dois temas anteriormente revistos e que articula, 
criticamente, os diferentes autores estudados. Esse capítulo foi utilizado como base teórica para a análise do caso, que, também, lhe fez acréscimos e revisões.

O sexto capítulo apresenta e justifica as escolhas epistemológicas e metodológicas feitas para a presente pesquisa e mostra como esta se desenvolveu, os cuidados tomados para a sua realização e os limites contingentes a essas escolhas.

Os dois capítulos subseqüentes apresentam o ethos espírita na obra kardequiana e nos estudos realizados por antropólogos, entendidos como fundamentos para a compreensão da Creche Espírita Futuro. Segue-se a apresentação da sua história, de suas crises, de suas principais mudanças de estrutura organizacional e de sua parceria com a Prefeitura de Belo Horizonte. Esta análise cultural levanta os primeiros elementos que permitem o entendimento da inserção, socialização e "migração" dos voluntários dentro dessa organização.

O nono capítulo é um estudo transversal dos principais processos de gestão da creche à época da pesquisa (2002-2003), o qual pode ser interpretado com significação mais ampla e singular, graças ao conhecimento histórico e cultural anteriormente empreendido.

O capítulo 10 desloca o objeto de análise para os voluntários de um dos territórios da Creche e para o seu discurso, obtido por meio de entrevistas feitas pelo pesquisador. Esse capítulo tem por objetivo desvelar a dinâmica motivacional e mostrar como indivíduos diferentes, em um mesmo espaço organizacional, transitam por diferentes atividades até se sentirem mais confortáveis. As entrevistas sugerem a existência de sujeitos com perfis de motivação muito diferentes entre si, com histórias familiares e institucionais variadas, vivendo a situação paradoxal, mas muito significativa para eles de prazer, de desligamento de conflitos e de sofrimento. 
O capítulo de conclusão é um retorno sintético às questões de pesquisa e uma visão panorâmica das contribuições desta tese, uma vez que as propostas de novos estudos foram inseridas nos capítulos anteriores à medida que se iam discutindo os resultados obtidos. 


\title{
2. O TERCEIRO SETOR COMO OBJETO DA TEORIA ADMINISTRATIVA
}

\begin{abstract}
Vinha-lhe de padrinho jogador de truque a última intitulação, de baralho, de manilha; mas, vida a fora, por amos e anos, outras tivera, sempre involuntariamente. Brinquinho, primeiro, ao ser brinquedo de meninos, Rolete, em seguida, pois fora gordo, na adolescência; mais tarde, ChicoChato, porque o sétimo dono, que tinha essa alcunha, se esquecera, ao negociá-lo, de ensinar ao novo comprador o nome do animal, e, na região, em tais casos, assim sucedia; e, ainda, Capricho, visto que o novo proprietário pensava que Chico-Chato não fosse um apelido decente. - João Guimarães Rosa
\end{abstract}

Antes de se pensar em produção de conhecimento administrativo para o

Terceiro Setor, é fundamental demarcar-lhe com alguma precisão, o objeto de estudo e a singularidade ante os outros tipos de organização com tradição em pesquisa: as organizações de mercado e as organizações públicas.

\subsection{Sobre o conceito de Terceiro Setor}

Terceiro Setor é o termo que identifica organizações da sociedade civil, que se distinguem das organizações do Mercado e do Estado. Ele tem sido objeto de estudos e contribuições cada vez mais expressivas.

Dois elementos são indispensáveis para distinguir as organizações dos demais setores: elas não visam a lucro (característica das organizações de mercado), nem são dirigidas por qualquer uma das instâncias do Estado, embora possam formalizar parcerias com organizações do Estado ou Mercado. Esta distinção, entretanto, não é suficiente, uma vez que não se define um termo ou conceito, a partir da 
exclusão de outros significados. (COELHO, 2000. p. 62. FISCHER, R., FALCONER, A., 1998. p. 13.)

Uma delimitação de Terceiro Setor muito influente nos estudos brasileiros é a de Salamon (1997), que, pesquisando essas organizações na Universidade Johns Hopkins, destacou as seguintes características: não-governamentais, não visam à distribuição de lucros, têm alto grau de autogerenciamento e nível significativo de participação voluntária.

Não se confunde Terceiro Setor com setor terciário da economia. Coelho (2000, p. 58) distingue esses dois termos, uma vez que o segundo diz respeito a organizações do Mercado ou Estado (administração indireta), geralmente relacionadas a comércio e prestação de serviços.

Nota-se, atualmente, uma tentativa cada vez maior de se empregar o termo "sociedade civil"7 para designar as organizações do Terceiro Setor. Entretanto, a substituição de "organizações do Terceiro Setor" por "organizações da sociedade civil" (OSC) dificilmente resiste a uma análise semântica ou histórica.

Bobbio (1982) fez uma recuperação do conceito de sociedade civil no pensamento político, visando a uma análise da obra gramsciana ${ }^{8}$. Para tanto, ele apresentou a trajetória do conceito pelas principais correntes da filosofia que influenciaram as ciências políticas até Hegel. Segundo este autor de renome na ciência política, o conceito de sociedade civil se opõe ao de sociedade natural para os jusnaturalistas, confundindo-se com (ou, melhor dizendo, incorporando em seu significado) a sociedade política ou estado. O mesmo se dá em Hegel, por razões um

\footnotetext{
${ }^{7}$ Cf. LANDIM, 1999, p. 8, FALCONER, VILELA, 2001, p. 28, FERNANDES, 1997, TANDON, 1991.

${ }^{8}$ Gramsci tem sido uma das principais referências dos autores contemporâneos que pretendem empregar o conceito de sociedade civil como sinônimo de Terceiro Setor.
} 
pouco diferentes. Ao contrapor-se a Hegel, Marx emprega o conceito de sociedade civil articulando-o à noção de estrutura, ou seja, inclui nele "todo o conjunto de relações materiais". Desta forma ele insere, nesse conceito, as organizações de mercado. Gramsci não se afasta desse recorte, ao opor sociedade civil a sociedade política ou estado. O que se constata, portanto, é que o conceito de sociedade civil, em alguns autores, engloba o conceito de estado; em outros engloba o conceito de empresa e, em nenhum dos que foram revistos, se acha distinto das noções de Estado ou Mercado. Por esta razão, considerou-se neste trabalho que o termo "organizações da sociedade civil" não substitui com clareza e precisão semântica a expressão “Terceiro Setor”.

O conceito de "Terceiro Setor" foi bem revisto por Alves (2002), que remontou sua origem a um trabalho de Etzioni, publicado em 1972, no qual ele defendia o repasse de recursos governamentais para essas organizações. Ele promove uma discussão dos conceitos alternativos para "Terceiro Setor”, a saber: organizações não governamentais (ONG), economia social, setor voluntário, setor independente ${ }^{9}$, filantropia ou setor filantrópico e setor de caridade. Além das expressões revistas por este autor, como foi visto, vem sendo utilizada também a expressão "organizações da sociedade civil".

De todos os termos revistos, o que se mostra mais preciso, porém, é o primeiro, que será utilizado nesta tese.

\footnotetext{
${ }^{9}$ Para uma leitura rápida sobre a origem do termo setor independente, ver MULHARE, 1999, p. 325.
} 
2.2 Pessoas jurídicas integrantes do Terceiro Setor no Brasil

Szazi (2000) desenvolveu um trabalho em que mostra existirem basicamente dois tipos de pessoas jurídicas, sob as quais se encontram as organizações que compõem o chamado Terceiro Setor.

O primeiro tipo refere-se às associações, que podem ser definidas como "pessoa jurídica criada a partir da união de idéias e esforços de pessoas em torno de um propósito que não tenha finalidade lucrativa”. (SZAZI, 2000. p. 27) As associações possuem patrimônio, mas não dividem o resultado entre os sócios. Elas podem perceber contribuições para fins "culturais, educacionais, esportivos, religiosos, recreativos e morais."

O segundo tipo de pessoa jurídica refere-se às fundações, definidas pelo autor como "patrimônio destinado a servir, sem intuito de lucro, a uma causa de interesse público determinada, que adquire personificação jurídica por iniciativa de seu instituidor". (SZAZI, 2000. p. 38) Essa modalidade de pessoa jurídica pode ser de direito público ou de direito privado, e é caracterizada, como se pode ver, pela destinação de bens à consecução de fins sociais, determinados pelo fundador.

A legislação brasileira beneficia alguns tipos de associação com vantagens fiscais, como a imunidade e a isenção. Para este fim, Szazi distingue as associações que possuem cunho social (promovem atividades que seriam função do Estado para o proveito de todos) das que possuem apenas o chamado cunho associativo (que existem para divulgação de interesses particulares dos associados). Apenas as primeiras são contempladas com vantagens fiscais. Coelho (2000) mantém a mesma distinção com termos diferentes. Esta autora distingue "fins coletivos" de "fins públicos". As associações, com fins meramente coletivos, promoveriam ações de interesse grupal 
(grupos de filatelistas, por exemplo), enquanto as outras promoveriam ações de interesse geral da sociedade, seja prestando serviços públicos, seja advogando direitos para os cidadãos em geral, ou grupos de pessoas que não fazem parte da associação.

Esta distinção é importante para a decisão sobre a concessão "utilidade pública" e para fins de classificação interna das diferentes organizações que compõem o Terceiro Setor. Com base nessas considerações, neste estudo não se reduz o conceito de Terceiro Setor ao jargão "público-não-estatal", muito difundido no Brasil. Considerar a finalidade pública como um elemento essencial do Terceiro Setor gera inúmeros problemas de delimitação, como se lê em Melo, Fischer, Soares Júnior (2003).

\subsection{A emergência do Terceiro Setor}

Há uma divergência acentuada entre os autores sobre as origens e as razões do interesse nas organizações de Terceiro Setor nas últimas décadas. Para o presente trabalho apresentar-se-á um conjunto dessas razões, sem hierarquias ou reduções.

Com relação ao Estado:

a) O Terceiro Setor se tornou uma alternativa para uma reforma do estado que o pretenda tornar promotor, mais que realizador, de ações sociais;

b) Como consequiência da afirmativa anterior, na realidade brasileira, as organizações de Terceiro Setor se tornaram uma alternativa legal de terceirização de mão-de-obra e de contratação de pessoas para a consecução dos objetivos do Estado pela Consolidação das Leis do Trabalho, e, portanto, com maior precariedade de vínculo empregatício e com menores encargos previdenciários;

c) Ainda como conseqüência da primeira afirmativa, as organizações de Terceiro Setor se tornaram uma alternativa legal e mais rápida para a contratação de serviços e 
rescisão de contratos, permitindo ao administrador público maior arbítrio, com menor interferência do Poder Legislativo, no dimensionamento dos serviços que o Poder Executivo deve e deseja prestar à sociedade;

d) A capacidade de inserção comunitária de algumas organizações de Terceiro Setor tem despertado interesse de agentes do Estado;

e) As mudanças políticas nos governos socialistas autoritários levaram a Europa e os pensadores de esquerda a refletirem sobre o papel das comunidades e dos interesses locais para a construção de políticas sociais;

f) No plano internacional, as chamadas organizações não-governamentais, assim designadas pela Organização das Nações Unidas, ganharam notoriedade pública e espaços para execução de políticas internacionais.

Com relação às empresas:

a) O Terceiro Setor se tornou uma alternativa para a implementação de ações de responsabilidade social pelas empresas;

b) O Terceiro Setor se tornou uma alternativa para o marketing societário das organizações de mercado;

c) O Terceiro Setor é um parceiro potencial para as empresas de grande porte realizarem ações de cunho social, empregando incentivos fiscais, ou destinarem parte do imposto de renda devido;

d) $\mathrm{O}$ Terceiro Setor passou a ser percebido como um ator importante junto às comunidades onde atuam, o que despertou o interesse de empresas que passaram a valorizar os chamados stakeholders ${ }^{10}$ da organização;

\footnotetext{
${ }^{10}$ Do inglês "depositário de aposta", utilizado para referir-se a públicos da organização que são afetados por suas ações, como clientes, fornecedores, parceiros, empregados e comunidade. O termo tem sido
} 
e) O Terceiro Setor tornou-se um parceiro potencial para a implementação de estratégias empresariais (PORTER, 2003);

f) A gravidade dos problemas sociais brasileiros tem chamado a atenção de sócios e administradores de empresas, que desejam influenciar no cenário social de forma efetiva. O Terceiro Setor é uma alternativa às instituições do Estado, para esses homens de empresa.

Com relação às universidades:

a) Têm sido criados cursos na graduação e pós-graduação em Administração, relacionados ao Terceiro Setor;

b) Nos últimos anos tem havido a promoção de eventos acadêmicos como congressos e seminários relacionados à gestão do Terceiro Setor;

c) Há grupos de pesquisa formados que produzem trabalhos sobre gestão de organizações de Terceiro Setor;

d) O fortalecimento e a profissionalização de algumas organizações de Terceiro Setor geraram uma nova possibilidade de carreira profissional, que atrai a atenção de alunos e profissionais.

Com relação às organizações sem fins lucrativos:

a) Foram criadas no Brasil e no exterior redes e organizações com a finalidade de consolidar e desenvolver as OTS;

b) Alguns atores sociais do Terceiro Setor passaram a demandar dos meios acadêmico e social espaços e propostas para os auxiliarem a solucionar alguns dos problemas existentes (antigos e novos) em suas organizações;

empregado como alternativa a uma linha de pensamento administrativo que apenas considera os interesses dos acionistas (shareholders, em inglês) para fins de decisão. 
c) $\mathrm{O}$ aumento de possibilidades de parcerias com o Estado e o Mercado criou demandas para as organizações de Terceiro Setor, como a necessidade de avaliação de resultados e de impacto de suas ações, de celebração de contratos e outros instrumentos jurídicos, de prospecção de fontes de recursos, que as organizações não estavam acostumadas a atender;

d) A ascensão de governos de orientação social democrática ou socialista no Brasil possibilitou a organizações reivindicatórias sem fins lucrativos concretizarem projetos com o auxílio do Estado;

e) Novas leis e decretos no Brasil vêm influenciando as organizações de Terceiro Setor e a ação do Estado vem exigindo mudanças para as quais as organizações não se prepararam com antecedência.

2.4 A questão da identidade e classificação das organizações do Terceiro Setor

O debate sobre a identidade do Terceiro Setor ainda está longe de se esgotar, especialmente porque esse conceito compreende organizações com diferenças marcantes do ponto de vista de atuação social e orientação política.

Landin $(1998,1999)$ realizou pesquisas sistemáticas e deparou-se com os impasses de ter que lidar com um universo composto por entidades de origem política, ligadas a lutas sociais e entidades religiosas, voltadas à prática da assistência e da caridade. Este mal-estar ainda se encontra vivo e ativo nas discussões sobre a importância de se empregar uma categoria que contemple organizações tão diferentes que não desejam ser identificadas como semelhantes a outras componentes do mesmo segmento. 
As diferenças internas das organizações componentes do Terceiro Setor não são impedimento em si para sua análise como um todo, dada a existência de elementos comuns. Há diferentes organizações compondo o Estado e o Mercado. Se se considerar a personalidade jurídica, por exemplo, são componentes do conceito de Estado os órgãos de administração direta e indireta, sendo que na última se encontram empresas públicas, sociedades de economia mista, autarquias e fundações. Se se comparar uma sociedade de economia mista a um órgão da administração direta, os contrastes são flagrantes, seja no regime de contratação de pessoal, seja no interesse de distribuição de lucros dos sócios, seja nos procedimentos contábeis e de gestão, mas essas diferenças não geram dúvidas aos estudiosos de administração no que concerne à validade do conceito de Estado como setor que abarque tão diferentes organismos. Isso ocorre da mesma forma com a categoria mercado.

Não há de ser pela existência de diferenças entre as organizações que se inviabilizará sejam estudadas sob uma só designação, desde que haja um sistema classificatório que permita distinguir suas peculiaridades e que haja fenômenos comuns e gerais, próprios deste grupo de organizações como um todo. Entende-se que a criação de organizações em torno do princípio da "não-lucratividade", comum a todas elas, impõe de alguma forma a existência desses fenômenos sociais e grupais comuns, no contexto de uma teoria da ação social, por exemplo, mas este é um tema cujo desenvolvimento foge aos objetivos desta tese.

Outro elemento comum a elas, que não passou despercebido a Kurz (1997), reside na existência de "visões de mundo e de homem" substantivas e constitutivas de sua cultura. Os membros das organizações costumam ser igualmente membros de movimentos políticos, religiosos e sociais, o que permite dizer que a cultura é um foco 
privilegiado que confere uma identidade comum a um setor tão díspar, do ponto de vista das idéias diretrizes dos movimentos referidos.

Essa discussão sobre a identidade das organizações de Terceiro Setor remete à necessidade de lançar luz sobre as singularidades de seus segmentos. Alguns modelos de classificação já foram propostos na literatura, na sua maioria direcionados pela atividade principal realizada pela OTS, como o de Scherer, Warren e Gohn, apresentado por Coelho (2000, p. 63) que distingue as ONG em caritativas, desenvolvimentistas, cidadãs e ambientalistas. Esta classificação, entretanto, incorre no problema de se manter como designação geral o termo organização não-governamental, que define por exclusão, como argumenta Coelho (2000, p. 65). A autora também observou, a partir de sua pesquisa, que grande número das entidades assistenciais brasileiras não se percebem como ONG, reconhecendo-se, entretanto, como Organização de Terceiro Setor, ainda que sem entender tal conceito com precisão. O maior óbice deste tipo de classificação é a superficialidade das categorias, que não apontam para distinções de fenômenos organizacionais, mas apenas para distinções de atividades-fim declaradas.

Outra proposta de alcance internacional foi a adotada por Landim (1999), denominada International Classification of Nonprofit Organizations - ICNPO. Ela “classifica os elementos pelos serviços e bens que produzem" e é composta por doze itens:

1. cultura e recreação

2. educação e pesquisa

3. saúde

4. assistência social

5. ambientalismo 
6. desenvolvimento

7. defesa de direitos civis e advocacy

8. filantrópicas - intermediárias no financiamento de projetos ou promoção de voluntariado

9. internacionais

10. religiosas

11. associações profissionais e sindicatos

12. outras

Buscando uma categorização mais substantiva e ancorada teoricamente, esta pesquisa baseou-se no trabalho de Azevedo e Prates (1991) em que se distingue a ação social como de distribuição de bens e prestação de serviços, da ação social que tem em vista a definição de políticas. Este trabalho originalmente foi escrito para o entendimento de movimentos sociais e, por fundamentar-se em uma teoria da ação social, pode ser estendido, com vantagens analíticas, para a compreensão das similitudes e diferenças entre as diversas organizações que compõem o Terceiro Setor.

Com base neste trabalho e considerando-se as atividades-fim das OTS e suas organizações, construiu-se a classificação que se segue: 


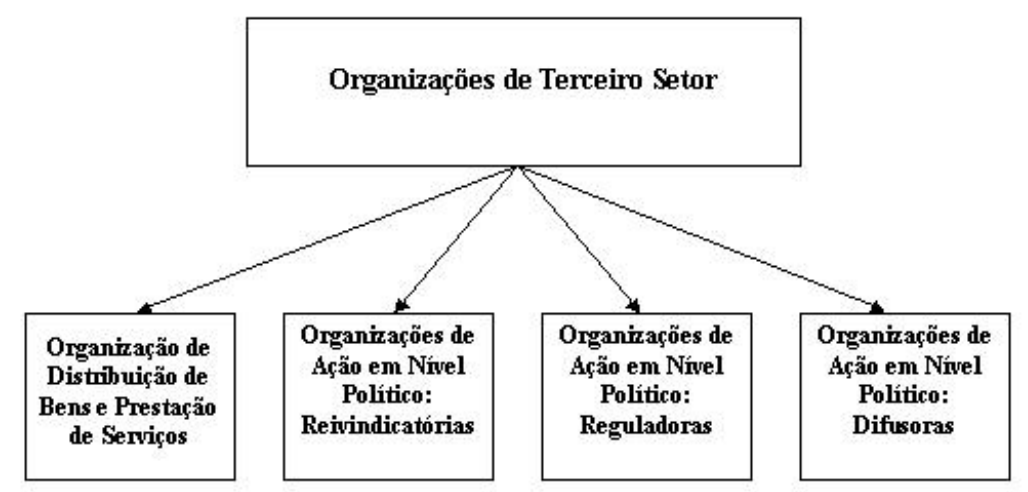

Figura 1: Classificação das organizações de Terceiro Setor

Neste referencial, tanto as organizações de fins caritativos, como uma creche mantida por igreja, quanto uma organização de serviços mantida por um partido político ou em formato de organização social, como é o caso do Hospital das Pioneiras Sociais (organização social mantida por contrato de gestão pelo Governo Federal) seriam classificados na primeira categoria.

Esta categoria contempla igualmente o conceito de grantmaker $^{11}$, difundido no Brasil pelo trabalho de Falconer e Vilela (2001) e definido por eles como organizações de Terceiro Setor autônomas, que captam e oferecem recursos para outras organizações sem fins lucrativos.

\footnotetext{
${ }^{11} \mathrm{O}$ verbo da língua inglesa to grant possui muitos significados, dentre eles: doar, transferir propriedade, conceder, outorgar. Em sua acepção ampla, ele envolve a concessão de direitos ou privilégios, recursos financeiros ou bens. Grantmaker seria a pessoa física ou jurídica que realiza estas concessões, não tendo em seu sentido original o caráter de organização de Terceiro Setor.
} 
A segunda categoria compreende organizações institucionalizadas, como a ambientalista "SOS Mata Atlântica", mas não envolve movimentos sociais, como o Movimento dos Trabalhadores Rurais sem Terra. O conceito de Terceiro Setor, em uso, abrange apenas organizações com personalidade jurídica.

A terceira categoria seria composta por associações da sociedade civil às quais o Estado, o Mercado ou a Sociedade concedessem poder regulador, como é o caso da Social Accountability International - SAI, ex-Council on Economic Priorities Acreditation Agency - CEPAA, que criou e tem mantido o Social Accountability 8000, um selo certificador para as empresas que atendam às exigências propostas, referentes à qualidade de conduta do ambiente de trabalho, com parâmetros fixados por especialistas internacionais de direitos humanos.

Por fim, há as organizações de Terceiro Setor cujo objetivo principal é a disseminação de políticas e práticas de interesse social. Um bom exemplo desta categoria é a Fundação ABRINQ, que vem difundindo políticas de proteção à infância e à adolescência.

Essa classificação não é mutuamente exclusiva, uma vez que uma OTS pode desenvolver diversas atividades identificadas com diferentes categorias. De uma forma geral, busca-se identificar a atividade nuclear da organização, que estaria associada ao desenvolvimento de competências próprias por parte de seus membros para a consecução eficaz dos objetivos. Sugere-se que a OTS seja classificada pela atividade mais identificada com a sua missão e imagem, assim como pela análise da complexidade das atividades realizadas por ela. 
Dada à complexidade do setor, o presente trabalho se voltará à análise da gestão de voluntários de uma organização de distribuição de bens e prestação de serviços: a Creche Espírita Futuro (nome fictício).

\subsection{Regulamentação do Terceiro Setor no Brasil}

A legislação brasileira se pronuncia de forma geral com relação às organizações de Terceiro Setor com relação a três grandes temas: suas características e instituição, suas relações com o Estado, especialmente tributárias, e as relações de trabalho em seu contexto. Recentemente têm sido objeto de discussão e regulamentação, por parte do poder legislativo dos três níveis, as relações de parceria entre Estado e associações da sociedade civil.

A base para a manutenção do status de associação sem fins lucrativos repousa sobre algumas exigências referentes à gestão e, principalmente, à nãoremuneração ou distribuição de "vantagens ou benefícios por qualquer forma ou título em razão das competências, funções ou atividades atribuídas pelo estatuto social" a diretores, sócios, instituidores, benfeitores ou equivalentes. As organizações de Terceiro Setor podem contratar pessoas para a realização de suas atividades. Szazi afirma que:

\footnotetext{
“...não perde a categoria de associação mesmo que realize negócios para manter ou aumentar o seu patrimônio, sem, contudo proporcionar ganhos aos associados." (SZAZI, 2000, p. 27-28)
}

O artigo 150, inciso VI da Constituição veda à União, Estados, Distrito Federal e Municípios instituir imposto sobre "templos de qualquer culto", "patrimônio, renda ou serviços dos partidos políticos, inclusive suas fundações, das entidades 
sindicais dos trabalhadores, das instituições de educação e de assistência social, sem fins lucrativos, atendidos os requisitos da lei".

O mesmo texto de lei explica mais à frente que se trata das atividades essenciais das entidades do inciso c (todas as supracitadas exceto os templos religiosos).

Uma vez estabelecido o cunho social da organização de Terceiro Setor, esta associação ou fundação caracteriza-se como imune de impostos ou isenta de diversas contribuições e taxas, devendo, porém, recolher algumas.

Do ponto de vista trabalhista, ficou reconhecido o trabalho voluntário pela lei 9608/98, como qualquer “Atividade não remunerada prestada por pessoa física a entidade pública de qualquer natureza ou a instituição privada de fins não lucrativos com objetivos cívicos, culturais, educacionais, científicos, recreativos ou de assistência social, inclusive mutualidade". Esta lei exige que se assine um termo de adesão, que identifique o prestador e o tomador de serviços, apresente a natureza do serviço e as condições para o exercício (carga horária, local, material de apoio e afins).

Szazi (2000) afirma, com base no texto da lei, não apenas que o trabalho voluntário não pode ser exigido como contrapartida pela prestação de benefícios para o trabalhador ou algum membro de sua família, como também que ele é gratuito e deve ser prestado por pessoa física (e não por alguma organização).

Esses cuidados são fundamentais para que as organizações de Terceiro Setor evitem ações trabalhistas voltadas ao reconhecimento de vínculo empregatício e suas conseqüências.

Os empregados regulares de uma OTS seguem as disposições da Consolidação das Leis do Trabalho - CLT e algumas medidas preventivas devem ser tomadas para com os prestadores de serviços. 
Não se pretendeu com esses itens esgotar as implicações legais do tema, mas traçar um esboço geral que permita que se caracterizem os contornos jurídicos das OTS na realidade brasileira.

Resumindo, optou-se, portanto, pelo termo "Terceiro Setor" e pela expressão “organizações de Terceiro Setor" (OTS) para classificar o entorno do objeto de estudo da presente tese, em função da maior precisão deste termo e da sua originalidade, ou seja, não foi empregado anteriormente por autores de ciências humanas e sociais com outro sentido. Neste estudo, o termo Terceiro Setor significa o conjunto das organizações sem fins lucrativos, autogerenciadas, integrantes da sociedade civil, com finalidade pública ou coletiva. Propôs-se um modelo de classificação das organizações deste segmento o qual possibilita ao pesquisador se orientar dentro da diversidade de suas componentes e levantaram-se, de forma muito geral, as principais exigências do legislador brasileiro, bem como os benefícios concedidos por ele a esse grupo de organizações. 


\section{DISCUTINDO CULTURA NO NÍVEL DAS ORGANIZAÇÕES.}

É a quarta ou quinta vez que indica lugares malassombrados. Já sei: todo pau-d'óleo; todas as cruzes; todos os pontos onde os levadores de defunto, por qualquer causa, fizeram estância, depondo o esquife no chão; todas as encruzilhadas - mas somente à meia noite; todos os caminhos: na quaresma - com os lobisomens e as mulas-sem-cabeça, e o cramondongue, que é um carro-de-bois que roda à disparada, sem precisar de boi nenhum para puxar. João Guimarães Rosa

O termo cultura não surgiu originalmente no seio da teoria administrativa, pelo contrário, é um termo bastante antigo. $\mathrm{Na}$ sociedade romana, a palavra latina colere referia-se ao cultivo de produtos relacionados com a terra, a educação, o desenvolvimento da infância e o cuidado com os deuses. Este significado foi sendo modificado ao longo dos anos, mas algumas das idéias permanecem até hoje.

\subsection{A cultura na Antropologia de Geertz.}

Clifford Geertz é um dos antropólogos que fez a ponte entre o estudo da cultura e as ciências humanas e sociais em geral. Criticando os pressupostos de uma certa sociologia estruturalista, o autor não se refere à cultura como um molde das condutas humanas, mas aceita-a como mapa ou como referências externas que permitem ao homem a construção de significantes simbólicos a partir dos quais ele se "completa" e se torna candidato a membro dos grupos sociais, aos quais se encontra vinculado.

Sua definição de cultura é:

“... um padrão de significados transmitidos historicamente, incorporado em símbolos, um sistema de concepções herdadas expressas em formas simbólicas por meio das quais os homens comunicam, perpetuam e desenvolvem seu conhecimento e suas atividades em relação à vida." (GEERTZ, 1989, p. 66) 
Seu trabalho foi construído dentro dos pressupostos da pesquisa etnográfica, não com o objetivo empirista de reduzir e prever, mas de compreender de forma complexa, mas inteligível e racional, o significado do diferente, do inusitado.

Ele se propôs a estudar fenômenos sociais como a religião, a ideologia e a política como sistemas culturais. Para tal empreitada, Geertz analisou os aspectos morais e estéticos (ethos) e os aspectos cognitivos (visão de mundo) com os quais um sistema cultural permite a seus membros interpretar sua experiência e organizar sua cultura. Nesta análise, ele se atém aos símbolos, que são o que ele metaforiza como um "armazém de significados".

\footnotetext{
“...os símbolos sagrados relacionam uma ontologia e uma cosmologia com uma estética e uma moralidade: seu poder peculiar provém de sua suposta capacidade de identificar o fato com o valor no seu nível mais fundamental, de dar um sentido normativo abrangente àquilo que, de outra forma, seria apenas real." (GEERTZ, 1989, p. 93-94)
}

Assim, ele se refere aos sistemas religiosos, por exemplo, como um "conjunto de símbolos sagrados, tecido numa espécie de todo ordenado". A religião é percebida pelos seus adeptos como mediadora de um conhecimento genuíno. Os símbolos "dramatizam" valores positivos e negativos. Geertz entende que há uma dinâmica dos membros do sistema religioso que faz com que eles tendam a desejar uma espécie de "base factual" para o compromisso entre a rede de significados e a realidade. Isto faz com que as pessoas não se satisfaçam com um mero convencionalismo religioso.

Qual é o papel do antropólogo e da ciência, nesse contexto? Para o autor, eles devem estudar os valores, com vistas ao esclarecimento dos "processos essenciais envolvidos na regulação normativa do comportamento". 
Ele deseja que o cientista estude os valores reais, em sociedades reais, vivendo em termos culturais reais, procurando estímulo e validade, o que permite uma compreensão de como esses valores atuam.

Da Antropologia à Administração, que se define como uma ciência social aplicada, tem-se uma trajetória importante que se pretende apontar de forma sucinta.

3.2 Os estudos transnacionais e transregionais

O conceito de cultura foi trazido às ciências administrativas no final da década de 50. Muitos eventos justificam esse interesse, como a expansão geográfica das empresas multinacionais, que pretendiam reproduzir suas estruturas em outros países, para obter vantagens comparativas (mão de obra barata, novos mercados, proximidade a matérias primas, entre outras). Mesmo reproduzindo as estruturas e os principais programas, os resultados não são os mesmos e os administradores se deparam com problemas que não havia em seus países de origem. Dessa forma, uma das primeiras concepções de cultura empregada pela Administração é semelhante à concepção das culturas nacionais, segundo a qual se procura identificar que elementos culturais foram "obtidos" na sociedade pelos empregados, especialmente os que entram em conflito com a ordem original, para se buscar novo arranjo organizacional ou a mudança de crenças e valores dos empregados.

Smircich (1983) representou esta linha de estudos da cultura nas organizações a partir da figura seguinte. Nela, cada membro da organização ( simbolizado como um círculo) é visto como portador da cultura obtida em um contexto cultural externo. 


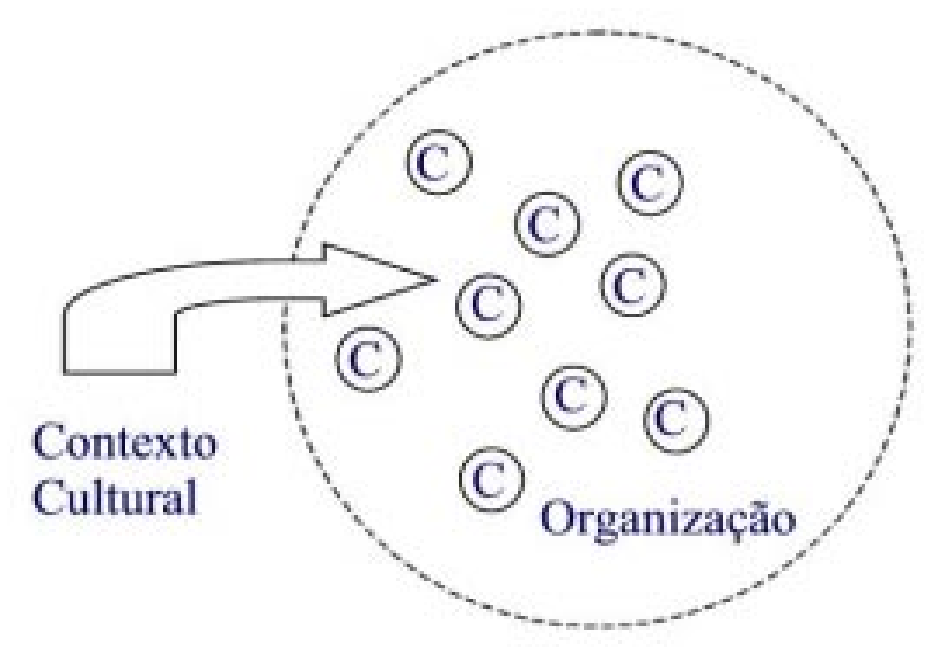

Figura 2: Modelo teórico dos estudos transnacionais segundo Smircich

Geertz Hofstede foi um dos autores que se notabilizou com o estudo de culturas nacionais a partir da IBM. Ele teve acesso a 116.000 questionários aplicados entre 1967 e 1973, em 72 subsidiárias diferentes, construídos a partir de entrevistas em profundidade com empregados de filiais de dez países diferentes. Em seu trabalho, foram identificadas quatro dimensões independentes, que ele denominou de "distância do poder", "evitar incertezas", “individualismo versus coletivismo" e "masculinidade versus feminilidade". Em estudos posteriores, sua equipe identificou um quinto fator independente que foi chamado de "dinamismo confuciano" e que opõe a orientação em curto prazo à orientação em longo prazo e foi usado para a construção de uma explicação parcial do sucesso das economias no oriente asiático, nas últimas décadas.

Esta linha de estudos apresenta alguns riscos, tanto teóricos quanto práticos. Um dos autores mais conhecidos por seus trabalhos acadêmicos e de consultoria na área de cultura organizacional, Edgar Schein, mostra os riscos da supersimplificação. 
Se eu quiser trabalhar na Alemanha, ajuda pouco saber que os alemães são compulsivos; se eu quiser trabalhar na Itália, não é tão útil saber que os italianos expressam suas emoções com liberdade e, se um alemão quiser trabalhar nos Estados Unidos, será de pouca valia saber que os americanos são individualistas. Esses insights podem ser proveitosos, mas não bastam. As culturas são padrões de elementos que interagem; se não tivermos como decifrar os padrões, não poderemos entender as culturas. (SCHEIN, 2001, p. 9)

O próprio Hofstede et al. (1990) admitiu que, após esses estudos, “a pesquisa transnacional na IBM nada revelou sobre a cultura corporativa da IBM", o que o levou a outros modelos de entendimento da cultura nas organizações.

Empregando a lógica derivada da análise fatorial, ele identificou seis pares de valores independentes para a análise de culturas organizacionais: orientação por processos versus orientação por resultados; orientação para a tarefa versus orientação para o empregado; profissional versus paroquial; sistemas abertos versus sistemas fechados; controles estritos versus controles "frouxos" e pragmáticos versus normativos.

O autor holandês sustenta este modelo de análise com base na independência dos fatores. Este argumento é útil para a construção de instrumentos e análise estatística, mas é insuficiente para responder, de forma substantiva, à necessária caracterização de uma cultura organizacional, que não se reduz a esses seis pontos descritivos, sem o sacrifício da compreensão.

Outros autores desenvolveram melhor o emprego de abordagens qualitativas e compreensivas no estudo da cultura, como bem o descreve Smircich (1983), e mesmo Hofstede discutiu com propriedade a questão da centralidade dos valores partilhados na análise cultural. 
3.3 Os estudos de cultura organizacional ou corporativa

O conceito de cultura organizacional abandonou o contexto sociocultural como origem dos fenômenos em estudo e voltou-se para o "interior" das organizações e das corporações (entenda-se por corporação como um conjunto de empresas sob mesma direção).

Smircich identificou diferentes focos e visões de organização nos estudos de cultura que analisou. Além dos estudos "transculturais", termo com que designou os estudos que comparam colaboradores de países ou regiões diferentes, esta autora relacionou os conceitos sintetizados no quadro 1.

Qual das linhas de trabalho deste quadro constitui a abordagem correta da visão de cultura? Possivelmente todas. Essas visões não são mutuamente exclusivas, mas também não podem ser apenas justapostas. Cada uma dela privilegia formas de pesquisa e análise de informações diferentes para o entendimento da abordagem de cultura da autora. Isso a levou a comparar o conceito de cultura com a imagem de um “código de muitas cores", ou de um arco-íris. 
Quadro 1:Diferentes padrões de estudos culturais em Administração

\begin{tabular}{|c|c|c|}
\hline Conceito de Cultura & Linha de Trabalhos & Visão de Organização \\
\hline $\begin{array}{l}\text { A cultura funciona como um } \\
\text { mecanismo regulatório- } \\
\text { adaptativo. Ela permite a } \\
\text { articulação dos indivíduos na } \\
\text { organização. }\end{array}$ & Cultura Corporativa & $\begin{array}{l}\text { As organizações são organismos } \\
\text { adaptativos que existem através } \\
\text { de processos de trocas com o } \\
\text { ambiente. }\end{array}$ \\
\hline $\begin{array}{l}\text { A cultura é um sistema de } \\
\text { cognições partilhadas. A mente } \\
\text { humana gera a cultura por meio } \\
\text { de um número limitado de regras. }\end{array}$ & Cognição Organizacional & $\begin{array}{l}\text { As organizações são sistemas de } \\
\text { conhecimento. A noção de } \\
\text { organização repousa sobre a rede } \\
\text { de significados subjetivos que os } \\
\text { membros partilham em vários } \\
\text { graus e que parecem funcionar de } \\
\text { uma maneira regular. }\end{array}$ \\
\hline $\begin{array}{l}\text { A cultura é um sistema de } \\
\text { símbolos e significados } \\
\text { partilhados. A ação simbólica } \\
\text { necessita ser interpretada, lida ou } \\
\text { decifrada, a fim de ser entendida. }\end{array}$ & Simbolismo Organizacional & $\begin{array}{l}\text { As organizações são padrões de } \\
\text { discurso simbólico. A } \\
\text { "organização é mantida através } \\
\text { de modos simbólicos como a } \\
\text { linguagem que facilita os } \\
\text { significados e as realidades } \\
\text { partilhados. }\end{array}$ \\
\hline $\begin{array}{l}\text { A cultura é uma projeção da } \\
\text { infraestrutura universal e } \\
\text { inconsciente da mente. }\end{array}$ & $\begin{array}{c}\text { Processos Inconscientes e } \\
\text { Organização }\end{array}$ & $\begin{array}{l}\text { Formas e práticas organizacionais } \\
\text { são as manifestações de processos } \\
\text { inconscientes. }\end{array}$ \\
\hline
\end{tabular}

Fonte: SMIRCICH, 1983.

Hofstede et al. (1990) crê que a maioria dos autores que estudam cultura organizacional concorda que ela é holística, é determinada historicamente, é relacionada a conceitos antropológicos, é socialmente construída, é maleável, mas não é facilmente modificável. Em um estudo posterior ao da IBM, ele comparou a cultura de 20 empresas que operavam na Dinamarca e na Holanda, que possuíam características culturais semelhantes (que ele denominou como sendo o aglomerado nórdico-holandês). Nesta pesquisa ele classificou as manifestações da cultura segundo o modelo abaixo: 


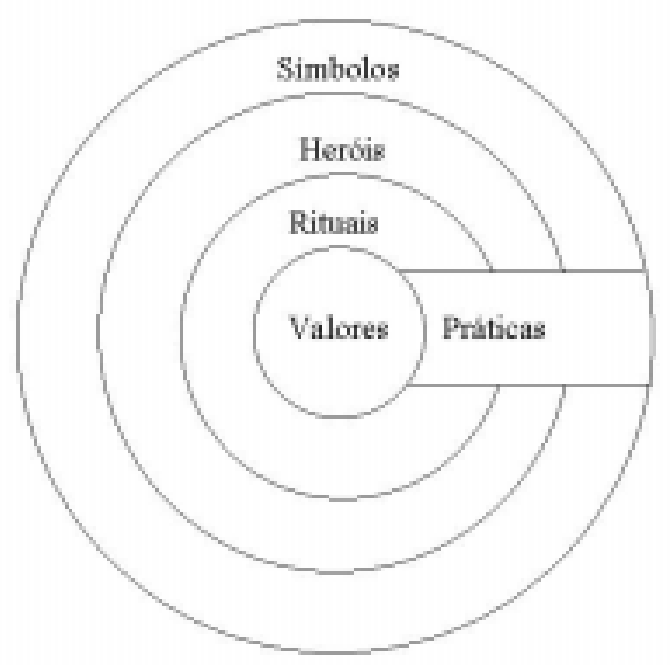

\section{Figura 3: Manifestações da cultura}

Fonte: Hofstede et al., 1990, p. 291.

Alguns autores trabalharam na consolidação dessas diferentes tendências. Edgar Schein desenvolveu uma proposta de trabalho variada, que inclui diferentes dimensões. Para ele, "cultura organizacional é o conjunto de pressupostos básicos que um grupo inventou, descobriu ou desenvolveu, ao aprender como lidar com os problemas de adaptação externa e integração interna e que funcionou bem o suficiente para ser considerado válido e ensinado a novos membros, como a forma correta de perceber, pensar e sentir em relação a esses problemas".

Schein procurou elaborar um conceito de cultura, concebendo-a como um modelo dinâmico em que é aprendida, transmitida e mudada. Ele aceita que o conceito é complexo o suficiente para ser empregado na compreensão de fenômenos de grupos pequenos como uma equipe de trabalho ou grandes como uma nação ou uma sociedade.

Há três diferentes níveis através dos quais a cultura de uma organização pode ser apreendida, como se pode ver na figura 4, segundo Schein. 
- Artefatos Visíveis, como os produtos visíveis: Layout da organização, comportamento e vestuário das pessoas, rituais, mitos organizacionais, assim como crenças expressas em documentos - fáceis de serem percebidos, mas difíceis de serem interpretados;

- Valores Compartilhados: Aqui o autor aponta o problema da diferença existente entre os valores aparentes e os valores em uso. Para identificar esses valores é difícil fazê-lo através de uma observação direta, é preciso entrevistar os membros chaves da organização, ou realizar a análise de conteúdo de documentos formais da mesma. Entretanto, ao identificar esses valores, eles expressam o que as pessoas reportam ser a razão do seu comportamento, o que na maioria das vezes são idealizações ou racionalizações. As razões subjacentes ao seu comportamento permanecem, entretanto, escondidas ou inconscientes;

- Pressupostos Básicos: Normalmente inconscientes, mas que na realidade determinam como os membros do grupo percebem, pensam e sentem. À medida que certos valores compartilhados pelo grupo conduzem a determinados comportamentos, e esses comportamentos se mostram adequados para solucionar problemas, o valor é gradualmente transformado em um pressuposto inconsciente de como as coisas realmente são.

O modelo da figura 4 não é apenas uma forma de se apresentarem informações sobre a cultura organizacional. Os níveis nela apresentados interagem entre si, ou seja, os níveis "inferiores" são fundamentais para a compreensão dos artefatos visíveis. Schein afirmou que os empregados de uma empresa formal e burocratizada podem compartilhar valores e pressupostos básicos semelhantes aos de uma empresa do tipo "casual" e horizontalizada. Por essa razão, os estudos de cultura organizacional não 
podem restringir-se à observação dos artefatos visíveis. É necessário dialogar com os membros de uma organização para o entendimento do seu significado. Mesmo assim, as explicações dos membros da organização ainda não são suficientes, porque existem pressupostos subjacentes considerados tão óbvios que nunca são enunciados. Estes pressupostos influenciam todo o processo de interação dos membros da empresa sem que eles se percebam disto a maior parte do tempo.

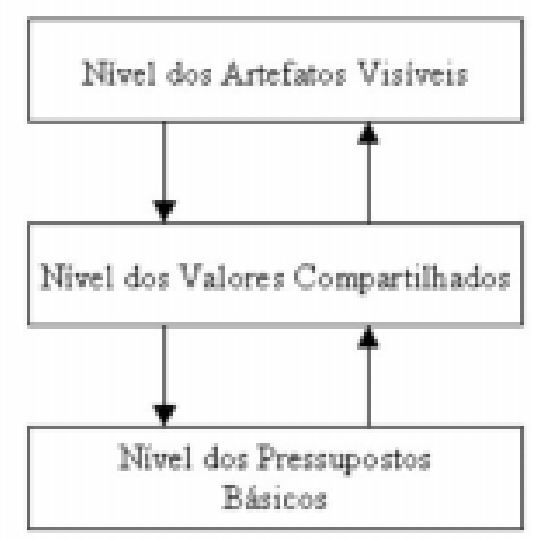

Figura 4: Níveis de análise da cultura organizacional de Schein

Fonte: SCHEIN (1992, p. 17)

Schein atribui maior importância ao papel dos fundadores da organização no processo de moldar seus padrões culturais: os primeiros líderes, ao desenvolverem formas próprias de equacionar os problemas da organização, imprimiriam não só sua visão de mundo aos demais como também a visão do papel que a organização deve desempenhar no mundo.

Esses pressupostos básicos não estão organizados aleatoriamente; padronizam-se em paradigmas culturais, com alguma ordem e consistência para orientar a ação do ser 
humano. No entanto, é possível coexistirem pressupostos incompatíveis e inconsistentes em uma organização.

\subsection{Pressupostos básicos: de Bion a Schein}

A compreensão da cultura de uma organização implica a discussão de seus pressupostos básicos. "Pressupostos sobre o quê?" (SCHEIN, 1992, p. 49). Ele responde a esta pergunta com um tripé conceitual: o ambiente externo, o ambiente interno e temas estruturantes como: a natureza da verdade, do tempo, do espaço, da natureza humana, das atividades humanas e dos relacionamentos humanos.

Os dois primeiros itens consideram a sobrevivência e a adaptação da organização a ambientes externos e o gerenciamento da integração interna, vistos como duas faces de uma moeda.

A maioria das organizações trabalharia com os seguintes passos:

a) visão compartilhada da missão e da estratégia;

b) consenso quanto aos objetivos derivados da função central;

c) consenso quanto aos meios a serem usados para chegar aos objetivos, tais como a estrutura organizacional, divisão do trabalho, sistema de recompensas e sistema de autoridade;

d) consenso quanto a sistemas de medidas ou informações sobre como os grupos estariam cumprindo suas metas;

e) consenso quanto ao remédio apropriado ou estratégias de reparo a serem usadas se os objetivos não estiverem sendo atingidos.

Com relação à integração interna Schein destaca:

a) criação de uma linguagem interna e categorias conceituais próprias da organização; 
b) critérios de inclusão e exclusão de membros, bem como das fronteiras entre grupos componentes da organização;

c) critérios para obter, manter e perder o poder;

d) normas de intimidade, amizade e amor;

e) alocação de recompensas e punições;

f) processos grupais para a explicação do inexplicável, criação de significação para o estranho.

Schein, utilizando como referência os trabalhos de Florence Kluckhohn (1965), propõe um conjunto de categorias para o estudo da cultura (SCHEIN, 1992, p. 95), a saber:

a) natureza da verdade e da realidade;

b) natureza do tempo;

c) natureza do espaço;

d) natureza da natureza humana;

e) natureza da atividade humana;

f) natureza dos relacionamentos humanos.

Fleury e colaboradores (1997a, 1997b) fizeram uma análise comparativa entre a teoria de Bion sobre pressupostos básicos e a de Schein. Eles reconhecem que o conceito de pressuposto básico de Schein, apesar de conter semelhanças indiscutíveis com o de Bion, não se identifica totalmente com ele. Da mesma forma, o conceito de cultura de grupo de Bion mantém certa semelhança com o de cultura organizacional de Schein, mas de modo algum podem ser considerados idênticos. 
Três conceitos são centrais no entendimento da dinâmica dos grupos na teoria de Bion: o de grupo de trabalho, o de pressupostos básicos e o de mentalidade de grupo que permite o surgimento de uma cultura de grupos.

Por grupo de trabalho entende-se a reunião de pessoas para a realização de uma tarefa específica, no qual se consegue manter um nível refinado de comportamento identificado pela cooperação. Cada um dos membros contribui com o grupo de acordo com sua capacidade individual, e desse modo, consegue-se um bom espírito de grupo. Por espírito de grupo, Bion (1975, p. 18) entende:

a) a existência de um propósito comum;

b) o reconhecimento comum dos limites de cada membro, sua posição e sua função em relação às unidades e grupos maiores;

c) a distinção entre os subgrupos internos;

d) a valorização dos membros individuais por suas contribuições ao grupo;

e) a liberdade de locomoção dos membros individuais dentro do grupo;

f) a capacidade de o grupo enfrentar descontentamentos dentro de si e de ter meios de lidar com eles.

O grupo de trabalho, entretanto, não funciona exclusivamente com base nos objetivos explícitos e na colaboração intencional e consciente das pessoas. Para o psiquiatra inglês, ele é mobilizado igualmente por fenômenos inconscientes coletivos que emergem nas pessoas pelo fato de estarem em grupo, que ele denominou de pressupostos básicos. Nesse trabalho, Bion se refere a esses pressupostos apenas como "padrões de comportamento", que foram constatados em sua experiência terapêutica com grupos. Na sua obra ele descreve três padrões: o da demanda de um líder provedor, o da esperança no surgimento de um grupo melhorado e o da existência de algo contra o 
qual o grupo luta ou do qual deve fugir. Os membros do grupo não se dariam conta de que estariam agindo em função dos pressupostos básicos. Esse tema foi desenvolvido um outro trabalho (SAMPAIO, 2002).

Apesar das categorias traçadas e do roteiro metodológico, em um trabalho futuro Schein (1993, p. 705) apresentaria os pressupostos básicos de uma forma menos categórica e mais conectada às práticas vigentes na organização, relacionando temas do cotidiano, como: qual deve ser o tipo e a qualidade do produto; qual a imagem básica sobre o negócio; como levar o produto ao mercado; como são os consumidores; se o funcionamento é voltado ao consumidor ou ao produto; se se deve endividar a organização e se ela deve tornar-se pública ou continuar privada.

Eu descobri que as empresas constroem fortes pressupostos básicos sobre estes assuntos e que estes pressupostos dominam o processo de tomada de decisão e a estratégia. Como eu irei descobrir estes pressupostos se adentrála com um questionário preparado ou um roteiro de entrevistas baseado em uma tipologia de organizações desenvolvido para explorar as relações entre superior e subordinado? (SCHEIN, 1993, p. 705)

Schein (2001) analisou o processo de aquisições, fusões e constituição de joint ventures, no qual verificou que "as questões culturais se tornam mais barulhentas e visíveis". Esses casos assemelham-se aos experimentos de figura e fundo que os psicólogos estudaram no início do século XX, nos quais um observador vê modificar-se, diante de seus olhos, uma imagem, que tem traços pertencentes ao fundo, em uma perspectiva, e passam a fazer parte de uma nova figura, após uma simples mudança de ponto de vista.

Essa linha de estudos, a despeito de suas origens psicológicas e antropológicas, assume os sistemas culturais apenas em sua capacidade de comunicação e de expressão de uma visão consensual sobre a própria organização. A dimensão do poder, intrínseca aos sistemas simbólicos, e o seu papel de legitimação da ordem 
vigente e de ocultação das contradições, das relações de dominação, estão ausentes nesses estudos.

O debate com as várias linhas teóricas que trabalham com a questão da cultura organizacional apontou a necessidade de elaboração de uma proposta conceitual que, partindo da concepção de Schein, incorporasse a dimensão política inerente à cultura.

$\mathrm{Na}$ proposta elaborada por Fleury (1989), a cultura organizacional é concebida como um conjunto de valores e pressupostos básicos, expresso em elementos simbólicos que, em sua capacidade de ordenar, atribuir significações, construir a identidade organizacional, tanto agem como elemento de comunicação e consenso, como ocultam e instrumentalizam as relações de dominação.

Analisar, pesquisar e até mesmo procurar gerenciar a cultura das organizações, incorporando a dimensão política das relações de poder, tem sido o desafio de muitos pesquisadores e profissionais.

3.5 A metodologia de análise da cultura organizacional proposta por Fleury.

Os elementos simbólicos visíveis: o ambiente construído da organização e o comportamento das pessoas constituem a camada mais superficial; em uma camada mais profunda as estórias, os mitos, os heróis, os fundadores; e, por fim, no centro, os valores da organização. Um recorte formado pelas políticas e práticas de gestão atravessa as várias camadas e possibilita chegar aos valores daquela organização. 


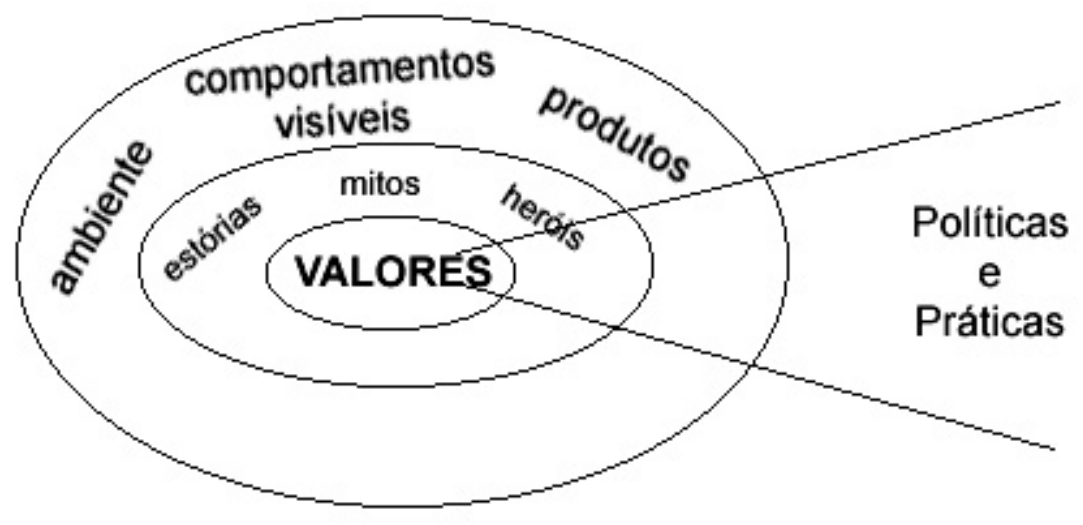

Figura 5: Níveis de apreensão da cultura organizacional de Fleury

Fonte: Fleury, M. T., Sampaio, J. (2002)

Fleury (1989) desenvolveu uma proposta de análise cultural que não perde de vista as relações de trabalho e de poder. Ela aponta cinco dimensões que precisariam ser percorridas pelo pesquisador de organizações e que orientam a leitura do simbólico e dos valores.

A primeira dimensão envolve o histórico da organização, focalizando o "momento de criação" e a figura do fundador. Outro ponto que o pesquisador não deve perder de vista são os "incidentes críticos pelos quais passou a organização", como as crises, decisões importantes, sucessos, fracassos.

A segunda dimensão é "o processo de socialização dos novos membros”, em que, privilegiadamente, transmitem-se os valores e comportamentos esperados para os novos membros.

A terceira dimensão constitui-se das políticas de recursos humanos, e envolve captação, seleção, treinamento, qualificação, avaliação, remuneração e carreiras dos membros da organização. 
A quarta dimensão é o processo de comunicação, que compreenderia o mapeamento do sistema de comunicações, identificação dos meios formais e informais e as novas políticas e práticas de comunicação empresarial.

A quinta dimensão envolve a organização do processo de trabalho, abordando, ao mesmo tempo, a sua "vertente tecnológica" e a sua "componente social". Com essas categorias, Fleury desenvolveu, de forma sistemática, uma abordagem concreta e voltada para a análise cultural de empresas.

3.7 Articulando o estudo das estruturas organizacionais ao estudo de cultura.

A estrutura organizacional das OTS é um aspecto a ser destacado para o entendimento de sua cultura. Há organizações de estrutura pré-burocrática (WAGNER III, HOLLENBECK, 2000) e organizações burocráticas com diversos níveis hierárquicos, em decorrência de fatores como o número de pessoas, atividades realizadas, recursos disponíveis, parcerias, etc.

O trabalho em equipe, embora não venha sendo teorizado a partir da análise de atividades de OTS, neste contexto já é uma realidade, muito semelhante à dos chamados grupos semi-autônomos (MARX, 1998). Tais organizações, entretanto, não vêm se estruturando aos moldes do que Wagner III e Hollenback denominam ser estruturas pós-burocráticas.

A análise da estrutura organizacional se mostra potencialmente frutuosa para o entendimento da discrepância entre as relações hierárquicas prescritas e as relações reais. No caso do Terceiro Setor, onde as técnicas administrativas não se encontram difundidas, há uma grande possibilidade de se encontrarem estruturas formalistas, que não reflitam as relações hierárquicas. 
Outra possibilidade desse tipo de análise é a comparação entre o projeto original do fundador e as mudanças subseqüentes, quando existe algum tipo de memória da trajetória organizacional.

O estudo da cultura organizacional proposto por Fleury para a análise de empresas, considerando as suas mudanças estruturais, é uma base segura que permite o desenvolvimento de um modelo de pesquisa mais ajustado à realidade das organizações de Terceiro Setor. Do modelo teórico de Geertz (1989), retirar-se-ão os conceitos centrais para o desenvolvimento de categorias que permitam uma análise da cultura do movimento de fundo da organização, o que parece ser necessário para a compreensão de conflitos entre crenças, atitudes, valores individuais e as crenças, atitudes e valores coerentes com o projeto organizacional, assim como os pressupostos básicos que vieram sendo desenvolvidos desde a fundação da organização. O desenvolvimento desta proposta encontra-se desenvolvido no capítulo 5. 


\section{MOTIVAÇÃO: A TRAJETÓRIA DE UM CONCEITO IMPRECISO}

- Quanto é que ele te pagou? Eu posso dar o dobro, te dou tudo o que tiver! - Não tem jeito, não tem jeito, Seu Turíbio... Abaixo de Deus foi ele quem salvou a vida do meu menino... E eu prometi, quando ele já estava de vela na mão... É minha tristeza! Mas jeito não tem... Tem remédio nenhum... João Guimarães Rosa.

A tentativa de entendimento do conceito de motivação pode ser adequadamente ilustrada pelo conhecido conto indiano dos cegos e do elefante. Dada a complexidade do homem e dos grupos sociais aos quais se vincula, historicamente os autores que trataram do tema procuraram um "apoio de Arquimedes" para reduzir o conceito e, a partir dele, "mover o homem".

As metodologias reducionistas, em que pese a sua pretensão científica, parecem ter sido antecipadas por paradigmas ontológicos, que suas descobertas não foram capazes de falsificar ou de discutir, e que acabaram sendo aceitos como idéias apriorísticas.

A maioria dos autores $^{12}$ que se dedicou à realização da revisão dos construtos concorrentes sobre motivação percebeu essa diversidade. As tentativas de classificação das teorias propostas são igualmente diversas. O que se tem é uma multiplicidade de construtos, essencialmente diferentes uns dos outros, designados pela mesma palavra, que se tornou uma espécie de termo "guarda-chuva". De forma geral, os elementos conceituais de motivação empregados por um dos autores são criticados por outro. As teorias subjacentes são igualmente complexas, e a tentativa de explicação delas, em alguns parágrafos, tem gerado graves problemas de entendimento na literatura.

\footnotetext{
${ }^{12}$ McClelland et al, 1953; Muchielli, 1981; Haslam, 2001, Nuttin, 1980, Madsen, 1967.
} 
Madsen (1967) fez um apanhado amplo e bem comentado, mas os autores revistos e apresentados contam-se às dezenas. É uma boa leitura introdutória para o pensamento desses autores, que desenvolveu, porém, um quadro de referência muito extenso. Bowditch e Buono (1992) distinguem teorias de conteúdo estático, teorias de processo e teorias baseadas no ambiente, o que é uma contradição, posto que nenhuma das teorias denominadas como "de conteúdo estático" deixa de propor um processo motivacional, e as chamadas teorias de processo não abandonam os conteúdos estáticos, nem desconsideram a importância do ambiente.

Na tentativa de entender a abrangência dos estudos sobre motivação, após rever diversos quadros de síntese, optou-se pelo trabalho de Muchielli (1981), que classifica as principais teorias existentes em quatro grandes categorias: concepções inatistas, concepções situacionistas, concepções empiristas e concepções interacionistas.

a) Concepções inatistas: são as que entendem que existem no indivíduo características fundamentais, constitutivas da "natureza humana", que determinam o comportamento. Muchielli (1981) entende que diversos autores desenvolveram suas proposições teóricas dentro desta corrente, como Platão e Descartes, na Filosofia, e Freud (ao propor a teoria pulsional), Pierón, Murray e Maslow, na Psicologia.

b) Concepções situacionistas: são as que entendem que "a origem dos comportamentos é exterior ao indivíduo", que seria determinado a agir pela influência dos elementos do ambiente que atuam sobre ele. Dentre os autores classificados nesta categoria temos Marx (que ele faz com reservas), Durkheim, Crozier e Boudon. Quase todos estes são autores que se aproximam do que Muchielli denomina de sociologismo. 
c) Concepções empiristas: são as que se baseiam na concepção lockiana de que o homem nasce como uma "tabula rasa", em que as experiências da vida vão inscrevendo seus conteúdos, tornando-o um resultado condicionado pelo seu passado. Estranhamente, autores da Psicologia como Watson, Skinner e os comportamentalistas radicais, que desenvolveram seus sistemas rigorosamente dentro desta perspectiva, não foram lembrados por Muchielli. Este preferiu situar, contraditoriamente, a tradição psicanalítica, devido ao fato de a maioria dos seus autores ter privilegiado "uma situação afetiva fundamental, determinante das condutas posteriores do indivíduo" ${ }^{\text {13 }}$. Ele faz referências a Freud, a Adler, a Horney e a Fromm.

d) Concepções interacionistas: são as dos autores que entendem que a motivação não tem origem nem exclusivamente interna, nem exclusivamente externa. Muchielli cita Kurt Lewin como um dos pioneiros deste quadro e destaca Joseph Nuttin como um dos autores que melhor desenvolveu esta perspectiva.

Aceita a pluralidade de abordagens, torna-se imperioso o entendimento e a explicitação das escolhas teóricas para a construção de um modelo que orientará a coleta e análise da motivação de voluntários. Optou-se por realizar uma leitura aprofundada da obra de três autores de diferentes orientações, que se dedicaram ao estudo da motivação: Maslow, McClelland e Nuttin. Eles foram escolhidos por diversas razões:

a) são representantes de diferentes abordagens, o que permite uma análise comparativa entre elas;

b) são destacados pelos especialistas da pesquisa básica de motivação;

\footnotetext{
${ }^{13}$ MUCHIELLI, 1980, p. 15.
} 
c) justificaram os fundamentos do seu arcabouço teórico, não se limitando a apenas aplicar um paradigma vigente no mundo do trabalho;

d) desenvolveram modelos explicativos e compreensivos dos processos motivacionais, não se limitando a apenas registrar associações de variáveis consideradas importantes no entendimento da motivação;

e) permitem o desenvolvimento de uma proposta de pesquisa mais ampla e compreensiva da motivação de voluntários.

\subsection{As contribuições de Abraham Maslow}

Um dos autores mais citados e criticados por estudiosos de comportamento organizacional, no capítulo do estudo da motivação, é o americano Abraham Maslow. Entretanto, a leitura um pouco mais cuidadosa da sua obra mostra o quanto esses estudiosos reduziram e descaracterizaram o pensamento deste psicólogo norteamericano.

Maslow foi um psicólogo formado na Universidade de Wisconsin e tinha, por diretriz de trabalho, uma tentativa de síntese das ênfases dinâmica, holística e cultural. Essa pretensão se deve às muitas e ilustres influências que recebeu durante sua trajetória: estudou Gestalt em Nova York, Psicanálise com Kardiner, Erich Fromm e Karen Horney e Antropologia com Ruth Benedict, Margareth Mead e Ralph Linton. Foi assistente de Thorndike e, como todo psicólogo de sua época, teve sua formação marcada pela escola Behaviorista, da qual se tornou crítico. Sofreu, também, influências dos pensamentos de Gordon Allport, Murray e Carl Rogers. Como se pode ver, trata-se de um autor que passou pelas chamadas grandes escolas da Psicologia (Escola 
comportamental, Psicanálise e Humanismo) e pelas contribuições norte-americanas à Antropologia.

Diferentemente do que se pensa, seus estudos sobre motivação humana tinham em vista o desenvolvimento de uma teoria que pudesse servir de base para a compreensão do homem inserido na sociedade, e não se aplica facilmente quando reduzida ao aspecto da vida laboral.

Muchielli (1981) classificou sua teoria da motivação como inatista.

4.1.1 A visão de ciência e de homem, segundo Maslow

O que se depreende de seus trabalhos é um posicionamento crítico à análise do homem quando se acha reduzida a apenas uma de suas dimensões, como o organismo, o inconsciente, o comportamento ou os papéis sociais. Ele denomina este tipo de análise com o termo "atomismo metodológico" (MASLOW, 1954. p.23) e a ele opõe seu método de pesquisa e análise que denomina como "holístico dinâmico".

Nós sabemos que o dado fundamental da Psicologia não é uma contração muscular, nem um reflexo, nem uma sensação elementar, nem um neurônio, nem mesmo uma partícula observável do comportamento visível. É uma unidade muito maior, e mais e mais psicólogos pensam que é no mínimo tão amplo como uma unidade de ajustamento ou ato de adaptação, que necessariamente envolve um organismo, uma situação e um objetivo ou propósito. (MASLOW, 1954. p. 22)

Este ponto de vista holístico-dinâmico pode ser entendido a partir do contraponto que este autor fez entre as características de seu método e as dos métodos que critica. 
Quadro 2: Comparação feita por Maslow entre métodos de pesquisa

\begin{tabular}{c|c}
\hline Método Dinâmico-Holístico & Métodos Empíricos \\
\hline Holístico & Atomístico \\
Funcional & Taxonômico \\
Dinâmico & Estático \\
Dinâmico & Causal \\
Proposital & Mecânico-simples \\
\hline
\end{tabular}

Fonte: MASLOW, 1954. p. 27

Esta posição metodológica fica mais clara quando se lê a descrição que este

autor fez dos procedimentos de uma pesquisa sobre auto-estima, relacionada ao entendimento da personalidade:

Portanto, antes que qualquer questão fosse feita especificamente a um sujeito, foram feitas explorações sobre as relações do sujeito com a sua família, o tipo de subcultura em que vive, seu estilo geral de ajustamento aos principais problemas de sua vida, o estilo geral de seus ideais, suas frustrações e seus conflitos. Este procedimento continuava até que o escritor sentia que ele compreendia o sujeito tão bem quanto possível com as técnicas simples que estavam sendo utilizadas. (MASLOW, 1954. p. 25)

Neste trabalho, Maslow propõe que se abandone a terminologia da causalidade, que ele considera problemática devido ao seu mecanicismo, e adota o termo síndrome, para descrever "um complexo estruturado, organizado, de especificidades aparentemente diversas (comportamentos, pensamentos, impulsos para a ação, percepções, etc.) ... que possuem uma unidade comum e podem ser nomeados de forma variada...”. (MASLOW, 1954. p. 32)

Aqui se vê a tentativa de empreender uma abordagem compreensiva para o entendimento do homem. Os estudos sobre Psicanálise e Antropologia Cultural deixaram marcas no trabalho deste autor, que percebeu, com clareza, a polissemia que envolve determinado comportamento e a fragilidade dos modelos biologicistas para entender o homem em sua complexidade. Ele ilustra esta posição afirmando que a pessoa que apresenta o comportamento de freqüentar regularmente um grupo religioso pode fazê-lo por razões variadas, como "para evitar o isolamento social", "para agradar à mãe”, para empregar a religião como instrumento de dominação sobre outras pessoas, 
para sentir-se "membro de um grupo superior" ou por entender que é bom "para as massas ignorantes" e que se deve desempenhar o seu papel. Com esse tipo de posição teórico-metodológica, ele critica a eleição do comportamento humano como unidade de análise, exige do fatorialismo uma interlocução com os sujeitos de pesquisa e articula o entendimento da pessoa ao seu entorno social, para fugir do individualismo e, ao mesmo tempo, dos reducionismos sociológicos, que se furtam à compreensão do indivíduo, fazendo análises generalizantes a partir de rótulos de pertença a grupos sociais.

Maslow, portanto, apóia-se em uma visão de homem racional, mas às voltas com seus impulsos e desejos; dotado de corporalidade, não circunscrito, todavia, a ela; possuidor de uma vida interior, que não pode ser reduzida à mera manifestação da cultura ou da sociedade e que não se acha descolada destas; em interação interpessoal, mas também com elementos coletivos, é um "todo integrado e organizado" e capaz de escolhas e de criação de significado para a realidade. Esse autor, entretanto, é bastante influenciado pela visão organísmica de homem, na medida em que tenta mostrar qual é o impacto da gratificação das necessidades nas idéias, atitudes, interesses, valores e crenças que defende, dando um certo destaque a este construto.

É, portanto, imprecisa a leitura mecanicista que a grande maioria dos autores de Comportamento Organizacional fazem de seu trabalho, reduzindo-o, incorretamente, à hierarquia de necessidades. Sobre esta trataremos mais profundamente no decorrer deste trabalho.

\subsubsection{O conceito de motivação}

O mais citado capítulo de Maslow sobre motivação foi denominado "Uma Teoria da Motivação Humana", e é nele que se lê sobre a hierarquia das necessidades. 
Entretanto, ele redigiu um "Prefácio à Teoria da Motivação", no qual enumera 16 proposições "que precisam ser incorporadas a qualquer teoria relevante de motivação". De uma certa forma, ele circunscreve e caracteriza o conceito de motivação neste capítulo.

Não se pretende reproduzir os princípios na íntegra, mas apenas mostrar ao leitor que a motivação em Maslow não é mecanicista nem atomística, como pretendem alguns dos seus leitores mais conhecidos no campo do comportamento organizacional.

Maslow parte do pressuposto de que o indivíduo é um todo integrado e organizado (MASLOW, 1954, p. 63), e desenvolve essa idéia, ao mostrar que não se pode falar da motivação de um órgão (a boca, o estômago ou a genitália), mas apenas da motivação da pessoa como um todo.

Outro de seus pressupostos é a não-diferenciação entre os motivos biológicos e os motivos culturais, que ele reputa ao fato de os cientistas do comportamento considerarem os últimos como secundários, dando a entender que se trata de um resquício da visão materialista do homem e da visão empirista de ciência.

O típico impulso, ou necessidade ou desejo não é e provavelmente nunca estará associado a uma base somática específica, isolada. (...) Considerando todas as evidências que temos em mãos, é muito pouco provável que compreendamos totalmente o desejo de amar, não importa o quanto saibamos sobre o impulso da fome. (MASLOW, 1954, p. 63)

Apesar de esta idéia fazer parte de seus pressupostos, Maslow parece não a ter considerado, ao continuar a formulação da sua teoria sobre motivação.

Outro de seus pressupostos repousa na distinção entre impulsos e necessidades. Ele percebe que o ser humano é capaz de empregar determinados meios para atingir alguns fins, como é ilustrado com a idéia de obter-se dinheiro para comprar um automóvel, ao mesmo tempo em que se compra um automóvel, tendo em vista o 
prestígio que este veículo gera junto às pessoas que fazem parte do meio social do comprador.

Em outras palavras, portanto, o estudo da motivação deve ser, em parte, o estudo dos objetivos últimos ou desejos ou necessidades humanas. (MASLOW, 1954, p. 66)

Portanto, entende-se que Maslow distingue impulsos de necessidades, situando nestas os desejos. Os impulsos teriam base orgânica, enquanto que as necessidades seriam mobilizadas a partir de uma finalidade social que se almeja.

Essa distinção não é mantida no desenvolver do seu trabalho, porque Maslow cria o conceito de "necessidades fisiológicas", que, a rigor, continuam sendo impulsos. Esse autor parece permitir-se essa pequena confusão porque o seu conceito de motivação se baseia em uma teoria de privação/gratificação.

... a gratificação se torna um conceito tão importante como a privação na teoria da motivação, porque ela livra o organismo da dominação de uma necessidade mais fisiológica, permitindo então a emergência de outros objetivos mais sociais. (MASLOW, 1954, p. 84)

Entende-se bem o conceito de motivação quando Maslow trata, em sua obra, do comportamento não motivado.

A gratificação de necessidades permite a emergência de comportamento relativamente não-motivado... O organismo permite-se relaxar, ser passivo, aproveitar o sol, ornamentar, decorar e polir os potes e vasilhas (mais que usá-los), jogar e divertir-se, observar coisas sem importância, ser informal e sem aspirações. (MASLOW, 1954, p. 294)

Desta forma, a arte (quando puramente expressiva) seria um exemplo de comportamento não motivado. Vê-se, portanto, que a motivação em Maslow está claramente associada à existência de um propósito, uma finalidade, um objetivo; e que este propósito incomoda (motiva) a pessoa até que seja atingido. Uma necessidade, portanto, é algo do mundo interno das pessoas cuja privação a mobiliza.

Outra distinção que Maslow faz é entre as noções de determinação e motivação. Existem determinantes não motivacionais, como a ação glandular, ou a ação 
de substâncias sobre a pele, desencadeadas pela exposição ao sol, mas esses mecanismos fisiológicos não mobilizam a pessoa a um objetivo, são meras reações biológicas. Portanto é incorreto afirmar que os motivos são determinantes, uma vez que estes se encontram mediados pela ação da consciência. Como necessidades, eles são apenas mobilizadores do indivíduo, que busca satisfazê-los.

Maslow aceita algumas idéias da psicanálise para a construção de sua teoria motivacional. Ele admite uma dinâmica motivacional em que o desejo é sempre permanente, embora seus objetivos e objetos estejam constantemente sendo mudados pela pessoa.

O homem é um animal desejante e raramente atinge um estado de completa satisfação exceto por um curto período de tempo. Assim que um desejo é satisfeito, outro explode e assume o seu lugar. (MASLOW, 1954, pág. 69)

A sobredeterminação de Freud também é empregada por Maslow ao descrever os estados motivacionais, como se lê na citação abaixo:

Deixe-nos enfatizar que é raro, não usual, que um ato ou desejo consciente tenha somente um motivo. (MASLOW, 1954, p. 68)

\subsubsection{Classificação dos motivos}

Uma vez delimitado o conceito de motivação, o autor se deparou com o problema de classificar tipos de motivos. Ele conhecia os problemas que a tentativa de se listarem os instintos humanos trouxera à psicologia do início do século XX e, por esta razão, classificou as necessidades, buscando a sua finalidade, como se pode ler na citação abaixo:

A ação, da forma como aparece introspectivamente na consciência, o comportamento motivado, e até os objetos-meta, explicitamente aparentes, ou efeitos procurados não são uma base sólida para uma classificação dinâmica da vida motivacional do ser humano. Se nos guiamos apenas pelo processo de exclusão lógica, ficamos finalmente com os objetivos fundamentais largamente inconscientes ou necessidades como a única base 
sólida para classificação na teoria da motivação. (MASLOW, 1954, p. 72)

Maslow afirma que sua classificação "é derivada mais diretamente da experiência clínica" (MASLOW, 1954, p. 80), mas apesar desta afirmação, o leitor atento percebe que se trata mais da formulação de um construto teórico em que seu autor busca articular diferentes contribuições da psicologia como a psicanálise freudiana e adleriana, o funcionalismo de William James e Dewey, o holismo de Wertheimer, o organicismo de Goldstein e os estudos fisiológicos de Cannon.

As necessidades, portanto, foram classificadas da seguinte forma:

a) necessidades fisiológicas que compreendem a noção de impulsos ${ }^{14}$, acrescida da noção de homeostase de Cannon e da idéia de apetites (que introduz a escolha de alimentos pela pessoa ao tema da fome);

b) necessidades de segurança que ele entende ser uma classificação grosseira. Por necessidade de segurança depreende-se a inexistência de ameaças percebidas no ambiente. Maslow cita os trabalhos experimentais realizados com crianças, para ilustrar seu conceito, e trabalhos clínicos com neuróticos obsessivo-compulsivos, que procuram organizar o mundo de forma a evitar suas ameaças inesperadas, e com lesionados cerebrais que evitam tudo o que lhes é estranho ou não familiar. Assim o conceito de segurança de Maslow compreende uma certa estabilidade, entendimento e controle dos padrões de mudança do ambiente em que a pessoa se encontra;

c) necessidades de pertencimento e amor que é entendida como o compartilhamento de afeto com pessoas em um círculo de amizade e intimidade. Embora a sexualidade possa fazer parte desse contexto de intimidade, o conceito

\footnotetext{
${ }^{14}$ Do inglês drives.
} 
de amor não se reduz ao de sexo. O comportamento sexual é multideterminado, e pode ser enfocado na ótica das necessidades fisiológicas.

d) necessidades de estima que compreendem a imagem que a pessoa tem de si (auto-estima ou auto-respeito) e o desejo de obter a estima dos outros. Ele divide estas necessidades em dois conjuntos. No primeiro, ele situa o desejo de "realização, de adequação, de maestria e de competência", que possibilita a confiança com relação ao mundo, independência e liberdade. No segundo, ele situa a busca de "reputação ou prestígio, "status", dominância, reconhecimento, atenção, importância ou apreciação". A base desse conjunto de necessidades é encontrada na teoria psicanalítica adleriana, e a influência psicopatológica da falta de gratificação dessas necessidades é exemplificada com os estudos de neuróticos de guerra de Kardiner;

e) necessidades de auto-realização ou auto-atualização que compreendem a idéia defendida por muitos autores (como Jung, Goldstein, p.e.) em que se entende que as pessoas têm um potencial interno que necessita tornar-se ato. Maslow dedica dois capítulos à auto-realização nos quais mostra dados colhidos a partir de análises biográficas de figuras históricas, estudo de pessoas contemporâneas de destaque e jovens que pareciam estar se desenvolvendo rumo à auto-atualização;

f) desejos de saber e de entender ${ }^{15}$ que Maslow considera menos conhecidos, porque não possuem implicações clínicas, que são a principal base do conjunto de categorias desenvolvido por ele. Entretanto, ele as considera como

\footnotetext{
${ }^{15}$ Emprega-se aqui o termo usado por Maslow em seu trabalho de 1954. Posteriormente ele empregaria a expressão "Necessidade de Conhecer" (need to know), como se pode ver nos títulos de alguns de seus artigos posteriores.
} 
necessidades e sujeitas à gratificação como as demais. Elas são postuladas por Maslow como "um desejo de entender, de sistematizar, de organizar, de analisar, de procurar por relações e significados, de construir um sistema de valores." (MASLOW, 1954, p. 97);

f) necessidades estéticas que ele entende como os impulsos à "beleza, simetria, e possivelmente à simplicidade, à inteireza e à ordem". Ele afirma que observou essas necessidades em crianças saudáveis, mas que se encontram indícios delas "em todas as culturas e em todas as idades".

Essas sete grandes categorias compreendem o que Maslow denomina de as necessidades básicas, ao contrário do que se encontra na grande maioria dos livros de comportamento organizacional que negligenciam as duas últimas. O próprio Maslow deixa este entendimento claro em passagens como a que se segue:

Nós devemos preservar-nos da fácil tendência a separar estes desejos ${ }^{16}$ das necessidades básicas que discutimos acima, isto é, de fazer uma dicotomia marcada entre necessidades cognitivas e conativas. O desejo de saber e de entender é conativo em si, isto é, possui a característica de conduzir a um objetivo e é uma necessidade da personalidade assim como as necessidades básicas que já discutimos. (MASLOW, 1954, p. 97)

4.1.4 A proposição de hierarquia da preponderância das necessidades

A hierarquia das necessidades surge como conceito à medida que o autor classifica suas categorias como superiores e inferiores, e faz a seguinte consideração sobre a sua dinâmica:

... Mas o que acontece aos desejos de um homem quando há suficiente pão e quando sua barriga está cronicamente cheia?

\footnotetext{
${ }^{16}$ Ele está tratando dos desejos de saber e entender.
} 
Outras necessidades (superiores) emergem ao mesmo tempo e estas dominam o organismo, mais do que a fome fisiológica. E quando estas são satisfeitas por sua vez, novamente novas necessidades (e ainda mais superiores) emergem.

Isto é o que eu quero dizer quando afirmo que as necessidades humanas básicas estão organizadas em uma hierarquia de relativa preponderância. (MASLOW, 1954, p. 83)

Recorde-se o leitor, entretanto, que Maslow aceita a idéia da múltipla motivação, ou seja, que os motivos atuam ao mesmo tempo na pessoa, influenciando-a diferentemente ao mesmo tempo. Assim, a preponderância das necessidades fisiológicas é ilustrada por Maslow em exemplos extremos, em que "o organismo está extremamente e cronicamente faminto ou sedento" (MASLOW, 1954, p. 83) Nesta condição elas preponderariam sobre as demais e chegariam a interferir na visão de mundo e de razão de ser no mundo que os homens constroem.

Maslow não desenvolveu uma teoria mecanicista da hierarquia das necessidades, mas uma teoria da preponderância ${ }^{17}$ hierárquica das necessidades, em que a influência de uma necessidade estaria associada à gratificação relativa de uma necessidade considerada inferior a ela. Trata-se de uma teoria dinâmica, portanto as pessoas se encontrariam sob o jugo das influências das suas necessidades, que se alternam ao longo da vida. Em momento algum Maslow traçou uma teoria articulada a etapas ou fases da vida, como pode imaginar algum leitor apressado ${ }^{18}$. O que Maslow chega a afirmar é a idéia de uma necessidade ser "cronicamente gratificada" (MASLOW, 1954, p. 84), ou seja, de a pessoa ter à sua disposição imediata os meios de

\footnotetext{
${ }^{17}$ Do inglês prepotency.

${ }^{18}$ ROBBINS (1998, p. 110), por exemplo, afirma que "a teoria diria que, embora nenhuma necessidade seja algum dia totalmente gratificada, uma necessidade substancialmente satisfeita não motiva mais. Então se você quer motivar alguém, de acordo com Maslow, precisa entender em que nível daquela hierarquia a pessoa está atualmente e concentrar-se em satisfazer as necessidades daquele nível ou acima dele"
} 
gratificação de sua necessidade. Não é aleatoriamente que esta afirmativa se encontra nas reflexões que Maslow faz sobre as necessidades fisiológicas, cuja gratificação depende menos das outras pessoas que a das necessidades sociais.

O próprio Maslow tratou de relativizar a sua teoria da preponderância das necessidades. Após apresentar a categorização de necessidades, ele discute a fixidez de grau, afirmando o seguinte:

Nós falamos muito de como esta hierarquia possui uma ordem fixa, mas finalmente isto não é tão rígido como nós sugerimos. É verdade que a maioria das pessoas com que temos trabalhado parecem ter as necessidades na ordem que foi indicada. Contudo há várias exceções. (MASLOW, 1954, p. 98)

E entre as exceções, o autor inclui pessoas para quem "a auto-estima é mais importante que o amor", pessoas em que "o impulso à criatividade é mais importante qualquer outro contradeterminante", pessoas em quem o nível de aspiração é permanentemente reduzido, personalidades psicopáticas para as quais parece haver uma perda permanente das necessidades de amor ou pertencimento, situações em que a necessidade foi satisfeita por um longo tempo e passam a ser subestimadas.

Uma exceção considerada por ele a mais importante é a situação que envolve "ideais, altos padrões sociais, altos valores ou similares". Com tais valores as pessoas podem tornar-se mártires, sacrificarem-se em benefício de sua crença particular ou valor. Ele explica essa situação pelo aumento do nível de tolerância à frustração da gratificação de necessidades inferiores.

Maslow teceu considerações sobre a dinâmica da motivação. As necessidades estariam sujeitas à dita "hierarquia de preponderâncias em termo de vontades conscientemente percebidas ou desejos, mais que em termos de comportamentos". 
Um complicador adicional dessa proposição diz respeito às gratificações parciais. Segundo essa idéia, uma necessidade de nível inferior poderia ser parcialmente gratificada, reduzindo-se o seu poder motivador a ponto de se tornar menos influente que necessidades superiores menos gratificadas. Como é bastante difícil mensurar-se, com precisão, níveis de necessidades e de gratificações, essa proposta dificulta ainda mais a operacionalização da teoria da hierarquia das preponderâncias de Maslow, principalmente para grupos ou coletivos de pessoas. O poder explicativo de suas idéias é, na verdade, um poder compreensivo e se circunscreve quase que apenas à clínica individual.

Muitos autores posteriores a Maslow se propuseram a fazer pesquisas empíricas sobre a hierarquia de necessidades, e a maioria deles não encontrou resultados que a sustentassem. Entretanto, seus experimentos foram calcados, em sua maioria, no pressuposto da rigidez da hierarquia, o que, como foi visto, não se coaduna com o pensamento do autor a quem se propuseram avaliar. Neste estudo foram avaliados dois dos oito estudos encontrados em pesquisa na base de dados PROQUEST. Houve alguma dificuldade de recuperação de trabalhos anteriores aos anos 80 , especialmente em periódicos que não faziam parte das coleções das bibliotecas brasileiras, participantes do sistema COMUT. Têm-se, por exemplo, os trabalhos de Schneider, Benjamin, Alderfer, Clayton (1973) e Rauschenberger, Schmitt, Hunter (1980). O primeiro estudo encontrou dados controvertidos em três pesquisas realizadas e os autores creditaram seus resultados à dificuldade de operacionalização dos conceitos de Maslow. O último aplicou o modelo de Markov na análise de respostas do questionário de necessidades ERG de Alderfer, em um estudo longitudinal, mas escolheu uma 
amostra que era reavaliada em intervalos de apenas 10 meses, em três aplicações, o que é bastante inconsistente com as idéias de Maslow, como se mostrou anteriormente.

\subsubsection{O duplo mecanismo das motivações}

Em sua trajetória como pesquisador, Maslow abandonou aos poucos os estudos experimentais de animais, para dedicar-se ao estudo sobre a personalidade de pessoas sadias. Nesta transição, ele foi muito influenciado pelos autores existencialistas norte-americanos. Nessa fase, ele publicou o livro Toward a Psichology of Being ${ }^{19}$, e avançou suas contribuições sobre a teoria da motivação. Deteve-se mais na análise das pessoas auto-atualizantes ou auto-realizadas e propôs um novo mecanismo de gratificação para essas pessoas.

A contribuição adicional ao trabalho de 1954 reside na distinção entre a chamada motivação baseada em deficiência (deficiency motivation) e a motivação para o crescimento (growth motivation).

Por motivação baseada em deficiência, Maslow sintetiza as contribuições de base organicista e fisiológica, que entendem o funcionamento do psiquismo humano com base nos impulsos e instintos. A sede, por exemplo, cria um desconforto no organismo que exige dele a busca e ingestão de água ou substância de propriedade semelhante, até que o mal-estar provocado por sua falta seja diminuído suficientemente. Neste caso, a gratificação reduz o desconforto, que é o agente motivador do comportamento humano. Os autores contemporâneos a Maslow já haviam sofisticado este arranjo teórico e proposto a teoria da homeostase, que compreende a redução da

\footnotetext{
${ }^{19}$ Traduzido para o português com o título "Introdução à Psicologia do ser', publicado pela editora Itatiaia.
} 
tensão a um nível ótimo (e não até a eliminação total do desconforto, o que Maslow denominou de teoria do descanso ${ }^{20}$ ).

Ao estudar pessoas consideradas auto-atualizantes, Maslow observou, entretanto, que essas pessoas não apenas continuavam desejantes, como havia uma singular diferença no papel de sua gratificação, na dinâmica motivacional.

Em tais pessoas a gratificação aumenta em vez de diminuir a motivação, amplia em vez de diminuir a excitação. Os apetites se tornam intensificados e aumentados. Eles crescem por si mesmos, em vez de desejarem menos e menos, e a pessoa deseja mais e mais, por exemplo, educação. Em vez de buscar o descanso, a pessoa se torna mais ativa. ... O crescimento é, por si mesmo, um processo recompensador e excitante, por exemplo, a realização dos desejos e ambições, como ser um bom médico, a aquisição de habilidades admiradas, como tocar um violino ou ser um bom carpinteiro, o pronto aumento da compreensão sobre pessoas ou sobre o universo, ou sobre si-mesmo, o desenvolvimento da criatividade em qualquer campo ou, o mais importante, simplesmente a ambição de ser um bom ser humano." (MASLOW, 1998, p. 36)

Esta distinção gerou implicações para a análise clínica da saúde-doença, e ele desenvolveu uma diferenciação de espécies de prazer. Para o prazer causado pela gratificação de motivos baseados em deficiência, a gratificação do desejo gera um platô de sereno alívio de tensão e "falta de motivação". Na situação em que opera a motivação para o crescimento não há clímax ou consumação, não há momento orgásmico, não há estado-fim, e "nenhum objetivo pode ser definido climaticamente". O crescimento é um estado que nunca pode ser satisfeito porque quanto mais tem, mais deseja a pessoa.

Outra diferença marcante entre as motivações é que, enquanto a motivação baseada em déficit pertence à espécie, ou seja, todas as pessoas possuem, a motivação para o crescimento é idiossincrática, diferente de pessoa para pessoa.

As metanecessidades são igualmente poderosas entre si, em média, isto é, eu não consigo detectar uma hieraquia generalizada de preponderância, mas em qualquer indivíduo dado, ela pode existir e freqüentemente são

\footnotetext{
${ }^{20}$ Do inglês theory of rest.
} 
hierarquicamente arranjadas de acordo com os talentos idiossincráticos e as diferenças constitucionais. (MASLOW, 1993, p. 312-313)

As diferenças de mecanismo justificam o fato de Maslow denominar a motivação para o crescimento de metamotivação e as necessidades em jogo nesta última categoria, de metanecessidades.

Como as pessoas auto-realizadas geralmente estão menos dependentes da motivação baseada em deficiência, elas se tornam mais independentes do meioambiente e das opiniões dos outros, e tornam-se mais autodirigidas. Maslow tece considerações em seu trabalho, mostrando como esta diferença afeta outras áreas da personalidade, como as relações interpessoais, interessadas ou desinteressadas, a dependência ou transcendência do ego, a aprendizagem, a percepção e a necessidade de amor.

Essa distinção fez com que o autor passasse, daí em diante, a analisar seus fenômenos tendo em vista se as pessoas são principalmente motivadas com base em deficiências (motivadas D), se são motivadas com base em crescimento, ou motivadas pelo ser (motivadas $\mathrm{S}$ ). Sempre que se refere a uma faculdade humana, ele a relativiza com base na dinâmica subjacente, ou seja, cognição $\mathrm{S}$ e cognição $\mathrm{D}$, amor $\mathrm{S}$ e amor $\mathrm{D}$, etc.

No núcleo das metanecessidades estão os valores do ser (valores S), que Maslow entende serem os mobilizadores das pessoas auto-realizadas.

Maslow (1998, p. 173) percebe que está fazendo inferências lógicas com base em suas pesquisas e entende que são necessárias novas pesquisas para confirmação de suas afirmações, especialmente no que se refere ao conceito de homem autorealizado. 
A partir dessa distinção, o postulado da hierarquia das necessidades, embora mantido com restrições, vai ganhar um papel secundário no trabalho de Maslow, que entende ser mais importante demarcar bem as diferenças entre as pessoas autorealizadas e as pessoas motivadas com base em deficiências.

\subsubsection{Valores S e metanecessidades}

O conceito de metanecessidades tem por base a idéia de que as pessoas que vivem em condição de gratificação de suas necessidades básicas têm em vista uma preocupação com o que Maslow denomina serem os Valores S.

Estes valores seriam: "verdade, beleza, justiça, perfeição" (MASLOW, 2001, p. 50) "integração, unificação e tendência em direção à unidade" (MASLOW, 2001,p. 171); “ordem" (MASLOW, 2001, p. 181) entre outros. As pessoas prezam e se aproximam dos valores S em sociedades onde há sinergia (MASLOW, 2001, p. 152). Neste ponto, suas reflexões se tornam muito especulativas, como quando ele afirma que os valores S são consistentes entre si, ou seja, "a verdade é bela", "a beleza é verdadeira", etc. (MASLOW, 1993, p. 313)

Ele afirma que os valores $\mathrm{S}$ podem ser tratados como uma "metanecessidade humana", um tipo particular de motivação mais alta, sujeita à geração de contramotivações e contravalores, como o medo. Neste nível de motivação, ele faz uma clara tentativa de articulação entre a psicopatologia e a dinâmica da motivação. A autoatualização parece ter fronteiras com o medo patológico, as ansiedades e os escrúpulos, que funcionam como uma espécie de resistência do sujeito à influência de suas metanecessidades. 
As pessoas que são propelidas pelas necessidades superiores valorizam cada vez mais a oportunidade de serem criativas e autônomas em seu trabalho. Maslow denominou essa idéia de "metapagamento" 21 . Mas há que se entender que a noção de trabalho que Maslow usa, muitas vezes entre aspas, envolve atividades que nada podem ter a ver com o trabalho remunerado em organizações do Mercado ou Estado. O trabalho da dona de casa e chefe do clã familiar é tomado como exemplo por Maslow quando ele quer explicar a dinâmica da motivação $S$.

Outra explicação importante para a dinâmica da motivação de pessoas autorealizadas é que elas passam a se identificar com o "trabalho" ou qualquer outra forma de ação associada aos valores S. Isso faz com que os sistemas de recompensas sejam percebidos de forma diferente por essas pessoas. Como elas se acham gratificadas e são motivadas com o próprio resultado do trabalho, que é uma forma de concretização dos valores que a "metamotivam", elas passam a não mais realizar as atividades para obter as recompensas concretas, que virão satisfazer suas necessidades de deficiência ("cenouras", como diria Taylor). As recompensas passam a ser referências no mundo concreto, sinais da ação mobilizada pelos valores S. O trabalho pode ser um "prazer superior" (MASLOW, 1993, p. 19) e uma forma de reconhecimento do próprio self (simesmo).

Neste nível a dicotomização entre trabalho e lazer é transcendida; salários, hobbies, férias, etc., devem ser definidos em um nível superior. (MASLOW, 1993, p. 293)

\footnotetext{
${ }^{21}$ Do inglês metapay.
} 


\subsubsection{Motivação e trabalho}

Em 1969, Maslow publicou um livro chamado "Administração Eupsíquica" onde ele tece considerações, às vezes diretamente, outras vezes indiretamente, ao tema do trabalho. Este livro, infelizmente, não é um desenvolvimento sistemático com base em pesquisa para as suas idéias, mas uma espécie de seleção de reflexões breves, escritas em um diário de campo. Neste, são tratados temas diversos, como a liderança, valores, poder, psicopatologia, entre outros, tendo em vista o esforço de implantação de propostas administrativas, cunhadas sob a influência de suas teorias. Deter-se-á aqui, principalmente, nas suas contribuições à teoria de motivação.

Algumas idéias de Maslow foram usadas como base para o desenvolvimento das teorias de McGregor, como se encontra em Hoffman (1988). O sucesso do trabalho deste autor do Massachussets Institute of Technology difundiu o interesse pela leitura da teoria das necessidades no meio empresarial.

Hoffman (1988) publicou uma entrevista realizada com Maslow na qual este destaca algumas das idéias voltadas à atividade laboral. Ele afirma que a empresa de computadores californiana NLS (Non Linear Systems) incentivou o uso da criatividade, cooperação e autodirecionamento dos empregados; investiu em treinamento e desenvolvimento no trabalho e criou times de trabalhadores que definiam per si suas atividades e agenda diária. Esta empresa criou também o cargo de "vice-presidente de inovação".

Maslow acompanhou o desenvolvimento deste projeto com reservas. Hoffman (1988, p. 81) transcreveu algumas de suas anotações à época, nas quais ele afirmava que: 
Eles as estão tomando ${ }^{22}$ como uma verdade bíblica, sem qualquer avaliação real de sua confiabilidade ou validade. A transposição da clínica para o trabalho é realmente um passo gigantesco e trôpego, mas eles seguem à frente com entusiasmo e otimismo... como se todos os fatos fossem e estivessem já comprovados.

Essa experiência foi a base principal para o desenvolvimento do livro já citado. A visão de trabalho que Maslow desenvolveu baseia-se no conceito de sinergia proposto por Ruth Benedict, no qual a cooperação recompensa e cria vantagem para todos os envolvidos.

Maslow tece considerações sobre o envolvimento das pessoas com o próprio trabalho, especialmente aquelas que considera auto-realizadas. Ele afirma que:

...Elas eram metamotivadas por metanecessidades (valores $\mathrm{S}$ ) expressas em sua devoção, dedicação e identificação com algum trabalho grandioso e importante. (MASLOW, 1974, p. 6)

Para ele o trabalho auto-realizador é "uma busca e um preenchimento do self", ao mesmo tempo em que se atinge um estado de perda de si-mesmo. A identificação de uma pessoa com "causas importantes ou trabalhos importantes" amplia o self e a torna importante. Maslow emprega um conceito psicanalítico, a introjeção, para mostrar como o trabalho auto-realizador é assimilado à identidade ou ao self de uma pessoa.

Maslow avaliou as propostas administrativas de Drucker como aplicáveis apenas em uma situação em que os envolvidos tivessem satisfeito suas necessidades básicas no passado, e se pergunta como seria a gestão de pessoas insatisfeitas nos mais diferentes aspectos das suas necessidades básicas. Outra crítica que ele dirige aos modelos de gestão propostos por este autor é que eles pressupõem "boas condições e boa sorte" e uma alta proporção de leis e organizações sinérgicas. Maslow afirma que talvez esses pressupostos fossem válidos para a realidade americana àquela época, mas

\footnotetext{
${ }^{22}$ As idéias de Maslow.
} 
que são passíveis de regressões, situações socioeconômicas em que não se pudessem satisfazer as necessidades das pessoas, portanto, seriam inaplicáveis.

Assim, Maslow recomenda cuidado na aplicação dos princípios da administração eupsíquica. As forças que tendem para a regressão seriam a "escassez de bens, a cessação das gratificações das necessidades básicas preponderantes, ou uma ameaça de cessação, leis ou organização anti-sinérgica, qualquer coisa que aumente o medo ou a ansiedade, perda ou separação de qualquer tipo para a pessoa, que a leve à aflição ou a uma perda, mudanças para pessoas propensas à ansiedade, má comunicação, suspeita, desonestidade, vulgarização da verdade, confusão entre verdade e mentira, etc."

Entendendo que o mesmo homem que participa e colabora pode vir a se revoltar contra condições sociais e de trabalho que não lhe propiciem a gratificação de suas necessidades básicas, ele propõe a seguinte questão de pesquisa: "Como podemos evitar as situações industriais que denigrem a dignidade humana e a tornam menos possível? Em situações inevitáveis na indústria, como as linhas de montagem, como se pode descontaminá-las de forma a manter a dignidade do trabalhador e sua auto-estima, tanto quanto possível, dadas as circunstâncias?” (MASLOW, 1974, p. 52)

Maslow, entretanto, não via a melhora das relações de trabalho como uma panacéia para os problemas da empresa. Hoffman (1988, p. 82) cita o seguinte comentário:

"Se o que eles produzem não é bom, então a administração iluminada irá destruir toda a empresa, da mesma forma que a verdade destrói a falsidade e a vilania..."

Outro ponto das conferências que Maslow fazia destacado com propriedade por Hoffman é que as pessoas possuem diferentes necessidades de motivação. Segundo 
ele, alguns empregados não pretendem se auto-realizarem no ambiente de trabalho, preferem fazê-lo em outro espaço social. Forçar a idéia de realização pelo trabalho, alinhando-a aos objetivos de alguma empresa em particular, pode gerar resistência e indignação.

O autor era bastante precavido com a transposição que se fazia dos seus conceitos para a experiência laboral, o que se pode demonstrar com o comentário que ele fez com relação à noção de auto-realização, após dizer que esta noção possui suporte empírico na experiência psicoterápica de autores como Rogers e Fromm:

Isto, é claro, leva ao problema de se transpor da situação terapêutica à situação industrial, o que ainda está aberto à verificação. Precisa ser validado como uma transposição legítima. (MASLOW, 1974, p. 56)

Maslow emprega o conceito de metanecessidades para refletir sobre a vida das pessoas nas organizações e propõe que se atente às queixas ${ }^{23}$ que as pessoas fazem. Segundo ele, elas seriam uma espécie de bom indicador do nível de gratificação de necessidades. Um exemplo dado para esta proposta foi a formação de uma comissão de senhoras para reclamarem e pressionarem o poder público com relação às flores usadas nos jardins e canteiros de uma cidade norte-americana. Ele argumenta que se essas senhoras podem se dar ao luxo de se queixarem do estado de beleza de sua cidade é porque temas como a criminalidade, a fome e o acesso ao trabalho já não mais seriam percebidos como problema por este grupo social.

Por essa razão, ele considera utópica a meta de um administrador que pretendesse o fim das reclamações dos trabalhadores de sua empresa, mas orienta-o a avaliar em que nível de gratificação essas queixas predominam.

A reclamação de alto nível não deve ser considerada uma reclamação comum; deve ser usada para indicar todas as pré-condições que foram satisfeitas para tornar a reclamação possível. (MASLOW, 2001, p. 313)

\footnotetext{
${ }^{23}$ Do inglês grumbles
} 
Com este artifício, Maslow estaria propondo critérios para análise de pesquisas de satisfação do trabalho, com base em sua teoria hierárquica.

\subsubsection{Reflexões críticas da teoria de motivação de Maslow}

O conceito de necessidade desenvolvido por Maslow possivelmente levou alguns autores a afirmarem que a motivação é interna, ou seja, pertence ao mundo íntimo da pessoa, entretanto, há que se considerar que ela se acha articulada ao mundo exterior (onde se encontram os objetos de satisfação dos desejos) e mediada pela consciência (de si e do outro) e pelas relações sociais, ou seja, não é possível falar-se em gratificação sem considerar-se a inserção e relacionamento humano no mundo social. $\mathrm{O}$ autor norte-americano, entretanto, ainda que tentando desenvolver uma visão complexa de homem, teoriza sobre a motivação como se esta fosse uma espécie de energia interna da pessoa, sobre a qual se pode fazer uma espécie de Física da motivação.

O problema que emerge desta visão de motivação e que contamina a teoria de Maslow é que, ao definir um conceito geral de motivo e tentar descrever "padrões de funcionamento" dos motivos no homem, ele não irá conseguir sustentar a aplicação de conceitos como a homeostase de Cannon aos motivos culturais. É empiricamente fácil associar fenômenos orgânicos a alterações do organismo, mas Maslow não conseguiu fundamentar empiricamente sua proposta da dinâmica individual dos fenômenos culturais. Ao mesmo tempo em que ele consegue observar claramente que a dinâmica da motivação não se reduz ao nível biológico do humano, como se vê na citação abaixo, ele parece insistir em propor uma dinâmica geral que reduz o fenômeno cultural à dinâmica biológica sem base em evidências empíricas. Em outras palavras, não se sabe o que leva Maslow a crer que a auto-estima, por exemplo, é uma necessidade, cuja 
privação a torna central no mundo íntimo das pessoas e mobilizadora de seu comportamento?

Se aceita esta crítica, há implicações na sustentação da teoria hierárquica da preponderância de necessidades. Mesmo com as concessões e relativizações feitas por Maslow, ou ainda, uma vez feitas essas concessões, pode-se postular a existência de uma hierarquia de preponderância de necessidades, válida para a maioria das pessoas de um grupo social? Esta controvertida questão continua sem suporte empírico ou fenomenológico, quase meio século após a sua proposição.

Se não se encontram regularidades, as idéias de Maslow não podem ser empregadas como um princípio apriorístico para se fazerem recomendações de políticas de gestão, seja no âmbito social, seja no âmbito organizacional. Esta afirmativa contundente possivelmente seria aceita pelo próprio Maslow, que se mostrou cuidadoso com o status de verdade de suas idéias, o que se pôde constatar na leitura de seus biógrafos e de seu "administração eupsíquica".

Há que se valorizar, entretanto, a sua contribuição para que se tenha uma visão de homem mais abrangente que a proposta por Taylor ou pelos autores clássicos de microeconomia. Se não existe preponderância de necessidades, portanto, não cabe tentar cunhar uma imagem piramidal que alguns autores insistem em utilizar, há que se pensar em um homem que lida com múltiplos anseios, capazes de o mobilizarem, nas diferentes instâncias sociais da vida: a organização laboral, a família e a vida em sociedade.

A atenção dada pelo autor, em sua segunda fase, aos valores $\mathrm{S}$ e à construção de uma segunda dinâmica da motivação, articulada ao processo de identificação do self, parece ser um bom começo para o entendimento de fenômenos como a motivação do 
trabalhador voluntário. Ele permite que se distinga inicialmente o voluntário identificado ou metamotivado, do voluntário instrumental, aquele que tem em vista alguma recompensa concreta não financeira em seu trabalho (a realização de um estágio que o permita adquirir experiência para a vida profissional, a incorporação de um registro curricular, a aproximação à pessoas que podem ser futuramente úteis, etc.).

Outra contribuição do pensamento de Maslow repousa no repúdio em se transformar o lugar de trabalho na instância por excelência de gratificação dessas necessidades, ou no espaço privilegiado de realização das pessoas. Isto demanda que os gestores escutem e compreendam as pessoas com quem trabalham, entendendo qual é o papel da atividade laboral e da organização em que se encontram para suas vidas, e aceitem, portanto, o desafio de administrar pessoas com diversidade tanto de trajetórias como de aspirações para a vida.

\subsection{A motivação estudada por David McClelland}

David Clarence McClelland foi um prolífico professor norte-americano, que doutorou-se em Psicologia na Yale University em 1941. Ele iniciou sua carreira na Wesleyan University onde desenvolveu uma linha de estudos sobre motivação que se expandiu e foi empregada no entendimento do trabalho humano. Em 1963, ele fundou uma consultoria denominada $M c B e r$, voltada ao treinamento e desenvolvimento de gerentes. Ingressou em Harvard em 1956 e na Boston University em 1987, tendo falecido aos 80 anos em $1998 .^{24}$

\footnotetext{
${ }^{24}$ Cf. The Harvard University Gazette, 1998.
} 
De tendência universalista, McClelland invadiu os campos das Ciências Sociais, da Economia e da Biologia em busca da recuperação das diferentes visões que se tinha do conceito de motivação.

Como o presente trabalho focaliza-se na tentativa de resgatar a trajetória da construção do conceito de motivação e de sua aplicação ao mundo do trabalho, foram revistos cinco livros nos quais o autor apresenta as bases e as pesquisas relacionadas ao tema em questão.

O primeiro foi originalmente publicado em 1951 (MCCLELLAND, 1967) e denominou-se Personality. Nele se encontram as principais informações sobre a sua visão de homem e de mundo e dá uma atenção especial ao tema da motivação.

O segundo foi intitulado The Achievement Motive ${ }^{25}$ e contém uma revisão das teorias de motivação para as principais vertentes da Psicologia norte-americana (principalmente as escolas comportamental e cognitivista) e justifica suas escolhas e proposta teórico-metodológica. Nele já se observa uma influência marcante de autores de Harvard, da psicologia social americana e da psicologia clínica.

Em 1955, ele organizou uma coletânea de artigos denominada Studies in Motivation. Neste trabalho estão agrupados os estudos motivacionais, a partir dos seguintes critérios: estudos sobre a psicodinâmica da motivação (que inclui motivos conscientes e inconscientes), origens biológicas dos motivos (instintos) e origens sociais dos motivos (que inclui valores de base econômica, a estrutura familiar como origem de motivos, padrões culturais como fonte de valores e a religião também como fonte de valores).

\footnotetext{
${ }^{25}$ O motivo de realização, publicado em 1953.
} 
Posteriormente, seus estudos de motivação se aproximam do entendimento do mundo do trabalho. As perguntas, inicialmente gerais, vão se tornando mais e mais específicas, possivelmente como uma decorrência dos trabalhos que ele realizou para o Comittee on Identification of Talent, ainda nos anos $50 .^{26}$

Em 1961, ele publica The achieving society ${ }^{27}$, que traz, como pergunta central, qual seria o papel da necessidade de realização no desenvolvimento econômico de uma sociedade e em uma empresa.

Como os resultados de sua pesquisa fossem contraditórios, ele avança em seu trabalho e publica o livro Power: the inner experience, em 1975, em que se detém na necessidade de poder como fator importante para o entendimento da motivação dos gerentes e dos empreendedores.

Sua teoria de motivação pode ser classificada como situacionista-empirista a partir do quadro de Muchielli (1981), devido à importância do ambiente e da aprendizagem dada pelo autor a este fenômeno.

4.2.1 Um modelo de interação entre a personalidade e o ambiente

A compreensão do papel da motivação na relação entre o indivíduo (o autor prefere este conceito ao de personalidade) e o ambiente é bastante facilitado se se considerar o modelo abaixo que McClelland desenvolveu após a sistematização dos estudos de motivação.

\footnotetext{
${ }^{26}$ Alguns dos trabalhos deste comitê foram publicados no livro "Talent and Society", cuja primeira edição ocorreu em 1958.

${ }^{27}$ Traduzido para o português sob o título "A Sociedade Competitiva: Realização e Progresso Social”, em 1972.
} 
Como empirista, ele deseja ser capaz de predizer o comportamento humano, embora esteja consciente da dificuldade desse empreendimento, e aceite que, na prática, o que melhor se pode fazer é explicá-lo a posteriori $^{28}$, pela sua complexidade em situações não experimentais (em campo).

McClelland (1967, p. 595) entende que o comportamento pode ser explicado segundo a fórmula abaixo:

\section{$\mathbf{C}=\mathbf{f}(\mathbf{P}, \mathbf{M})$}

Onde $\mathbf{C}$ é o comportamento humano,

P são os elementos da personalidade e

M são os elementos do meio ambiente.

Considerando como um pseudoproblema o debate oriundo do século XIX entre os ambientalistas e os humanistas, McClelland se torna depositário das contribuições de psicólogos e de sociólogos do século XX, e destaca três conceitos para o desenvolvimento de seu modelo teórico: os traços, os esquemas e os motivos. Ele os integra da seguinte forma:

${ }^{28}$ MADSEN, 1967, p. 236. 


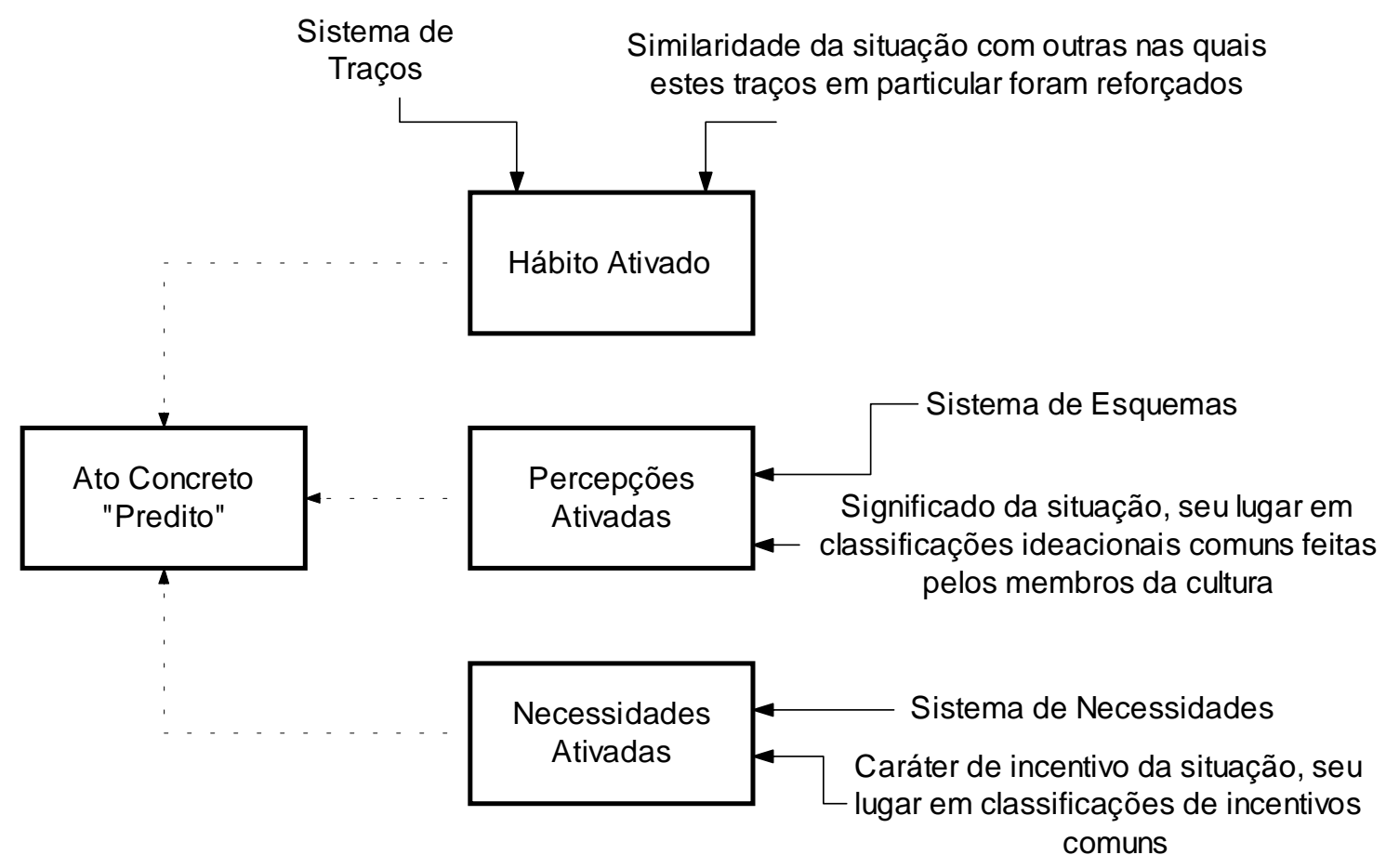

Figura 6: Interação entre personalidade e ambiente, mostrando predição de comportamento Fonte: MCCLELLAND, 1967, p. 595

A construção da noção de traço deu-se a partir da revisão dos estudos sobre o tema em sua época, incluindo autores como Allport, Cattell e Murray. Estes autores definem traços como "consistências no comportamento", ou seja, reações semelhantes das pessoas em ocasiões similares, mas divergem quanto à forma de se construir uma relação de traços que permita a operacionalização do conceito. McClelland analisou as diferentes listagens de traços e concluiu que elas não devem ser baseadas em normas ou em expectativas sociais, devido à fragilidade da covariância desses tipos de traços no comportamento individual. Ele afastou também a formulação de listas de traços, a partir de objetivos individuais e pretendeu, então, construir seu próprio modelo teórico a partir da noção de "similaridades ou recorrências dos padrões de resposta". Sua definição ficou da seguinte forma: 
Um traço é a tendência aprendida de um indivíduo reagir como ele reagiu de forma mais ou menos bem sucedida no passado, em situações similares, quando motivado de forma similar. (MCCLELLAND, 1967, p. 216)

O segundo ponto de seu modelo teórico para o estudo da personalidade envolve a análise das relações entre cultura e indivíduo. Para isso criou um modelo complexo, transcrito na figura 7.

Com essa proposta, McClelland quer responder à seguinte questão: como os padrões culturais são assimilados, e o que acontece com eles no processo de assimilação?

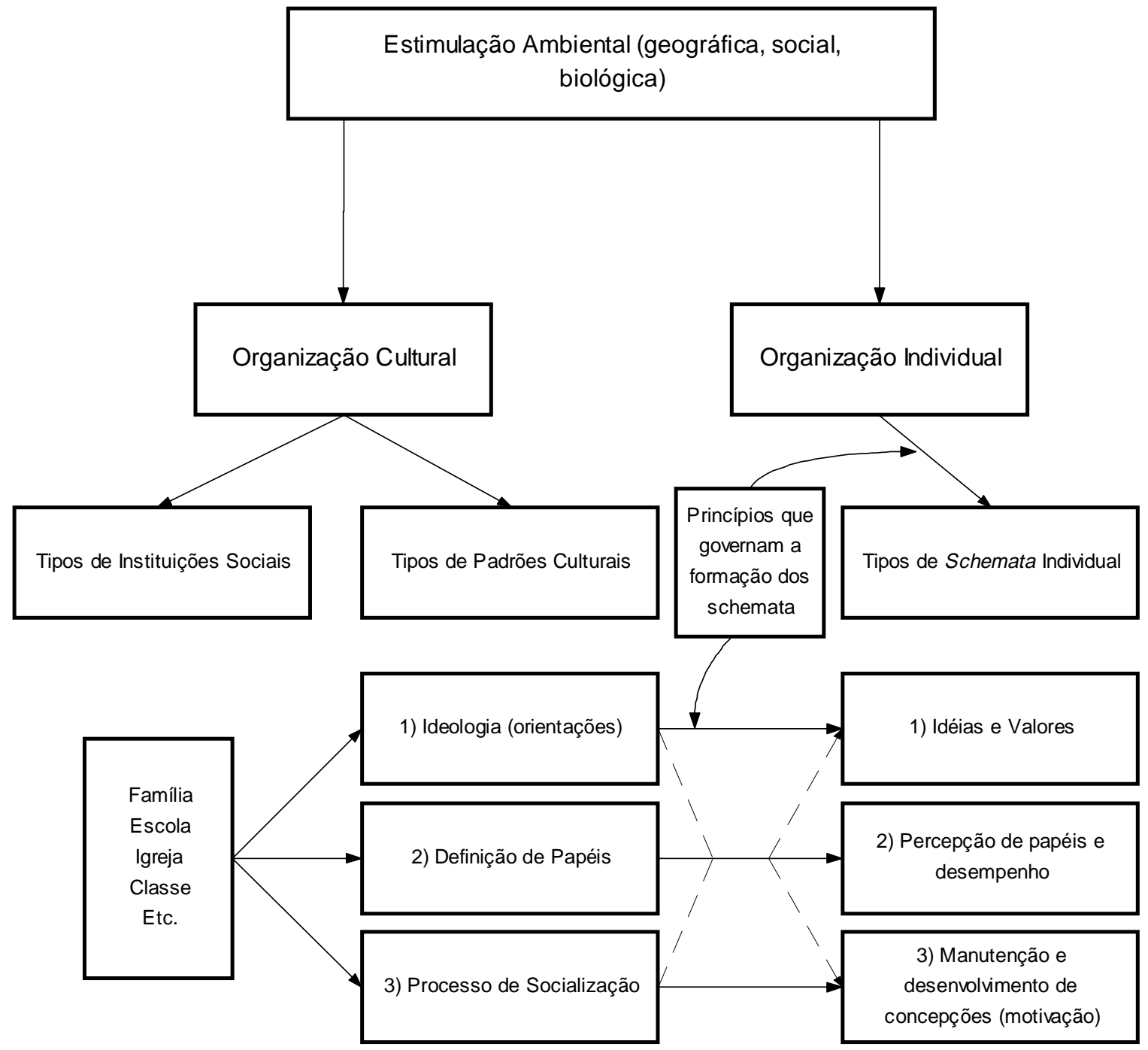

Figura 7: Apreensão da cultura pelo indivíduo, segundo McClelland. 
Por schemata (esquema ou esquemas), também chamado de mapa $\operatorname{cognitivo}^{29}$ ele entende o fruto da organização da experiência pelo indivíduo, organização esta "mais simples que a original". Esse schemata seria construído gradualmente e é constantemente modificado pelo sujeito que, por sua vez, não tem consciência desse processo de construção. Origina-se na experiência pessoal do indivíduo, mas sua principal fonte são os esquemas sociais (social schemata), que são “organizações da experiência que já foram trabalhadas ${ }^{30}$ pela cultura em que a pessoa vive e que lhe são comunicadas pelos membros daquela cultura". ${ }^{31}$ McClelland entende que há duas formas de se mensurar os schemata: inferindo a sua existência a partir dos julgamentos feitos por uma pessoa ou fazendo uma análise introspectiva dos seus relatos fenomenológicos.

O autor se detém em três núcleos da análise da influência dos padrões culturais: a ideologia, os papéis e o processo de socialização.

O conceito de ideologia é tomado da sociologia estrutural-funcionalista e pode ser definido como um conjunto de premissas que explicitam a visão de mundo de um dado grupo social.

A noção de papel é tomada da teoria de Linton, e seria "um agrupamento de padrões de comportamento que servem como solução culturalmente normal ou modal para problemas sociais usuais, recorrentes, peculiares a status particulares ou posições na sociedade" ${ }^{, 32}$. McClelland identifica o status do indivíduo a partir das categorias idade, sexo, posição na família, ocupação e associações das quais o indivíduo se torna

\footnotetext{
${ }^{29}$ MCCLELLAND, 1967, p. 242

${ }^{30}$ Do inglês work out.

${ }^{31}$ MCCLELLAND, 1967, p. 254

${ }^{32}$ MCCLELLAND, 1967, p. 293.
} 
membro. O professor de Harvard sustenta a distinção entre a percepção de papéis e o desempenho de papéis pelos indivíduos, avaliando-os em termos de ajustamento social.

O processo de socialização, ou seja, como o indivíduo se torna membro da sociedade onde vive, é tratado apenas do ponto de vista da infância, ou do "treinamento infantil", porque esse processo é visto como a origem primária dos schemata e dos motivos. McClelland lança mão dos estudos de cientistas sociais em tribos indígenas e dos estudos psicanalíticos (Freud, Kardiner, etc.). Ele não nega os processos de socialização secundária, mas não os desenvolve no livro citado.

Dos padrões culturais aos schemata individuais, há uma diferença. Os padrões culturais não são, portanto, uma espécie de forma que determina os mapas conceituais individuais, mas influências que exigem do indivíduo algum tipo de elaboração.

O terceiro ponto da teoria de personalidade de McClelland é a motivação, cujo conceito foi elaborado a partir de uma extensa revisão de literatura e culmina em uma proposta alternativa aos modelos herdeiros da noção de instinto. Pode-se afirmar que o autor trabalha em uma perspectiva culturalista da motivação, como se verá posteriormente. Suas diferenças teóricas com a noção de motivação da psicanálise são ilustradas com o exemplo abaixo, que esclarece bem qual é o papel dos motivos na dinâmica do indivíduo:

Um homem se torna um cirurgião não apenas por causa de alguma necessidade subjacente, mas também por causa das suas concepções de como é a vida de um cirurgião, ou do que é exigido dele no serviço aos outros (schemata), e por causa dos seus ajustamentos passados a situações similares (traços de controle emocional, etc.). Necessitamos também das variáveis traço e esquema, assim como da variável motivação para explicar qualquer escolha particular como esta. (MCCLELLAND, 1967, p. 479).

McClelland sintetiza sua teoria da personalidade nestes três pilares cuja articulação está bem clara na seguinte frase: 
A psicologia dos traços foi desenvolvida para explicar as respostas recorrentes e as consistências no comportamento, a fim de explicar o como do comportamento. O conceito de esquema ou atitude foi desenvolvido para lidar com o problema de o que as pessoas sabiam ou quais eram os conteúdos simbólicos de suas mentes. O conceito de motivo foi desenvolvido em resposta à questão por que. Por que as pessoas se comportam da forma que o fazem? (MCCLELLAND, 1967, p. 383)

4.2.3 A trajetória dos estudos de motivação.

McClelland (1953) identificou quatro grandes teorias sobre a motivação na Psicologia norte-americana: o modelo sobrevivencialista, o modelo da intensidade do estímulo, o modelo do padrão de estímulos e o modelo da emergência de afetos, como se vê no quadro três: 
Quadro 3: Síntese dos modelos de motivação

\begin{tabular}{|c|c|c|}
\hline Fontes Possíveis da Motivação & Motivos & $\begin{array}{l}\text { Como ele se reflete nos tipos de } \\
\text { comportamento }\end{array}$ \\
\hline $\begin{array}{l}\text { 1. Necessidades de Sobrevivência } \\
\text { Biologicamente Determinadas }\end{array}$ & "Modelo Sobrevivencialista" & $\begin{array}{l}\text { Respostas adaptativas que } \\
\text { permitem ou promovem a } \\
\text { sobrevivência (redução de } \\
\text { necessidade) }\end{array}$ \\
\hline 2. Intensidade de Estímulo & $\begin{array}{l}\text { "Modelo da Intensidade do } \\
\text { Estímulo" }\end{array}$ & $\begin{array}{l}\text { a) Aumenta a apresentação de } \\
\text { respostas } \\
\text { b) Melhora o desempenho } \\
\text { (aprendizagem) }\end{array}$ \\
\hline $\begin{array}{l}\text { 3. Padrões particulares de } \\
\text { estímulos } \\
\text { Situações-estímulo que evocam } \\
\text { graus variáveis de } \\
\text { correspondência entre a } \\
\text { expectação e a percepção } \\
\text { Situações-estímulo que evocam } \\
\text { tendências de respostas } \\
\text { incompatíveis que produzem } \\
\text { frustração }\end{array}$ & $\begin{array}{l}\text { "Modelo dos Padrões de Estímulo } \\
\text { Particulares" }\end{array}$ & $\begin{array}{l}\text { Padrões de Resposta } \\
\text { Direção do comportamento } \\
\text { organizada relacionada a uma } \\
\text { série de atos } \\
\text { Padrões de resposta distintivos } \\
\text { medidos no cérebro através de } \\
\text { efeitos autonômicos no } \\
\text { comportamento aberto }\end{array}$ \\
\hline $\begin{array}{l}\text { 4. Sinais emparelhados com } \\
\text { discrepâncias de nível de } \\
\text { adaptação que produzem afetos } \\
\text { de forma inata }\end{array}$ & "Modelo da Emergência Afetiva" & $\begin{array}{l}\text { Livre escolha orientada por } \\
\text { objetivos com hábito e fatores } \\
\text { situacionais minimizados, } \\
\text { conhecidos ou aleatórios. } \\
\text { a) Evitação da abordagem sob as } \\
\text { condições acima } \\
\text { b) Freqüência com a qual as } \\
\text { classes de pensamentos } \\
\text { orientados por objetivos (Rs) são } \\
\text { escolhidos para inclusão na } \\
\text { fantasia }\end{array}$ \\
\hline
\end{tabular}

Fonte: MCCLELLAND, 1953, p. 14.

O modelo sobrevivencialista deve este nome à influência das teorias evolucionistas da Biologia. Ele trata os motivos humanos como necessidades biológicas, "sinais inatos, que avisariam o organismo humano das ameaças à sobrevivência" (MCCLELLAND, 1953, p. 9). O autor abandona essa teoria a partir da crítica que faz aos seus postulados. Ele mostra que há necessidades biológicas que não motivam o comportamento dos organismos (como é o caso do déficit de vitamina B12), relata situações em que o organismo reage de forma contraditória a estímulos externos (choque anafilático) e entende que essa teoria diminui bastante a importância da 
percepção dos animais inferiores no direcionamento do próprio comportamento, e cita um de seus trabalhos no qual ele mostra que os motivos aprendidos, como a realização, são extraordinariamente persistentes e poderosos, se comparados com motivos biológicos, bem como da fragilidade dos argumentos que afirmam que se podem reduzir esses motivos às necessidades biológicas. Nesta crítica, McClelland se afasta de uma perspectiva baseada em instintos ou pulsões da motivação, sem, entretanto, negar a sua existência.

O modelo da intensidade do estímulo desloca o objeto da motivação do interior do organismo para o ambiente. Os impulsos ${ }^{33}$ são vistos como "estímulos fortes que impelem ação". De arcabouço comportamental, essa teoria entende que qualquer impulso pode se tornar motivador se for "suficientemente intenso". Mais uma vez McClelland faz inúmeras referências a pesquisas de comportamento animal nas quais a estimulação intensa não gera comportamentos, nem sempre produz motivação, e que pode, quando muito, ser considerada como uma condição antecedente para o motivo, mas não se pode confundir um motivo com um estímulo. (MCCLELLAND, 1953, p. 20) O que se observa é que McClelland critica as propostas exclusivamente comportamentais.

O modelo do padrão de estimulação seria a alternativa às críticas do modelo da intensidade do estímulo. Esse modelo é uma alternativa mais cognitivista, mas ainda comportamentalista, para o estudo das motivações. Hebb (apud MCCLELLAND, 1953) define motivação referindo-se “(1) à existência de uma sequiência de fases organizadas, (2) à sua direção ou conteúdo, e (3) à sua persistência em uma dada direção, ou estabilidade de conteúdo”. (MCCLELLAND, 1953, p. 22)

\footnotetext{
${ }^{33}$ Do inglês drive.
} 
Este modelo tem como elementos críticos a percepção e a expectação do sujeito, mas gera um problema grave com relação ao caráter ontológico dos motivos. Ele identifica os motivos a partir dos cursos de ação supostamente derivados dele, o que cria problemas, quando se desconsidera uma emoção como o medo, para focalizar-se apenas nos padrões de aprendizagem que um animal desenvolve. McClelland critica intensamente esse deslocamento das emoções para os seus efeitos motores ou fisiológicos (criticando desta forma a abordagem comportamental).

O modelo da emergência dos afetos é o reduto para onde este pesquisador se retirou após as críticas feitas às abordagens anteriores. Ele define motivo como "uma forte associação afetiva, caracterizada por uma reação objetiva antecipatória e baseada em uma associação que passa de certos sinais a prazer ou dor"34 Com esta definição, o autor consegue um conceito de base empírica, capaz de resolver os problemas que ele propôs à noção ambiental dos behavioristas e ainda capaz de justificar algumas contribuições psicanalíticas ao tema, especialmente a noção de inconsciente e a importância da primeira infância na construção da personalidade. Outra pretensão do modelo deste autor é a de articular algumas das contribuições de cientistas sociais estrutural-funcionalistas (como Parsons, por exemplo) e a noção de cultura ao tema da motivação.

4.2.4 Da literatura clínica aos postulados sobre a motivação

Além das contribuições comportamental e cognitivista, ele reviu as principais idéias de origem em pesquisas da psicologia clínica. Em leitura rápida de Freud, ele identificou os seguintes princípios "psicanalíticos” da motivação:

\footnotetext{
${ }^{34}$ MCCLELLAND, 1955a, p. 226.
} 
a) todos os comportamentos são motivados;

b) os motivos são persistentes;

c) os motivos são freqüentemente inconscientes, desconhecidos para o sujeito;

d) a motivação é essencialmente tensional em seu caráter;

e) há um motivo, a libido, que responde por todos ou quase todas as iniciativas de ação ${ }^{35}$

(Ele afirma que a teoria motivacional freudiana é monística ou, no máximo, dualística.);

e) a motivação é de natureza basicamente instintiva.

Embora vá abandonar a maioria dessas idéias, criticando-as com base em pesquisa experimental, ele conserva a noção freudiana de uma certa irracionalidade do indivíduo em seu modelo teórico, como se vê abaixo:

... destruiu ${ }^{36}$ para sempre (exceto, talvez, na mente dos economistas teóricos) a idéia de que os motivos são racionais ou podem ser racionalmente inferidos das ações. (MCCLELLAND, 1975b, p. 63)

McClelland listou outros autores de uma suposta "tradição monista", ou seja, que entendem que existe uma única força motivadora, a partir da qual pode haver outras manifestações, a saber: o poder, em Adler; a necessidade de segurança, em Karen Horney, a redução da tensão ou ansiedade, em Miller e Dollard e a necessidade de autoconsistência ou integração, em Rogers, Goldstein e Lecky.

Mas ele é realmente influenciado pelas teorias de múltiplos motivos. Uma das bases importantes do seu pensamento é o trabalho de Allport, em que este autor postula que há dois níveis de motivação, o biológico e o psicogenético, mas que o segundo obtém uma autonomia funcional com relação ao primeiro.

...os impulsos biológicos, ou como ele os chamava, deficit stimuli, podiam servir para a explicação do comportamento das crianças, e podiam ainda servir como a base original para o desenvolvimento dos motivos psicogenéticos, mas uma vez formados, os motivos psicogenéticos não mais possuiriam qualquer conexão que fosse com seus antecedentes históricos.

\footnotetext{
${ }^{35}$ Do inglês striving, que significa colocar vigorosamente em ação.

${ }^{36}$ Ele estava referindo-se ao trabalho de Freud.
} 
Eles continuavam a funcionar autonomamente, com "energia" própria, sem qualquer dependência posterior aos estados biológicos ou condições. (MCCLELLAND, 1967, p. 403)

Na obra de Murray, McClelland foi buscar as bases teóricas para articular a passagem entre a influência da cultura e a vida individual. $O$ sistema de motivação daquele autor é pluralístico, e ele define motivo da seguinte forma:

Um motivo é um construto (ficção conveniente ou conceito hipotético) que representa uma força (a sua natureza físico-química é desconhecida) em uma região do cérebro, uma força que organiza percepção, apercepção, intelecção, conação e ação de forma a transformar em uma certa direção uma situação existente e insatisfatória. (MCCLELLAND, 1967, p. 406).

Murray deslocou o estudo das necessidades humanas de noções como instintos e impulsos para a noção de atitudes. Ele listou cerca de 20 necessidades em seu modelo de personalidade e desenvolveu um instrumento de avaliação destas necessidades, chamado Teste de Apercepção Temática (TAT), bastante conhecido no meio da psicologia clínica.

McClelland testou seu modelo através de diversas estratégias de pesquisa, mas focalizou inicialmente a necessidade de realização ${ }^{37}$, que ele considerava relevante. Ele realizou diversas pesquisas nas quais se avaliava a centralidade deste conceito para a sociedade norte-americana e criou uma explicação alternativa aos dados de Weber, para explicar a relação entre "o espírito do capitalismo" e as religiões reformadas.

McClelland desenvolveu um instrumento de pesquisa que permitia a avaliação dessa necessidade com base em uma adaptação do TAT de Murray. Uma vez construído e validado esse instrumento, ele passou a empregá-lo para testar seus pressupostos teóricos.

No final de seu trabalho, McClelland sintetizou a sua teoria da motivação da seguinte forma:

\footnotetext{
${ }^{37}$ Do inglês "need of achievement".
} 
a) Todos os motivos são aprendidos (Uma vez entendido um motivo como uma "forte associação afetiva, caracterizada por uma reação objetiva antecipatória e baseada na associação passada de certos sinais como o prazer ou a dor ${ }^{38}$.);

b) Os motivos são individualmente adquiridos, mas certas situações produzirão prazer ou dor com tal regularidade, através de arranjos biológicos ou culturais, que a probabilidade de alguns motivos comuns desenvolverem-se em todas as pessoas é muito alta;

c) A presença de um motivo pode ser inferida indiretamente, "baseada no conhecimento das associações passadas sinal-emergência de afeto" ou diretamente, "baseada em estados finais imaginários";

d) Um motivo persiste na vida de uma pessoa em função de: frequiência da associação sinal-prazer, generalidade da associação e facilidade com a qual pode ser extinta, estresse envolvido na associação, quando ela é formada e a idade na qual a associação afetiva é formada (quanto mais cedo, melhores as condições de generalidade e estresse);

e) Não há porquê se preocupar em apoiar os motivos exclusivamente em impulsos ${ }^{39}$ primários biológicos;

f) Os motivos podem ser adquiridos durante a vida.

\subsubsection{A origem das necessidades}

Um dos pressupostos sobre o qual repousa seu modelo teórico de motivação reside na idéia de que os motivos não são herdados, mas aprendidos. McClelland afirma

\footnotetext{
${ }^{38}$ MCCLELLAND, 1967, p. 466.

39 Tradução da palavra inglesa "drive".
} 
que a cultura e a biologia podem ser bases para os motivos considerados universais, mas não são os motivos em si. A fome é motivadora porque seus sinais biológicos (contrações do estômago e o cheiro de comida) se acham associados ao prazer da alimentação, e este prazer é reforçado várias vezes por dia ao longo da vida. O que seria, portanto, o motivo é a expectativa de prazer (ou de evitação da dor), que a pessoa associou a algum sinal no decorrer da existência.

Assim, seria necessário estudar uma pessoa para identificar que motivo se destacou em seu funcionamento psíquico, durante a vida. McClelland defende que a análise da imaginação da pessoa é um bom caminho para a identificação da presença desse motivo. Ele argumentou que este mesmo caminho foi trilhado por Freud e Murray $^{40}$ e fez um experimento, mostrando como pessoas privadas de alimentação vão, com o passar do tempo, tendo este tema mais presente em sua imaginação.

\subsubsection{A necessidade de realização e o trabalho.}

As pesquisas se focalizaram inicialmente no que se denominou necessidade de realização.

Murray houvera entendido a necessidade de realização ou atitude realizadora de forma vaga, envolvendo "superar obstáculos, exercer o poder, lutar para fazer alguma coisa difícil tão bem quanto rapidamente. É uma necessidade elementar do ego que pode ativar qualquer ação separadamente ou ser fundida com outra necessidade".

McClelland decide estudar a necessidade de realização com base em histórias criadas por sujeitos a partir de imagens que lhes são mostradas. Ele lança mão, portanto, do conceito de "realização imaginária", que é identificado com "o sucesso na

${ }^{40}$ MCCLELLAND, 1955b, p. 404 
competição com algum padrão de excelência" nas histórias inventadas. ${ }^{41}$ Em um artigo da American Psychologist, já no final de sua obra, ele define a necessidade de realização como "o desejo de fazer alguma coisa melhor ou de forma mais eficiente do que já foi feita ${ }^{42,}$.

Como se dá a satisfação da necessidade de realização? O autor entende ${ }^{43}$ que ela pode ser observada na gratificação encontrada pelo indivíduo, ao constatar o sucesso de uma dada ação iniciada por ele e que este sucesso é o próprio resultado da ação, e não o seu reconhecimento público (este estaria vinculado à necessidade de afiliação). As referências ao trabalho em si, ao processo e ao sucesso da chegada à sua finalidade são alguns de seus indicadores.

O maior problema que McClelland enfrenta com este conceito instrumentalizado, tornado central na maioria das contribuições que ele dará aos estudos sobre o trabalho, reside na instabilidade desse indicador. Ele não resiste incólume aos testes estatísticos psicométricos, especialmente aos estudos de fidedignidade, o que significa que há uma variação expressiva nas provas de teste-reteste e nas provas de duas metades que McClelland lhe aplica durante as inúmeras pesquisas feitas. Embora tente defender-se desta variabilidade, o autor norte-americano a reconhece em seus trabalhos, como se pode ver abaixo:

Mas, o problema prático (excluído o tédio da codificação do conteúdo) é a pequena fidedignidade do operante que se pensa medir. (MCCLELLAND, 1973, p. 12)

Outro problema que não passa despercebido ao leitor atencioso reside na generalização, às vezes exagerada, de seus experimentos, e uma certa displicência na análise dos indicadores estatísticos.

\footnotetext{
${ }^{41}$ MCCLELLAND, 1953, p. 110.

${ }^{42}$ MCCLELLAND, D., BURHAN, D., 1997, p. 125.

${ }^{43}$ MCCLELLAND, 1975b, p.282.
} 
Em suas pesquisas, de base primordialmente experimental, ele compara o desempenho de grupos de pessoas com alta e baixa necessidade de realização. e observou que as pessoas de alta necessidade de realização tendiam a "resolver mais problemas aritméticos por unidade de tempo", "aprender a decodificar palavras misturadas mais rapidamente" e "mostrar melhor desempenho em testes de anagramas".

Com base nestes e em outros estudos com outros motivos (como a fome), ele teoriza que: "à medida que um motivo aumenta a sua intensidade, ele inicialmente leva a um aumento de eficiência da atividade instrumental e, então, tende a um decréscimo ${ }^{44}$. É uma idéia de certo nível de "ansiedade criativa", aos moldes das teorias do estresse, seguida por uma redução do desempenho.

Esta posição não deixa de ser contrária à famosa crítica ${ }^{45}$, feita por ele, aos testes de inteligência, alegando que sua capacidade preditiva se restringia ao desempenho escolar, principalmente por duas razões: por avaliarem comportamento respondente (e não operante) e por proporem atividades muito próximas às realizadas pelos avaliadores escolares, mas muito distantes do cotidiano.

Críticas à parte, McClelland realizou inúmeros estudos comparativos internacionais e organizacionais, nos quais articulou seu conceito de necessidade de realização ao desenvolvimento econômico de países e ao desenvolvimento de organizações.

Um de seus trabalhos associa a necessidade de realização a comportamentos então considerados importantes para o desempenho do papel gerencial, a saber:

\footnotetext{
${ }^{44}$ MCCLELLAND, 1967, p. 485.

${ }^{45}$ MCCLELLAND, 1973.
} 
Quadro 4: Papel gerencial e necessidade de realização

\begin{tabular}{l|l}
\hline \multicolumn{1}{c|}{ Papel Gerencial } & \multicolumn{1}{c}{ Necessidade de Realização } \\
\hline $\begin{array}{l}\text { Aceitação moderada de riscos como função da } \\
\text { capacidade de decisão }\end{array}$ & $\begin{array}{l}\text { Pessoas com alta necessidade de realizaçâm } \\
\text { preferência por apostas de probabilidade } \\
\text { intermediária, desde que tenham a } \\
\text { possibilidade de intervir no resultado com sua } \\
\text { própria habilidade. }\end{array}$ \\
\hline Atividade Instrumental ou Vigorosa & $\begin{array}{l}\text { Pessoas com alta necessidade de realização só } \\
\text { trabalham mais quando há uma probabilidade } \\
\text { de que seus esforços interfiram nos resultados. }\end{array}$ \\
\hline Responsabilidade Individual & $\begin{array}{l}\text { "A satisfação de realização surge de ter sido } \\
\text { iniciada uma ação que foi bem sucedida e não } \\
\text { do reconhecimento público de um } \\
\text { cometimento individual." }\end{array}$ \\
\hline Conhecimento dos Resultados das Decisões & $\begin{array}{l}\text { "Por agora, podemos concluir que a pessoa de } \\
\text { alta necessidade de realização está orientada, } \\
\text { como o homem de negócios deve estar, para } \\
\text { uma realimentação tão concreta quanto a maior } \\
\text { ou menor perfeição do trabalho que está } \\
\text { realizando; e, portanto, sentir-se-á mais feliz e } \\
\text { desempenhará melhor o papel empresarial." }\end{array}$ \\
\hline Previsão de Possibilidades Futuras e Aptidões \\
da Organização & $\begin{array}{l}\text { Pessoas com alta necessidade de realização } \\
\text { "contam histórias que tratam, mais } \\
\text { freqüentemente, de um futuro remoto", } \\
\text { "pensam mais em termos de um futuro } \\
\text { perfeito" e "tendem a prever o futuro antes que } \\
\text { ele ocorra”. }\end{array}$ \\
\hline
\end{tabular}

Fonte: MCCLELLAND, 1975, p. 253-292.

Com base neste trabalho, ele deseja mostrar que há uma relação entre o desenvolvimento econômico e a necessidade de realização, em outras palavras, pessoas com mais alta necessidade de realização teriam um envolvimento maior com atividades de empreendimentos e gestão e impulsionariam mais a economia de seus referidos países. Ele chega a fazer um estudo intercultural ${ }^{46}$ no qual mostra que nos países desenvolvidos de sua amostra há mais proporção de pessoas com necessidades de realização alta entre gerentes que entre profissionais liberais, quando comparados a países subdesenvolvidos No caso em questão, apenas a Turquia, em uma amostra que se compunha também de Polônia e de profissionais do norte e do sul da Itália, obteve uma diferença significativa. Um leitor desapaixonado observa que McClelland tenta encontrar evidências que sustentem sua hipótese, não se apercebendo das frágeis

\footnotetext{
${ }^{46}$ MCCLELLAND, 1972, p. 317-324.
} 
associações e das contradições que seus dados lhe apresentam. Possivelmente as críticas o fizeram introduzir uma outra necessidade em seus estudos, denominada necessidade de poder.

\subsubsection{A necessidade de poder e o trabalho}

Estudando gerentes de empresas, McClelland conclui que as pessoas com alta necessidade de realização são geralmente "líderes de um homem só", gostam de fazer as atividades com suas próprias mãos e são pouco dependentes da opinião dos outros, sendo, portanto, mais talhados para os pequenos negócios e as vendas que para serem grandes executivos. A mera necessidade de realização "não prepara as pessoas para lidar com problemas de liderança, poder e influência social ${ }^{47}$ ". Contudo, apenas o conceito de necessidade de poder era insuficiente para distinguir o que ele denominaria de "construtor de impérios" e o "líder altruísta".

Um dos exemplos marcantes que ele apresentou em seu texto foi o de um grande empresário norte-americano, bem sucedido, que pontuou zero na escala de necessidade de realização, ou seja, ele não se motivaria pela necessidade de realização, mas obteve alta pontuação na necessidade de poder.

Uma alta pontuação em necessidade de poder, apenas, não explica a dinâmica da motivação de diretores e gerentes de grandes empresas. Para tanto foram empregados os conceitos de maturidade, inibição e necessidade de afiliação.

McClelland (1975) desenvolveu um quadro associativo entre o poder e a inibição. Ele não faz uma definição rigorosa de definição, mas o leitor depreende que se trata de inibição dos próprios impulsos e interesses em favor de outrem, seja de uma

\footnotetext{
${ }^{47}$ MCCLELLAND, 1975a.
} 
pessoa ou de uma organização, ou algo abstrato como um valor. A necessidade de poder foi definida como a "necessidade primária de se sentir forte, e secundária de agir poderosamente" ${ }^{48}$. Uma de suas dimensões é a influência que, exercida sobre os demais, se torna importante em sua avaliação.

McClelland parte da classificação do poder em quatro quadrantes, que ele denomina de estágios.

\section{Quadro 5: Estágios de poder}

\begin{tabular}{l|l}
\hline $\begin{array}{r}\text { Estágio I: A fonte do poder é interna, } \\
\text { e o objeto do poder é interno (sentir-se poderoso). }\end{array}$ & $\begin{array}{r}\text { Estágio II: A fonte do poder é interna, } \\
\text { e o objeto do poder é externo (acumular coisas, por } \\
\text { exemplo). }\end{array}$ \\
\hline $\begin{array}{l}\text { Estágio III: A fonte do poder é } \\
\text { interna, e o objeto do poder é externo (ter impacto } \\
\text { sobre os outros). }\end{array}$ & $\begin{array}{l}\text { Estágio IV: A fonte do poder é } \\
\text { externa, e o objeto do poder é externo (ser levado a } \\
\text { fazer o seu trabalho). }\end{array}$ \\
\hline
\end{tabular}
Fonte: McClelland, 1975.

Em todos os estágios, pode haver comportamentos patológicos, mas com outros conceitos suplementares, o autor desenvolve um quadro onde associa estágios de poder com maturidade e liderança, a saber:

Quadro 6: Estágios de poder, maturidade e liderança

\begin{tabular}{c|c|c}
\hline \multicolumn{2}{c|}{ Níveis de Maturidade } & Liderança Potencial \\
\hline Estágio I & Baixa motivação para o poder & $\begin{array}{c}\text { Não assertivo o suficiente para } \\
\text { fornecer boa liderança, exceto em } \\
\text { certas situações. }\end{array}$ \\
\hline Estágio III a & $\begin{array}{c}\text { Alta motivação para o poder e } \\
\text { baixa inibição }\end{array}$ & $\begin{array}{c}\text { O “conquistador", padrão de } \\
\text { dominância pessoal, particularmente } \\
\text { se a necessidade de afiliação é } \\
\text { também baixa. }\end{array}$ \\
\hline Estágio IIIb & $\begin{array}{c}\text { Alta motivação para o poder e alta } \\
\text { inibição }\end{array}$ & $\begin{array}{c}\text { Padrão de motivação imperial, } \\
\text { particularmente se a necessidade de } \\
\text { afiliação é também baixa. Rude com } \\
\text { tendências de organização eficientes. }\end{array}$ \\
\hline Estágio IV & $\begin{array}{c}\text { Alta motivação para o poder, alta } \\
\text { inibição e altos escores do estágio } \\
\text { IV }\end{array}$ & $\begin{array}{c}\text { Liderança altruísta, tendências de } \\
\text { organização eficientes. }\end{array}$ \\
\hline
\end{tabular}

Fonte: MCCLELLAND, 1975, p. 264.

${ }^{48}$ MCCLELLAND, 1975, p. 77. 
Com base nestas associações, distingue-se o poder pessoal $^{49}$ do poder socializado $^{50}$. O primeiro é voltado à pessoa, o segundo está associado à inibição e leva em consideração as necessidades institucionais/organizacionais. Portanto, com a noção de poder socializado e a análise das necessidades de afiliação e de realização, o autor propôs a construção de alguns estilos gerenciais, dos quais se destaca o "gerente institucional".

As principais características do gerente institucional ${ }^{51}$ são a orientação para a organização, o fato de declararem gostar de trabalhar, a disposição de sacrifício de alguns interesses pessoais pelo bem da organização a que servem e a apresentação de uma noção aguda de justiça.

\subsubsection{Críticas e conclusões.}

Uma contribuição do trabalho de McClelland para a nossa pesquisa reside no modelo de personalidade que ele desenvolveu, especialmente na articulação que faz entre a cultura das instituições e das organizações e o indivíduo. Ela reforça o posicionamento de outros autores que estudam cultura como "regras do jogo", e não como uma forma ou realidade a ser introjetada pelos seus participantes.

Outro ponto importante reside na defesa que o autor faz de uma dinâmica da motivação de base psicológica, mas interligada aos substratos orgânicos e culturais. Nem os homens funcionam como organismos biológicos falantes, nem como células do tecido social, determinadas pelas macroestruturas sociopolíticoeconômicas, mas como indivíduos dotados de uma corporalidade e participantes da cultura.

\footnotetext{
${ }^{49}$ Do inglês p Power.

${ }^{50}$ Do inglês s Power.

${ }^{51}$ MCCLELLAND \& BURNHAN, 1997, p. 135.
} 
A proposta de McClelland solicita, portanto, que o pesquisador da motivação no trabalho (profissional ou voluntário) esteja atento às dimensões das necessidades psicológicas de afiliação, de realização e de poder. Elas podem ter um papel explicativo particularmente importante para um fenômeno como o trabalho voluntário, em que os interesses financeiros não fazem parte direta da relação entre trabalhador e organização.

A pesquisa desse autor não explicita se ou como os outros motivos propostos por Murray se relacionariam com o mundo do trabalho. Outro problema metodológico diz respeito à sua escolha em estudar as fantasias, a partir de estímulos temáticos, que, de alguma forma, as eliciam, mas os seus comentários metodológicos apontam para a possibilidade da investigação direta, com base nos relatos que o indivíduo faça sobre a própria experiência. Este caminho passa a ser desenvolvido no presente trabalho. Outro ponto obscuro no trabalho de McClelland diz respeito a uma proposta de categorias e de metodologia para o estudo dos traços psicológicos. Esse aspecto não foi devidamente explorado pelo autor e muito menos avaliado face às peculiaridades do mundo do trabalho.

A opção que se faz, portanto, nesta pesquisa, é a de explorar a motivação a partir dos relatos de história de vida feitos pelos indivíduos pesquisados, dando especial atenção às suas fontes de satisfação e insatisfação, o que permite identificar caso a caso a associação da dinâmica da motivação e dos schemata construídos no nível do indivíduo.

Outro ponto importante a ser considerado, com base na teoria de McClelland e na teoria de Maslow, diz respeito aos mecanismos de gratificação, ou seja, é importante investigar se as fontes de satisfação, uma vez considerada a influência dos 
schemata individuais, agem como redutoras ou como eliciadoras de novos comportamentos a elas associados.

4.3 Joseph Nuttin: A motivação vista por um interacionista

Nuttin nasceu em 1909, estudou teologia em Brugge e Filosofia na Universidade Católica de Louvain. Orientou mais de 180 teses de mestrado e 50 de doutorado. Construiu o Instituto de Psicologia de Louvain e foi co-fundador da Sociedade de Psicologia da Bélgica. Publicou mais de 15 livros em três idiomas, que foram posteriormente traduzidos para mais de sete idiomas diferentes. Doou, após a sua morte, fundos para a pesquisa básica na Faculdade de Psicologia e Pedagogia da Universidade Católica de Louvain.

Ele desenvolveu sua produção em torno da chamada pesquisa básica em Psicologia, pesquisando personalidade, aprendizagem e motivação. Seu trabalho teve mais impacto na educação, como é o caso da chamada "pedagogia de projetos" e junto a autores de marketing. Sua principal diferenciação dos autores até então estudados consiste na sua visão de homem como sujeito e capaz de dar significados aos objetos, o que possibilitou que ele desenvolvesse uma teoria de motivação mais complexa, posto que atrelada à necessidade de compreensão do sentido dado pela pessoa.

\subsubsection{Uma visão de homem singular}

A trajetória de Nuttin por diferentes escolas de pensamento psicológico deixou, como marca em seu trabalho, a tentativa de construir uma visão complexa de homem. A primeira singularidade de sua teoria é a ampliação do conceito de 
comportamento, que tem por conseqüência uma visão de homem como uma unidade funcional, integrada, com dois pólos: o indivíduo e o ambiente.

O comportamento, para este autor, é definido como uma função de relação, e não apenas os aspectos observáveis da ação. Esta noção ampliada de comportamento permite que se inclua o chamado "mundo do segundo nível", que é o mundo conhecido das representações simbólicas. Ela também permite que a análise dos fenômenos humanos não seja reduzida à influência de mecanismos biológicos, ao encadeamento de instintos ou ao de motivos psicológicos inatos. Outra contribuição distinta da teoria de Nuttin é a possibilidade de articulação que ela dá ao pesquisador entre o indivíduo e a cultura, sem tornar o primeiro um subproduto da segunda.

Como bom conhecedor das teorias behavioristas e cognitivistas, Nuttin (1980) fundamenta seus princípios apontando a fragilidade dos modelos concorrentes. Foge ao escopo deste trabalho a reprodução dos argumentos desse autor, posto que seu foco é a teoria de motivação.

... o fenômeno fundamental da motivação se manifesta no funcionamento comportamental e consiste em que o organismo se orienta ativamente e de forma preferencial em direção a certas formas de interação, a tal ponto que certas categorias de relação com certos tipos de objetos são exigidas ou indispensáveis ao funcionamento. (NUTTIN, 1980, p. 13)

Esta contribuição é importante, uma vez que ele teoriza, incluindo as representações individuais na explicação dos processos de motivação. Ele dá, portanto, uma alternativa metodológica ainda mais sofisticada e melhor fundamentada que a de McClelland para a análise fenomenológica da motivação. 
4.3.2 As noções de motivação revisitadas

A teoria de Nuttin é integradora, no sentido em que ela não apenas nega as contribuições das escolas anteriores, mas as incorpora, abandonando aspectos e limitações que não resistem à crítica. Muchielli refere-se a essa teoria da seguinte forma:

\begin{abstract}
Esta interessante concepção concilia finalmente o inatismo (existência da necessidade de interações em diferentes níveis), o empirismo (existência de aprendizagens) e o situacionismo (a estrutura do mundo orienta as formas concretas de satisfação). Tal concepção se apóia sobre uma visão nova das pesquisas das motivações e além disso, de toda a Psicologia Social. (MUCHIELLI, 1981, p. 25)
\end{abstract}

Ele classifica as teorias sobre o processo de motivação em cinco grandes categorias: as teorias que concebem a motivação como estímulo e descarga de energia; as que a concebem como associações e conexões, as que a concebem como um fator fisiológico; as que a definem como um fator de energização do organismo e as teorias de homeostase, que entendem a motivação como um mecanismo de adaptação e estabilidade interna.

A motivação vista como descarga de energia seria um modelo próprio da psicanálise freudiana, da etologia e de algumas teorias de aprendizagem. Este modelo propõe que a motivação derivaria de um estado desagradável do organismo, do qual o sujeito deve se desfazer.

A noção associacionista, própria da escola comportamentalista, entende a motivação como um estímulo que leva a uma resposta.

A noção calcada na fisiologia entende que a motivação é fruto de necessidades e pulsões de base fisiológica, tais como a fome, a sede, a sexualidade, o sono e a necessidade de oxigênio. 
A noção de motivação como um fator de energização do organismo se baseia na idéia de que o estado natural do organismo é o repouso, e que a motivação o retira deste estado, por meio de um estímulo exterior ou interior. Ele, entretanto, apresenta as idéias de Hebb que mostra que uma célula nervosa não necessita de uma atividade para ser ativa: a atividade é sua condição natural, o que coloca em questão o fundamento central desta posição teórica, deslocando-a para as escolhas que o sujeito faz em uma dada situação.

A noção homeostática pressupõe que haja um nível de funcionamento ótimo do organismo, o equilíbrio homeostático, que uma vez rompido por uma razão qualquer (a falta ou necessidade de água para o organismo) leva o sujeito a buscar uma forma de restauração desse equilíbrio. Esta é uma das principais noções que Nuttin discutiu em seu trabalho e que ele considera insuficiente para explicar a dinâmica motivacional dos indivíduos. Um dos contra-exemplos que ele dá para o modelo homeostático é a situação da criança entretida no jogo, que, mesmo sentindo fome, desconsidera seu impulso pelo prazer de brincar. Outra situação é a escolha de alimentos que o sujeito faz ao sentir fome, podendo rejeitar alimentos cujo valor nutricional satisfaria sua necessidade biológica.

Da crítica e posterior desenvolvimento dessas noções, Nuttin desenvolveu um modelo relacional de motivação que será apresentado a seguir.

\subsubsection{A teoria de motivação de Nuttin}

Uma vez constatada a visão relacional do sujeito e a ampliação da noção de comportamento, questiona-se o que é motivação na teoria do autor belga. 
Uma redefinição importante é feita com o conceito de necessidade. Ela passa a ser "relações exigidas ${ }^{52}$ entre o indivíduo e o mundo" ou "esquema de relações exigidos". Não pode ser reduzida à idéia de carência, que acolhe em seu bojo as "atividades orientadas para o crescimento, o autodesenvolvimento e a comunicação". (NUTTIN, 1980, p. 92) Ela possui uma dupla conexão, com o mundo "interno" do sujeito e com o mundo "externo" a ele. Nuttin não nega que o indivíduo necessite alimentar-se, mas entende que a motivação não se reduz ao ato de eliminar a sensação de fome; envolve também o processo de obtenção do alimento, a escolha do tipo de alimento desejado, os comportamentos da refeição, etc. Ele, como Maslow, entende que o "ser humano tem necessidade de explicação e progresso, da mesma forma que tem necessidade de oxigênio" (NUTTIN, 1980, p. 269).

Esses e outros exemplos fazem com que Nuttin defina as motivações mais em termos de "objetos comportamentais" que em termos de "estímulos, de energia ou estados intra-orgânicos ou ainda de reações motoras" (NUTTIN, 1980, p. 92). Ele põe de ponta-cabeça a idéia de que uma necessidade faz com que o indivíduo busque um objeto que a satisfaça, formulando que "a natureza mesma do objeto (por exemplo, a nutrição, a consideração social ou a afeição) que define a natureza da necessidade, isto é, da relação exigida", como se pode ver abaixo:

A motivação humana não se concebe em termos de descarga de energia ou de evitação de estímulos, mas em termos de projetos e de estruturas meiofim; ela supõe uma concepção do comportamento que se estende para além dos elementos estímulo-resposta. (NUTTIN, 1980, p. 37)

Haveria três fases essenciais no processo comportamental. Uma primeira em que a situação atual seria percebida ou construída pelo sujeito, uma segunda em que

\footnotetext{
${ }^{52}$ Do francês relations requises.
} 
esse sujeito define uma situação-objetivo a ser atingida e uma terceira em que ele define uma ação a ser executada para mudar a situação atual na direção desejada.

A primeira fase envolve dois níveis: o das coisas reais percebidas e o das representações simbólicas.

O homem se comporta em um mundo de falas, de sinais e de símbolos, mas também em um contexto de objetos físicos. O mundo social, principalmente, se constrói em função da comunicação de conteúdos cognitivos e afetivos. (NUTTIN, 1980, p. 54)

A segunda fase consiste na construção de um projeto de ação em que as possibilidades do mundo externo são avaliadas pelo sujeito que considera as restrições e valorizações de seu mundo interior para estabelecer objetivos-meta.

A terceira fase, a fase da ação, é fundamental para a compreensão do papel dos objetivos, no processo de motivação. Nuttin entende que a ação pode ser codeterminada por fatores físicos e fisiológicos, mas ela é "regulada e modulada, a cada momento de sua execução, por um projeto cognitivo, que se constitui em padrões ou objetivos. A ação não é um processo automático ou condicionado, embora possa sofrer influências dos "resíduos de experiências e ações anteriores".

O indivíduo é ao mesmo tempo o agente do processo e o objeto da ação. Neste caso, o indivíduo-objeto faz parte do mundo ou ambiente percebido sobre o qual exerce a ação de indivíduo-sujeito.

A motivação não surge de tempos em tempos, para desencadear uma ação isolada. Ela é uma orientação dinâmica contínua que regula o funcionamento, igualmente contínuo, do indivíduo, em interação com o seu meio. Esta regulação envolve os aspectos direcionais e energéticos do comportamento. De outro lado, a todo o momento, a motivação se apresenta como uma configuração concreta de tais orientações dinâmicas permanentes (ativas ou latentes). A estrutura desta configuração 
muda em função de numerosos fatores internos e externos, em função também da experiência passada e da percepção atual. Em outras palavras, a motivação humana é um processo cognitivo e não um processo de descarga de energia ou de retorno a um estado de equilíbrio homeostático.

A origem da motivação não é interna ou externa, mas recíproca. $\mathrm{O}$ objeto que incita o sujeito tem por correspondente uma motivação interna latente, que visa a um objeto desejado, circunscrito por canalização ou projeto.

A motivação é sempre uma questão de relação entre um sujeito que deseja (eventualmente de forma latente) e um objeto que ocasiona ou desperta o interesse latente. (NUTTIN, 1980, p. 175)

A configuração motivacional é estável em alguns sujeitos (perseveração de objetivos); em outros, a maneira de agir consiste na obediência ao impulso do momento e ao apelo da situação que se apresenta.

A motivação pode ser vista como uma função dinâmica geral, que envolve a ativação e direção do comportamento, ou como uma constelação motivacional concreta, que regularia o comportamento em determinado momento.

Nuttin delimita os seguintes papéis para a motivação: regulação, direção, coordenação e unidade de significação para tal ou qual categoria de objetos que compõem os segmentos.

Ele adota a proposta desenvolvida por McClelland de desatar a motivação dos vínculos fisiológicos para reatá-la aos vínculos comportamentais.

Além da formulação dos projetos e estabelecimento de objetivos, há um mecanismo mais automático de canalização das energias, fruto da aprendizagem. A formação de projetos e a canalização se interpenetram, à medida que as respostas 
obtidas em uma experiência do sujeito constituem-se em uma espécie de repertório que o indivíduo pode acessar na construção dos novos projetos que se coloca.

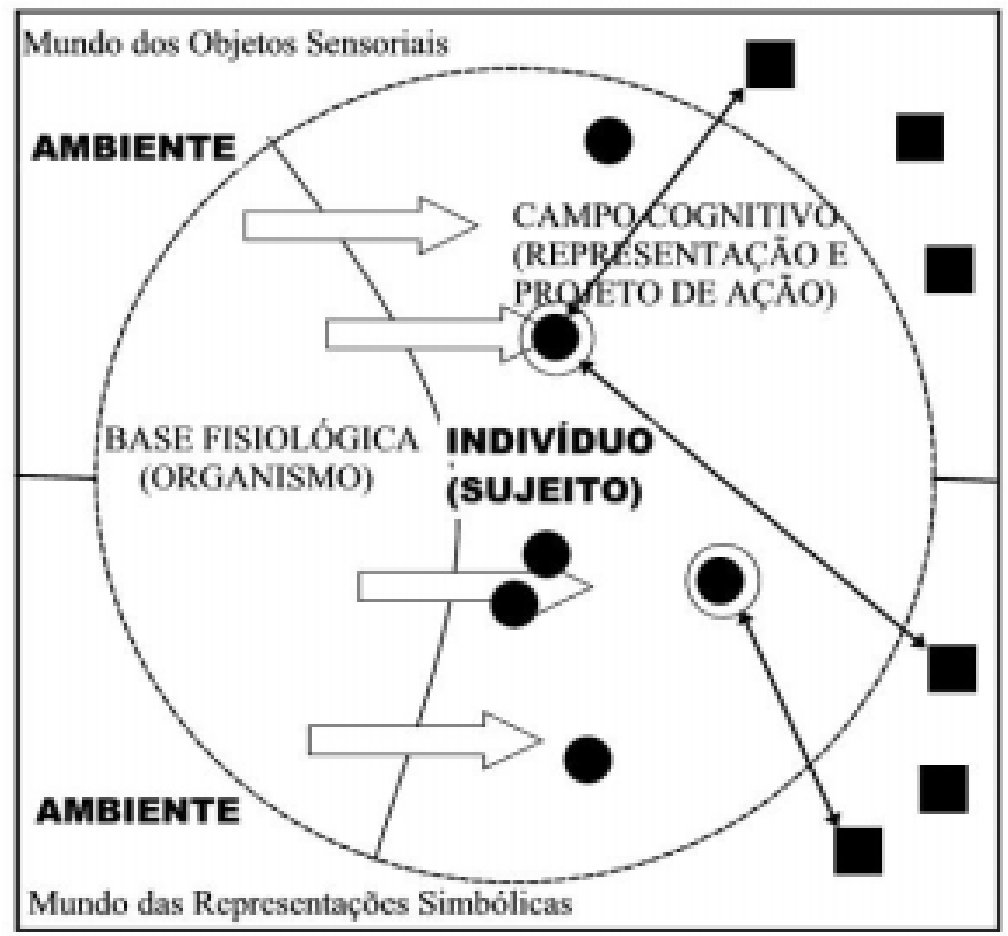

Figura 8: Proposta de representação do modelo de Nuttin de motivação

\section{LEGENDA}

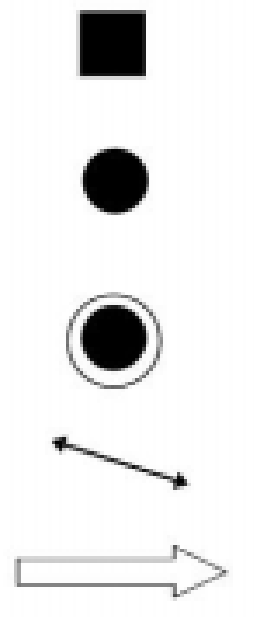

OBJETO DO AMBIENTE

(SENSORIAL OU SIMBÓLICO)

REPRESENTAÇÃO DO

OBJETO PASSIVEL

DE ESCOLHA

OBJETO ESCOLHIDO

(MOTIVO)

RELAÇÃO EXIGIDA

IMPULSO

(NECESSIDADE DE

BASE ORGÂNICA) 


\subsubsection{Necessidades fundamentais}

Nuttin desconfia dos modelos universais e lança mão das descobertas da antropologia social que mostram não haver universalidade nas maneiras de se valorizar, de procurar a consideração e o contato social nos diferentes grupos humanos. Por conseqüência, ele não deseja fazer uma lista de necessidades fundamentais ou tendências, aos moldes de Murray, mas tem clareza da importância teórica da necessidade da existência de algum tipo de quadro analítico.

O que se constata é que Nuttin empregou o método fenomenológico para buscar as essências do fenômeno da motivação nas pessoas. Ele orienta seu quadro conceitual na busca de significações comuns de condutas, constituintes de funções comuns. Esse projeto é audacioso, na medida em que ele o estende do mundo íntimo do sujeito ao seu entorno ambiental. "A questão primordial é saber quais são estas coisas que obteremos a qualquer preço ${ }^{53}$,.

Nuttin, para responder a essa questão, afirma que o ser humano possui três graus de atividade no funcionamento: o funcionamento sensorial e reativo, o funcionamento ativo e seletivo e a tendência a produzir efeitos.

A necessidade original do ser humano, portanto, é a necessidade de entrar em contato com o ambiente, ou seja, "necessidade de estimulação e de interação". Na infância o sujeito vai construindo modalidades preferenciais que podem ser alteradas futuramente, mas que permitem a construção de modalidades de canalização preferenciais.

Foge ao nosso objetivo neste trabalho discutir uma psicologia do desenvolvimento em Nuttin, por isso, uma vez posta a necessidade original e construída

\footnotetext{
${ }^{53}$ NUTTIN, 1980, p. 124.
} 
a imagem de si mesmo e do mundo, o autor passa a distinguir duas fontes de objetos que irão exigir esquemas de relação: as necessidades voltadas para o sujeito e as necessidades voltadas para o objeto (que neste ponto de sua obra ele define como a pessoa do outro, uma situação, ação ou evento, ou seja, o ambiente “externo”).

Com relação ao movimento em direção ao sujeito, o autor desconfia da artificialidade em se dividirem necessidades como a segurança, a manutenção de si mesmo, a auto-afirmação, a necessidade de entrar em competição, como Murray, por exemplo, o fez. Ele entende que uma orientação geral subjacente a todas estas necessidades, que é a conservação e o desenvolvimento ótimo da personalidade e que essas supostas necessidades não seriam mais que formas de expressão dessa tendência geral. Ao lado desta tendência, o sujeito também necessita manter uma certa consistência interna, ou seja, uma identidade autônoma, podendo até deformar certos dados perceptivos de si mesmo para manter esta concepção.

Quanto ao movimento em direção ao objeto, ele destaca, com base nos estudos evolutivos, tanto uma tensão entre a tendência à identificação e imitação como o desejo de autonomia das pessoas.

O contato com outras pessoas não é concebido como uma derivação da satisfação de necessidades fisiológicas, mas como uma via de realização do próprio desenvolvimento. $\mathrm{O}$ autor belga distingue o funcionamento fisiológico (que é a base das relações exigidas com a biosfera) do funcionamento psicológico que envolve o sujeito, em interação com as situações significativas do mundo.

Há três grandes formas de funcionamento do sujeito com o objeto: o contato cognitivo, o contato interpessoal (interação social) e a manipulação das coisas (manipulação física de objetos). 
Por necessidade de contato cognitivo, Nuttin entende ser a necessidade de informação, a necessidade de o sujeito compreender, de explicar e de explorar determinadas situações com as quais ele se acha confrontado. Posta esta necessidade, que Nuttin entende ser uma tendência cognitiva geral, resta explicar por que certos objetos despertam o interesse do sujeito enquanto outros não, o que só é passível de compreensão com o emprego de uma mediação cognitiva do sujeito.

O contato interpessoal possui diversas modalidades como a necessidade sexual, os desejos de afeição, de apreciação e de ajuda ou de cooperação. Esta última modalidade de contato social é explicada na citação abaixo:

O contato social se manifesta no fato de que, espontaneamente, muitos sujeitos possuem desejo e sentem temores pelos outros. Seguros destas motivações concernentes às pessoas concretas, os outros são mais humanitários e se relacionam, por exemplo, às condições de vida de grandes grupos de pessoas (o terceiro mundo, a classe trabalhadora, a humanidade em geral, etc.) $\mathrm{Na}$ análise dos resultados de nossas pesquisas consideramos as diferentes categorias de pessoas visadas por este gênero de motivação. (NUTTIN, 1980, p. 15)

Há também as modalidades chamadas negativas, de contato social, como o sujeito que quer ser deixado sossegado, ou deseja agredir. É importante reprisar que Nuttin não entende essas necessidades como inatas ou hereditárias, mas como frutos da aprendizagem do sujeito. A partir da história relações agradáveis ou desagradáveis o sujeito aprende a evitar ou buscar um relacionamento com uma determinada pessoa. Embora o sujeito possa ter vias preferenciais (canalizações) de comportamento frente a certos objetos, a reciprocidade dos fenômenos de motivação não pode ser esquecida na análise do contato social.

Em síntese, o autor distingue três níveis de interação entre o indivíduo e o ambiente: a biosfera, o mundo psicossocial e o mundo ideal, que se acham articulados à motivação humana. 


\subsubsection{A questão do método.}

Postas as características da motivação, pergunta-se como Nuttin a estudaria. Ele defende que deve ser realizado o estudo da significação como um caminho para a compreensão dos fenômenos comportamentais motivados.

Ele não acredita em estudos com base em privação e escolhas preferenciais porque esses estudos pressupõem o conhecimento prévio da necessidade em ação. A multiplicidade de objetos e objetivos, da qual é passível o ser humano, demanda que se discuta como problema preliminar responder à seguinte pergunta: quais são as categorias de objetos e relações que motivam o ser humano e sem as quais ele funcionaria de maneira deficiente? Qual é o efeito (positivo ou negativo) de certas relações?

Muchielli (1980) entende que Nuttin elege como objeto de análise as “formas específicas de interações indivíduo-mundo, os cenários reparáveis e repetitivos das permutas dos homens com o seu ambiente", em lugar de se deter na análise das necessidades, ou das estruturas de determinação ${ }^{54,}$.

Outra questão metodológica diz respeito à necessidade de se depreender direções ou significações comuns em uma multiplicidade de comportamentos concretos, aparentemente diferentes. O pesquisador não se deve deixar "encantar" pela aparente facilidade com que o sujeito enuncia as razões de suas ações. Neste ponto, Nuttin pesquisa como se fosse um fenomenologista, ou seja, orienta o pesquisador a compreender o sentido das palavras e ações do sujeito e a buscar a essência, que permanece além de todas as aparências. Assim, continua válido o exemplo dado anteriormente, de que a jovem mulher que deseja ter uma grande família e trabalhar e a

\footnotetext{
${ }^{54}$ Do francês: contraintes.
} 
mulher que deseja ser bem sucedida em seu trabalho podem ser igualmente motivadas pela necessidade de aceitação por pessoas consideradas importantes por elas.

Nuttin defende a incerteza explicativa da escolha dos objetos pelo sujeito. “... por quê é a afeição, por exemplo, e a consideração social, mais que a rejeição, que favorecem o bem-estar funcional, no nível psicológico - é uma questão que desafia toda explicação. Pode-se, quando muito, "compreender" a característica exigida de um objeto em uma compreensão mais global do dinamismo humano..." (NUTTIN, 1980, p. 92). Ele aceita que para um nível geral pode-se postular uma teoria explicativa, mas, com relação ao indivíduo, só se pode fazer uma análise compreensiva.

Os três autores fizeram uma leitura da dinâmica da motivação humana, respeitadas as suas diferenças teóricas, metodológicas e epistemológicas. Desenvolveram modelos complexos que se atêm a aspectos distintos da realidade subjetiva. No próximo capítulo, esboçar-se-á um modelo de análise que permita o estudo da motivação para o trabalho voluntário (e talvez para o trabalho humano de forma geral), desenvolvido a partir de uma certa visão de homem, mas considerando as contribuições das teorias revisadas. 


\section{PROPOSTA DE UM MODELO TEÓRICO PARA ESTUDO DA MOTIVAÇÃO DE VOLUNTÁRIOS E DA CULTURA DE ORGANIZAÇÕES DE TERCEIRO SETOR.}

\footnotetext{
- Deus há de lhe dar o pago, Seu Cassiano Gomes! Eu sim que não posso, por causa que não tenho préstimo nenhum... (...)

Então Cassiano, por sua vez muito bem comovido, puxou-o para si, num abraço, dizendo:

- Maior paga do que essa não tem, meu compadre Vinte-e-Um... João Guimarães Rosa
}

Uma vez aceito que as organizações de Terceiro Setor possuem algumas singularidades que as distinguem das empresas e dos órgãos de Estado, é necessário pensar no desenvolvimento de uma teoria administrativa que entenda estas peculiaridades como próprias, e não como desvios a priori dos processos de gestão. Esta tese se propõe a abordar dois pontos importantes para a gestão: a cultura organizacional e a motivação do trabalho voluntário.

No próximo item discutir-se-á a possibilidade do desenvolvimento de um modelo teórico de motivação, a partir das contribuições dos que foram estudados. Este modelo privilegia a análise da motivação do homem na realidade laboral.

5.1 Em busca da construção de um modelo teórico para o estudo da motivação

Das três teorias, a de Nuttin está mais bem desenvolvida. Ele partiu de uma visão de homem que considera a subjetividade sem cair na tentação do relativismo absoluto, posto que aceitou a existência de uma psicodinâmica geral do homem, ao mesmo tempo em que resistiu ao enquadramento rigoroso deste em modelos mecânicos e deterministas, assim como Maslow. 
Segue abaixo uma síntese dos princípios que resultaram da análise críticocomparativa dos três modelos:

5.1.1 Quanto ao conceito de motivação.

Há necessidades fisiológicas e impulsos que influenciam a ação humana, mas são geralmente mediados pela cognição ${ }^{55}$ e, possivelmente, associados a outros fenômenos psicológicos, como os fenômenos inconscientes, que se encontram essencialmente associados à dinâmica dos afetos. Neste estudo, acatar-se-á a crítica e o abandono da noção de instinto feita pelos autores revistos, que demandaria a aceitação de padrões automáticos de comportamento, herdados e desencadeados por fatores do ambiente.

Adotar-se-á a distinção feita por Nuttin e McClelland entre necessidades e motivos, segundo a qual, as necessidades atuam como impulsos de base fisiológica e desencadeiam uma multiplicidade potencial de ações. Os motivos são fenômenos psicossociais entendidos como relações requeridas entre o ambiente e o sujeito; podem ser interpretados como "projetos singulares de ação" e englobam processos de escolha de metas, objetos e processos de ação.

Não há como se aceitar o conceito de necessidades psicológicas, senão como metáfora. Uma vez aceito este conceito, fica difícil a sua distinção entre duas classes de motivos psicológicos (de auto-estima e de realização, por exemplo) por outra via que não a do operacionalismo, que nos leva a problemas ontológicos, como mostrou Nuttin na sua crítica à classificação de Maslow e à de Murray. Prevalece, portanto, o argumento de Nuttin, que prefere definir motivos em termos de relações exigidas entre o

\footnotetext{
${ }^{55}$ Segundo Nuttin.
} 
indivíduo e o ambiente e associá-los à escolha de metas e objetos pelo sujeito. Para referir-se a alguns dos fenômenos de ordem psicológica, adotar-se-á, então, o conceito de tendências, empregado aqui como predisposições gerais do psiquismo humano.

Não se confunde motivação com "razões alegadas para a ação" nem como "a causa das ações". Uma razão alegada pode ser uma resposta socialmente bem aceita, uma repetição de um preceito do grupo ou da cultura, mas que não diga respeito ao quadro pessoal de valores ou ao processo de escolha de metas e de objetos feitos pelo sujeito. Quanto à idéia de causa, ela fica prejudicada ante a complexidade do processo de construção dos motivos e à existência de mecanismos de coerção da ação humana, que é tratado a seguir.

5.1.2 Sobredeterminação e complexidade dos motivos

Um motivo pode ser influenciado por necessidades fisiológicas e por elementos da cultura que são mediados por tendências psicológicas e schematas.

Os mecanismos de controle sócio-organizacional podem frustrar a escolha de objetos-meta e impor ações ao sujeito, participando também da dinâmica da motivação.

Não só elementos da cultura das sociedades e da organização, mas também os da fisiologia influenciam, mas não determinam, os valores individuais construídos pelos sujeitos.

Embora as experiências passadas sejam fatores influentes na construção e reconstrução subjetiva dos motivos, não se pode afirmar que os motivos são fruto de experiências de prazer e de punição, como pensa McClelland, porque se admite, nesta tese, a capacidade mediadora da cognição. 


\subsubsection{Classificação de tendências}

Os motivos podem se modificar na trajetória da vida, respeitadas as tendências gerais descritas por Nuttin, que parecem ser universais, mas que não são suficientes para o entendimento do significado das ações empreendidas pelos sujeitos, nem para a categorização dos motivos em curso.

Escolheu-se a palavra tendência para designar uma espécie de pré-motivo, algo que impulsiona ou influencia o ser humano a construir um motivo. Este termo é menos "biológico" que o de necessidade (que traz em seu sentido geral um certo imperativo a ser satisfeito), mas menos cognitivo que a motivação de Nuttin, posto que não traz em seu sentido a noção de projeto de ação. O termo tendência não traz em si nenhuma associação a uma dinâmica, e não se refere ao conceito de tendência desenvolvido por Gordon Allport. Ela não se confunde com a noção de necessidades fisiológicas, também empregada neste modelo teórico.

O melhor quadro de tendências é o de Nuttin, que propõe como tendências ${ }^{56}$ gerais do ser humano: a de buscar a estimulação; a de conservar e desenvolver a personalidade, preservando a consistência interna (manter uma identidade autônoma); a tendência a estabelecer contato cognitivo (informar-se, entender o mundo "exterior" e “interior”); a tendência a estabelecer contato interpessoal e a manipular objetos físicos. A elas se adicionarão a tendência à realização e as tendências à afiliação e ao poder, extraídas da teoria de McClelland. As duas últimas serão aspectos da tendência a estabelecer contato interpessoal.

O papel dessas tendências é orientar o pesquisador para que ele não reduza seu foco de análise. Elas não servem, portanto, como listas de motivos, nem devem ser

\footnotetext{
${ }^{56}$ Nuttin não emprega esta palavra, mas usa o conceito necessidade, que foi restrito neste trabalho.
} 
consideradas como uma relação que abranja todas as tendências possíveis. Elas asseguram a percepção do mundo "interno" e do ambiente "externo" no estudo de motivação.

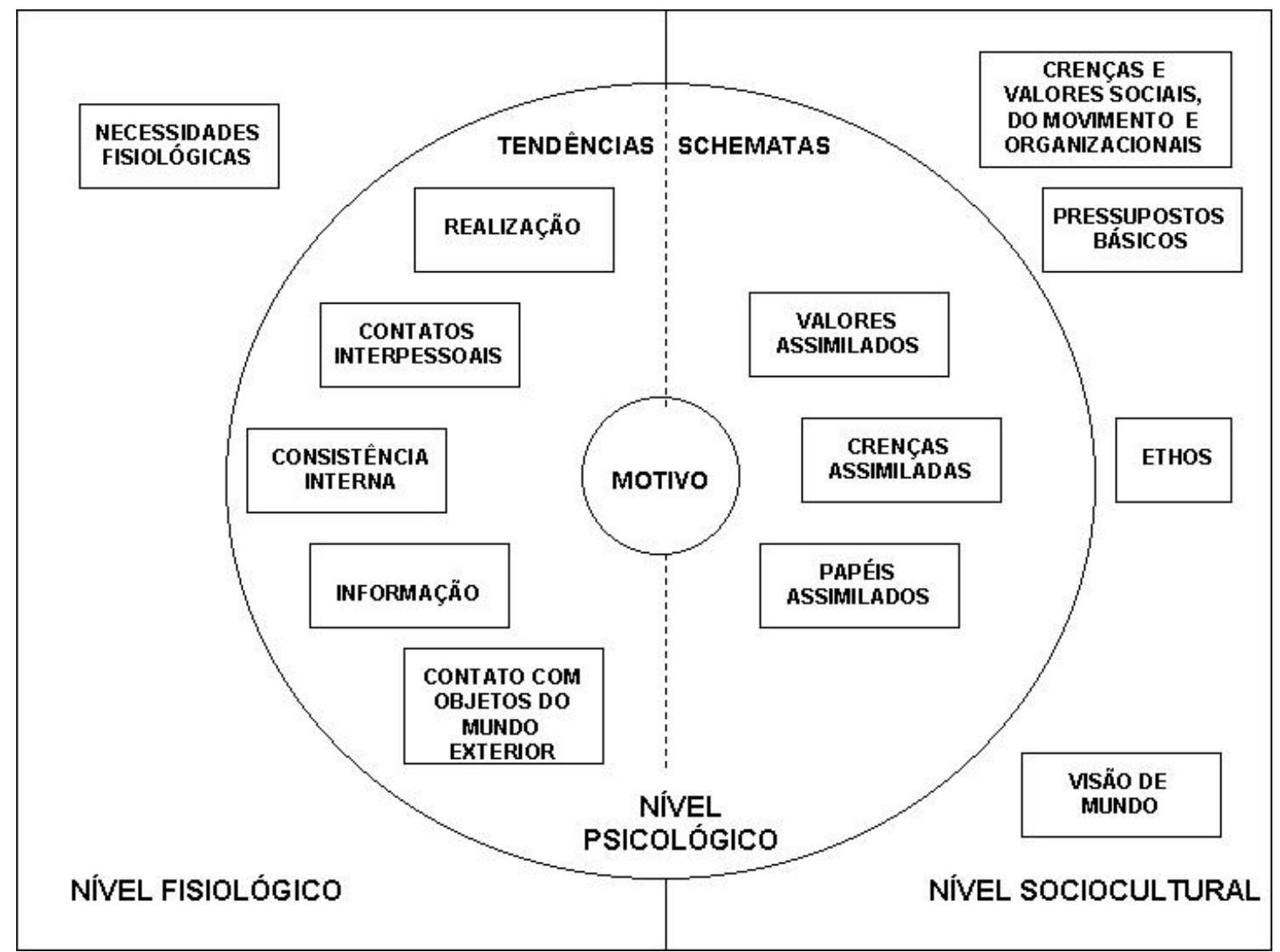

Figura 9: Níveis de construção dos motivos

\subsubsection{Dinâmica da motivação}

Os três autores estudados criticam as diferentes metáforas que foram utilizadas para explicar a dinâmica da motivação. Uma vez aceito que a motivação não se reduz a uma delas, procurou-se esboçar um modelo teórico que as comportasse em seus respectivos domínios.

A lógica da homeostase e da redução de tensões é própria das relações entre as necessidades fisiológicas e os motivos. Projetos de ação são criados e desenvolvidos 
pelos sujeitos para atender às necessidades fisiológicas e deixar o organismo em uma condição confortável de funcionamento e em um nível tolerável de tensão oriunda da sensopercepção do próprio corpo, em contato com o ambiente físico-químico.

As tendências, que seriam construtos ou forças de ordem psicológica, funcionariam como energizadoras de um determinado projeto de ação. O sujeito que relata inúmeras experiências de gratificação, associadas a contatos interpessoais de cunho afiliativo e afetivo, por exemplo, teria nesta tendência uma fonte de energização de seus projetos de ação relacionados a ela, diferentemente do sujeito que relata espontaneamente inúmeras experiências de controle sobre o comportamento de terceiros. Com base na literatura revista, é difícil tratar de uma gênese e desenvolvimento das tendências ou defender uma hierarquia de preponderância dentre elas, ou sequer assegurar que este mecanismo seria exclusivo.

Entende-se que a metáfora da energia psíquica, ou energização do projeto de ação, não cede às críticas de Hebb, que defende que o estado natural do organismo é a atividade $^{57}$, uma vez que se refere ao diferencial de mobilização do sujeito, seja na escolha do objeto-meta, seja na realização da ação motivada.

Os schemata individuais trazem em seu bojo os valores morais e a visão de mundo singular, construída pelo sujeito a partir da sua interação com a cultura. Denominou-se assimilação ativa a relação entre os schemata e a cultura, por se entender que o sujeito interage com sua cultura e escolhe idéias de diferentes sociedades, grupos sociais, instituições e organizações, podendo igualmente dar novo significado a elas ou dar diferente intensidade valorativa a determinadas crenças da cultura de uma organização de que seja membro. Como o sujeito reconstrói interiormente a cultura da

\footnotetext{
${ }^{57}$ Ao contrário do que afirma Nuttin.
} 
sociedade onde vive, especialmente se vive em sociedades pluralistas, entendeu-se que o termo "assimilação" utilizado por McClelland não traria em seu contexto a dimensão de subjetividade, necessária ao entendimento das relações entre schemata e cultura.

Se se focaliza a relação entre os schemata e os motivos, vê-se que os autores revistos não propõem uma dinâmica. Eles são uma instância que dá conformação aos projetos de ação construídos pelo sujeito, permitem a construção do significado destes e influenciam a escolha das metas que o sujeito se propõe. Eles atuam na auto-imagem do sujeito que os confronta com a sua experiência interior. Denomina-se identificação a esta dinâmica, por haver confronto com o conceito de si mesmo e por possibilitar a construção de motivos segundo a referência interna e a externa.

A identificação é entendida aqui como uma operação psíquica em que o sujeito aceita certos valores sociais ou organizacionais, padrões estéticos e sistemas de idéias, semelhantes ou modificados singularmente a partir da cultura social ou organizacional, como sendo próprios dele. Assim, um valor cultivado em uma organização de Terceiro Setor, como a "paciência com os colegas", passa a ser visto pelo sujeito como um padrão de comportamento - que ele deve adotar neste grupo social - compatível com seu sistema pessoal de crenças e valores.

O processo de motivação está associado ao traçado de objetivos e à escolha de objetos, sendo que as necessidades fisiológicas, as tendências e os schemata, ao mesmo tempo, impulsionam o sujeito e o influenciam na escolha de alguns objetos, em detrimento de outros e, também, no traçado de metas. Nem sempre as influências dessas três categorias encontram-se alinhadas, o que pode ser fonte de sofrimento e conflito interno. 
Para atingir os objetivos do projeto (motivo), o sujeito realiza ações que não estão isentas da influência do meio. Elas podem ser impedidas ou contingenciadas por atores sociais ou pelo ambiente. Se o fenômeno ocorre sem o assentimento do sujeito, dá-se uma coerção, que pode gerar uma dinâmica de resistência ou submissão por parte do sujeito. Esta proposta distingue, portanto, a ação motivada da ação constrangida.

Essa ação não é mera execução de um projeto, por possibilitar que seja modificado na medida em que seu curso gera novas informações e suscita afetos que são percebidos e avaliados pelo sujeito.

A figura 11 sintetiza os processos propostos de cultura e motivação, integrando-os em um modelo geral.

AMBIENTE FÍSICO, SOCIAL E CULTURAL

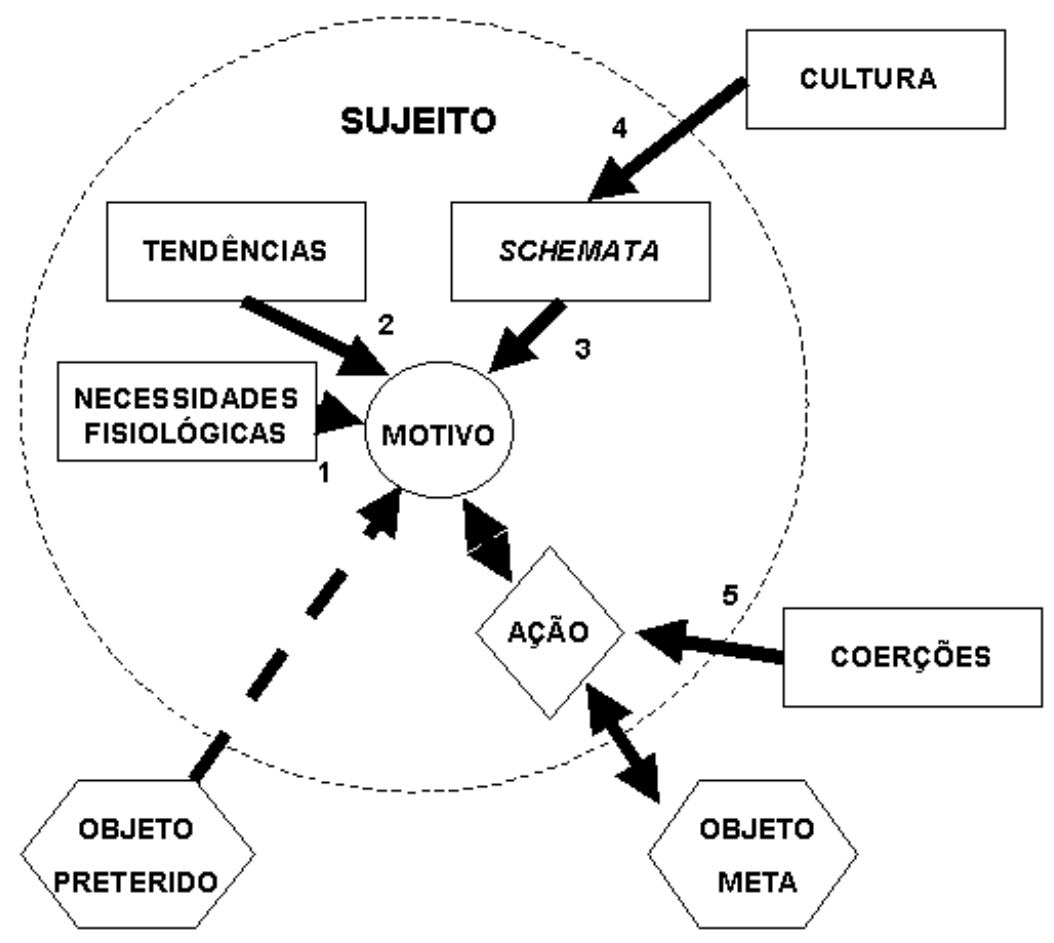

Figura 10: Dinâmica da motivação 
Legenda:

Mecanismo 1 - Homeostase/redução de tensões

Mecanismo 2 - Energização

Mecanismo 3 - Identificação

Mecanismo 4 - Assimilação Ativa

Mecanismo 5 - Resistência/submissão

Como foi visto, não há bases empíricas que possibilitem sustentar a teoria da hierarquia da preponderância das necessidades não fisiológicas de Maslow, que se encontram fundidas nas diferentes tendências deste modelo.

O presente modelo não é capaz de dimensionar o peso da influência dos elementos constituintes. Estes servem mais como categorias de análise, a demandar do pesquisador de motivação uma atenção dirigida a pontos variados que circundam a construção dos "projetos de ação" das pessoas.

O modelo de análise proposto parte do conceito de motivação como um projeto de ação baseado nas relações requeridas entre o meio (objeto-meta) e o sujeito, construtor do projeto e influenciado por elementos de nível fisiológico, psicológico e sociocultural, bem como coagido por mecanismos de controle social e ambiental (coerção).

5.1.5 Metodologia de estudo da motivação.

Os motivos se acham associados a relatos de experiência de satisfação e de frustração, articulados à colocação de metas que o sujeito se faz. Esta é a via escolhida para o seu estudo. 
A metodologia de história de vida é uma estratégia importante para o estudo da motivação do sujeito, porque permite a apreensão da habitualidade das experiências de satisfação e frustração e a análise das escolhas e projetos nos quais o sujeito se engajou.

Não há como se furtar à análise do sentido e do significado subjetivo da narração do sujeito, e é privilegiada a entrevista individual e a interlocução, para que o pesquisador compreenda o sentido dado pelo sujeito às suas escolhas, satisfações e insatisfações.

A fenomenologia é um bom arranjo metodológico qualitativo para o estudo das motivações subjetivas, porque critica a análise superficial de discurso, remetendo o pesquisador à suspensão de juízo e à busca das essências, como o faz Nuttin em sua teoria da motivação.

Assim como Nuttin, prefere-se essa metodologia aos estudos experimentais, em que os motivos seriam eliciados ou privados, especialmente porque o controle de variáveis seria prejudicado pela sobredeterminação das ações; bem como ao uso de questionários, em que se fica refém dos conceitos aceitos socialmente e das précategorizações. São necessários estudos subjetivos profundos de voluntários em organizações de Terceiro Setor, antes de se ceder à "tentação" de criar categorias gerais de motivação.

5.1.6 A superficialidade dos estudos sobre motivação de voluntários

A análise do voluntariado já possui estudos relacionados à motivação. Este tipo de recorte permite à pesquisa analisar um vínculo entre pessoa e instituição que não se ache mediado pela remuneração financeira. 
Schlinder-Rainman (1980) desenvolveu um trabalho baseado no modelo de Kurt Lewin, no qual identifica fatores motivacionais relacionados à decisão de voluntariar-se, e à decisão de permanecer voluntário. Dentro deste modelo, ela distingue fatores pessoais, interpessoais e situacionais.

A partir desse trabalho, a autora conclui que:

a) o principal fator de motivação para voluntários é a oportunidade de participar da solução de problemas e de processos de decisão importantes;

b) a colocação de voluntários deve incluir alguns processos que permitam relacionar o tipo de trabalho e a situação dos interesses particulares, necessidades e motivações dos candidatos;

c) para aumentar a motivação, a maioria das oportunidades dos voluntários deve possibilitar o desenvolvimento da auto-atualização pessoal e o serviço significativo para as necessidades dos outros. Em outras palavras, as oportunidades para oferecer serviço voluntário devem ser apresentadas tanto como oportunidades de educação continuada, de aprender e crescer quanto oportunidade de contribuir cada um com sua parte para o tão necessário serviço social;

d) o "contrato" entre o voluntário e a organização deve legitimar o nível possível de comprometimento e permitir variações pessoais no tempo, energia e interesse, sem culpa ou tensão sobre divisão de lealdades e limitação de energias;

e) a experiência em serviço do voluntário deve incluir oportunidades continuadas para estudos reflexivos e avaliação, para planejamento conjunto e determinação dos objetivos do serviço e das ações. Muito do que sustenta o voluntário e renova a sua motivação vem da visão clara de passos através dos objetivos de grupo e da realização sucessiva de todos eles, um a um; 
f) as necessidades podem ser encontradas e a motivação sustentada mais efetivamente se a situação de trabalho também permite o avanço individual por meio de uma seqüência de passos que conduzam a níveis mais altos de responsabilidade, habilidades, aprendizado e influência;

g) para muitos voluntários, a motivação será aumentada se o registro de atividades que é mantido vier a tornar-se parte de seu currículo e puder conduzi-los ao serviço remunerado;

h) a motivação será sustentada melhor se houver mecanismos regulares de "feedback" de clientes, colegas e lideranças profissionais, e pelo reconhecimento da agência e da comunidade;

i) a participação em atividades de treinamento significativas dentro e fora da organização (por exemplo, conferências) é uma fonte importante de motivação continuada e de crescimento. (SCHINDLER-RAINMAN, 1980)

Embora ambientado no cenário americano, esse trabalho delimita questões próprias da realidade do trabalho voluntário, e permite tecerem-se considerações sobre a gestão do mesmo. Um limite desta proposta está no fato de a autora propor que existem fatores gerais associados ao trabalho voluntariado, evitando traçar diferentes perfis subjetivos. Ela prefere fazer recomendações universais. O estudo realizado nesta pesquisa mostrou que há diferentes arranjos subjetivos de tendências, variações nos schemata e diferentes motivos construídos por voluntários em um mesmo espaço organizacional, como se pode ler no capítulo 10.

Coelho (2000, p. 12) em sua pesquisa fez uma breve incursão, sem maior profundidade, no tema da motivação de voluntários em creches brasileiras. Ela afirma que os principais motivos alegados pelos voluntários brasileiros são razões altruísticas e 
interesses próprios, diferentemente da realidade americana, onde o trabalho voluntário é incentivado por empresas privadas, que o consideram como um diferencial no curriculum dos candidatos, em decorrência da visão que se tem desse tipo de trabalho como elemento formador de mão-de-obra e existência de "benefícios pessoais indiretos" (COELHO, 2000, p. 73). Vê-se que os motivos apresentados são apenas "razões alegadas", ficando na superficialidade da questão.

Mascarenhas e Zambaldi (2002) fizeram um estudo empregando entrevistas e análise de documentos, em um banco brasileiro que incentiva programas de voluntários. Eles se detiveram ao discurso manifesto e chegaram às categorias de análise expostas no quadro sete. Eles também se mantiveram na superfície dos fenômenos de motivação, por analisar apenas o discurso explícito de seus sujeitos. Em diversas áreas das ciências humanas e sociais (Psicologia, Psicanálise, História, Antropologia, etc.) distingue-se bem a imagem social que o sujeito constrói para apresentar-se e ser aceito socialmente dos fenômenos "internos" e traços da personalidade. Uma pessoa pode dizer que acha socialmente importante ser voluntária, quando, intimamente, está sendo mobilizada por outros interesses e tendências.

O estudo também apresentou motivos alegados, mas não é conclusivo quanto à dinâmica do voluntário. O voluntário é mobilizado apenas por um desses motivos ou pode haver a ação de mais de um motivo ao mesmo tempo? Esses autores também não superaram a limitação do anterior, por não aprofundarem o nível das "razões apresentadas". 
Quadro 7: Motivações de voluntários

\begin{tabular}{|c|c|}
\hline \multicolumn{2}{|c|}{ Grupo de motivações altruístas } \\
\hline Motivações altruístas e ideológicas & $\begin{array}{l}\text { Voluntários declaram que o desejo de ajudar o próximo } \\
\text { é justificado por uma forte convicção em relação aos } \\
\text { problemas a serem solucionados. }\end{array}$ \\
\hline \multicolumn{2}{|c|}{ Grupo de motivações egoístas } \\
\hline Motivações de crescimento pessoal & $\begin{array}{l}\text { A experiência é uma grande aprendizagem, pois } \\
\text { proporciona novas visões de mundo, contato com } \\
\text { novas realidades e novas lógicas de pensamento. A } \\
\text { experiência adquirida pelos voluntários leva também à } \\
\text { mudança em sua autopercepção, já que sua realidade é } \\
\text { constantemente comparada à realidade do outro. }\end{array}$ \\
\hline Motivações de status & $\begin{array}{l}\text { Segundo os voluntários, o uso e desenvolvimento de } \\
\text { habilidades profissionais são benefícios adquiridos com } \\
\text { a experiência. A percepção dos funcionários é de que } \\
\text { eles têm um espaço privilegiado para o treinamento e o } \\
\text { aperfeiçoamento de suas habilidades, tão importantes } \\
\text { para a sua empregabilidade. }\end{array}$ \\
\hline Motivações sociais & $\begin{array}{l}\text { O voluntário se evidencia com a atuação nos programas } \\
\text { sociais, pois acaba conhecendo muitas pessoas dentro } \\
\text { do próprio banco, aumentando sua cadeia de } \\
\text { relacionamentos. Ao se conhecer o trabalho e as } \\
\text { capacidades de outras pessoas, revelam-se } \\
\text { oportunidades da utilização de talentos, muitas vezes } \\
\text { inesperadas. }\end{array}$ \\
\hline Motivações materiais & $\begin{array}{l}\text { A valorização dos voluntários vem através da } \\
\text { apreciação das características da personalidade da } \\
\text { pessoa pelo RH. Há a percepção de que a experiência } \\
\text { de uma atividade voluntária no currículo é valorizada } \\
\text { tanto por escolas de MBA como pelas empresas. } \\
\text { Apesar das ambigüidades nos discursos, as visões dos } \\
\text { funcionários e do RH estão alinhadas. }\end{array}$ \\
\hline
\end{tabular}

Fonte: Mascarenhas e Zambaldi, 2002.

Como se pode ver, mais que um quadro categorial que comporte "razões alegadas", o estudo da motivação no trabalho voluntário em OTS demanda um referencial teórico complexo o suficiente para entender a dinâmica das escolhas do sujeito, membro de um movimento, situado em uma organização.

Esse tipo de conhecimento permite não apenas a compreensão das escolhas individuais, mas a análise de grupos de trabalho e o redesenho dos espaços ocupacionais das OTS e de seus processos de gestão para acomodar voluntários diferentes, com projetos diferentes, trabalhando conjuntamente por um objetivo comum e partilhado. 
Essa é uma das possibilidades do modelo teórico desenvolvido, que se pretende testar em uma realidade social concreta.

5.2 Uma proposta de modelo de pesquisa de cultura para organizações de Terceiro Setor

Uma singularidade que as organizações de Terceiro Setor costumam ter, em comparação com as de Mercado ou Estado, é a sua vinculação a um movimento religioso, político ou social. Geralmente esses movimentos possuem uma construção própria de ethos e visão de mundo, mais ou menos permeável aos valores da sociedade em que se situa.

\subsubsection{Níveis de análise de cultura}

Uma vez tornado membro do movimento, é compreensível que o ator social espere que a organização seja um espaço de partilha das crenças, idéias e valores aceitos no movimento de origem. Como este tipo de espaço social não é caracterizado, de uma forma geral, pela instrumentalidade, mas pela substancialidade, pode haver uma dissonância entre as propostas de técnicas de gestão, que têm por propósito a preocupação com eficiência, eficácia ou efetividade, e a idealização que o membro do movimento (incluindo aí o fundador e os diretores da organização) faz do papel da organização e do seu papel nela.

Enquanto universos fechados ou que privilegiam a atuação dos membros destes movimentos em suas organizações, há que se considerar uma nova instância da análise cultural: em nível de movimento religioso, político ou social. 
Sob esta ótica, o pesquisador necessita compreender, por uma observação acurada, qual é o papel da organização de Terceiro Setor. Isto significa que um asilo pode não ser apenas um asilo, mas um espaço pensado para se ter uma experiência religiosa $^{58}$; uma organização de advocacy pode ter também o sentido de ser um aparelho para a construção de uma sociedade democrática e inclusiva, etc. Isto pode ser explícito e fruto da elaboração consciente dos fundadores ou apenas um pressuposto básico, aceito pela grande maioria dos membros, mas não explicitado nos seus documentos, ritos e processo de socialização.

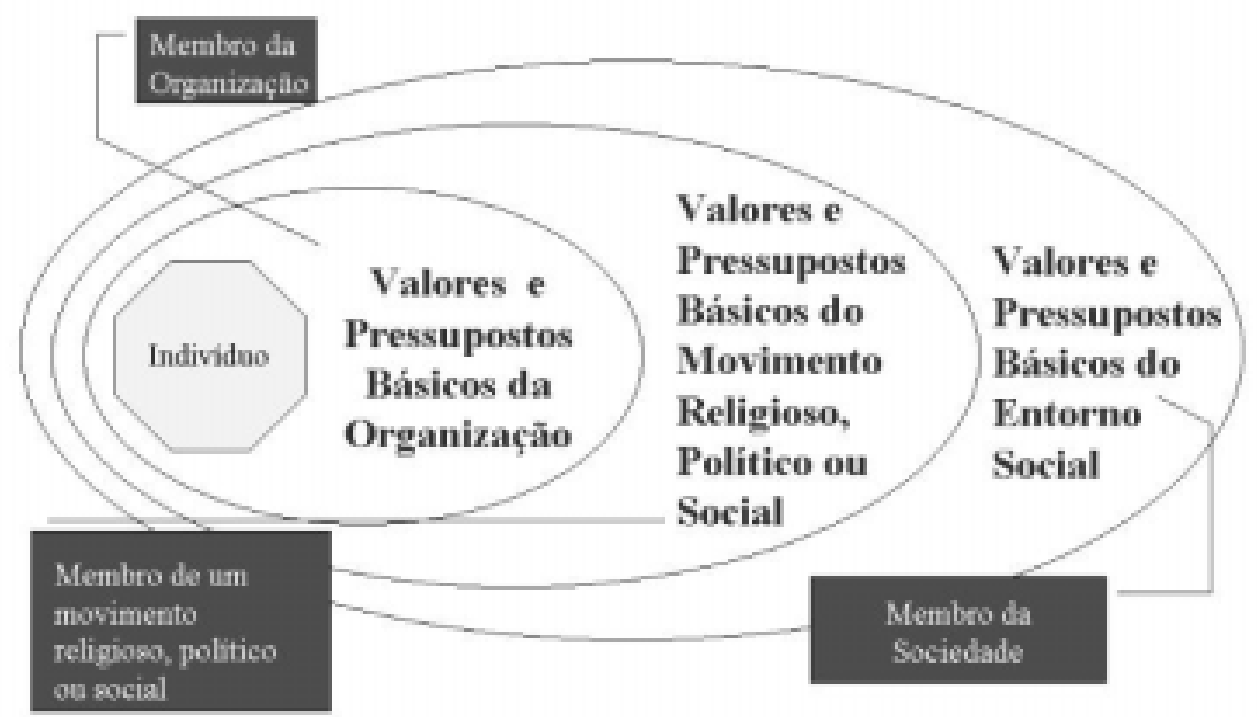

Figura 11: Níveis de análise da cultura de uma organização de Terceiro Setor

Embora o ethos e visão de mundo dos movimentos possam coadunar-se com os objetivos instrumentais da administração, enquanto pressupostos básicos, eles costumam gerar pontos de conflito com as propostas gerenciais, pelo entendimento dos

\footnotetext{
${ }^{58}$ É o que se encontra, por exemplo, no discurso de Madre Tereza de Calcutá sobre a sua experiência religiosa lavando os intocáveis indianos para que tivessem uma morte digna.
} 
atores organizacionais de que estas viriam a esvaziar a organização do seu sentido profundo. Essa questão foi percebida, mas tem sido tratada de forma tangencial pelos autores que têm se empenhado em construir uma administração do Terceiro Setor ${ }^{59}$.

5.2.2 Análise cultural em nível de movimento político, religioso ou social

Neste nível, as categorias de Geertz (1989) de visão de mundo e ethos permitem uma análise mais ampla, subjacente e capaz de dar base de compreensão aos laços de relacionamento da cultura organizacional.

Além dessas duas categorias e seus respectivos desdobramentos, é igualmente útil a análise do ideário cultural do movimento para procurar sentido e recomendações para os processos de gestão da organização como um todo.

5.2.3 Abertura da organização à comunidade e a outras esferas da sociedade

Outra implicação clara da existência de um movimento político, religioso ou social subjacente à organização é a sua abertura a outras esferas sociais, de pessoas não identificadas com este movimento.

Essa abertura pode ser restrita, profunda ou inexistente, entendendo-se o primeiro termo como a existência de interfaces com outras esferas sociais que não interfiram nos processos internos de gestão da organização; o segundo, como a interlocução e realinhamento das decisões da organização a partir da participação de parceiros de outras esferas sociais e o terceiro, como a total ausência de relações fora do movimento de origem.

\footnotetext{
${ }^{59}$ Cf. ROESCH 2002.
} 
Como exemplo, uma organização que tenha por ponto de contato apenas organizações financiadoras, cujas relações são negociadas contratualmente, é considerada como de abertura superficial. Uma creche de associação de bairro que tivesse a participação dos membros da comunidade onde atua (e não apenas dos membros da referida associação), que lá se inserissem como voluntários e partícipes de um conselho de classe, com poder efetivo para tomada de decisões, ilustraria uma organização de abertura profunda. As organizações fechadas não possuem qualquer troca com o universo externo ao seu movimento de base, exceção feita à consecução de seu objeto social.

\subsubsection{Análise da cultura organizacional}

Neste nível de análise, as dimensões propostas por Fleury à metodologia de Schein são apropriadas ao entendimento da cultura organizacional de OTS. Precisaria ser considerada a possibilidade de existência de um segmento especial de atores, que são os voluntários e que não podem ser confundidos com os empregados, dada a singularidade do seu vínculo e do sentido do trabalho para eles.

As organizações de Terceiro Setor não estão isentas da influência de relações de poder, como se poderia supor, mas há que se identificarem as arenas de disputa e o objeto do poder político.

Ficam, portanto, as seguintes dimensões analíticas:
a) história da organização com ênfase ao fundador e às crises;
b) processo de socialização de novos membros;
c) políticas de gestão de pessoas;
d) processos de comunicação; 
e) organização do processo de trabalho.

Um ponto importante, com relação ao fundador, seria a compreensão clara de qual é o seu "sonho", qual foi a sua intenção ao criar uma organização que não visa a lucro. Esse desejo original pode ser a chave para a compreensão de alguns dos pressupostos básicos dessa organização e da lógica de suas relações de trabalho.

Uma ênfase adicional a ser dada aos processos de gestão de pessoas repousa sobre os processos de tomada de decisão. Alguns autores ${ }^{60}$ acusam esse tipo de organização de ser caracterizada pela irracionalidade nos processos de decisão. Neste trabalho, questiona-se se existe esta irracionalidade ou se as organizações convivem com lógicas alternativas, em que o poder, os valores originais, a sustentação dos heróis organizacionais ou outro referente são mais importantes que o objetivo formal da mesma.

Com este modelo composto de categorias analíticas que articulam cultura, cultura organizacional e motivação, pretende-se analisar em profundidade um caso concreto de organização de Terceiro Setor de distribuição de bens e prestação de serviços, que atende aos objetivos da pesquisa. Longe de pretender validar este modelo com esta estratégia, busca-se realizar uma primeira aplicação, capaz de explorar sua consistência interna, suas possibilidades analíticas e suas limitações para o emprego em outras OTS.

\footnotetext{
${ }^{60}$ BOBBIO, 1982.
} 


\title{
6. METODOLOGIA DE PESQUISA
}

\begin{abstract}
- O homem é um bicho esmochado, que não devia haver. Nem convém espiar muito para o homem. É o único vulto que faz ficar zonzo, de se olhar muito. É comprido demais, para cima, e não cabe todo de uma vez, dentro dos olhos da gente ${ }^{61}$. - João Guimarães Rosa.
\end{abstract}

\subsection{Bases epistemológicas da pesquisa}

Existe um debate amplo na esfera da Epistemologia, ainda em curso, no qual se discute o caráter do conhecimento científico. Trata-se de questões complexas, com uma longa tradição e diversidade de escolas de pensamento que se posicionam de forma diferenciada em relação a muitos pontos, cuja apresentação foge ao escopo do traçado metodológico desta pesquisa. Publicou-se ${ }^{62}$ anteriormente um trabalho que mostra as diferenças epistemológicas entre a tradição fenomenológico-hermenêutica de pesquisa, especialmente desenvolvida em meio às ciências humanas e sociais, e a tradição empírico-formal, originalmente desenvolvida em meio às ciências naturais.

As ciências fenomenológico-hermenêuticas são ciências da interpretação e segundo Zilles (1994, p. 164) "visam à realidade humana enquanto apreensível, enquanto perceptível na natureza transformada pela cultura" e visa à subjetividade, à singularidade, trabalhando essencialmente com "a categoria do sentido".

As ciências empírico-formais têm por objeto a realidade empiricamente apreensível (natureza) e procuram traçar nexos de causalidade simples ou complexos, estabelecer relações constantes entre fenômenos (leis naturais), que possibilitem ao

\footnotetext{
${ }^{61}$ Trecho extraído do conto "Conversa de Bois", do livro Sagarana.

${ }^{62}$ SAMPAIO, 2001.
} 
homem, em última instância, a predição e o controle da natureza. Elas desenvolveram, portanto, um instrumental metodológico voltado ao estabelecimento de regularidades.

Existe um debate nos meios científicos, mais acirrado em meio às ciências humanas e sociais sobre a validade de um ou de outro arranjo metodológico. Na defesa de suas posições metodológicas, eles acabam por adotar uma visão de homem que favoreça suas crenças pessoais. Desta forma, o cientista simpatizante da tradição empírico-formal tenta defender a concepção mecanicista, e por vezes determinista, do ser humano. Por outro lado, o simpatizante das posições fenomenológico-hermenêuticas tende a conceber o ser humano como construtor de sua própria identidade, e, portanto, das organizações e instituições sociais, sendo possível ao pesquisador apenas compreendê-lo, ou seja, não explicá-lo ou prevê-lo.

Neste trabalho, adotar-se-á uma visão de homem complexa, em que ele é ao mesmo tempo um ser de natureza e de cultura, construtor e construído pelas instituições e organizações a que pertence.

Por extensão, entende-se que as organizações são simultaneamente construtoras e construídas pelos homens, influenciadas por forças do ambiente econômico e político, mas não necessariamente subjugadas por elas. É possível identificar algumas regularidades e tendências organizacionais, mas a ação humana pode alterar a lógica de funcionamento e as instituições que dão suporte às regularidades identificadas em pesquisa.

\subsection{Classificação da pesquisa}

Os autores de metodologia da pesquisa científica em Ciências Sociais possuem diversos termos para classificação de pesquisas, mas não há ainda uma 
padronização internacional ou algo semelhante. Há diversos critérios de classificação, como o objetivo da pesquisa, sua base epistemológica ou os seus procedimentos técnicos e analíticos.

Gil (1987) adota o termo design, empregado pelos autores de língua inglesa, que ele traduz por delineamento, para classificar a pesquisa a partir de seus procedimentos técnicos e de planejamento. De Bruyne (1991) desenvolveu um modelo complexo de avaliação da pesquisa no qual denomina "modo de investigação" o tipo de classificação que hora se faz. Yin (2001) prefere denominá-la de estratégia de pesquisa, porque entende que essa forma de classificar já comunicaria ao leitor que a pesquisa não se baseia apenas em uma técnica, mas, exige uma sequiência de escolhas ou um projeto de técnicas de coleta, análise e interpretação de dados. Becker (1994), por sua vez, prefere empregar o termo métodos de pesquisa, que é uma escolha polêmica, porque muitos pesquisadores e epistemólogos preferem reservar o termo método para referirem-se ao método científico, baseando-se na teoria da unicidade da ciência.

Independentemente da escolha que façamos, todos estes autores concordam que o tipo de pesquisa que se fez neste trabalho pode ser denominada "estudo de caso", mas é necessário definir e explicitar melhor as escolhas efetuadas e a construção do projeto para que o leitor entenda como se deu aqui a construção do conhecimento.

\subsection{Estudo de caso}

Embora amplamente empregados em ciências humanas e sociais, os estudos de caso são ainda objeto de alguma polêmica quanto ao seu emprego e limites.

De Bruyne (1991, p. 224) o define como "uma análise intensiva, empreendida numa única ou em algumas organizações reais", que "reúne informações 
tão numerosas e detalhadas quanto possível, com vistas a apreender a totalidade de uma situação". Becker (1994) adita que este método supõe ser possível adquirir conhecimento a partir "da exploração intensa de um único caso", e que ele teria uma dupla finalidade: a "compreensão abrangente do grupo em estudo" e o desenvolvimento de "declarações teóricas mais gerais sobre regularidades do processo e estrutura sociais".

Assim, constatam-se quatro elementos essenciais em um estudo de caso: a análise em profundidade de uma unidade de pesquisa determinada; a possibilidade de gerar novos conceitos e construtos analíticos referentes ao seu objeto de estudo; a possibilidade de triangulação entre dados objetivos (fontes empíricas) e subjetivos (fontes fenomenológicas) no processo de análise e certa possibilidade de generalização não-estatística para o campo teórico, limitada pelo princípio da "validade transitória até novas informações" $"$.

\subsubsection{Objetivos do estudo de caso}

Uma vez aceito o caráter do estudo de caso, discute-se quais os seus objetivos possíveis, tema sobre o qual encontram-se divergências entre os diversos pesquisadores.

Uma classificação da pesquisa, com relação aos seus objetivos, considera-a como exploratória, descritiva e explicativa ou explanatória. Esta classificação se acha muito aderente à visão empírico-formal de ciência, e é dificilmente empregada em uma outra base epistemológica sem que se façam concessões. A base fenomenológicohermenêutica, por exemplo, distingue a explicação da compreensão, entendendo que,

\footnotetext{
${ }^{63}$ DE BRUYNE, 1994, p. 227.
} 
para um mesmo objeto da realidade (nous), as pessoas podem dar diferentes sentidos (fenômenos), o que ao mesmo tempo resgata a visão de homem como ser cognoscente e delega ao cientista o papel de buscar as essências dos fenômenos, o que só se consegue fazer com ação intersubjetiva.

Não há polêmicas entre os autores no reconhecimento do estudo de caso como um método vigoroso para a exploração, a descrição e a compreensão. Aceita-se, também, que os estudos de caso podem ser utilizados para finalidades utilitaristas, como no estabelecimento do "diagnóstico de uma organização" na sua avaliação ou no estabelecimento de uma terapêutica ou mudança desta ${ }^{64}$. Eles divergem, entretanto, na aceitação deste método como vigoroso o suficiente para a realização de estabelecimento de nexos causais (explicação). Yin (2001) defende, em seu trabalho, que o estudo de caso pode ser explicativo, e argumenta que da mesma forma que, em uma pesquisa experimental, nem todas as estratégias de pesquisa se fundam na generalização estatística, como se faz em um levantamento ou pesquisa de opinião, e que nem por isso sua proposta causal perde o seu valor. Por princípio, ele se apóia na noção de ciência como falível (FERRARI, 1982, p. 10), uma espécie de conhecimento transitório, para defender a idéia de que uma proposição de causalidade pode ser feita até que seja falsificada ${ }^{65}$ por novos estudos. Aceitando-se este princípio, pode-se afirmar, sem problemas, que um estudo de caso bem conduzido pode propor nexos de causalidade válidos no nível teórico subjacente aos fatos e fenômenos analisados, mas que, como qualquer outro método rigoroso, esses terão validade até que outros estudos calcados em métodos científicos mostrem o contrário.

\footnotetext{
${ }^{64}$ DE BRUYNE, 1991, p. 225.

${ }^{65}$ No sentido que POPPER (1999) lhe atribui.
} 
Apesar de sua forte característica exploratória, a presente pesquisa visa a trazer contribuições explicativas e compreensivas. Por exploração, não se entende um estágio pré-científico ou anterior ao estabelecimento de leis, mas, neste estudo, um retorno ao campo, para buscar novas categorias de análise, capazes de permitir a compreensão ou explicação do fenômeno da gestão de voluntários neste tipo de organização específica (uma organização prestadora de serviços do Terceiro Setor).

\subsubsection{Triangulação}

O termo triangulação vem sendo utilizado por diversos autores ${ }^{66}$ para designar diversos tipos de cruzamento de informações, e é um dos recursos utilizados no estudo de caso, para aumento de sua validade e confiabilidade.

Não há entendimento comum sobre a origem do termo. Alguns autores entendem que é uma metáfora oriunda da navegação ${ }^{67}$, outros da demarcação de terras $^{68}$, mas independente disto, ele diz respeito ao emprego de dois ou mais pontos de referência para a orientação. Em navegação, por exemplo, o emprego de sextantes permitiu a identificação da posição da nau a partir da referência construída entre o sol, a lua ou outro corpo celeste e a linha do horizonte.

$\mathrm{Na}$ pesquisa social já foram traçados quatro diferentes tipos de triangulações como se pode ler em Yin (2001, p. 121) e em Fleury, M. T. L., Shiniashiki, G., Stevanato, L.A. (1997a, p. 288): a triangulação de dados, a triangulação de pesquisadores, a triangulação de teorias e a triangulação metodológica.

\footnotetext{
${ }^{66}$ YIN, 2001, p. 121, FLEURY, SHINIASHIKI, STEVANATO, 1997a, p. 288-289, DUNCAN, J., 1989.

${ }^{67}$ SHINIASHIKI, G., STEVANATO, L. A., 1997.

${ }^{68}$ PATTON (1999).
} 
A idéia de triangularem-se dados enriquece a pesquisa e, salvaguardadas as diferenças epistemológicas, permite a articulação de técnicas quantitativas com técnicas qualitativas, possibilitando maior rigor metodológico. Todavia, não é indispensável a existência de fontes qualitativas e quantitativas para se estar empregando uma triangulação de dados.

No presente estudo emprega-se a triangulação de dados, servindo-se das seguintes fontes de coleta de dados para sua realização:

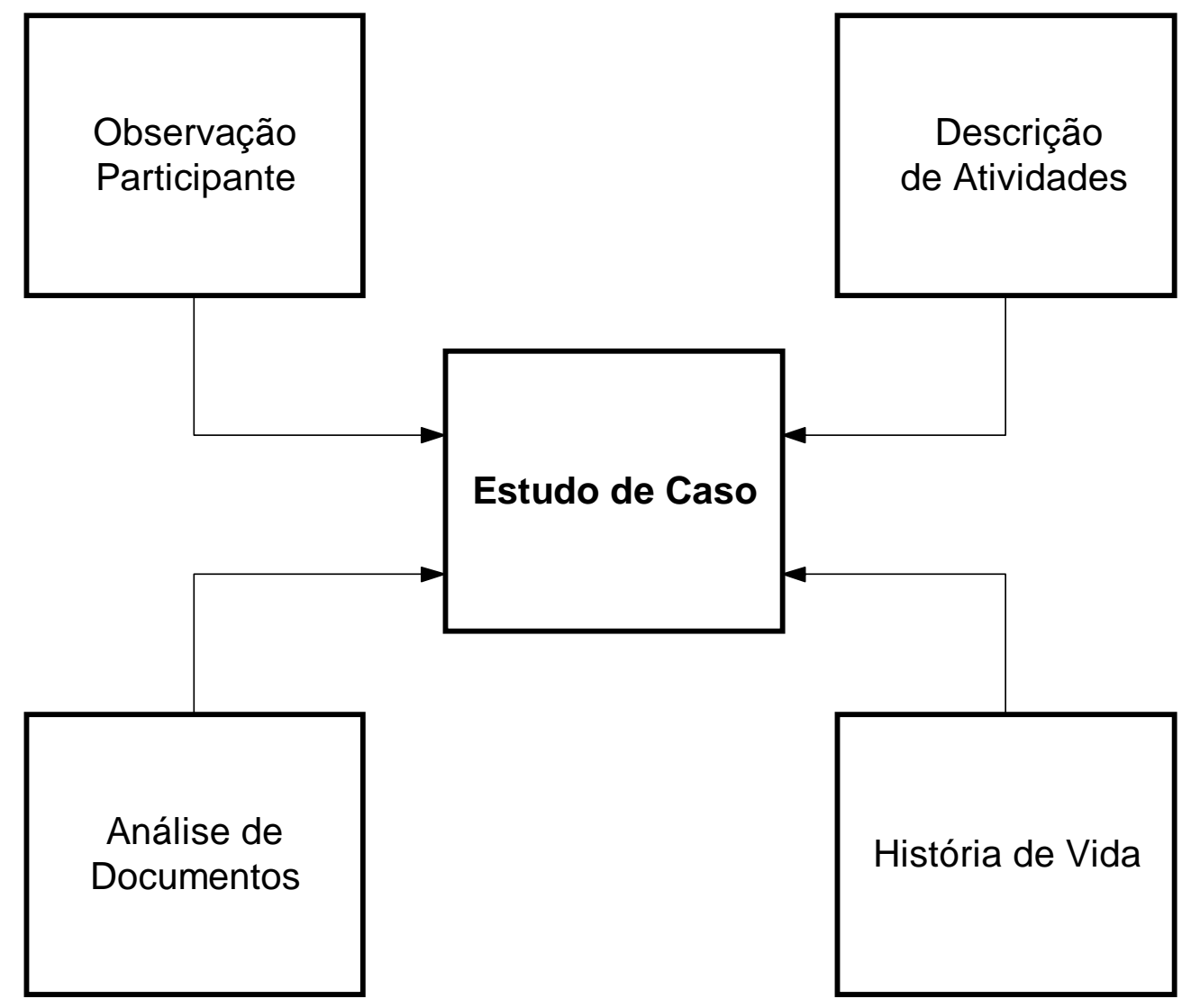

Figura 12: Técnicas de coleta de dados para a realização do estudo de caso.

\subsubsection{A escolha do caso e as unidades de análise}


Yin (2001) aprofundou-se nos estudos sobre as variedades de estudos de caso e destacou diversos pontos diferentes dentro deste método, dentre eles, o número de casos estudados e as unidades de análise.

Quanto ao número, encontram-se estudos que focalizam um único caso e casos múltiplos. Realizou-se um estudo de caso único, e escolheu-se a referida organização por diversas razões: o contato anterior do pesquisador com a organização lhe facultou amplo acesso aos processos, pessoas e informações; a organização possuía uma história anterior na qual havia preocupação de seus gestores com a sistematização de processos de gestão; os arquivos da organização possuíam documentos que possibilitariam a recuperação de sua história a partir desta fonte; a creche era mantida por uma instituição religiosa (o que é muito comum neste segmento do Terceiro Setor); havia uma história de emprego intensivo de pessoal voluntário; houve a opção de estabelecer-se uma parceria com o poder público, o que permitia a análise de alianças intersetoriais. Essas características proporcionavam a análise, em profundidade, de uma organização típica de um dos grandes segmentos do Terceiro Setor brasileiro.

O pesquisador é membro da mantenedora e participou de uma das equipes de desenvolvimento da primeira estrutura organizacional da creche, tendo se afastado posteriormente da Creche Futuro.

Com relação às unidades de análise, o presente estudo pode ser classificado como um estudo de caso incorporado ${ }^{69}$ porque ele pretende abranger três unidades de análise: do nível das pessoas, o corpo de voluntários; do nível organizacional, a estrutura, cultura e padrões de gestão da organização e do nível intersetorial, a aliança com o poder público e com organizações da iniciativa privada.

\footnotetext{
${ }^{69}$ YIN, 2001, p. 64.
} 
A figura 13 ilustra a abrangência e os níveis de análise da pesquisa:

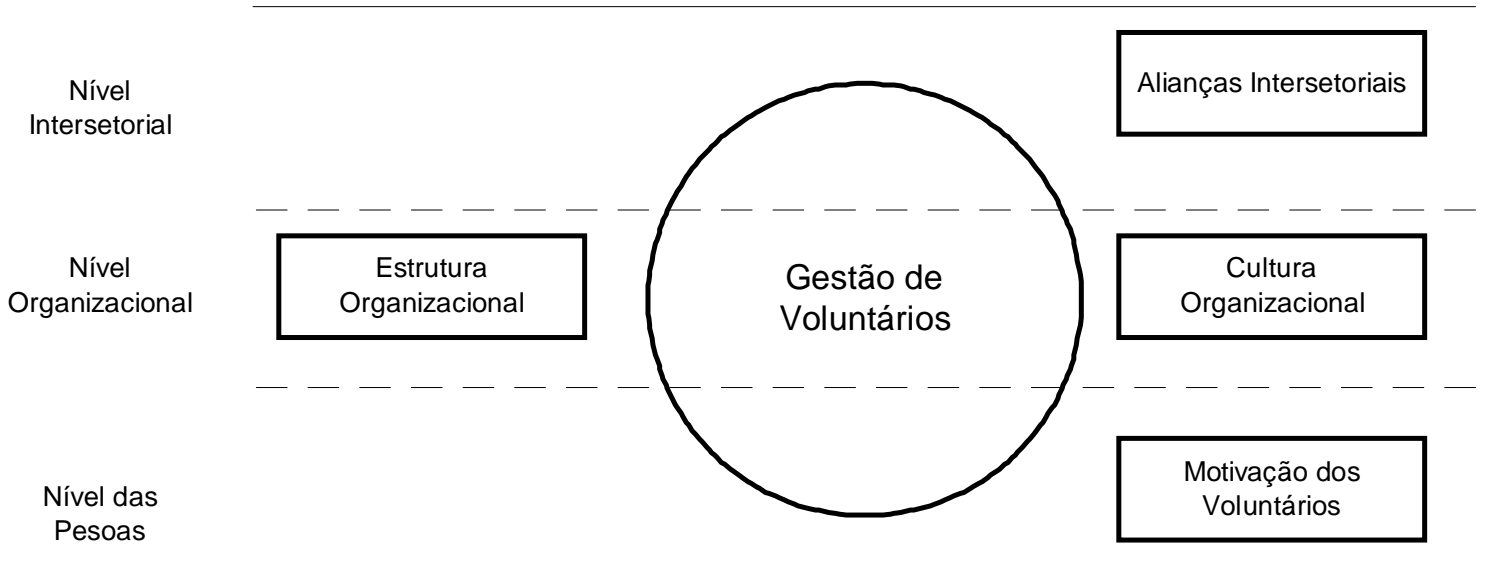

Figura 13: Níveis de análise e focos do estudo teórico.

\subsection{Técnicas de coleta de dados}

Foram empregadas as seguintes técnicas de coleta de dados para a análise da cultura e motivação de voluntários da Creche Futuro:

\subsubsection{Observação participante}

Existe um entendimento já consolidado com relação à observação participativa como um método de pesquisa em Ciências Sociais no qual o pesquisador interage com o grupo social/organização de forma ativa, podendo tornar-se um colaborador deste ${ }^{70}$.

Essa técnica se distingue da observação direta sistemática ${ }^{71}$, porque nela a interação com os membros da organização em estudo se dá através da intersubjetividade, e existe a demanda de explicitação de sentido durante essa interação. Os membros do grupo, portanto, não são meros objetos de pesquisa, mas atores sociais

\footnotetext{
${ }^{70}$ YIN, 2001; BERGER, 1994; DE BRUYNE, 1991; MINAYO, 1995; THIOLLENT, 1997.

${ }^{71}$ DE BRUYNE, 1991.
} 
capazes de explicar suas intenções, desejos e percepções da organização, de forma interativa. Outro ponto importante repousa na possibilidade que essa técnica oferece ao pesquisador de participar das atividades e trabalhos que os sujeitos da pesquisa realizam, o que permite uma percepção diferenciada deles. Um terceiro elemento importante desse tipo de técnica repousa na possibilidade de incorporação de fenômenos inesperados, que surgem para o pesquisador e que confere maiores possibilidades exploratórias que um questionário estruturado ou uma observação calcada em um roteiro pré-estabelecido.

A observação participante pode ser realizada com observador oculto ou não. Optou-se por identificar o pesquisador aos membros da organização pesquisada e explicitar formalmente em reunião, junto aos empregados contratados, que tipo de trabalho se estaria fazendo e qual seria o seu escopo, principalmente para minimizar fantasias e boatos que interfeririam na pesquisa.

Existe uma forte identificação desse tipo de recurso metodológico com o estudo de grupos sociais desfavorecidos, na pesquisa latino-americana ${ }^{72}$ como se lê na citação abaixo:

Na América Latina, a pesquisa-ação foi sobretudo formulada em termos de "pesquisa-participante" e utilizada como instrumento apropriado ao contexto das populações carentes, com seus problemas educacionais, culturais ou de consciência política. (THIOLLENT, 1997, p. 21).

Apesar desta inserção em nosso meio acadêmico, esse mesmo autor se preocupou em reafirmar o emprego amplo da pesquisa-ação em "escolas, empresas, cooperativas, associações diversas" e também junto a organizações e comunidades de populações socialmente desfavorecidas nos países industrializados. Thiollent (1997) propõe também um critério de demarcação entre pesquisa-ação e pesquisa participante,

\footnotetext{
${ }^{72}$ BRANDÃO, 1994; THIOLLENT, 1997.
} 
que permite uma avaliação do alcance do emprego da técnica de observação participante (presente nos dois delineamentos de pesquisa).

“a) "Pesquisa sobre os atores sociais, suas ações, transações, interações", seu objetivo é a explicação.

b) "Pesquisa para dotar de uma prática racional as práticas espontâneas"; seu objetivo é a aplicação.

c) Pesquisa por, ou melhor, pela ação, isto é, assumida por seus próprios atores (autodiagnóstico e autoprognóstico) tanto em suas concepções como em sua execução e seus acompanhamentos"; seu objetivo é a implicação". (THIOLLENT, 1997, p. 37)

A partir dessas três afirmativas, ele considera que a pesquisa-ação se distingue da observação participante porque esta se circunscreveria apenas à pesquisa sobre os atores e a organização. Ao que parece, o sentido do termo explicação é amplo, cabendo nele tanto a explicação clássica do empirismo formal (que se acha relacionada ao estabelecimento de relações entre variáveis) quanto ao sentido de compreensão da fenomenologia (que se acha relacionada ao estabelecimento do sentido, da intencionalidade dos atores e da distinção entre as essências e os fenômenos aparentes). O presente trabalho tem por objetivo o entendimento dos atores sociais na organização em estudo e a descrição dos desdobramentos ocorridos, a partir da análise realizada pelo pesquisador e sua equipe de pesquisa.

Como técnica, a observação participante é adotada amplamente em pesquisa qualitativa, é muito apropriada ao estudo de caso $^{73}$, e não se restringe aos delineamentos de pesquisa-ação e pesquisa-participante.

Minayo (1995, p. 60) entende que há variações dessa técnica e que a observação participante pode ser empregada com centralidade no delineamento da pesquisa ou ser uma técnica complementar em procedimentos de pesquisa multimetodológicos, o que ocorre no presente trabalho.

${ }^{73}$ YIN, 2001. 
Becker (1994, p. 50) descreveu quatro fases distintas no emprego da observação participante. Nas três primeiras o pesquisador seleciona e define "problemas, conceitos e índices", depois realiza controles sobre a "freqüência e a distribuição dos fenômenos", empregando métodos quase estatísticos para incorporar os resultados em um "modelo de organização em estudo". A quarta fase envolve a apresentação de evidências e provas que sustentam as propostas do modelo proposto. Esse arranjo metodológico baseia-se na exclusividade ou centralidade dessa técnica no processo de pesquisa, o que não acontece no presente estudo, mas considerar-se-ão os cuidados que Becker propõe para a validação das proposições oriundas desta observação participante, que são:

a) Tomar os depoimentos como "evidências sobre o acontecimento" e não "em si”. Um ponto de vista de um sujeito sobre um determinado fenômeno não determina o caráter ontológico do fenômeno;

b) Cuidar para que as perguntas do pesquisador não direcionem uma opinião dos membros do grupo, ou seja, evitar "colocar palavras na boca" dos sujeitos da pesquisa;

c) Verificar se os fenômenos constatados topicamente são "típicos e disseminados" ou se são próprios de um grupo específico. Verificar como estão distribuídos pelos subgrupos ou unidades da organização;

d) Evitar que a participação comprometa o distanciamento necessário do pesquisador para realizar seu trabalho, que prejudique as anotações e análises necessárias à realização da pesquisa. Minayo (1995) também aponta esse cuidado e o seu oposto, o do excessivo distanciamento do grupo pelo pesquisador, a ponto de dificultar sua interação com os atores sociais. 
Um dos recursos empregados para o registro de informações oriundas desse tipo de técnica de coleta de dados foi a redação de um diário de campo. Nele se registraram os eventos que houve no decorrer da pesquisa, como as reuniões e comentários dos atores organizacionais, procurando identificar datas e situações para, posteriormente, poder utilizar como evidências, no corpo do trabalho.

A observação participante envolveu três fases, a saber:

\subsubsection{Entrada na organização}

Foi feito um contato inicial com o superintendente e o coordenador administrativo da Creche Futuro e foram explicitados os interesses e necessidades da pesquisa e os possíveis benefícios da organização, ao acolhê-la. Uma vez demonstrado o interesse desta instância, marcou-se uma reunião com a diretoria da mantenedora. Nesta reunião, em que se obteve autorização para a pesquisa, foram explicitadas as atividades que seriam feitas na creche e foi acordado o sigilo dos resultados obtidos.

\subsubsection{Análise Organizacional}

A análise organizacional foi realizada com o apoio de um grupo de estagiários de Psicologia do Trabalho da Universidade Federal de Minas Gerais. Eles se reuniam semanalmente na Creche Futuro, sob a supervisão do pesquisador, para treinamento, definição de atividades e avaliação das atividades realizadas. Cada estagiário dedicou pelo menos quatro horas semanais, além das horas de supervisão, para a realização de suas tarefas. A equipe de estágio, sob a supervisão do pesquisador, fez uma visita à organização; analisou o organograma formal; construiu uma nova estrutura organizacional para ser proposta (da Creche e da Mantenedora); realizou a 
descrição de atividades da organização ${ }^{74}$ e, ao mesmo tempo em que fez uma pesquisa de interesse em trabalho voluntário, redigiu um documento que continha a descrição de atividades; identificou os conflitos e inconsistências das atribuições; desenvolveu um treinamento introdutório para a organização e propôs a criação de novos grupos de voluntários ligados, principalmente, ao Departamento de Creche. O pesquisador redigiu um relatório com os resultados do trabalho no qual fez recomendações à organização, que passaram a ser objeto de discussão no Conselho de Classe da mesma. Nessa etapa, além do treinamento e supervisão dos estagiários, o pesquisador empreendeu a análise de documentos da organização, descrita no item 6.4.2.

\subsubsection{Reuniões com as diretorias e entrevistas com os voluntários}

Foram realizadas reuniões com o Conselho de Classe para apresentar os resultados do trabalho de pesquisa e possibilitar a deliberação dos programas. As reuniões foram objeto de registro no diário de campo, que contém os participantes, as propostas, as deliberações e os principais comentários realizados nessas reuniões.

Ao mesmo tempo em que se fizeram as reuniões, adaptou-se a metodologia de história de vida à realização de entrevistas com os voluntários de um dos territórios de influência da organização escolhido. Essas entrevistas foram a principal fonte de informações para o capítulo de motivação dos voluntários.

\footnotetext{
${ }^{74}$ Ver modelo do instrumento no anexo 2
} 
6.4.2 Análise de documentos

Essa etapa envolve a análise de documentos primários e secundários, necessários à apreensão da história da organização, de alguns elementos de sua cultura, da sua estrutura e dos processos de gestão.

Foram utilizados os boletins da associação mantenedora, o estatuto, os regimentos, as atas de reunião de diretoria e do conselho eleitor e consultivo, os livros referentes à fundação da mantenedora, a legislação referente ao Terceiro Setor e à educação pré-escolar, os relatórios da mantenedora, alguns relatórios de supervisoras, alguns balancetes de verificação, os demonstrativos de resultado de exercício da mantenedora, entre outros que foram considerados indispensáveis.

Na maioria deles, fez-se uma leitura compreensiva e a imediata transcrição dos elementos de identificação e dos conteúdos referentes à pesquisa, uma espécie de fichamento digital.

\subsubsection{História de vida}

A história de vida surgiu na década de 30 do século passado, na Europa, e ganhou notoriedade nos trabalhos de sociólogos americanos da Universidade de Chicago. (BECKER, 1994)

Trata-se de uma técnica que permite a manifestação da subjetividade, que se dá através da narrativa e da expressão dos pontos de vista do participante, na primeira pessoa. É uma técnica de intersubjetividade, posto que permite a compreensão do mundo íntimo do sujeito, a partir de um "relato fiel da experiência e interpretação, por parte do sujeito, do mundo no qual vive”. (BECKER, 1994. p. 102) 
É diferente de uma autobiografia porque o pesquisador tem interesse em conhecer algo da experiência da pessoa que está sendo investigada. Ele, portanto, desenvolve um conjunto de etapas que asseguram a abrangência do que se deseja conhecer e permite que se empreenda esforço para a compreensão da interpretação do sujeito. Os pontos tratados de forma sumária podem ser mais explorados pelo narrador, a partir de demandas do pesquisador, e este pode fazer ligações entre o relato oral e outros registros, bem como de material fornecido por outras fontes.

Nesta perspectiva, a interpretação dada pelo sujeito aos eventos componentes da sua experiência ganha destaque (BECKER, 1994. p. 103).

Esse método nos parece mais adequado para a pesquisa da experiência subjetiva das motivações de voluntários por diversas razões:

a) É mais provável que se entendam melhor as escolhas, satisfações e insatisfações de um sujeito que narra a sua história, assim como suas respostas emocionais, que através de um roteiro de entrevistas, pelo qual, quanto mais dirigido, maior a possibilidade de obterem-se respostas socialmente aceitáveis e nada esclarecedoras como: "eu me voluntariei porque gosto da atividade", ou "porque é importante", etc;

b) É um método que permite a associação entre os motivos alegados e a trajetória do sujeito, percebendo mudanças na dinâmica da motivação;

c) É um método associado a uma concepção de ser humano dotado de uma vida interior, capaz de escolhas não necessariamente racionais;

d) Ele permite, com mais facilidade, a percepção de contradições, conflitos e defesas dos sujeitos;

e) Evita a "naturalização" de aspectos humanos e sociais. 
Alguns pesquisadores distinguem a história de vida dos métodos de história oral (BARROS e SILVA, 2002, por exemplo) distinguem a metodologia de história de vida dos métodos de história oral, restringindo, ao máximo, a interferência do pesquisador no discurso do entrevistado que se disporia a contar sua vida, tendo por base apenas uma frase geral como: conte-me a sua vida. Nessa perspectiva, empregouse história oral neste trabalho, uma vez que o pesquisador interagiu com os entrevistados, demandando explicações sobre pontos sumários da narrativa e solicitando que estes tratassem de aspectos que seriam analisados, como as experiências de insatisfação e gratificação, a experiência de voluntariado da família, entre outros.

O roteiro utilizado se encontra no anexo 1.

\subsubsection{Descrição de atividades}

A "descrição de atividades" é uma adaptação da metodologia de descrição de cargos, que foi empregada para o mapeamento das atividades desenvolvidas na $\operatorname{organização~}^{75}$. Ela tem por objetivo a identificação de todas as atividades realizadas na referida organização e serve de base para a proposição de mudanças, bem como de fonte de informação para os principais processos de gestão de pessoas, como a escolha de voluntários, a seleção de empregados, a qualificação de empregados e voluntários, o acompanhamento das pessoas, a remuneração de empregados e a avaliação dos resultados propostos pela organização.

Por atividade, entende-se tanto o conjunto de tarefas realizadas por uma pessoa individualmente (e que serão igualmente realizadas por outras que tenham tal

\footnotetext{
${ }^{75}$ Cf. FISHER, C. SCHOENFELD, L., SHAW, J., 1999; ANTHONY, W., PERREWÉ, P., KACMAR, K., 1999, SCHEIN, E., 1996, MARRAS, 2002.
} 
atividade como atribuição), como o conjunto de tarefas semelhantes realizadas por um conjunto de pessoas em equipe (em que cada pessoa pode vir a realizar qualquer uma das tarefas, pode se especializar em um conjunto de tarefas, mas não tenham que realizar apenas tal ou qual tarefa atribuída à equipe).

Como não se encontraram funções bem delineadas na Creche Futuro, direcionou-se a pesquisa para a identificação das principais atividades que compõem o rol de trabalhos desenvolvidos nesta divisão.

A descrição de atividades foi feita a partir de entrevistas que foram realizadas com os executores das atividades. $\mathrm{O}$ roteiro delas encontra-se no anexo dois. Procurou-se entrevistar o maior número possível de pessoas envolvidas nas atividades, mas em alguns casos, especialmente onde há diversas pessoas com a mesma atividade, optou-se por entrevistar apenas duas ou três; além disso o presente trabalho tinha, por princípio, o respeito ao desejo dos que não quisessem prestar informações sobre o que fazem, o que praticamente não aconteceu.

As atividades foram identificadas a partir de uma apresentação da organização pelo seu superintendente, da análise de seu organograma e de informações colhidas com a coordenadora administrativa, que auxiliou a equipe também nos contatos para as entrevistas e na divulgação do trabalho junto à organização. Nos casos em que se identificaram equipes de trabalho voluntário, em regime semelhante ao dos grupos semi-autônomos, entrevistou-se sempre o coordenador.

O documento resultante desse trabalho permite ao leitor ter uma visão detalhada das principais atividades realizadas, das características pessoais, dos conhecimentos e experiências necessários e desejados para seus executores, assim como 
os principais instrumentos de trabalho usados. Descreve-se também qual é a participação do trabalho voluntário na realização dessas atividades.

6.5 Matriz de técnicas empregadas para o estudo.

O quadro 8 identifica onde as diferentes técnicas de pesquisa foram empregadas para a realização das etapas do estudo de caso.

\section{Quadro 8: Técnicas empregadas para o estudo de caso}

\begin{tabular}{|c|c|c|c|c|c|}
\hline Etapas & $\begin{array}{l}\text { Análise } \\
\text { Bibliográ- } \\
\text { fica }\end{array}$ & $\begin{array}{l}\text { História de } \\
\text { Vida }\end{array}$ & $\begin{array}{l}\text { Diário de } \\
\text { Campo }\end{array}$ & $\begin{array}{c}\text { Análise de } \\
\text { Documen-tos }\end{array}$ & $\begin{array}{l}\text { Descrição de } \\
\text { Atividades }\end{array}$ \\
\hline $\begin{array}{l}\text { Caracterização do } \\
\text { movimento espírita } \\
\text { brasileiro e mineiro }\end{array}$ & $\sqrt{ }$ & & & $\sqrt{ }$ & \\
\hline $\begin{array}{c}\text { Delimitação do Ethos } \\
\text { Espírita }\end{array}$ & $\sqrt{ }$ & & & & \\
\hline $\begin{array}{l}\text { Trajetória histórica da } \\
\text { Creche Futuro }\end{array}$ & & $\sqrt{ }$ & $\sqrt{ }$ & $\sqrt{ }$ & \\
\hline $\begin{array}{c}\text { Análise das estruturas } \\
\text { organizacionais da Creche } \\
\text { Futuro }\end{array}$ & & & $\sqrt{ }$ & $\sqrt{ }$ & $\sqrt{ }$ \\
\hline $\begin{array}{c}\text { Missão, objetivos da Creche } \\
\text { Futuro e projeto do } \\
\text { fundador }\end{array}$ & & $\sqrt{ }$ & $\sqrt{ }$ & $\sqrt{ }$ & \\
\hline $\begin{array}{c}\text { Análise da parceria com a } \\
\text { Prefeitura de Belo } \\
\text { Horizonte } \\
\end{array}$ & & & $\sqrt{ }$ & $\sqrt{ }$ & \\
\hline $\begin{array}{l}\text { Descrição das atividades } \\
\text { atuais da creche }\end{array}$ & & $\sqrt{ }$ & $\sqrt{ }$ & $\sqrt{ }$ & $\sqrt{ }$ \\
\hline $\begin{array}{c}\text { Análise dos recursos } \\
\text { financeiros da Creche } \\
\text { Futuro }\end{array}$ & & & $\sqrt{ }$ & $\sqrt{ }$ & \\
\hline $\begin{array}{c}\text { Análise dos processos de } \\
\text { comunicação da Creche } \\
\text { Futuro }\end{array}$ & & & $\sqrt{ }$ & $\sqrt{ }$ & $\sqrt{ }$ \\
\hline $\begin{array}{c}\text { Descrição das políticas de } \\
\text { Gestão de Pessoas }\end{array}$ & & $\sqrt{ }$ & $\sqrt{ }$ & $\sqrt{ }$ & $\sqrt{ }$ \\
\hline $\begin{array}{l}\text { Análise da dinâmica da } \\
\text { motivação de voluntários }\end{array}$ & & $\sqrt{ }$ & $\sqrt{ }$ & & \\
\hline
\end{tabular}

As duas primeiras etapas referem-se à análise da dimensão da obra social e

de elementos da cultura do movimento espírita, e foi calcado na análise de dados 
estatísticos, fornecidos pelas Federativas e por órgãos de pesquisa, no estudo do ethos da obra kardequiana e na revisão bibliográfica de estudos antropológicos, voltados à discussão do ethos espírita.

A análise da cultura e organização da Creche Futuro foi realizada com o resultado de diversas técnicas, principalmente o diário de campo (principal registro da observação participante); a análise de documentos e a descrição de atividades, sendo utilizados, muito pontualmente, alguns dados da história de vida para este fim.

A análise da parceria com a Prefeitura de Belo Horizonte - PBH foi realizada principalmente com base na análise de documentos e no diário de campo. Os arquivos da Creche contêm boa parte da correspondência trocada com a PBH, os documentos contratuais e os diversos certificados. Uma limitação desta análise consiste na ausência de entrevista com os prepostos do poder público, para que eles pudessem dar sua visão da parceria e a sua versão dos incidentes relatados.

O estudo da motivação dos voluntários tem por principal fonte as entrevistas transcritas, obtidas a partir da técnica de história de vida. A observação participante, entretanto, foi útil para o melhor entendimento do conteúdo das entrevistas.

6.6 Limitações do estudo.

A presente pesquisa sofre as limitações próprias de um estudo de caso, que envolve a questão dos cuidados com a generalização indevida dos resultados e a possibilidade de viés do pesquisador, mesmo associando diferentes técnicas de pesquisa e tomando cuidados com a objetividade de suas impressões.

O estudo de caso está sendo empregado como uma forma de identificar novas categorias de análise de cultura e motivação, capazes de aprimorar o poder 
compreensivo/explicativo de modelos teóricos existentes, entretanto, não há como se assegurar que as categorias analíticas novas sejam igualmente válidas e relevantes para todos os segmentos de organizações que compõem o Terceiro Setor. São necessários novos estudos, tanto para fins de comparação com o presente, quanto para fins de avaliação de sua aplicabilidade e abrangência no universo em foco.

A análise biográfica do ethos espírita brasileiro calcou-se apenas na obra de Allan Kardec, mas pode ser posteriormente ampliada com um estudo mais aprofundado do ethos espírita na obra mediúnica de Francisco Cândido Xavier e na verificação mais cuidadosa de sua adesão ou afastamento em relação ao pensamento kardequiano, como advoga Lewgoy (2001).

Os voluntários estudados são pessoas de meia-idade ou da terceira idade predominantemente. Essa é uma característica própria do território escolhido para estudo, o que limita a generalização dos resultados obtidos para outros segmentos, como o de jovens profissionais. 


\title{
7. OBRA SOCIAL ESPÍRITA: ETHOS E VISÃO DE MUNDO DO MOVIMENTO ESPÍRITA BRASILEIRO.
}

\begin{abstract}
Não faz isso, meu amigo seu Joãozinho Bem-Bem, que o desgraçado do velho está pedindo em nome de Nosso Senhor e da Virgem Maria! E o que vocês estão querendo fazer em casa dele é coisa que nem Deus não manda e nem o diabo não faz! - João Guimarães Rosa
\end{abstract}

O objeto da pesquisa é uma organização mantida por uma instituição espírita e com proposta associada ao pensamento espírita. A construção da identidade dos voluntários e o entendimento dos programas de gestão da organização, como já o foi proposto no desenvolvimento do referencial teórico da presente tese, exige o entendimento da influência do pensamento religioso (neste caso, espírita) nas atividades da creche.

O Instituto Brasileiro de Geografia e Estatística - IBGE, baseando-se nos dados do censo 2000, afirma que "os espíritas apresentam a maior média de anos de estudo", 9,6 em média. 2,34 milhões de pessoas afirmam-se espíritas no Brasil, segundo os dados do referido censo, o que representa cerca de 1,37\% da população brasileira. A grande maioria desses espíritas $(97,4 \%)$ é população urbana. Os três estados com maior número de habitantes que se declaram espíritas são: São Paulo com 760.882 espíritas (2,05\%); Rio de Janeiro com 397.365 espíritas (2,76\%) e Minas Gerais com 242.034 espíritas $(1,35 \%)\left(\right.$ INSTITUTO..., 2003) ${ }^{76}$.

Antes da apresentação da análise cultural, são relatados os dados de um levantamento bibliográfico e do resultado de uma enquete sobre a dimensão da obra social espírita brasileira.

\footnotetext{
${ }^{76}$ Dados obtidos no banco de dados agregados do SIDRA - Sistema IBGE de Recuperação Automática.
} 
7.1 A obra social espírita no Brasil

Qual é a dimensão da obra social espírita no Brasil? Que atividades são realizadas por ela?

A obra social espírita não pode ser considerada de dimensões inexpressivas, se for tomado, como referência, o Terceiro Setor brasileiro.

O Conselho Nacional de Assistência Social divulga um cadastro de entidades registradas. Em agosto de 2003, seu montante era de 15.311 organizações, que englobava as que tinham ou não o certificado de entidade com fins filantrópicos. Destas, 6545 possuem o certificado, sendo que 4685 se dedicam à assistência social, 735 à assistência à educação e 1125 à assistência à saúde. (CONSELHO..., 2003)

Fez-se um levantamento das organizações que usam o termo espírita ou kardecista em sua razão social e foi encontrado um montante de 460 , cerca de $3 \%$ do universo pesquisado. Há que se considerar que esse cadastro é federal e que a gestão das entidades espíritas não se notabiliza pela busca de recursos no Estado, como observou Giumbelli (1998).

$\mathrm{Na}$ presente pesquisa, procuraram-se números internos ao movimento espírita. Foram contatadas três instituições: a Federação Espírita Brasileira - FEB, a União Espírita Mineira e a União das Sociedades Espíritas do Estado de São Paulo.

A primeira iniciou um estudo nacional que não ficou pronto a tempo da redação do presente trabalho. A FEB estima em 10.000 o número de centros espíritas no Brasil, informação dada diretamente a esta pesquisa.

As duas outras federativas montaram um instrumento de pesquisa e solicitaram aos centros espíritas a elas filiados, mas tiveram baixa adesão de 
respondentes. Os dados sequer permitem a construção de uma amostra, razão pela qual serão apresentados sem qualquer pretensão de generalização.

A União das Sociedades Espíritas do Estado de São Paulo possui cerca de 1300 instituições filiadas, mas apenas 213 centros espíritas responderam à pesquisa. Estima-se que existam cerca de 3000 instituições espíritas no Estado de São Paulo, genericamente denominadas "centros espíritas",77. Esta diferença se dá pela existência de outras entidades federativas neste estado.

As atividades que realizam ficaram sintetizadas no gráfico que segue:

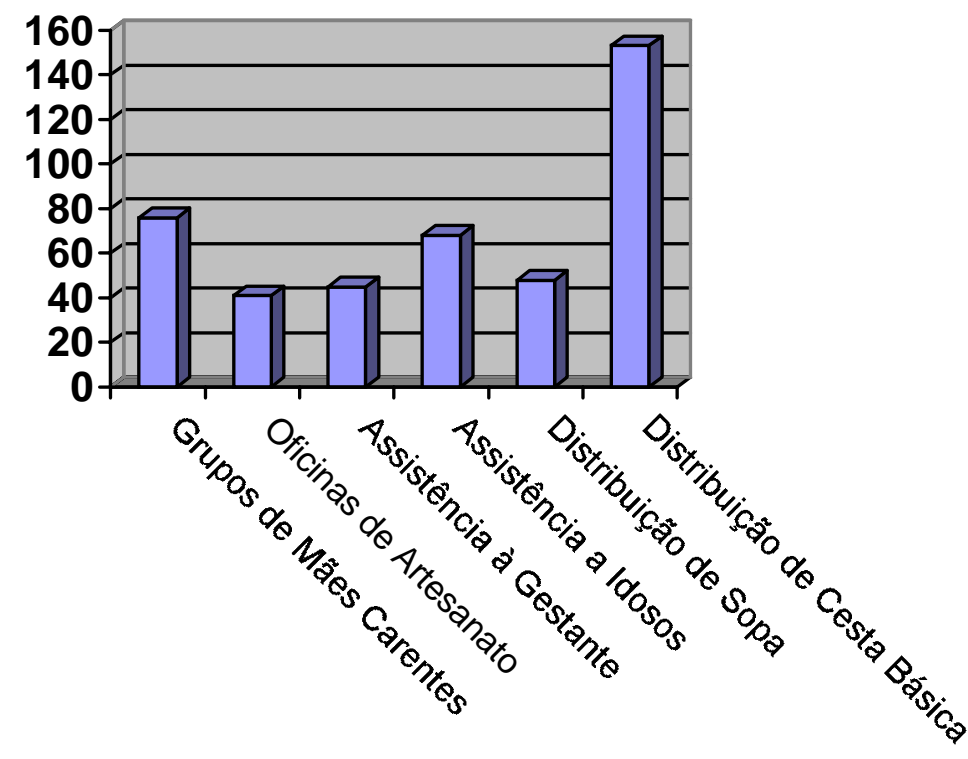

\section{$\square$ Programas Sociais}

Figura 14: Programas sociais das sociedades espíritas paulistas

O instrumento de pesquisa não cobria um grande número de atividades que se realizam nos centros espíritas como as visitas, a manutenção de escolas e de serviços de apoio a escolas, e a planilha enviada não continha os dados referentes à manutenção de organizações como asilos, creches, hospitais e albergues.

${ }^{77}$ FRANZOLIM (2003) 
Os centros afirmam contar com 2488 voluntários nesses serviços, ou seja, uma média de 11,5 voluntários por organização.

O programa mais incidente refere-se à distribuição de cestas básicas a famílias necessitadas. A pesquisa não nos permite inferir se os programas são associados ou se atendem a públicos independentes. De qualquer forma, o número de famílias assistidas por organização se encontra distribuído segundo a representação da figura que segue:

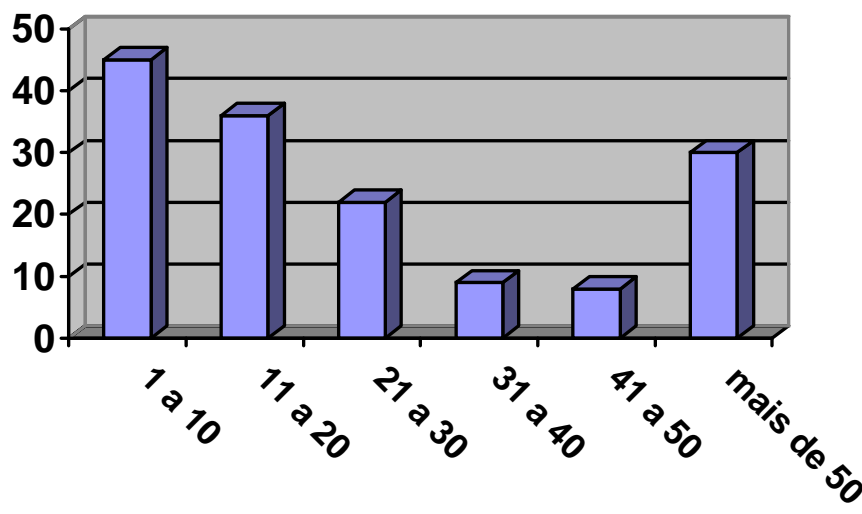

$\square$ Famílias assistidas por programa

Figura 15: Número de famílias assistidas por programa das sociedades espíritas paulistas

No Estado de Minas Gerais há 1108 centros espíritas filiados à União Espírita Mineira.(UNIÃO..., 2003) Foi igualmente realizada uma pesquisa das atividades sociais e, apesar de ter sido feita uma identificação mais detalhada das atividades sociais, os resultados da pesquisa não permitem sequer uma apresentação como os de São Paulo. Não houve o levantamento do número de centros espíritas respondentes. Os dados foram tabulados por região, mas algumas regiões não deram nenhum retorno. Os representantes da instituição entendem que, além da pouca preocupação em se levantarem dados institucionais, há alguma desconfiança com essa 
federativa, alguns centros fantasiam que os dados possam ser utilizados para algum tipo de controle (informação fornecida pelo representante dessa organização).

Os dados mais completos foram obtidos em espaço acadêmico e se referem ao Rio de Janeiro, mas dão boas indicações sobre a cultura e a gestão de organizações espíritas brasileiras.

Giumbelli (1998) dedicou-se à compreensão deste universo com base em pesquisa etnográfica em associação a dados quantitativos. Seu trabalho é bem denso e focalizado nas instituições do estado do Rio de Janeiro.

Ele corrobora a relevância do trabalho assistencial espírita, ao trazer o elogio de Betinho, publicado na Folha de São Paulo de 1993 e complementar com dados comparativos da pesquisa, na qual ele mostra que em uma pesquisa junto a 110 instituições espíritas fluminenses (Seu universo era composto de 864 instituições espíritas), 69,1\% declaram ter objetivos assistenciais, mas cerca de 93,6\% prestavam algum tipo de serviço.

As atividades assistenciais espíritas datam do século XIX, com a criação da Assistência aos Necessitados da Federação Espírita Brasileira, e mostra que, das obras existentes no Rio de Janeiro, "um terço delas foi fundado até 1950 e mais da metade até 1970”. O que se observa é que, no segmento religioso da instituição pesquisada, o surgimento, consolidação e sobrevivência das instituições assistenciais é bem anterior ao interesse pela administração e a sua continuidade é bastante significativa.

Com relação aos públicos atendidos no Rio de Janeiro, as obras sociais se voltam às crianças (84\%), famílias (48\%), idosos (37\%), adolescentes (26\%), gestantes (16\%) e população de rua (13\%). Esse dado não é exclusivo do movimento espírita, como se pode ver no trabalho de Fischer e Falconer (1999, p. 21). Estes autores 
encontraram resultados semelhantes, ao estudar os programas de atuação social de empresas brasileiras. Os principais públicos-alvo desta pesquisa foram crianças e adolescentes (47\%), adultos (30\%), famílias (16\%), terceira idade (15\%), seguidos por mulheres $(11 \%)$, gestantes $(10 \%)$, moradores de rua $(8 \%)$ e, finalmente, as minorias como portadores de HIV (6\%), dependentes químicos (4\%) e minorias étnicas (2\%).

Ele constatou em suas pesquisas que as instituições que trabalham com crianças são as mais antigas, comparativamente, mas que vêm se atualizando, especialmente no que tange à importância dos vínculos familiares, visitas às famílias, reuniões na instituição e material de orientação.

Uma vez dimensionado (ainda que precariamente) e apontadas algumas das principais atividades componentes da obra social espírita, discutir-se-á seu ethos e sua visão de mundo (GEERTZ, 1989) nas instituições brasileiras, com vistas à análise do contexto cultural e de alguns conflitos da organização.

7.2 Ethos e visão de homem na obra kardequiana

A fonte mais influente para o entendimento do movimento espírita brasileiro em geral $^{78}$ e do mineiro, especificamente, em nossos dias, ainda é a obra de Allan Kardec, em que pese a grande penetração e influência do trabalho do médium mineiro Francisco Cândido Xavier ${ }^{79}$. Focalizou-se a análise em Kardec, por se entender que a obra de Chico Xavier possui poucos pontos de litígio com o pensamento kardequiano ${ }^{80}$.

\footnotetext{
${ }^{78}$ Cf. CAVALCANTI, 1983, p. 22-26;

${ }^{79}$ MAIOR, 2003.

${ }^{80}$ Esta posição não é unânime, pois é questionada pelo estudo de LEWGOY (2001) que advoga uma tese alternativa. Ele, entretanto, baseou-se mais no mito Chico Xavier, construído por seus biógrafos, que em sua obra propriamente dita.
} 
O Espiritismo é um corpo de doutrina codificado inicialmente por Allan Kardec (pseudônimo do Prof. Leon Hippolite Denizard Rivail), na França da segunda metade do século XIX, que trata da "natureza, origem e destino dos espíritos, bem como de suas relações com o mundo corporal".(KARDEC, 1980, p. 50) Apesar de em suas origens ter se focalizado na observação de fenômenos mediúnicos, a interlocução com seus agentes possibilitou o desenvolvimento de uma visão de mundo complexa e lançou bases para a proposição de uma doutrina social espírita.

Foge ao objetivo deste trabalho fazer uma análise detalhada da cosmologia espírita, que já foi objeto de outros autores de dentro e de fora do universo espírita ${ }^{81}$. Deter-se-á na visão de homem, em seu ethos e em uma ação social espírita, pontos que são fundamentais para o entendimento da visão de mundo compartilhada pelos espíritas.

Em toda a obra kardequiana se encontra uma preocupação com a construção de uma ética racional, calcada nos princípios espíritas. O ser humano é apreendido como um ser espiritual, que encarnou no mundo em busca de evolução. A vida de relação, portanto, possui um significado transcendente e tem um sentido que só pode ser plenamente apreendido se for considerada a finalidade do homem, que é o seu aperfeiçoamento interior, o seu desenvolvimento intelectual e moral.

O pensamento kardequiano tem, em um de seus pilares, a existência de Deus e a defesa da justiça divina. Neste ponto, as diferenças sociais são explicadas por uma teoria complexa, que envolve os efeitos da ação de um homem imperfeito no mundo ${ }^{82}$, que tem liberdade de ação, mas se torna responsável por seus atos, vindo a sofrer na existência em que se encontra, ou nas existências futuras, as consequiências de seus

\footnotetext{
${ }^{81}$ Cf. GIUMBELLI (1998), CAVALCANTI (1983)

${ }^{82}$ KARDEC, 1978, p. 376.
} 
$\operatorname{atos}^{83}$. Com esta perspectiva existencial ampliada pela reencarnação e pela noção de evolução, o sofrimento que o indivíduo é incapaz de evitar não é visto como um mal em si, mas como uma experiência pela qual passa o espírito para a compreensão das leis universais e para a sua transformação.

Apesar de justificar o sofrimento em um plano divino ${ }^{84}$, o Espiritismo não propõe que, no plano dos homens, se justifiquem as grandes assimetrias sociais ${ }^{85}$, o que fez com que essa doutrina fosse identificada com o pensamento dos reformadores sociais da Europa do século XIX.

Enquanto ser-no-mundo, espírito encarnado, é um dever ético do espírita o seu autoconhecimento ${ }^{86}$, o seu autodesenvolvimento intelectual e moral ${ }^{87}$ e a sua ação humanitária, "sem distinção de raças, nem de crenças" (KARDEC, 1978a, p. 423), seja como membro da sociedade ou como membro de uma instituição.

Uma das consequiências do pensamento espírita para as transformações sociais é o entendimento de que as mudanças sociais estão condicionadas às transformações éticas dos indivíduos. Esta posição não se confunde, porém, com o individualismo à moda Smithiana, uma vez que o indivíduo em Kardec é considerado, quando evoluído, um "homem de bem”, que:

Encontra satisfação nos benefícios que espalha, nos serviços que presta, no fazer ditosos os outros, nas lágrimas que enxuga, nas consolações que prodigaliza aos aflitos. Seu primeiro impulso é para pensar nos outros antes de pensar em si, é para cuidar dos interesses dos outros antes do seu próprio interesse. O egoísta, ao contrário, calcula os proventos e as perdas decorrentes de toda ação generosa. (KARDEC, 1978b, p. 285)

Calcando-se na ética cristã, Kardec propõe como valores a benevolência para com todos, o respeito às convicções sinceras, a prática da caridade, a indulgência

\footnotetext{
${ }^{83}$ KARDEC, 1978a, p. 459.

${ }^{84}$ KARDEC, 1978b, p. 102.

${ }^{85}$ KARDEC, 1978a, p. 377.

${ }^{86}$ KARDEC, 1978a, p. 423-426.

${ }^{87}$ KARDEC, 1978a, p. 363.
} 
com as fraquezas do outro, a discrição com os defeitos alheios, a humildade, o desligamento dos bens materiais e das riquezas, o tratamento com bondade e benevolência aos que se tem sob mando, o cumprimento consciencioso dos deveres enquanto subordinado e o respeito aos direitos dos semelhantes. (KARDEC, 1978b, p. 284-287) Uma vez identificada a proposta ética espírita à proposta cristã (KARDEC, 1978b, p. 287), o escritor francês reconhece o caráter conflituoso desse projeto individual com os impulsos e desejos humanos, ao escrever:

Reconhece-se o verdadeiro espírita pela sua transformação moral e pelos esforços que emprega para domar suas inclinações más. (KARDEC, 1978b, p. 288)

Como conseqüência, há duas arenas privilegiadas para a ação social espírita: o cotidiano, uma vez que a proposta ética espírita propõe a transformação do homem na sociedade, e o centro espírita, que possui, pelo menos, um triplo caráter, o de espaço privilegiado para a comunicação com os espíritos, o de lugar dedicado, mas não exclusivo, de estudo da doutrina, e o de exercício da caridade em sua dupla dimensão ${ }^{88}$ : moral e material.

Na obra kardequiana, as recomendações referentes à gestão da obra social espírita são pontuais, especialmente se este conceito for circunscrito ao de assistência ou promoção social (caridade material).

Em "O Evangelho segundo o Espiritismo", encontram-se alguns textos que influenciaram a organização da obra social espírita brasileira. Kardec empregou uma máxima em referência a um dogma da igreja (fora da igreja não há salvação), que foi profundamente assimilada pelo movimento espírita brasileiro: fora da caridade não há salvação. Ele se funda no princípio da igualdade dos homens e da liberdade de

${ }^{88}$ KARDEC, 1978b, p. 226-229. 
consciência. Esta noção de caridade, entretanto, é ampla. Como já foi visto, ela não se circunscreve a atividades assistenciais.

Ao tratar do tema da desigualdade das riquezas, o espírito Fénelon defende o princípio de que as riquezas sejam usadas em benefício mais amplo, considerando um imperativo ético o emprego altruísta dos bens.

A beneficência é apenas um modo de empregar-se a riqueza; ela dá alívio à miséria presente; aplaca a fome, preserva o frio e proporciona abrigo ao que não o tem. Dever, porém, igualmente imperioso e meritório é o de prevenir a miséria. Tal, sobretudo, a missão das grandes fortunas, missão a ser cumprida mediante os trabalhos de todo gênero que com elas se podem executar. (KARDEC, 1978b, p. 275)

O emprego da riqueza em atividades beneficentes é uma constante nas diversas atividades espíritas brasileiras, como se verá nos estudos realizados por antropólogos, mas o tema da prevenção da miséria não foi igualmente desenvolvido nestas organizações, que se focalizaram em atividades de beneficência.

Há diversas mensagens transcritas por Kardec que incentivam o espírita a atuar em benefício de determinados públicos: criminosos (KARDEC, 1978b, p. 200201), leprosos e mendigos (KARDEC, 1978b, p.228), miseráveis (KARDEC, 1978b, p.233-234), órfãos (KARDEC, 1978b, p. 240), necessitados de diferentes opiniões, crenças e partidos (KARDEC, 1978b, p. 241) e famílias (KARDEC, 1978b, p.233-234).

De uma forma geral, condena-se a esmola que humilha, mas se incentiva a beneficência silenciosa, ações de reconhecimento como a “...de uma boa palavra, de uma carícia, de um sorriso amistoso." (KARDEC, 1978b, p. 240), visitação a instituições asilares e realização de trabalhos em benefício de terceiros, como a confecção de roupas. 
Um dos princípios apresentados por Kardec (que se baseia na crítica do orgulho) repousa na idéia de dar sem esperar retribuição. A realização das atividades é sempre sem promoção individual:

Silêncio. (...) Não o digas a ninguém. Falava assim Jesus. (KARDEC, 1978b, p. 223)

Um dos ditados espirituais que influenciou os leitores brasileiros de " $\mathrm{O}$ Evangelho Segundo o Espiritismo" é um relato do espírito Cárita, que conduz o leitor a uma visita a uma comunidade de miseráveis, para, a seguir, apresentar um grupo de senhoras que trabalham para auxiliar famílias durante o inverno europeu e que costuram, confeccionam roupas para socorrê-las. (KARDEC, 1978b, p.233-234)

O espírito São Vicente de Paulo entende que a obra que ele realizou enquanto encarnado é uma das que "mais hão de contribuir para o alívio dos semelhantes".

Como se pode observar, as obras mais conhecidas de Kardec tratam da ação social em uma perspectiva individual, quando muito, grupal. Kardec (1978c) escreve sobre a instituição espírita em um projeto publicado na Revue Spirite de 1868 e incorporado posteriormente no livro "Obras Póstumas". Neste trabalho, ele trata da obra assistencial como uma das "instituições acessórias", e propõe a organização de um dispensário (para consultas médicas gratuitas) "sob a direção de um médico diplomado", uma caixa de socorros e previdência, um asilo. Por fontes de recursos, ele sugere uma "caixa geral" e donativos.

A caixa geral seria mantida por associados de uma organização espírita, que fariam contribuições e participariam com cotas. Mas ele propõe que os recursos sejam capitalizados e transformados, com o tempo, em uma "renda perpétua", objeto de uma contabilidade rigorosa, cujas despesas seriam ordenadas pelos membros de uma 
comissão central e fiscalizadas por comissários designados para este fim, em assembléias gerais ou em congressos.

Proporcionalmente, com os recursos deste capital é que a comissão proverá às diversas despesas proveitosas ao desenvolvimento da Doutrina, sem que jamais faça dele aplicação pessoal, nem fonte de especulação para qualquer de seus membros. (KARDEC, 1978c, p. 374)

Em síntese, estes são os elementos do ethos kardequiano e de sua visão de

homem:

Quadro 9: Síntese do ethos e visão de mundo da obra kardequiana

\begin{tabular}{l|rl}
\hline \multicolumn{1}{c|}{ Elementos de Análise Cultural } & & \multicolumn{1}{c}{ Obra Kardequiana } \\
\hline Visão de Mundo & a) & $\begin{array}{l}\text { Calcada na existência de Deus e na Justiça } \\
\text { Divina } \\
\text { Noção ampliada de mundo e de sociedade } \\
\text { (mundo físico e mundo dos espíritos) }\end{array}$ \\
\hline Visão de Homem & a) & $\begin{array}{l}\text { Espírito encarnado, dotado de liberdade de } \\
\text { escolha, mas responsável por suas ações }\end{array}$ \\
\hline Ethos: Fundamentos & a) $\begin{array}{l}\text { Propõe a construção de uma ética racional } \\
\text { baseada em uma leitura dos princípios } \\
\text { valorativos cristãos }\end{array}$ \\
\hline Ethos: Valores & a) & Benevolência para com as outras pessoas \\
& b) Respeito às convicções sinceras \\
& c) & Humildade \\
& d) Cumprimento consciencioso dos deveres \\
& e) & Desligamento dos bens materiais \\
\hline Ethos: Imperativos & b) Autoconhecimento \\
& c) Autodesenvolvimento moral e intelectual \\
& Ação humanitária \\
\hline
\end{tabular}

Fonte: KARDEC, 1978a, KARDEC, 1978b, KARDEC, 1978c, KARDEC, 1980.

$7.3 \mathrm{O}$ ethos espírita, cultura e gestão em alguns estudos antropológicos

Há muitos estudos de cunho acadêmico sobre o movimento espírita brasileiro, nas áreas de História ${ }^{89}$, Comunicação Social, Literatura e Antropologia ${ }^{90}$. Nesta última área, os estudos permitem fazer uma abordagem do ethos espírita com base na observação de campo, realizada por cientistas sociais e antropólogos, que têm

\footnotetext{
${ }^{89}$ MACHADO, 1997, DAMAZIO, 1994, SILVA, 1997, ABREU, 1991.

${ }^{90}$ CAVALCANTI, 1983, GIUMBELLI, 1997, GIUMBELLI, 1998, LEWGOY, 1998, LEWGOY, 2001, STOLL, 1999.
} 
potencial para acrescentar contribuições à análise da literatura espírita, uma vez aceita a existência de um possível distanciamento entre o prescrito e o vivido.

Stoll (1999) tratou do tema da ética no movimento espírita e defende a existência de duas éticas no movimento espírita brasileiro: a ética da santidade, defendida por Francisco Cândido Xavier, e a ética da prosperidade, proposta por Luiz Antônio Gasparetto. Gasparetto, contudo, tem muito pouca ou nenhuma influência nos meios espíritas mineiros (e mesmo no Brasil), e este conflito fez com que ele passasse a não se identificar como espírita, o que demonstra sua clara distonia com o ethos espírita vigente no Brasil.

Cavalcanti (1983) realizou em sua dissertação de mestrado uma análise interna (baseada na visão dos espíritas) de duas organizações espíritas cariocas. Ela destaca, em seu trabalho, três instâncias da ação espírita: a mediunidade, o estudo e a caridade.

Ao analisar a caridade como instância, Cavalcanti entende que embora ela tenha a dupla dimensão de beneficência e de benevolência, os membros das organizações estudadas identificam sua prática privilegiadamente na relação entre espíritas e pobres, "uma relação de reciprocidade não só no plano moral como no social". (CAVALCANTI, 1983, p. 66)

Ao acompanhar o cotidiano da prática da caridade em diversas frentes de trabalho, Cavalcanti depreendeu, com base em inúmeros incidentes que documentou, que o ethos espírita relacionado à caridade envolve os seguintes valores: discrição, seriedade, controle, solicitude e paciência com os outros.

Em seu estudo, ela levantou algumas características importantes para o entendimento da influência da cultura do movimento, nos processos organizacionais de 
gestão. Essa pesquisadora observou que as tarefas são vistas como algo pessoal e que estão sujeitas a uma "regra de não interferência". Esse individualismo das tarefas teria levado Renshaw ${ }^{91}$ a postular personalismo, em seus estudos sobre reuniões espíritas de tratamento.

Ela denomina a hierarquia nas atividades espíritas como uma "hierarquia de potencial", uma vez que os cargos, e mesmo sua menção, são evitados nas relações interpessoais, e a escolha das pessoas para os cargos é feita com base "no mérito, na moral individual e nas próprias circunstâncias do trabalho". (CAVALCANTI, 1983, p. 57)

No grupo estudado por ela, os membros distinguem bem o espaço espírita do espaço empresarial. Como evidência disso, ela transcreveu o comentário de um dos membros que afirma: "não somos uma empresa, uma firma." (CAVALCANTI, 1983, p. 56)

Giumbelli (1998) realizou um estudo, no qual destaca o incentivo à prática da caridade como característico do Espiritismo Brasileiro (mas não do movimento espírita internacional), e o associa ao processo de inserção e consolidação da doutrina em nosso país. De alguma forma, a atividade assistencial concedeu respeitabilidade ao movimento espírita ante a sociedade e as instituições brasileiras. As lideranças desse movimento no Brasil, em diferentes planos, incentivam a prática da caridade.

Ele entende que há certo trânsito entre os conceitos de assistência espiritual e material, uma vez que, no ideário espírita, a assistência material e a espiritual são meios para o crescimento interior do assistido. A caridade é vista como uma "categoria condensadora" de disposições e traços rituais e estaria ligada à "percepção das

\footnotetext{
${ }^{91}$ Citado por CAVALCANTI, 1983.
} 
identidades" e à "legitimação de determinadas práticas no campo do Espiritismo". (GIUMBELLI, 1997, p. 281)

Lewgoy (1998) analisou um grupo de estudos espírita do Rio Grande do Sul em um trabalho de base etnográfica, com foco na linguagem. Em seu artigo, ele destaca o que denominou de "humildade retórica", que seria um protocolo ou código de humildade, assim como o emprego ostensivo do "plural de modéstia". Ele igualmente observou a formação de redes dentro do centro espírita e a intercalação entre a liderança carismática e a liderança burocrática. No ethos espírita, haveria uma restrição à personalização, que seria compensada pelo emprego do humor.

Além dos elementos citados, Lewgoy (1998, p. 12) destacou o respeito, a humildade, a subordinação e a elevação como pontos componentes do ethos espírita, que se tornam visíveis no momento da oração.

O quadro abaixo sintetiza o ethos espírita brasileiro na visão dos antropólogos:

Quadro 10: Ethos espírita brasileiro no estudo de alguns antropólogos

\begin{tabular}{c|c}
\hline Ethos & Fonte \\
\hline $\begin{array}{c}\text { Discrição, seriedade, controle, solicitude e paciência } \\
\text { para com os outros. (imperativos éticos na obra } \\
\text { social) }\end{array}$ & CAVALCANTI (1983) \\
\hline $\begin{array}{c}\text { Hierarquia de potencial: mérito, moral individual e } \\
\text { circunstâncias na escolha de cargos (imperativo } \\
\text { ético na obra social) }\end{array}$ & CAVALCANTI (1983) \\
\hline $\begin{array}{c}\text { Igualitarismo entre cooperadores e de gênero, mas } \\
\text { não entre cooperadores e freqüentadores (princípio } \\
\text { valorativo) }\end{array}$ & CAVALCANTI (1983) \\
\hline $\begin{array}{c}\text { Humildade retórica, restrições à personalização } \\
\text { (imperativo ético no estudo) }\end{array}$ & LEWGOY (1998) \\
\hline $\begin{array}{c}\text { Respeito, humildade, subordinação e elevação } \\
\text { (valores no estudo, especialmente na oração) }\end{array}$ & LEWGOY (2001) \\
\hline “...ser reverente a Deus, ser letrado, piedoso,obediente \\
e caridoso, assim como um bom cidadão, um \\
trabalhador disciplinado e um membro amoroso de \\
um núcleo familiar, combinando um ideal religioso \\
com um ideal civico"
\end{tabular}


Chamou a atenção de Giumbelli (1998) a associação entre as obras assistenciais e os serviços de evangelização e a justificativa dos entrevistados, que procuravam desvinculá-la do proselitismo religioso. Ele caracteriza a evangelização como um "proselitismo mínimo", próprio da visão de religião do pensamento espírita.

Neste ponto de seu trabalho, Giumbelli (1998, p. 153) defende a tese de que há certa "ambigüidade entre o religioso e o assistencial".

Outro dado que interessa na pesquisa deste cientista social diz respeito ao voluntariado. Ele distingue os centros espíritas, das obras assistenciais espíritas. Nessas duas instituições há uma diferença entre o número de voluntários dos centros espíritas (14 por assalariado) e o das obras sociais (2,8 voluntários por assalariado). Ele destaca que os assalariados das obras sociais são contratados para lidar com atividades-meio (administração e serviços de apoio), enquanto os voluntários se dedicam às atividadesfim (assistência social, atividades pedagógicas e ocupações ligadas à área de saúde).

Quanto aos recursos financeiros, os centros espíritas e obras sociais são mantidos principalmente por quadros de sócios. A seguir vêm os eventos beneficentes e doações, bazares, livrarias e cantinas. As obras sociais, entretanto, contam com doações de empresas (26\%) e subvenções governamentais (21\%). Não há referências na pesquisa aos valores das fontes no orçamento anual das instituições, há apenas a informação de que os centros espíritas têm por receitas as contribuições dos sócios, enquanto, nas obras sociais, as contribuições de sócios e os eventos concorrem, em importância, com os recursos vindos de órgãos governamentais.

Giumbelli estudou ainda a relação com o Estado. Ele cita o seguinte:

... segundo os informantes, os contatos de suas instituições percorrem predominantemente o universo interno ao Espiritismo (centros e organismos federativos), desprivilegiando o espaço da "comunidade local" e dos órgãos governamentais, e desprezando totalmente as empresas e os políticos. (GIUMBELLI, 1998, p. 157) 
Ao estudar este dado, ele observou que o isolamento não era tão drástico, que um grande número de centros espíritas "mantinha contatos regulares com agentes e instituições locais (escolas, associações de moradores, instituições filantrópicas) e que a maior parte destes contatos ocorria em função do desenvolvimento das atividades sociais".

Quanto ao Estado, ele destacou dois pontos: o repasse de recursos para as obras sociais e a obtenção de registros e títulos oficiais, como os de utilidade pública. Em seus dados, $45 \%$ dos centros espíritas e $76 \%$ das obras sociais espíritas foram reconhecidos como de utilidade pública. 


\title{
8. TRAJETÓRIA HISTÓRICA DA CRECHE FUTURO
}

\begin{abstract}
Que já houve um tempo em que eles conversavam, entre si e com os homens, é certo e indiscutível, pois que bem comprovado nos livros das fadas carochas. Mas, hoje-em-dia, agorinha mesmo, aqui, aí, ali e em toda a parte, poderão os bichos falar e serem entendidos, por você, por mim, por todo o mundo, por qualquer filho de Deus?! - João Guimarães Rosa
\end{abstract}

8.1 As origens

A Creche Futuro é uma divisão de uma organização religiosa espírita, construído a partir da determinação de sua diretoria em fundar uma "escola comunitária" (Ata da Reunião de Diretoria de 16 de dezembro de 1976). Após a obtenção da declaração de utilidade pública municipal pela mantenedora, decorrente das atividades de cunho assistencial que desenvolvia, iniciaram-se os esforços para a aquisição do terreno onde seria construído o prédio. Em 1980, a diretoria da mantenedora já havia avançado o projeto para a criação de um Lar Escola e de um Hospital Geriátrico, sob a idéia de permitir que o idoso pudesse interagir com a criança.

Uma das preocupações que mobilizou a diretoria fundadora é a da conservação da instituição sob a direção de pessoas espíritas. O diretor administrativo justificava essa preocupação com o fato de algumas organizações espíritas de cunho filantrópico já haverem perdido o caráter espírita em sua trajetória. $\mathrm{Na}$ reforma administrativa ocorrida no final da década de 70, os diretores modificaram a razão social da mantenedora, para enquadrarem-se nas exigências legais de obtenção do 
caráter de utilidade pública, mas o diretor, que seria um dos principais fundadores da Creche Futuro, fez o seguinte comentário, registrado em ata ${ }^{92}$ :

...o termo espírita deve ser mantido para que a instituição não venha a ser dirigida por pessoas não espíritas e para que as atividades espirituais não passem a ocupar um segundo plano.

Lê-se, em um dos periódicos da época, a seguinte explicação referente aos trabalhos assistenciais, que teria sido redigida pelo futuro diretor escolar da Creche Espírita Futuro:

É importante observar aqui que o trabalho não consiste em manter a família na dependência da Instituição, mas sim the dar meios de se fortalecer e "caminhar com os próprios pés" e, num futuro próximo ou remoto, de não mais necessitar de uma ajuda ostensiva. (Voluntário, 1982)

A Beneficência Portuguesa dispôs-se a doar um terreno que apresentava atrasos no recolhimento do Imposto Predial e Territorial Urbano. Os entendimentos com a prefeitura da cidade, entretanto, foram frustrados, uma vez que o prefeito se comprometeu a obter o perdão das dívidas, em decorrência da finalidade do uso, mas não o fez, alegando temer abrir um precedente legal para outras organizações que igualmente deviam ao erário público. $\mathrm{O}$ evento se encontra relatado em uma das atas da reunião da diretoria da mantenedora, datada de 20 de julho de 1980.

Três lotes foram doados pelo Hospital Espírita André Luiz no bairro Salgado Filho "para que fosse construída uma casa de benefício a crianças" e um quarto lote, adjacente aos doados, foi adquirido pela mantenedora para a construção de uma creche.

Para isso, foram constituídas três comissões ${ }^{93}$ : uma de construção, uma de recursos externos, para obtenção de recursos junto a outras organizações (como o Lions, maçonaria, órgãos públicos e empresas comerciais), e uma de "arrecadação" para obtenção de recursos em meio aos membros da mantenedora. A construção da Creche

\footnotetext{
${ }^{92}$ Ata da reunião de diretoria de 03 de fevereiro de 1977.

${ }^{93}$ Ata da reunião do Conselho Eleitor e Consultivo de 12 de outubro de 1980.
} 
Futuro mobilizou bastante os membros da mantenedora, que realizaram diversas campanhas, atividades artísticas (show de yoga no Palácio das Artes, por exemplo) e diversas outras atividades de menor porte (venda de livros, adesivos, cartões de Natal e outras iniciativas pontuais), para angariar os recursos necessários à construção. Montouse uma estrutura contábil própria para a arrecadação, encaminhamento e prestação de contas dos recursos obtidos com esta finalidade. Os responsáveis faziam relatórios mensais para os envolvidos.

Houve impactos desse crescimento na estrutura organizacional da mantenedora, porque esta havia desenvolvido um sistema misto de estrutura divisional e funcional, para incorporar a Creche Futuro e outra instituição terceira, que foi um "centro comunitário" na região de Citrolândia, município de Betim. Já havia sido criado um conselho eleitor e consultivo como fórum deliberativo para a diretoria ${ }^{94}$ e, posteriormente, uma assessoria de planejamento ${ }^{95}$.

Os prédios que compõem a Creche Futuro e alguns de seus espaços foram sendo identificados com os nomes de pessoas já falecidas, em homenagem por suas obras, que marcaram a vida da mantenedora, como os nomes de dois dirigentes. $\mathrm{O}$ núcleo de costura recebeu o nome de uma voluntária do grupo de yoga, que, apesar de estar com câncer, participou das demonstrações no Palácio das Artes vindo a falecer antes da construção. Ela encarna o espírito de dedicação e de sacrifício, que são valores de destaque para os fundadores da organização, assim como a idéia de que a morte é uma continuidade da vida, princípio fundamental no Espiritismo.

Essa instituição foi criada sob grande influência de uma outra instituição espírita, a Mansão do Caminho, que funciona em Salvador-BA. Em abril de 1983 já se

\footnotetext{
${ }^{94}$ Ata da reunião de diretoria de 03 de fevereiro de 1977.

${ }^{95}$ Ata da reunião do Conselho Eleitor e Consultivo de 25 de abril de 1982.
} 
iniciou o funcionamento da atividade de evangelização infantil nas instalações semiconcluídas da Creche Futuro, para atender à comunidade ao redor. Em setembro de 1983, o Conselho Eleitor e Consultivo convidou um médium fluminense para participar da reunião, apresentar seus conhecimentos sobre organizações com o mesmo objetivo e relatar suas percepções do ambiente espiritual da organização em questão. Nessa reunião ${ }^{96}$, esse médium salientou o papel de destaque de um coordenador da Mansão, que, possivelmente, influenciou a criação do cargo de superintendente para a Creche Futuro, ao lado de um diretor escolar. Ele defendeu, igualmente, a idéia de que as pessoas que lidam com a criança não necessitam, imprescindivelmente, de "títulos acadêmicos", mas de uma mentalidade espírita.

8.2 A preocupação inicial com recursos para a manutenção.

A reunião de diretoria da mantenedora de janeiro de 1982, já se preocupava com a obtenção de recursos financeiros para o funcionamento da Creche. A idéia inicial tinha por base a associação mantenedora da Mansão do Caminho, na Bahia, que possuía um bazar, uma flora e uma livraria no centro da capital baiana. Como já havia a frustração com o poder público, por ocasião da doação dos lotes da Beneficência Portuguesa, naquele momento a posição da diretoria foi contrária, a se firmar qualquer convênio com um órgão público. A expressão empregada foi "evitar construir castelos de areia".

Em abril de 1982, criou-se uma assessoria de planejamento na mantenedora. Ela parece ter se desincumbido de sua função, ao focalizar a obtenção de recursos financeiros para a consecução da obra em curso e acompanhar o ritmo das construções.

\footnotetext{
${ }^{96}$ Ata da reunião do Conselho Eleitor e Consultivo de 18 de setembro de 1983.
} 
Não se encontrou, porém, qualquer documentação que se assemelhasse a um planejamento estratégico da mantenedora, e os documentos referentes a planejamento encontrados na Creche Futuro, mais de 20 anos depois, ainda tinham um caráter de planejamento de obras e de reformas, mas não apresentavam qualquer reflexão referente ao caráter administrativo, pedagógico ou ao projeto social da organização.

Um projeto que talvez estivesse associado à idéia original de obtenção de recursos via prestação de serviços ou outra atividade lucrativa foi a construção de uma marcenaria no âmbito da Associação.Havia um grupo de jovens da mantenedora que tinham uma atividade de construção de brinquedos de madeira para doação, sob a forma de presente, nas cestas de Natal. Um dos membros do conselho diretor era um instrutor do SENAI que vislumbrou a possibilidade de adquirir a maquinaria usada de marcenaria por um preço acessível. Uma vez aceita sua idéia, ele fez uma campanha particular e levantou os recursos. A diretoria decidiu construir o galpão em um dos terrenos da Creche Futuro $^{97}$. O funcionamento iniciou-se no ano seguinte. Com o passar dos anos, a marcenaria teve um papel ativo nos objetivos do grupo de jovens, isto é, eles fabricavam brinquedos de madeira para distribuição às crianças, faziam algum mobiliário e utensílios para a mantenedora e suas duas unidades sociais, além de caixas para um apiário. Fabricaram, também, alguns objetos que eram vendidos ao público que freqüentava os bazares da mantenedora. Houve um projeto de qualificação de jovens assistidos, interessados em marcenaria, mas não há registro desta iniciativa, que possivelmente se perdeu pela falta de gestão e comprometimento institucional. Essa marcenaria, mantida essencialmente por trabalho voluntário, funcionou com esse papel secundário, do ponto de vista da obtenção de recursos, até o início deste século, quando

\footnotetext{
${ }^{97}$ Ata da reunião do Conselho Eleitor e Consultivo de 30 de maio de 1982.
} 
foi proibida de atuar naquela unidade, em decorrência da lei de uso de solo do município de Belo Horizonte. Anos após a proibição, o maquinário foi doado a um outro centro espírita em que ele poderia efetivamente ser empregado para a qualificação de pessoas de baixa renda, nas imediações da região da lagoa da Pampulha. Essa situação frustrante ilustra uma das propostas analíticas deste caso, a da emergência de territórios de influência dentro de uma organização de Terceiro Setor com certo porte e número de participantes, em decorrência de diversos fatores, tais como, a fragilidade da função planejamento das atividades que vão sendo constituídas; o caráter pessoal dos projetos, a existência de lideranças de cunho carismático, assim como a fragilidade de órgãos administrativos.

Outras propostas que surgiram nas reuniões foram a construção de uma loja de produtos naturais, que não foi efetivada porque se decidiu que a margem de lucro seria muito pequena ${ }^{98}$; a exploração da atividade de uma cantina em uma unidade de quadras de aluguel $^{99}$, para a qual se optou pelo arrendamento e a montagem de um apiário $^{100}$, que chegou a funcionar durante algum tempo sob a mesma feição da marcenaria: um trabalho eminentemente voluntário no qual até mesmo a área em que foram colocadas as colméias era cedida. Esta última iniciativa funcionou durante algum tempo, mas não há registros posteriores nas atas sobre o seu impacto financeiro. Em uma reunião posterior $^{101}$, discutiu-se a construção de uma lavanderia e a aquisição de máquinas profissionais, para lavar os uniformes das crianças. Sugeriu-se que se aproveitasse a estrutura instalada para prestar serviços de lavanderia, com a finalidade de se obterem recursos financeiros. A proposta não foi aprovada nem reprovada naquela

\footnotetext{
${ }^{98}$ Ata da reunião do Conselho Eleitor e Consultivo de 30 de maio de 1982.

${ }^{99}$ Ata da reunião do Conselho Eleitor e Consultivo de 10 de abril de 1983.

${ }^{100}$ Ata da reunião do Conselho Eleitor e Consultivo de 10 de abril de 1983.

${ }^{101}$ Ata da reunião do Conselho Eleitor e Consultivo de 23 de novembro de 1986.
} 
reunião. A lavanderia foi construída, mas não foi transformada em empresa. Quando a presente pesquisa iniciou suas ações de descrição de atividades, a lavanderia estava desativada, em decorrência do racionamento de energia elétrica.

Outra frente de obtenção de recursos de manutenção foram diversas campanhas e doações para a creche. A direção possivelmente acreditava que conseguiria manter as crianças com doações dos freqüentadores e dos trabalhadores da mantenedora. Uma das iniciativas foi a campanha "adote uma criança" realizada no âmbito da mantenedora, mas com vistas à participação externa. Essa campanha baseavase na doação de uma quantia estimada para custear os cuidados mensais com uma criança na creche. Os resultados não permitiram a auto-suficiência do projeto, e outro fenômeno não esperado tornou essa fonte inviável: passado o calor da publicidade, um número significativo de doadores deixava de contribuir.

O que será visto posteriormente é que essas iniciativas não foram bem sucedidas, o que será fundamental para que a mantenedora venha a firmar um convênio que lhe permita manter a Creche Futuro com a Prefeitura de Belo Horizonte.

\subsection{A estrutura organizacional inicial da Creche Futuro}

Em setembro de 1985 era levada para discussão e debate uma estrutura organizacional, com um organograma "do tipo estado maior ${ }^{102 ", ~ d e s c r i c ̧ a ̃ o ~ d e ~ r o t i n a s ~ e ~}$ atribuições, feita após uma seqüência de reuniões de trabalhadores da mantenedora, "de formação profissional superior, em num pequeno curso de 30 a 40 horas, elaboraram as normas e procedimentos dos setores da Creche Futuro ${ }^{103}$ ".

\footnotetext{
${ }^{102}$ Este foi o termo empregado pelo diretor administrativo.

${ }^{103}$ Ata da reunião do Conselho Eleitor e Consultivo de 09 de setembro de 1985.
} 
Essa estrutura era composta de um órgão colegiado, construído com representantes dos diversos segmentos supramencionados e mais três escolhidos pelo conselho da mantenedora, formando um total de nove elementos. Subordinado a ele, a autoridade maior da organização seria um superintendente, responsável pelas tarefas do dia-a-dia, mas "sem se preocupar com o serviço burocrático". Este contaria com o apoio de duas assessorias voltadas "ao controle da qualidade e aos padrões de desempenho da Creche Futuro", e ainda uma assessoria de avaliação e uma assessoria espiritual.

A creche funcionaria com a criança sendo recebida pela manhã e entregue às famílias no final da tarde, "não rompendo assim os laços familiares". Elas tomariam banho antes de serem entregues aos pais. Estes participariam de um encontro mensal com os serviços de psicologia, assistência social e médico-odontológica. A creche contaria, também, com os serviços de professores e supervisores espíritas contratados e voluntários. Citou-se o projeto de um acompanhamento escolar.

A primeira estrutura contaria com três setores pelos quais eram distribuídos os serviços: 


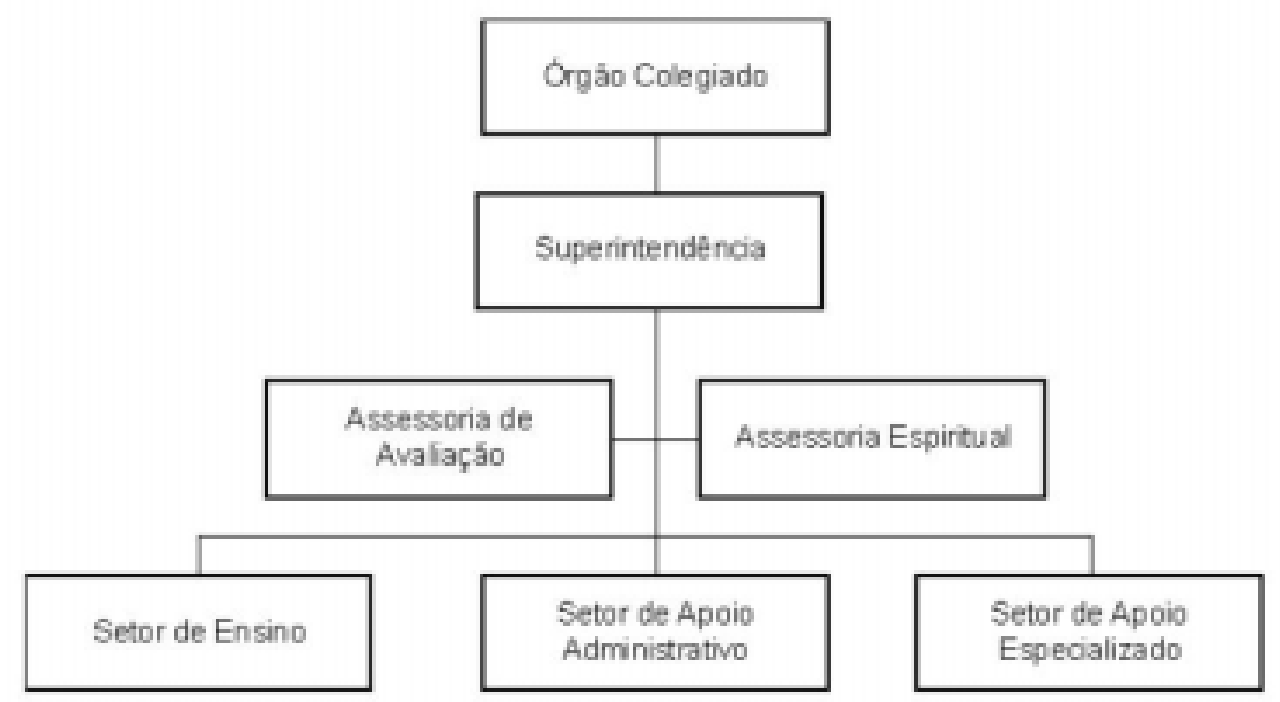

Figura 16: Primeira estrutura organizacional da Creche Futuro

O Setor de Ensino continha os serviços de pedagogia, de psicologia, de assistência social e de educação física. O Setor de Apoio Administrativo congregava o serviço de nutrição e dietética, o serviço de manutenção e o almoxarifado. O setor de apoio especializado seria responsável pelos serviços médico, odontológico, de admissão, de biblioteca e o bazar permanente.

Foi nomeado um chefe do Setor de Ensino, mas não houve nomeação de chefes para os outros serviços, o que, do ponto de vista organizacional, contribuiu para a fragmentação dos serviços da Creche Futuro.

O superintendente da época, em entrevista, afirmou que, na verdade, não houve como se desvencilhar das atividades burocráticas, devido à necessidade de rascunhar os balancetes de despesas e receitas para o contador voluntário. Como ele já houvesse feito este tipo de trabalho em sua carreira profissional, considerou que suas 
atribuições ficaram pouco delimitadas, e parece ter optado por um trabalho que, além de necessário à organização, concretizava seu papel na organização.

Essa estrutura teve vida curta e sequer chegou a funcionar efetivamente, especialmente se considerados os serviços propostos no nível inferior aos setores. A ata da reunião do Conselho Eleitor e Consultivo da mantenedora justifica a mudança organizacional da seguinte forma:

Não correspondeu às expectativas por se tratar de uma "empresa" religiosa, que não visa a lucros e onde os encarregados pelos diversos setores e voluntários gerais são amadores e ali estão de boa-vontade para trabalhar. ${ }^{104}$

Observam-se, neste ponto, as dificuldades de se colocar atividades do dia-adia nas mãos de voluntários que possuem vida escolar e/ou profissional ativa, além das obrigações com suas famílias. Como houve exceções, supõe-se que este não deve ser o único fator de desagregação de equipes de voluntários. Boa parte da equipe designada era de jovens universitários, ligados ao grupo de jovens da mantenedora, cuja dirigente era uma antiga diretora, que, como se comentará posteriormente, tinha uma proposta de projeto para a organização da creche. Pode-se dizer que a participação desses jovens no projeto se deu "por procuração", ou seja, o sonho dos fundadores os contagiou pela proximidade, por sua ascendência, mas não era o seu próprio sonho. O organograma da creche ficou da seguinte forma:

${ }^{104}$ Ata do Conselho Eleitor e Consultivo, p. 61. 


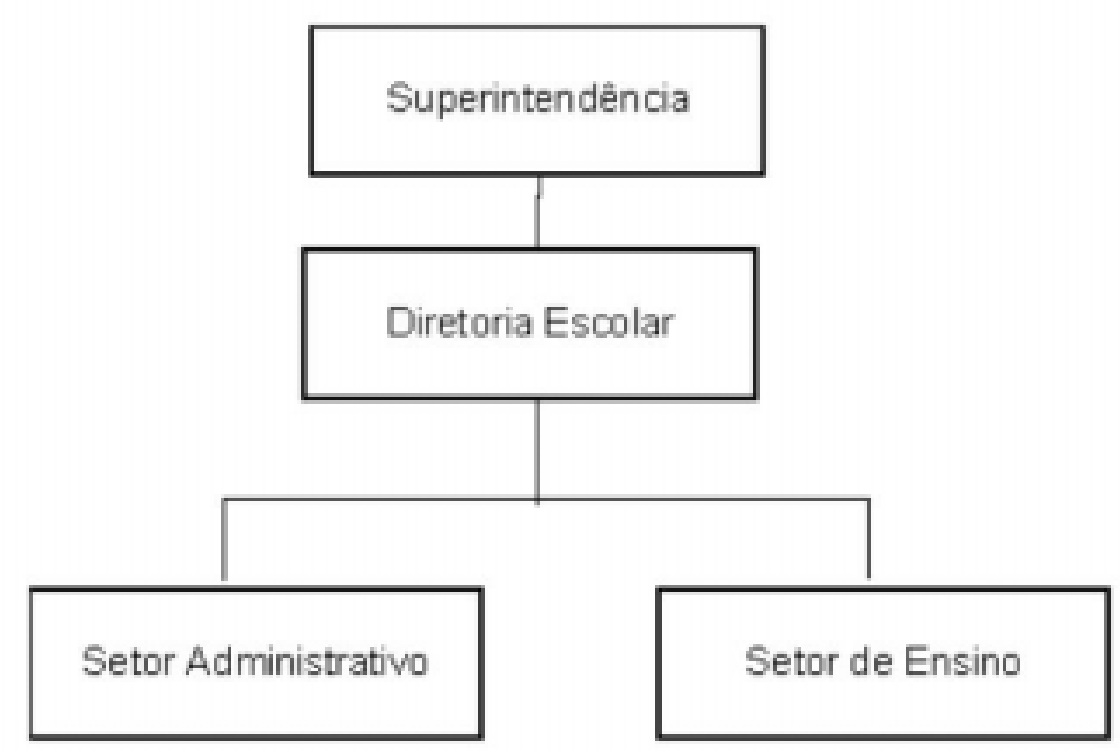

Figura 17: Reforma da estrutura organizacional da Creche Futuro em 1986

Não há menção no referido documento sobre a manutenção ou não do órgão colegiado ou sobre as assessorias, que parecem ter sido extintas. Os chamados serviços especializados que sobreviveram ao primeiro ano foram submetidos à chefia do Setor Administrativo. Este organograma não contempla os demais serviços assistenciais que já funcionavam na mesma estrutura da Creche Futuro, mas subordinados a uma estrutura da mantenedora. Apesar da concepção de articulação, o modelo de gestão mantinha uma segregação em nível de direção entre as atividades de creche e as demais atividades assistenciais.

8.4 A crise $87-88$

O primeiro projeto organizacional de creche evitou que uma outra proposta de gestão viesse à luz. A instituição de uma equipe para desenho da organização foi 
também uma manobra na qual o diretor administrativo da mantenedora se antecipou à diretora anterior a ele, que havia trabalhado intensamente na captação de recursos e que tinha outra idéia de como se deveria organizar a creche. Não há registros de suas concepções nos documentos obtidos.

Essa diretora se tornou uma das lideranças carismáticas que acompanharia o cotidiano da organização como chefe do setor administrativo e, de certa forma, influenciaria grandemente a gestão da Creche Futuro, por respeitar as decisões arbitradas, mas sem abrir mão das suas convicções.

Posteriormente, houve um desentendimento quanto a diretrizes e valores entre essa dirigente e a diretoria. Este desentendimento se tornou institucional, pois foi evoluindo e culminou com o afastamento dessa diretora, primeiro das suas atividades na mantenedora e, depois, da Creche Futuro. Após sua saída, ela fundou uma outra associação espírita com obra social ainda maior, em outra periferia de Belo Horizonte e levou consigo muitos voluntários ligados à Creche Futuro.

Durante o trabalho de observação de campo e nas entrevistas com voluntários mais antigos, constatou-se que o assunto era sempre evitado, visto que este fato gerou um grande sofrimento para muitos dos envolvidos. Um dos voluntários chegou a descrever sintomas de somatização devido a esse conflito, como se lê abaixo:

Estávamos ainda montando a Creche Futuro e a cobrança era muita de determinados companheiros que às vezes ficavam de fora e não entendiam as dificuldades nossas. Tanto assim que com um ano e pouco de trabalho nosso, nós fomos visitados por um problema de ordem física mas ligado ao psiquismo, eu diria. (Voluntário entrevistado)

Outro voluntário relata seu afastamento nesse período:

Entrevistador - Alguma vez nesse trabalho você sentiu vontade de se afastar?

Voluntário Sim.

Entrevistador - Por causa de pessoas? 
Voluntário - Porque houve muitas lágrimas, né? Tem uns que querem mandar mais do que outros. Como em todo lugar, né." (Voluntário entrevistado)

Referindo-se a esse assunto em uma das reuniões com a diretoria, os diretores disseram que não havia muito que dizer, e um dos diretores atuais comentou, espontaneamente, que havia assumido a direção das atividades que aquela diretora realizava na creche e, ao conversar com os voluntários, achou estranho que eles entendessem o seu compromisso como um acordo pessoal com o líder, e não como um compromisso institucional.

Essa crise aponta um padrão recorrente nos processos de liderança da Creche Futuro e de sua mantenedora semelhante aos observados pelos antropólogos em suas respectivas organizações. De uma forma geral, as equipes de trabalho voluntário se agrupam em torno de líderes mais ou menos carismáticos ${ }^{105}$, que possuem uma grande influência sobre os processos decisórios. Ele transforma o espaço do trabalho voluntário em um espaço de afetos, onde há um vínculo afetivo importante com o líder.

Esse pressuposto básico da creche (seria um pressuposto básico das organizações de Terceiro Setor?) esvazia os fóruns de decisão, dificulta o questionamento racional de propostas, transforma, com facilidade, uma diferença de entendimento em uma diferença pessoal e gera fenômenos de grupo internos, para os quais um dos manejos adotado pela diretoria foi a territorialização de influências, sobre a qual se discorrerá posteriormente.

Por outro lado, a relação afetiva entre líder e subordinado se torna um vínculo não -financeiro importante do subordinado para com o seu trabalho. Esse tema voltará a ser apresentado na análise das entrevistas com os voluntários.

\footnotetext{
${ }^{105}$ No sentido que atribui FREITAS (2000. p. 132) ao termo.
} 
8.5 A filosofia de base e as diretrizes dos fundadores

Alguns pressupostos desses diretores, que ocupam o papel de fundadores, no sentido que Schein (1992) lhe aplica, envolvem a visão de ação social a ser realizada pela mantenedora.

O diretor que coordenou todo o processo de construção e concepção administrativa da organização publicou a concepção e diretrizes da creche, na qual expõe que o seu papel social é o de combater a "desagregação da célula familiar" (FUNDADOR, 1983). Ele entende que essa desagregação é a gênese de uma espiral descendente em que se insere a criança e conduz o jovem ao tóxico, e a jovem à prostituição, ambos a comportamentos anti-sociais e ao crime. Ele tinha uma visão de ação social co-responsável com o papel do Estado, pelo menos dez anos avançada para a sua época, na qual ele afirma que:

Nossa obra foi idealizada para fugir aos paliativos paternalistas, destinandose a atender a um segmento significativo da população local, através do esforço comunitário que emana de um grupo da própria sociedade que se sente co-responsável pelo problema. Assim, em vez de nos omitirmos, transferindo para o governo a solução global da questão, entendemos que esse é parte da própria comunidade, provisoriamente investida de responsabilidades maiores. (FUNDADOR, 1983)

Essa visão se opunha claramente à de assistencialismo paternalista, considerado um estágio anterior ao que se propunha fazer, como se pode constatar em outro documento:

...Gradativamente, ao longo dos anos, fomos nos afastando de um trabalho no qual prevalecia a boa vontade e o sentimento, mas que era norteado pelo paternalismo, para alcançarmos um estágio de trabalho comunitário, em que à boa vontade e ao sentimento, somamos também o raciocínio. (FUNDADOR, 1983)

Ele propõe os três princípios abaixo, orientadores para o serviço de assistência à infância, destinado a "eliminar, tanto quanto possível, o sentimento de 
orfandade", "procurar oferecer família à criança que não a possua" e "não separar a criança de sua família, quando essa existir”. (FUNDADOR, 1983)

Nesse mesmo documento propõe-se que o funcionamento da creche seja diurno, ficando sob cuidados multiprofissionais (assistentes sociais, psicólogos, etc.) e de coordenação administrativa voluntária.

Uma diretriz importante é a de não se fazer uma escola primária, segundo ele: "para não sobrepormos esforços àqueles já desenvolvidos na região pelo poder público". Essa idéia modificou o projeto inicial de se fazer a "escola comunitária" e transformou-o em uma creche.

O fundador idealizou igualmente algum tipo de acompanhamento das crianças, posterior à sua inclusão no sistema de ensino. Um esquema de acompanhamento escolar com professores e voluntários, encaminhamento a cursos profissionalizantes do SENAI ou entidades similares para as crianças que viessem a concluir o primeiro grau. Havia a preocupação com que as famílias saíssem da posição de espectadoras, "tornando-se participantes" e com a escolha preferencial de famílias mais numerosas com menor renda familiar, que seriam acompanhadas periodicamente para se verificar se elas estariam "complementando no lar o esforço da instituição". (FUNDADOR, 1983)

Outra frente de atuação seria a de educação das mães, por meio de cursos rápidos de atividades domésticas (como corte e costura, bordado, culinária, crochê e outras atividades cotidianas), que permitiriam que elas fossem "mais qualificadas no mercado de trabalho" e, por extensão, passassem a "contribuir na formação da renda "per capita" familiar, para complementar o esforço dos pais. Esse projeto preocupava-se em reduzir o afastamento entre mãe e filhos, em decorrência das obrigações do trabalho. 
Esse diretor associou a atividade de distribuição de cestas de alimentos já existente também aos pais das crianças assistidas pela Creche Futuro.

Como se pode ver, o fundador procurou associar as diferentes atividades assistenciais em curso, visando à promoção social das famílias atendidas institucionalmente, mas criou uma estrutura organizacional insuficiente para a consecução dos objetivos. Ela contemplava principalmente as atividades de creche, esquecendo-se da inserção organizacional das outras atividades assistenciais.

Com o passar do tempo, essa visão não foi mantida e trabalhada com os novos membros que viriam futuramente, o que se constatou na análise dos processos de gestão (não há uma espécie de treinamento introdutório, ou algo semelhante) e nas entrevistas realizadas com os voluntários (cf. item 10.3)

Outro problema que se observa apenas a posteriori é o alcance de adesão dessas premissas, principalmente a de promoção social e a de articulação das diversas tarefas, entre colaboradores e coordenadores do trabalho.

Um terceiro problema, calcado em uma premissa muito festejada, mas pouco discutida, a da manutenção da integridade da família, irá gerar uma das crises pelas quais passou a organização, no final dos anos 80, quando já havia um número significativo de crianças e famílias sob sua responsabilidade.

8.6 O início das atividades de creche

O principal documento que trata do início das atividades da creche é o livro de relatórios das supervisoras. Este documento foi criado para se dar uma continuidade ao trabalho das supervisoras voluntárias, que se revezavam em turnos de quatro horas. Esse livro contém notas sobre o controle de frequiência dos voluntários e crianças, sobre 
os medicamentos ministrados às crianças, o registro de anormalidades (como a realização de uma conferência, por exemplo) e as doações feitas. Não há, porém, muitos dados sobre a dinâmica da organização.

A creche recebeu suas primeiras oito crianças em 21 de outubro de 1985, estando presentes nove pessoas, dentre elas o superintendente.

Em agosto de 1986, encontra-se o registro da creche na Secretaria de Estado de Educação e, no ano seguinte, já havia 45 alunos efetivos, segundo o registro geral do estabelecimento de ensino. Este número vai crescendo a cada semestre e no início de 89 ocorre uma crise que exige mudanças de rumo na gestão.

\subsection{A crise de 89}

O livro de atas de reunião do órgão colegiado da Creche Futuro teve seu primeiro registro em 1989, quatro anos após o início das atividades da creche. Há uma crise instaurada, que tem, por pano de fundo, os problemas financeiros e os conflitos entre grupos de colaboradores e dirigentes.

Essa crise está associada a um sistema frágil de esforços financeiros, baseado em campanhas. A direção da mantenedora não obteve sucesso na criação de fontes de recursos financeiros que permitissem o funcionamento da estrutura física $\mathrm{e}$ administrativa necessária à manutenção de cerca de 80 crianças. Aos poucos, foi-se verificando que o trabalho voluntário que mantinha a organização não continha a demanda de contratação de profissionais.

A mantenedora tinha os recursos de doação de um quadro de sócios, os da venda de livros e os de esforços de campanhas, como um bazar beneficente e a promoção de eventos. Como ela apresenta o duplo caráter de instituição religiosa e 
associação de filantropia, os recursos destinados às atividades de caráter religioso e a outras atividades de cunho filantrópico começaram a ser empregados para o sustento da creche.

Isso levou a direção da mantenedora a publicar uma resolução e desencadear uma seqüência de reuniões com as lideranças da creche para solucionar os impasses. A resolução, basicamente, sintetiza-se no texto abaixo:

i. "a finalidade básica de qualquer tarefa da mantenedora, inclusive a Creche Futuro, é a reforma íntima de seus colaboradores, que deve prevalecer sobre o aspecto meramente filantrópico;"

ii. "que nas atividades da Instituição como um todo deverão ser priorizados aquelas de natureza espírita e não meramente as assistenciais"

iii. "que a manutenção da Creche Futuro, como serviço assistencial, não pode sufocar as demais atividades da casa, quer pelo deslocamento constante de recursos financeiros, quer pela absorção de quase todos os seus recursos humanos"

iv. "que em vista disto, a Creche Futuro só pode ser operada sem prejuízo das demais divisões da mantenedora nas quais prevaleçam as atividades de caráter espiritual, bem como, dentro de uma realidade administrativa que assegure sua viabilidade econômico - financeira" (MANTENEDORA, 1989)

Uma das medidas empreendidas no saneamento financeiro foi a mudança de nome de Creche Escola Futuro para Creche Espírita Futuro, o que ocorreu em abril de 89. Com esta mudança, a creche futuro deixou de ser considerada escola e passou a funcionar como creche, o que fez com que as monitoras não tivessem direito ao piso da categoria de professor, gerando economia na folha de pagamentos, que era a maior despesa operacional da creche.

A outra crise, a de identidade, teve por motivo o impasse entre os colaboradores da organização por causa da falta de clareza dos critérios de exclusão e inclusão de crianças. A população-alvo da região atendida tinha por característica a família formada por mãe e filhos, principalmente.

Os estudos de Pereira (1990) com mães subproletárias de região vizinha (o bairro "Cabana") mostraram que o núcleo familiar é basicamente constituído da mulher 
com sua prole, sendo o homem um companheiro temporário, e a figura masculina, uma figura deteriorada na percepção das mulheres ( $\mathrm{O}$ homem é uma pessoa em quem não se pode confiar, e o "homem bom" é o que consegue ocupar o lugar de provedor, que "põe comida" em casa). Elas se submetem a maus tratos e exigências do companheiro, desde que este a ajude na "criação dos filhos", mas o mandam embora quando ele se torna mais um peso e uma ameaça, o que costuma estar associado ao consumo de alcoólicos e ao desemprego crônico. Seguramente, tais estudos eram desconhecidos pelos idealizadores do trabalho, que se basearam na experiência de um modelo de família mais aos moldes dos migrantes rurais, que vêm tentar a vida na capital, com os laços e valores cristãos de manutenção da família nuclear.

Ao selecionar as famílias economicamente carentes com critérios de renda familiar, os assistentes sociais voluntários acabaram trazendo este "molde familiar", muito diferente do modelo de família que se queria preservar e promover: o da família nuclear, com a presença do marido. Indiscutivelmente, essas mulheres necessitavam de auxílio, mas a transitoriedade dos maridos, associada à suspeita da prática de prostituição, criava um mal-estar em alguns dos dirigentes da creche. Eles temiam estar apoiando o processo de degradação social do núcleo familiar, em vez de promovê-lo. Outro ponto colocado em dúvida dizia respeito ao emprego do tempo livre das mães para o trabalho, que é uma segunda premissa dos idealizadores, ou seja, a creche cuidaria das crianças para que a renda da família pudesse ser aumentada com o trabalho do casal e evitar a sua dissolução em função de motivos financeiros.

O serviço de assistência social era voluntário, o que impedia uma proximidade e uma base de informações maior por parte da instituição. As avaliações ou "sindicâncias" eram realizadas em visitas feitas por voluntários às residências das 
famílias assistidas. Havia reuniões semanais com o objetivo de promover o desenvolvimento familiar.

8.8 As relações (desiguais) com o poder público: a Prefeitura Municipal de Belo Horizonte

A organização decidiu-se pela celebração de convênio com o poder público como forma de ampliar a sua capacidade de atendimento às crianças e às famílias. $\mathrm{O}$ que se constatou é que, apesar de ter conseguido preservar a designação de espírita e uma certa governabilidade interna, a Creche inseriu-se em uma parceria de desiguais, tendo quase sempre que se submeter às determinações, por vezes arbitrárias e quase sempre impositivas, do seu novo parceiro. Aqui nota-se que a proposta de estado racional, como pretende Claus Offe (1998), é ainda mais um ideal que a expressão da relação entre Estado e comunidade.

Um primeiro objeto de análise é o termo de convênio entre o Município e a Associação mantenedora. Neste documento contratual, o Município se compromete a repassar à Associação recursos financeiros e alimentares, desobrigando-se da assistência à saúde das crianças que se fará ao seu arbítrio, baseado na disponibilidade de recursos.

A creche, por sua vez, se obriga a uma lista infindável de controles e oferta de condições, como as instalações julgadas necessárias pelo Município para o armazenamento e manuseio dos alimentos fornecidos, um balanço mensal de receitas e despesas detalhado e trabalhoso (envolve a listagem mensal das crianças, a relação detalhada dos gastos com alimentação perecível, a relação dos cheques utilizados para a compra dos alimentos, etc.), a responsabilidade jurídica e administrativa pelo quadro de funcionários, inclusive pelo vínculo empregatício, embora as diretrizes de remuneração 
sejam dadas pelo poder público (que é uma forma de terceirização, uma vez que a atribuição da prestação deste serviço público, depois da nova Lei de Diretrizes e Bases, passou a ser do Município), a prioridade a ser dada para as crianças assistidas pelos programas sociais do Município, a submissão ao "exército fiscal", que passa a avaliar, nem sempre com base em critérios públicos ou contratuais, "as ações pedagógicas, de saúde, de alimentação e administrativas".

O processo de prestação de contas é tão complexo, que a Secretaria Municipal de Educação promoveu um curso sobre aplicação e prestação de contas, para a qual solicita a presença do coordenador administrativo ou tesoureiro e do contador da entidade convenente.

O Município tem o poder de reter os pagamentos das parcelas do convênio, enquanto que o convenente não possui qualquer poder de sanção ante o descumprimento das obrigações por parte do poder público, cabendo-lhe unicamente a justiça.

Informações sobre acontecimentos que ilustram esta relação foram obtidas em entrevista com o assessor financeiro. A Prefeitura de Belo Horizonte havia mudado o formulário de solicitação de reembolso de vales-transporte dos conveniados. A Creche não foi avisada e enviou a prestação de contas no formulário antigo. O valor gasto nunca foi devolvido, sob a alegação de que o formulário empregado não podia ser aceito, e não houve sequer a possibilidade de nova apresentação da despesa, dada a deficiência na comunicação entre os "parceiros". Este não foi um fato isolado, o que gerou um cuidado meticuloso por parte do assessor financeiro em acompanhar os trâmites do órgão público. Não basta à creche fornecer os documentos e recibos solicitados, de forma geral é necessário acompanhar seu trâmite no órgão público porque a creche pode ser penalizada com base nas negligências de seu parceiro. 
A estrutura burocrática do Município apresenta uma imagem de moderna e informatizada, mas, na verdade, é morosa e negligente, e sacrifica eventualmente os convenentes, devido a suas falhas.

A Prefeitura, por exemplo, criou uma estrutura de centralização da apresentação dos seus documentos, chamada de Sistema Único de Cadastro aos Fornecedores - SUCAF, que teria por função a apresentação de tais documentos para quaisquer outros departamentos que os demandassem. Um dos sinais da ineficácia desta estrutura foi dado pelo próprio órgão público ante a mudança decorrente das LDBs, que passaram a gestão do convênio para a Secretaria Municipal de Educação. Este órgão preferiu solicitar novamente aos convenentes toda a documentação exigida pelo convênio a pedir ao SUCAF (conforme documento analisado pelo pesquisador).

Neste mesmo processo de transferência de responsabilidades das secretarias, o poder público optou pela manutenção de um duplo vínculo subordinativo enquanto julgou conveniente. A creche teve que prestar contas a duas secretarias sobre o mesmo repasse de recursos, com metodologias diferenciadas.

Observou-se, pela redação das cláusulas contratuais, e pelas observações e entrevistas realizadas, que o poder público municipal trata seu parceiro como um "criminoso" potencial, pronto a empregar os recursos públicos para fins particulares e ilegais. Ele se coloca em posição de incolumidade, acima do "mal", e não cria mecanismos eficientes de mediação ou controle de suas negligências, do descumprimento de suas obrigações institucionais e do abuso de poder de seus agentes. 
8.9 A história das qualificações da mantenedora e da creche

A mantenedora tem uma experiência ampla de alianças com o poder público e vem obtendo, com o passar do tempo, as qualificações necessárias ao reconhecimento, por parte do poder público, de sua condição de associação sem fins lucrativos e de interesse público.

A análise de documentos mostra como o projeto original foi sendo obrigado (financeira e legalmente) a ter de estabelecer relações, muitas vezes meramente burocráticas, com grande número de órgãos do serviço público.

Quadro 11: Qualificações e documentação pública da Creche Futuro e de sua mantenedora

\begin{tabular}{|c|c|}
\hline ANO & QUALIFICAÇÕES E DOCUMENTOS OBTIDOS \\
\hline 1977 & $\begin{array}{l}\text { Declaração de utilidade pública municipal da mantenedora expedido pela Prefeitura de } \\
\text { Belo Horizonte. }\end{array}$ \\
\hline 1981 & $\begin{array}{l}\text { Declaração de Utilidade Pública municipal da mantenedora expedido pela Prefeitura } \\
\text { Municipal de Betim. }\end{array}$ \\
\hline 1986 & Certificado de registro na Secretaria Estadual de Educação da Creche Escola Futuro. \\
\hline 1987 & $\begin{array}{l}\text { Registro Geral do Estabelecimento do Lar Escola Futuro, como pré-escola com } 45 \text { alunos } \\
\text { efetivos. }\end{array}$ \\
\hline 1988 & $\begin{array}{l}\text { Registro Geral do Estabelecimento do Lar Escola Futuro, como pré-escola com } 88 \text { alunos } \\
\text { efetivos. }\end{array}$ \\
\hline 1989 & $\begin{array}{l}\text { Comunicado de encerramento do funcionamento da instituição como escola, com } \\
\text { mudança de Creche Escola Futuro e passando a funcionar como Creche Espírita Futuro. }\end{array}$ \\
\hline 1993 & Registro no Conselho Nacional de Assistência Social - CNAS. \\
\hline 1994 & $\begin{array}{l}\text { - Certificado de registro no Conselho Nacional de Assistência Social - CNAS. } \\
\text { - A Escola Municipal Prof. Christovam Colombo dos Santos coloca à disposição três } \\
\text { funcionárias, mas declara manter a supervisão pedagógica. }\end{array}$ \\
\hline 1996 & $\begin{array}{l}\text { - Atestado de funcionamento expedido pelo Promotor de Justiça. } \\
\text { - Atestado de cadastramento de entidade de Ação Social dado à mantenedora pela } \\
\text { Secretaria de Trabalho e Ação Social para recebimento de subvenções do poder estadual. }\end{array}$ \\
\hline 1997 & $\begin{array}{l}\text { - Atestado de funcionamento da mantenedora expedido pelo Juiz de Direito Titular da } \\
15^{\text {a }} \text {. Vara Cível. } \\
\text { - Registro no Conselho Municipal dos Direitos da Criança e do Adolescente. }\end{array}$ \\
\hline 1998 & \begin{tabular}{|l}
$\begin{array}{l}\text { Requerimento de atestado de funcionamento da } \\
\text { Desenvolvimento Social. }\end{array}$
\end{tabular} \\
\hline 1999 & $\begin{array}{l}\text { Certificado de "Entidade de Fins Filantrópicos" emitido pelo Conselho Nacional de } \\
\text { Assistência Social (válido até 2002). }\end{array}$ \\
\hline 2000 & $\begin{array}{l}\text { - Ato Declaratório da Gerência Executiva do INSS, reconhecendo o direito à isenção das } \\
\text { contribuições } \\
\text { - Prioridades para a rede de creches expedida pela Prefeitura Municipal de Belo } \\
\text { Horizonte, demandando: projeto político pedagógico, exigência de participação em } \\
\text { fóruns e cursos da PBH, submissão à SMAB e seu programa alimentar, promoção de } \\
\text { gestão democrática e política de formação de profissionais. }\end{array}$ \\
\hline
\end{tabular}

(Continua) 
(Conclusão)

\begin{tabular}{c|l}
\hline ANO & \multicolumn{1}{c}{ QUALIFICAÇÕES E DOCUMENTOS OBTIDOS } \\
\hline 2001 & $\begin{array}{l}\text { - Publicação do Decreto de Utilidade Pública Federal. } \\
\text { - Atestado de funcionamento do Conselho Municipal de Assistência Social de Belo } \\
\text { Horizonte. } \\
\text { - Documento de autorização de funcionamento de educação infantil na Creche Futuro por } \\
\text { um ano. } \\
- \text { Plano de trabalho da Secretaria Municipal de Assistência Social. }\end{array}$ \\
\hline 2002 & $\begin{array}{l}\text { Inscrição no Conselho Municipal de Assistência Social da Prefeitura de Belo Horizonte } \\
\text { (válido até 2005). }\end{array}$ \\
\hline
\end{tabular}

Fonte: Arquivos da Creche Futuro

Encontram-se também relatórios anuais de atendimento solicitado pela Secretaria de Trabalho, Ação Social, Criança e Adolescente, para justificar o repasse de recursos.

Observa-se que a aquisição dos documentos necessários ao reconhecimento da imunidade pelo Poder Executivo e à obtenção das isenções previstas por lei foi lento e gradual, em parte por causa das exigências legais, em parte devido aos trâmites burocráticos do Estado, em parte pela falta de um planejamento escrito para a obtenção desses direitos e benefícios.

8.10 A progressiva profissionalização e afastamento dos voluntários das atividades de creche

O projeto original da Creche contava com um grande número de voluntários nas atividades de cuidado com as crianças. A maioria dos serviços especializados foi sendo desativada ou funciona em caráter precário, quando dirigidos por voluntários, como o serviço de Educação Física (que passou a ser de competência das monitoras), o serviço de Psicologia (que é irregular, sempre focalizado em um ou mais voluntários, mas que não se constituiu em equipe), o serviço de assistência social (que sempre 
dependeu de voluntários formados, que se queixavam na interferência das lideranças) e o serviço médico.

Dentre os serviços voluntários que não exigiam uma formação mínima, temse o sistema de coordenadoras de turno. Esse sistema foi sendo paulatinamente esvaziado, a partir do momento de contratação de um coordenador administrativo, como exigência das diretrizes da Prefeitura de Belo Horizonte ${ }^{106}$.

Observou-se que ainda há voluntários ligados às seguintes atividades da creche: iniciação musical, cuidados com as crianças do berçário e evangelização infantil.

Por que o vínculo do voluntário foi tão precário? As conclusões a que esta pesquisa chegou, que são preliminares e sem poder de generalização, por necessitarem de novos estudos para tal, é que onde havia atividades em equipe com lideranças e preocupação de continuidade, as atividades se mantiveram por mais tempo que naquelas onde os voluntários se fixaram individualmente. Já onde as atividades não são acompanhadas pelos olhos da alta gestão da creche, este vínculo tendeu a ser mais precário.

\subsection{A nova estrutura organizacional de 1998}

A próxima mudança observada foi formalizada na estrutura organizacional de 1998. Esta formalizou um conselho de classe, criou uma assessoria de secretaria (que não funciona mais hoje) e uma assessoria financeira e introduziu as demais atividades assistenciais, transformando as atividades de creche em Departamento do Menor. As

\footnotetext{
${ }^{106}$ Prioridades propostas para o biênio 98/99 nas creches da Regional Oeste
} 
atividades assistenciais foram divididas em três departamentos: Departamento de Saúde, Departamento Assistencial e Departamento de Oficinas.

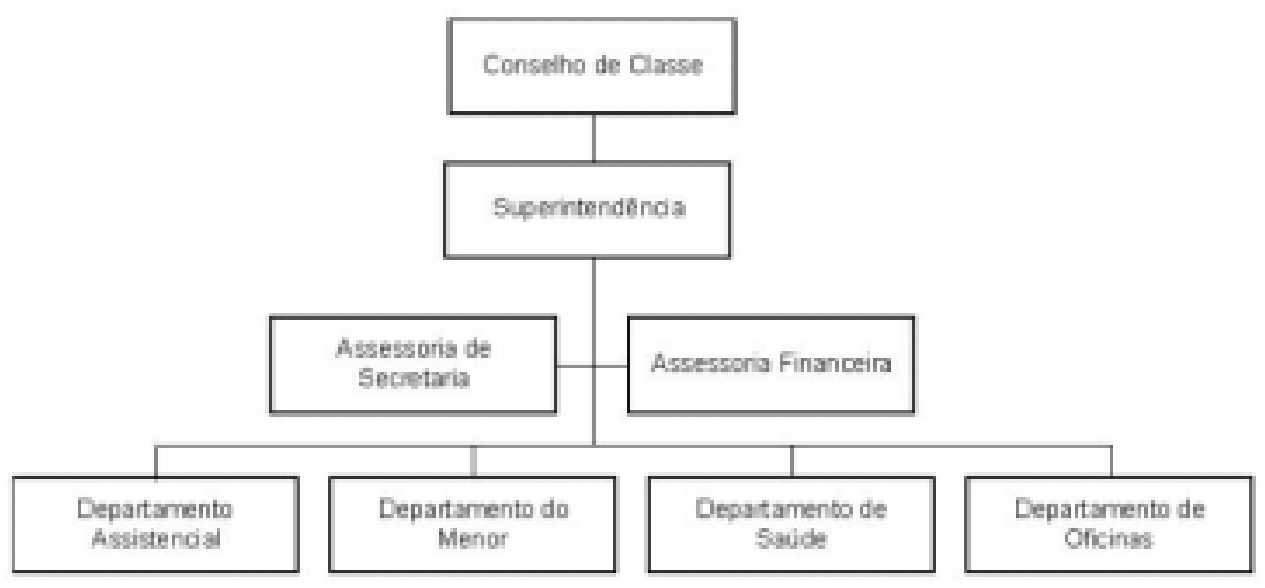

Figura 18: Estrutura organizacional da Creche Futuro em 1998 
9. ESTRUTURA, FUNCIONAMENTO E CULTURA ATUAIS DA CRECHE FUTURO

Santana costuma dizer: - Raspe-se um pouco qualquer mineiro: por baixo, encontrar-se-á o político... - João Guimarães Rosa

\subsection{Estrutura atual da Creche Futuro}

A estrutura encontrada no regimento interno da Creche Futuro mudou pouco desde a reforma de 1998. Houve apenas a troca de designações de dois departamentos, como se pode ver na figura abaixo:

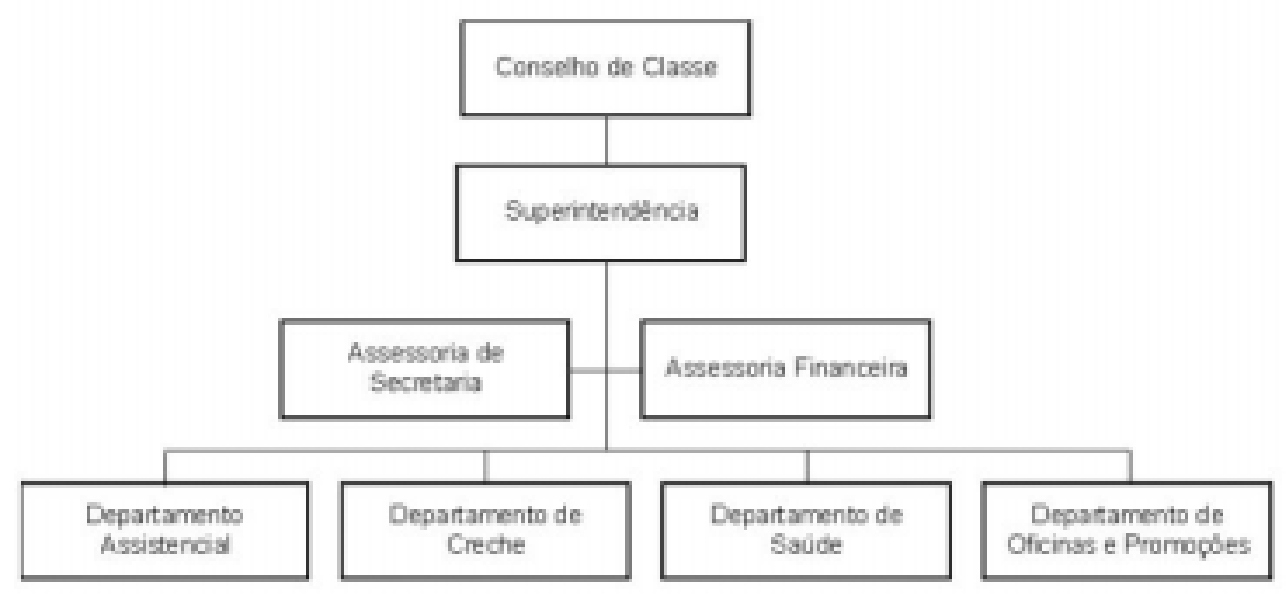

Figura 19: Estrutura organizacional da Creche Futuro em vigor 


\subsubsection{Conselho de classe}

O Conselho de Classe é uma estrutura criada a partir da demanda da Prefeitura de Belo Horizonte, que tinha o objetivo de tornar mais comunitárias e participativas as creches, com a presença de pais e comunidade em sua gestão, mas que foi reapropriada segundo a lógica de abertura restrita, própria da trajetória da organização. Esse conselho é composto, portanto, pelo superintendente e pelos chefes de departamento, e presidido pelo diretor administrativo da mantenedora. Criou-se uma reunião mensal de pais, um espaço paralelo e não deliberativo, para a receber as famílias das crianças.

Nas diversas sessões do conselho de classe de que o pesquisador participou, relatando as observações e propondo a implantação de serviços na organização, observou-se que se tratava de um órgão sem efetividade. Houve o envolvimento interessado dos diretores da mantenedora, do superintendente e do coordenador administrativo, mas a presença dos chefes de departamento foi irregular, e os chefes dos Departamentos de Saúde e de Oficinas e Promoções não compareceram a nenhuma delas (foram cinco), nem enviaram substitutos, o que dificultou a deliberação de propostas. Ademais, as propostas aprovadas não foram implantadas.

\subsubsection{Superintendência e chefias de departamentos}

O superintendente é escolhido pela diretoria da mantenedora e é a autoridade máxima formal da creche. Ele tem diversas funções como a representação da organização perante os órgãos públicos, o controle e avaliação das ações, a coordenação

e supervisão dos departamentos, as funções de seleção, admissão, treinamento e 
demissão de empregados, a elaboração de rotinas, a guarda e a verificação de documentos. Ele poderia ser remunerado, mas o cargo vem sendo ocupado por voluntários.

Na realidade, entretanto, o ocupante deste cargo não exerce o poder formal previsto no regimento interno. Ele sofre interferência do voluntarismo dos chefes de departamento, que têm mais arbítrio do que dispõe o documento sobre seus territórios. Isto foi afirmado pelo superintendente em exercício à época da pesquisa de campo.

Os chefes dos departamentos são escolhidos pelo diretor administrativo da mantenedora, e não pelo conselho de classe ou pelo superintendente, o que enfraquece mais ainda a posição deste último. À exceção do Chefe do Departamento de Creche, os demais não possuem empregados sob sua gestão. Não há um Departamento Administrativo, razão pela qual o Departamento de Creche se responsabiliza por toda a gestão de pessoal e da infra-estrutura necessária à consecução dos objetivos dos demais. Essa é uma herança do processo de fundação, que ainda não foi superada.

Como se pode observar, a divisão em chefias não obedeceu a um critério funcional, posto que três departamentos têm cunho assistencial, mas lideranças distintas. A lógica da divisão dos departamentos é a lógica da territorialização, mencionada anteriormente, ou seja, colocaram-se líderes de destaque em territórios próprios de ação para evitar conflitos. Esta lógica ficou evidente quando se propôs uma reavaliação do traçado da estrutura organizacional. Ele não foi feito para a Creche Futuro e as discussões foram levadas à mantenedora, para que fosse implementado nas quatro unidades geográficas ligadas a ela. Esta é uma proposta está em trânsito desde 15 de março de 2002 e, embora tenha sido bastante discutida, ainda não foi iniciada a sua implantação. 
Existe um coordenador-administrativo cujas atribuições não se acham contempladas no presente organograma. Originalmente, ele seria subordinado do Departamento de Creche, mas na realidade ele age como um elo de ligação do superintendente com o cotidiano, uma vez que é responsável pela supervisão de atividades, que vão além da esfera do Departamento de cCreche, e por todo o pessoal contratado.

\subsubsection{Estrutura, temporalidade e planejamento}

A presente estrutura gera pelo menos três ciclos temporais distintos. O primeiro é o dos empregados contratados, incluso o Coordenador Administrativo, que trabalham diariamente, cinco dias por semana. O segundo é o dos voluntários, Chefes de Departamento e Superintendente que atuam uma ou duas vezes por semana. O terceiro é o do Conselho de Classe, que regimentalmente se reuniria trimestralmente, mas à época da coleta de dados, vinha se reunindo uma ou duas vezes por ano. Entretanto, realizaram-se, de forma excepcional, reuniões mensais, devido ao relatório proposto.

Estsa estrutura temporal da organização gera problema na solução de conflitos, uma vez que um impasse ou problema que envolva os empregados tem que ser resolvido pelo Coordenador Administrativo ou, por telefone, com o Superintendente. Os problemas que envolvem os departamentos demandam uma atuação direta do Superintendente ou são levados sem mediação do Conselho à diretoria da mantenedora. O Coordenador Administrativo culmina por ser uma autoridade de referência dos empregados, dada periodicidade da presença do Superintendente. Esse tipo de arranjo favorece bastante os comentários e "fofocas", uma vez que não há um processo hábil de 
comunicação nem instâncias abalizadas de consultas. Esse fenômeno foi observado durante o processo de afastamento do Superintendente.

Os documentos referentes a planejamento encontrados foram dois: os relatórios anuais e o projeto político-pedagógico. O primeiro se atém mais a aspectos físicos da organização, aos serviços da creche e à quantificação das ações, mas não há uma prática de planejar a curto, médio e longo prazos os serviços e atividades em curso na Creche Futuro. O segundo orienta a ação pedagógica, mas só obteve alguma efetividade com a contratação de uma pedagoga. Seus conteúdos não influenciam o planejamento administrativo da organização, até onde se pôde observar.Esse planejamento feito em nível de chefias e superior é o cumprimento formalista de uma exigência da burocracia da Secretaria de Educação. Mais uma vez observa-se um esvaziamento de sentido da ação imposta pelo "parceiro" estatal.

O planejamento real das atividades fica a cargo do arbítrio dos Chefes de Departamento, que criam e extinguem atividades, e podem, até mesmo, não comunicálas às esferas superiores. Eles fazem esse planejamento semana-a-semana, de forma não objetivo, pois, não estabelecem metas para o período, exceção feita à creche, que designa o número de crianças que serão atendidas e faz o calendário anual.

\subsubsection{Atividades em curso e respectivas subordinações}

Foram mapeadas as seguintes atividades sob a responsabilidade dos respectivos departamentos.

O Departamento Assistencial, além da organização de duas grandes campanhas anuais (campanha de Natal e campanha do agasalho), realiza as seguintes atividades: 


\section{Quadro 12: Atividades do Departamento Assistencial}

\begin{tabular}{ll|l}
\hline \multicolumn{2}{c|}{ Atividade } & \multicolumn{1}{c}{ Objetivos } \\
\hline $\begin{array}{ll}\text { Curso para } \\
\text { Gestantes }\end{array}$ & $\begin{array}{l}\text { Orientar gestantes de baixa renda nos aspectos médico, jurídico, psicológico e } \\
\text { espiritual. }\end{array}$ \\
\hline $\begin{array}{ll}\text { Confecção de } \\
\text { Cestas }\end{array}$ & $\begin{array}{l}\text { Montar cestas de alimentos a serem distribuídas para as famílias assistidas pela } \\
\text { mantenedora. }\end{array}$ \\
Alimentos & & Realizar grupos de discussão sobre temas diversos com as famílias assistidas pela \\
\hline Encontro com as & Ramílias & casa. \\
Assistidas &
\end{tabular}

Fonte: Descrição de Atividades

O Departamento de Creche mantém as atividades abaixo, principalmente

com mão-de-obra contratada.

Quadro 13: Atividades do Departamento de Creche

\begin{tabular}{l|l}
\hline \multicolumn{1}{c|}{ Atividade } & \multicolumn{1}{c}{ Objetivos } \\
\hline Berçário & Cuidar de crianças de 0 a 2 anos pertencentes à creche. \\
\hline $\begin{array}{l}\text { Monitoria de } \\
\text { Creche }\end{array}$ & Cuidar de crianças e as educar, quando matriculadas na creche. \\
\hline Cozinha & $\begin{array}{l}\text { Preparar lanches para algumas atividades da Creche Futuro e refeições para as } \\
\text { crianças e colaboradores da creche. }\end{array}$ \\
\hline $\begin{array}{l}\text { Supervisão de } \\
\text { Turno }\end{array}$ & $\begin{array}{l}\text { Supervisionar o funcionamento da creche como um todo e solucionar os problemas } \\
\text { que eventualmente surgem. }\end{array}$ \\
\hline $\begin{array}{l}\text { Serviço } \\
\text { Pedagógico }\end{array}$ & $\begin{array}{l}\text { Elaborar o projeto político pedagógico, supervisiona as monitoras e acompanhar as } \\
\text { crianças. }\end{array}$ \\
\hline Fonte: Descrição de Atividades
\end{tabular}

As crianças da creche assistem a aulas de evangelização infantil, ministradas por um grupo de voluntários, que se encontram subordinados ao Departamento de Evangelização Infantil da mantenedora que não têm qualquer vínculo com o serviço pedagógico.

Quadro 14: Evangelização infantil

\begin{tabular}{l|l}
\hline \multicolumn{1}{c|}{ Atividade } & Objetivos \\
\hline $\begin{array}{l}\text { Evangelização } \\
\text { das Crianças da }\end{array}$ & Dar aulas de evangelização infantil para as crianças da creche \\
Creche & \\
\hline \multicolumn{2}{l}{ Fonte: Descrição de Atividades }
\end{tabular}

O Departamento de Oficinas e Promoções mantém o maior número de atividades: 
Quadro 15: Atividades do Departamento de Oficinas e Promoções

\begin{tabular}{|c|c|}
\hline Atividade & Objetivos \\
\hline Bazar Beneficente & $\begin{array}{l}\text { Confeccionar produtos artesanais e os colocar à venda em eventos beneficentes. } \\
\text { (Artigos bordados, tricô, crochê, tapeçaria e peças de costura) }\end{array}$ \\
\hline $\begin{array}{l}\text { Oficina } \\
\text { Costura }\end{array}$ & $\begin{array}{l}\text { Confeccionar e dar acabamento em peças de costura para as diversas atividades } \\
\text { assistenciais. }\end{array}$ \\
\hline $\begin{array}{ll}\text { Oficina } & \text { de } \\
\text { Enxovais } & \end{array}$ & Preparar "kits" de enxovais para gestantes e bebês recém-nascidos. \\
\hline $\begin{array}{l}\text { Curso de Pintura } \\
\text { em Tecidos com } \\
\text { Pincel }\end{array}$ & realizar trabalhos de pintura em tecidos com pincel. \\
\hline $\begin{array}{ll}\text { Curso de } \\
\text { Manicure }\end{array}$ & Formar manicures profissionais. \\
\hline $\begin{array}{l}\text { Curso } \\
\text { Culinária }\end{array}$ & Ensinar a preparação de pratos simples e de baixo custo destinados a lanches. \\
\hline Curso de Costura & Formar costureiras profissionais segundo o método Ioli. \\
\hline Enxovalzinho & Preparar enxovais para serem distribuídos a gestantes de baixa renda. \\
\hline
\end{tabular}

O Departamento de Saúde possui os serviços de farmácia e odontologia que funcionam de forma regular com profissionais-voluntários. Há atendimentos médicos em um ambulatório, mas este vem sendo realizado de forma irregular.

Quadro 16: Atividades regulares do Departamento de Saúde

\begin{tabular}{l|l}
\hline \multicolumn{1}{c|}{ Atividade } & \multicolumn{1}{c}{ Objetivos } \\
\hline Farmácia & $\begin{array}{l}\text { Distribuir medicamentos para a comunidade atendida pela Creche Futuro mediante } \\
\text { apresentação de receita médica. }\end{array}$ \\
\hline Dentista & $\begin{array}{l}\text { Prestar atendimento odontológico às crianças da Creche Futuro, atuando tanto na } \\
\text { prevenção quanto no tratamento de problemas odontológicos. }\end{array}$ \\
\hline
\end{tabular}

Fonte: Descrição de Atividades

Encontraram-se ainda atividades realizadas regularmente sem subordinação hierárquica a nenhum dos departamentos como as seguintes:

\section{Quadro 17: Atividades sem vínculo departamental}

\begin{tabular}{l|l}
\hline \multicolumn{1}{c|}{ Atividade } & \multicolumn{1}{c}{ Objetivos } \\
\hline $\begin{array}{l}\text { Assistência } \\
\text { Jurídica }\end{array}$ & $\begin{array}{l}\text { Prestar serviços gratuitos de assistência jurídica para a comunidade assistida da } \\
\text { Creche Futuro. }\end{array}$ \\
\hline Sopão & $\begin{array}{l}\text { Distribuir sopa, material escolar e alimentos para a comunidade da ocupação na } \\
\text { região da Via-Expressa }\end{array}$ \\
\hline
\end{tabular}

Fonte: Descrição de Atividades

\footnotetext{
${ }^{107}$ Um dos grandes corredores de acesso da capital mineira. Esta comunidade formou-se a partir da ocupação irregular de terrenos sob e a redor de um dos viadutos.
} 
9.2 Recursos financeiros para manutenção da creche.

Os convênios mantidos com a Secretaria Municipal de Educação da Prefeitura Municipal de Belo Horizonte e com a Secretaria de Trabalho, Ação Social, Criança e Adolescente do Governo do Estado de Minas Gerais - que administra um recurso federal - asseguram a cobertura das principais despesas operacionais fixas, como, folha de pagamento, alimentação e taxas de serviços (água, energia elétrica e telefone). Eles não cobrem, entretanto, despesas administrativas contingenciais, como reformas da estrutura física, rescisão de contratos de empregados, etc. Essas outras despesas são cobertas pelas fontes da mantenedora, e as principais fontes regulares de recursos financeiros são as doações de pessoas físicas e jurídicas, recolhidos por carnês, e os recursos obtidos através de eventos, como bazar de Natal, jantares, festas beneficentes, etc.

Foi comunicada, no último relatório da mantenedora, a obtenção de recursos junto à grantmaker Vitae, Apoio à Cultura, Educação e Promoção Social, mas os valores não foram registrados.

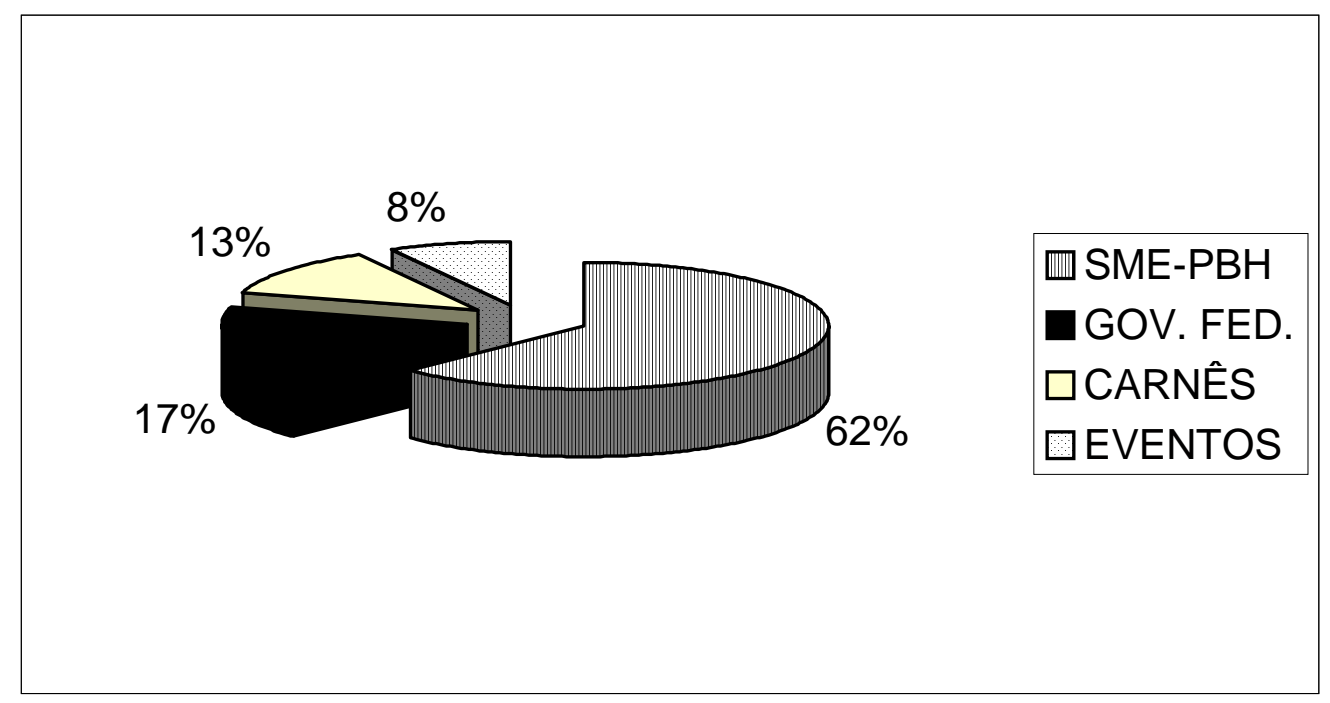

Figura 20: Fontes de recursos financeiros da Creche Futuro 
O sistema de carnês foi associado, há alguns anos, ao pagamento da conta de energia elétrica da principal concessionária mineira, o que reduziu bastante o problema de inadimplência e de atrasos no pagamento, e possibilitou melhor gerenciamento do pagamento das despesas. Cerca de $65 \%$ dos recursos de carnês da Creche Futuro já são recolhidos e repassados pela Companhia Energética de Minas Gerais - CEMIG.

As despesas são rigorosamente controladas pelo assessor financeiro, que coleciona todas as notas fiscais, cheques emitidos e outros documentos comprobatórios, para fins contábeis.

O sistema de gestão aplica os recursos eventualmente adiantados pelas organizações de estado e possui uma reserva financeira, o que impede o endividamento decorrente das multas e atrasos de pagamentos e a insatisfação dos empregados remunerados, em razão de eventuais atrasos.

Esta estrutura é responsável pelas relações com a Prefeitura e o Governo do Estado, e fornece todas as informações e relatórios demandados. Não foi encontrado registro, nos documentos, ou informações, na observação de campo, de problemas com relação a aspectos financeiros da aliança entre a Creche Futuro e os órgãos de estado.

As contas são aprovadas anualmente por assembléia geral da mantenedora e são avaliadas por uma comissão fiscal interna, mas independente. Uma contabilidade faz os lançamentos da mantenedora, e a diretoria publica um relatório anual de atividades que é disponibilizado a quem queira ler, havendo, para isso, exemplares na biblioteca e na secretaria da mantenedora.

As receitas e despesas não são de domínio amplo dos membros da Creche Futuro, mas existe transparência contábil. A gestão financeira não é participativa, mas é também transparente. 
Todo o sistema de controle financeiro é realizado por voluntários, do assessor financeiro à contabilidade (que a rigor é uma organização de mercado, que realiza ações de responsabilidade social). Eles têm credibilidade em toda a organização, que lhes confia a administração de recursos próprios das atividades assistenciais e valores arrecadados em eventos beneficentes para emprego já destinado.

\subsection{Processos de comunicação na Creche Futuro}

Um dos pontos mais negligenciados pela gestão da Creche Futuro diz respeito aos processos de comunicação. A creche conta com um número relativamente pequeno de empregados, mas um número expressivo de voluntários, crianças e famílias da comunidade.

Os principais processos de comunicação são orais. Os empregados se reúnem semanalmente com o Coordenador Administrativo, e as famílias das crianças se reúnem mensalmente com uma equipe de membros da creche e do Departamento Assistencial.

Os murais não são explorados como espaços de comunicação e funcionam mais para fins pedagógicos ou doutrinários. Existe um boletim trimestral da mantenedora que é distribuído gratuitamente na Creche Futuro, mas ele envolve um grande universo de temas e é pouco procurado e lido pelo público freqüentador da Creche Futuro. Não há boletim local de notícias.

No espaço dos departamentos de Saúde, Assistencial e de Oficinas e Promoções as informações são levadas pelos coordenadores das equipes ou pelos chefes de departamentos, em reuniões nas quais este é um objetivo marginal. Não existe 
mecanismo de informação escrita dos coordenadores sobre questões de interesse institucional.

Este caráter "familiar" de gestão da informação e o sigilo andam par a par com o surgimento de comentários fantasiosos sobre pessoas e decisões que afetam, de alguma forma, o dia-a-dia da organização, como já foi registrado anteriormente. O pequeno porte da organização em si não assegura o trânsito de informações entre seus membros.

Como já foi dito, as reuniões do conselho de classe não são registradas e suas resoluções são divulgadas oralmente. Não há espaços internos de divulgação impressa de decisões e informações referentes às atividades realizadas na Creche Futuro.

Há um problema de trânsito de informações entre Prefeitura e Creche. Em campo, foram narradas, aos pesquisadores, situações em que informações incorretas são dadas por funcionários da Prefeitura aos empregados da creche, gerando tensões. Um dos casos relatados envolve um suposto aumento de salário, que provocou desconfiança entre os empregados e a gestão financeira da Creche.

As informações escritas e resoluções que vêm da prefeitura são arquivadas (em um arquivo de difícil recuperação...) e não há uma espécie de clipping de notícias que envolvem a Creche, a Educação Infantil ou o Terceiro Setor.

A comunicação com outras creches é formal, restringe-se à participação da Creche Futuro em uma reunião promovida pela Prefeitura de Belo Horizonte, mas esse encontro não gera relações em forma de rede.

Há promoção de eventos principalmente ligados ao movimento espírita, alguns (poucos) voltados à reflexão sobre a atividade de promoção social. Não há 
notícias ou registros de promoção de eventos ou de participação em eventos relacionados ao Terceiro Setor, de cunho institucional. Esses eventos se restringem apenas aos que são promovidos pelo poder público e nos quais a participação da Creche é uma espécie de obrigação a ser cumprida.

9.4 Políticas de gestão de pessoas

Há três segmentos cujas políticas de gestão de pessoas podem ser analisadas: o dos empregados, o dos voluntários e o dos dirigentes.

\subsubsection{Empregados}

A maioria dos empregados é contratada em regime "celetista", mas tem as regras de remuneração (que são a maior despesa operacional da creche) "ditadas" pela Prefeitura de Belo Horizonte e pelas relações entre sindicato de empregados e sindicato patronal. A creche, portanto, cumpre um papel de terceirização desta mão-de-obra, e não haverá uma margem de gestão de salários ou possibilidade de implantar um programa de remuneração ou de carreiras, enquanto seus principais recursos continuarem sendo oriundos dos dois convênios com o Estado.

Há uma exigência de escolaridade mínima para cozinheira, monitoras e para o diretor de creche, as duas últimas devido à regulamentação da profissão. Uma vez selecionados, os treinamentos de monitoras e cozinheiras são dados pela Prefeitura de Belo Horizonte, mas são treinamentos operacionais, não qualificantes.

A seleção dos empregados é feita por uma comissão composta pelo superintendente, pelo diretor do departamento de creche, pelo coordenador 
administrativo, pela pedagoga (quando se estão selecionando monitores) e por uma psicóloga voluntária, que aplica alguns testes gráficos e de habilidades específicas. Um dos critérios observados nos processos de seleção é o da adaptabilidade do candidato à cultura e seus respectivos valores, como a dedicação e a paciência.

Não há "treinamento introdutório", e o processo de socialização vai sendo feito informalmente, pelo conhecimento paulatino dos colegas, dos superiores e da organização e pela realização do trabalho para o qual o empregado foi contratado.

Não há processos formais de avaliação de desempenho, que é feita com base na supervisão exercida pelos superiores, portanto, pelos incidentes críticos que vão destacando o profissional aos olhos do corpo gestor.

\subsubsection{Voluntários}

Embora se aceitem voluntários de qualquer origem, a maioria deles é recrutada na mantenedora. Em reunião inicial com os diretores da mantenedora, eles asseguraram um dos valores partilhados por voluntários e dirigentes (mas não pelos empregados) que afirma ser "a razão de existir da creche, a oferta de trabalho voluntário para os freqüentadores da casa"108 (eles estão se referindo à mantenedora).

Assim, os voluntários são recrutados principalmente por convite direto ou por convite geral nas reuniões em curso na mantenedora. Essa informação foi confirmada nas entrevistas com os voluntários. Não há registro de ações para atrair membros da comunidade às atividades da creche, embora haja poucas mães que se voluntariam espontaneamente no auxílio da limpeza das salas de aula (não há mecanismos de coerção para que façam isto) e algumas pessoas que se apresentam na

\footnotetext{
${ }^{108}$ Extraído do diário de campo.
} 
secretaria da creche oferecendo trabalho voluntário. Estas são encaminhadas às atividades consideradas deficitárias, como o berçário.

Os voluntários assinam o "termo de adesão ao serviço voluntário", exigido pela lei 9606, de 18 de fevereiro de 1998.

Eles geralmente são recrutados diretamente pelas equipes de trabalho, mas não houve qualquer iniciativa coletiva, por parte da gestão da creche, durante o período em que a equipe lá esteve.

Os voluntários são acompanhados pelo coordenador de equipe, e não há igualmente um treinamento introdutório institucional para eles, o que fortalece os valores territoriais. Não há também um programa de acompanhamento nem cursos de qualificação desses voluntários. Eles aprendem e desenvolvem sua capacidade de realizar as atividades nos respectivos postos.

A rotatividade, um fenômeno observado durante as pesquisas, será discutida nas entrevistas.

\subsubsection{Dirigentes}

A escolha dos dirigentes, sejam coordenadores, chefes de departamento, superintendente ou diretores, se passa no âmbito da mantenedora quando da aprovação de uma atividade nova, ou, posteriormente, no interior das equipes. A lógica é semelhante à das organizações espíritas observadas pelos antropólogos, ou seja, a da hierarquia de potencial descrita por CAVALCANTI (1983), que destaca o "mérito, a moral individual e nas próprias circunstâncias do trabalho", ao que esta pesquisa adicionaria a dedicação e a identificação com o Espiritismo, com seus valores, seus imperativos éticos e o conhecimento doutrinário, assim como o trânsito junto ao 
território onde a atividade está sendo realizada. O critério de antiguidade na mantenedora e no trabalho ${ }^{109}$ também possui algum peso, mas pode ser invertida, especialmente se a estrutura de poder vigente deseja mudanças na organização e tem capacidade de influência para tanto.

Em espaços específicos, a formação profissional pode ser um critério, mas a habilitação técnica dificilmente será o critério principal na escolha de um dirigente, na lógica da Creche Futuro e de sua mantenedora. O líder carismático costuma escolher o seu sucessor ao identificar quem mais teria "capacidade" para "assumir a tarefa".

Os chefes de departamento, na prática, não são escolhidos pelos dirigentes da mantenedora, que aprovam sucessores indicados pelos líderes de território, como um ato de boa convivência. Os líderes, por sua vez, fazem escolhas conservadoras, mas houve uma situação de falecimento de um chefe de departamento em que a atividade que ele coordenava foi dividida entre seu filho e uma das coordenadoras de equipe (e antiga superintendente da Creche).

O Superintendente, ao contrário, é uma pessoa de confiança da diretoria, que é identificada como se fosse uma peça de um grande quebra-cabeça, porque precisa compor com a realidade institucional existente.

A análise da estrutura e funcionamento aponta para a coexistência de diferentes referências temporais entre voluntários, dirigentes e empregados. Este tipo de padrão (voluntário e dirigente semanais, empregado diarista) deve ser mais bem investigado, por ser mais incidente nas organizações de terceiro setor que nas organizações de Estado ou Mercado. Esta inversão possui implicações possíveis para os

${ }^{109}$ Discutida por LEWGOY, 1998. 
processos de decisão, as relações hierárquicas e os processos de comunicação que devem ser mais conhecidas.

Observou-se uma dificuldade do poder público perceber o caráter distintivo da creche, ao empregar processos de gestão e políticas de gestão, como foi o caso dos conselhos de gestão, incompatíveis com a identidade de seus parceiros. Aliada à quase ausência de mecanismos e instâncias de reciprocidade, como foi mostrado neste capítulo, a relação público-privado ainda se encontra distante do ideal apontado por seus ideólogos.

O problema das fontes de recursos afeta a possibilidade do estabelecimento de políticas de remuneração dos empregados. No caso desta creche, a política de remuneração é quase que inteiramente controlada pelo Município, que por sua vez, se beneficia da possibilidade de contratar por terceiros em regime "celetista". Com que extensão, as organizações brasileiras de Terceiro Setor se encontram no mesmo impasse que Creche Futuro para adotarem políticas de gestão de pessoas capazes de reter e desenvolver bons empregados? Esta pergunta é crucial ante a promessa de um novo espaço laboral que se encontra no discurso de muitos entusiastas do Terceiro Setor.

Outro fenômeno encontrado apenas marginalmente na literatura foi a separação entre o espaço de atuação profissional e o espaço de atuação do voluntário, assim como a existência de conflitos entre estes dois segmentos. Este fenômeno obriga os pesquisadores a perguntarem em que condições o trabalho voluntário é um diferencial sinérgico das organizações do Terceiro Setor. 


\title{
10. A INSERÇÃO DOS VOLUNTÁRIOS
}

\author{
"Teus olho tão singular \\ Dessas trancinhas tão preta \\ Qero morer eim teus braço \\ Ai fermosa marieta" (João Guimarães Rosa)
}

Escolheu-se um dos territórios da organização do qual se entrevistaram oito voluntários. Todos eles afirmam-se espíritas e estão há mais de um ano vinculados a alguma organização espírita, tendo freqüentado reuniões de estudos. Considerou-se que todos tiveram contato com o ethos e a visão de mundo do movimento espírita, embora nem todos tivessem sido expostos ao projeto e aos valores do fundador da Creche Futuro.

\subsection{História familiar}

Seis dos oito voluntários estudados são voluntários de primeira geração, isto é, entendem que os pais não se voluntariavam, embora fossem caridosos e dispostos a doar dinheiro ou bens para os necessitados. Uma fala típica é a que se reproduz abaixo:

A minha mãe sempre foi uma criatura de tirar a roupa dela e dar pros outros. Ela era italiana e nunca aprendeu a falar português. Falava tudo enrolado. Mas ela sempre foi uma ótima pessoa. Mas assim com voluntária de trabalhar, ela nem sabia se comunicar direito em português. Mas era muito boa pras pessoas. (Voluntário 7)

Uma voluntária, mesmo estimulada, trata de forma sumária a experiência de sua mãe, dizendo:

Costura pra creche também. Mesmo estilo assim que eu. Não ia, mas fazia em casa. E a gente foi criada assim já participando. (Voluntário 2) 
Um dos entrevistados, entretanto, acentuou muito a experiência de sua mãe como voluntária. Ele relata que ela se dedicou aos necessitados em sua própria casa, tendo levado pessoas necessitadas para lá e cuidado delas ocasionalmente, além do auxílio contínuo que ela dava a vizinhos em condições financeiras piores que as deles. Embora este participante tenha relatado experiências de teor não muito diferente dos demais, sua ênfase sugere uma identificação maior e uma significação diferenciada da experiência de voluntariado.

Mas minha mãe, ela se dedicou por inteiro ao pobre. Aqueles que eram mais pobres que nós. Então ela não só se dedicava, como nos ensinou. Nos mostrando seus exemplos.(...) e por mais de uma vez eu vi a mamãe tirar o agasalho dela e colocar no corpo dessas senhoras que estavam assim com aqueles vestidinhos de tecido cru sobre a pele somente e aquele frio. Então ela tirava e punha....a gente esquentando no fogo assim no fogão de lenha. Uma vez eu falei "mamãe, a senhora num pode fazer isso", "fazer o quê, meu filho", "a senhora não pode dar o seu agasalho que a senhora vai sentir frio".E ela dizia assim "não, meu filho. Deus dá um jeito. A mamãe ganha outro". E essa é uma expressão dela que ficou gravado na minha alma a fogo. (Voluntário seis)

Dos entrevistados, foi ele que apresentou a maior trajetória de experiências voluntárias. Iniciou atividades ainda solteiro, tendo consistentemente se voluntariado em diferentes organizações, de diferentes bases filosóficas (católicas, leigas e espíritas) e participado como membro, como fundador e como diretor. Esse caso não permite que se associe a experiência concreta dos pais com o comportamento de se voluntariar, mas sugere que o pesquisador deste campo se interesse pelo significado subjetivo dado pelo participante a este tipo de experiência.

Esta situação sugere que se proponha a realização de estudos posteriores nos quais seja analisada a possibilidade de se considerar a relação do sujeito com sua imago parental como um dos indicadores de motivação e comprometimento com o voluntariado. 
Outro ponto da história familiar que foi abordado nas entrevistas diz respeito ao apoio da família atual às atividades que desenvolve, que seria uma espécie de suporte social. As respostas dos voluntários são variadas, mas houve muitos relatos de familiares que, a princípio, eram contra a realização desta atividade e que, aos poucos, ou se tornaram indiferentes ou passaram a apóia-las.

Meu marido, no princípio, ele era muito mandão, mas só no princípio, então eu mentia para ele. (...), mas agora ele me ajuda a fazer as compras, sabe. Vai, traz de carro para mim. (Voluntário 5)

Meu marido me apóia muito. Ele não reclama. Ele sabe o que eu estou fazendo aqui. Vem, ajuda. Nunca reclamou. (Voluntário 8)

10.2 Trajetória anterior à Creche Futuro dos voluntários estudados.

Os entrevistados possuem trajetórias pessoais muito diferentes entre si, como se pode ver no quadro 18 :

Quadro 18: Experiências anteriores dos voluntários entrevistados

\begin{tabular}{|c|c|c|}
\hline Voluntário & Experiências Anteriores & Tipos \\
\hline 1 & $\begin{array}{c}\text { Nunca havia sido voluntário em } \\
\text { organização }\end{array}$ & Aulas de tricô \\
\hline 2 & Em outra organização espírita & $\begin{array}{c}\text { Campanha do quilo } \\
\text { Costura para o enxoval }\end{array}$ \\
\hline 3 & Sim, na mesma organização & $\begin{array}{c}\text { Visita a colônia de hansenianos } \\
\text { Visita à FEBEM } \\
\text { Limpeza da creche } \\
\text { Cuidados com as crianças } \\
\text { Monitora } \\
\text { Supervisora } \\
\text { Aulas de crochê } \\
\text { Aulas de tricô } \\
\text { Enxoval }\end{array}$ \\
\hline 4 & Nunca havia sido voluntário & Professor de costura \\
\hline 5 & Sim, na mesma organização & $\begin{array}{c}\text { Visita a colônia de hansenianos } \\
\text { Visita à FEBEM } \\
\text { Compras e controle de estoque do enxoval }\end{array}$ \\
\hline
\end{tabular}

(continua) 
(continuação)

\begin{tabular}{|c|c|c|}
\hline Voluntário & Experiências Anteriores & Tipos \\
\hline 6 & $\begin{array}{l}\text { Sim, em diversas organizações } \\
\text { espíritas ou não }\end{array}$ & $\begin{array}{c}\text { Visita a Asilos e Hospitais pela Sociedade São Vicente } \\
\text { de Paula } \\
\text { Visitas à Fundação Dr.João de Freitas } \\
\text { Visita a um Sanatório de Tuberculosos } \\
\text { Sócio-Fundador da Sociedade de Amigos dos Lázaros } \\
\text { Plantonista do Centro de Valorização da Vida - } \\
\text { Samaritanos } \\
\text { Coordenador do Centro de Valorização da Vida em } \\
\text { Minas Gerais } \\
\text { Voluntário na Fundação Nosso Lar (Creche) } \\
\text { Superintendente da Creche Futuro } \\
\text { Assessor Financeiro da Creche Futuro }\end{array}$ \\
\hline 7 & Nunca havia sido voluntária & Aulas de Bordado \\
\hline 8 & $\begin{array}{l}\text { Sim, em outras organizações } \\
\text { espíritas }\end{array}$ & $\begin{array}{c}\text { Confecção de cesta básica } \\
\text { Cuidados de crianças em creche } \\
\text { Sindicância } \\
\text { Campanha do quilo } \\
\text { Aulas de crochê e tricô }\end{array}$ \\
\hline
\end{tabular}

Fonte: História de vida dos voluntários

Dos voluntários estudados, três são de "primeira geração", e começaram a voluntariar-se na terceira idade; três são "imigrantes", mas apenas um deles havia participado como voluntário de organizações não espíritas e dois são "migrantes", tendo-se iniciado em outros territórios (vizinhos) e migrado para este, ou se voluntariado em dois ou mais territórios simultaneamente.

Pelo menos nesse território a idéia de "universo fechado", discutida por Giumbelli (1998), é evidente em meio aos voluntários, o que se confirmará posteriormente.

Este trânsito e deslocamento de voluntários por territórios de influência, seu vínculo com o movimento subjacente à cultura organizacional e se são voluntários pela primeira vez, ou não, são categorias possivelmente relevantes para o estudo e a compreensão de outras organizações de Terceiro Setor.

Um aspecto observado, com relação ao relato de experiências do indivíduo como voluntário, é a associação feita pelos entrevistados entre a expressão "trabalho 
voluntário" e a noção de serviço social. Alguns dos voluntários já ocuparam cargos de gestão na mantenedora, que não são remunerados, mas não relataram estas experiências como trabalho voluntário. Um dos voluntários, quando questionado sobre trabalho voluntário não assistencial, afirmou:

Eu não sei se eu poderia relacionar nosso trabalho na doutrina. Bom, aí eu nem gostaria de falar porque o que a gente recebe em troca é muito maior do que a gente dá. (Voluntário seis)

E passou a narrar situações de auxílio pessoal, mas não se referiu a nenhum dos cargos de direção que exerceu na mantenedora e nos outros grupos onde esteve. Esse fenômeno se repetiu em todas as entrevistas. Seria algo próprio da organização, do universo espírita ou do Terceiro Setor em geral?

10.3 Processo de atração e socialização na Creche Futuro.

Como se poderá ver abaixo, o processo de socialização é calcado em certo personalismo, que lhe dá certa conformação. A reunião de estudos na mantenedora é a principal fonte de recrutamento dos voluntários, que são atraídos por convites gerais feitos na reunião ou por convites pessoais. Quase todos se recordam da pessoa que os abordou e os convidou e há um grande destaque para o líder do território.

Os relatos, de uma forma geral, não fazem menção a processos de socialização. 
Quadro 19: Processo de socialização dos voluntários entrevistados

\begin{tabular}{c|c|c}
\hline Voluntário & $\begin{array}{c}\text { Como foi atraído? } \\
\text { Convite na reunião que } \\
\text { freqüenta }\end{array}$ & $\begin{array}{r}\text { Pãocesse encontram em seu relato menções a ele. A } \\
\text { socialização organizacional se deu na mantenedora. }\end{array}$ \\
\hline 1 & $\begin{array}{c}\text { Convite da dirigente } \\
\text { Não se encontram em seu relato menções a ele. A } \\
\text { socialização organizacional se deu na mantenedora. }\end{array}$ \\
\hline 3 & Convite da dirigente & Faz menção à pessoa que a socializou, mas não ao processo. \\
\hline 4 & Convite da dirigente & Não se encontram em seu relato menções a ele. \\
\hline 5 & Convite da dirigente & Não se encontram menções a ele \\
\hline 7 & Convite do fundador & Não se encontram menços a ele. \\
\hline 8 & $\begin{array}{c}\text { Convite na reunião da } \\
\text { dirigente }\end{array}$ & Não se encontram menções a ele \\
\hline
\end{tabular}

Fonte: História de vida dos voluntários

Como se pode ver, a principal fonte de recrutamento desses voluntários foi o convite pessoal do líder do território, a segunda fonte foi um convite impessoal feito na reunião do líder, a seguir vem um convite pessoal de um dos fundadores e um convite pessoal feito por outro voluntário.

Esta forma de funcionamento, embora não seja obrigatória nem regimental, é uma prática que se encontra associada ao controle do caráter espírita da organização e à manutenção do vínculo carismático entre líder e voluntários.

A diretoria acolheu bem a proposta feita em uma das reuniões de se recrutarem voluntários na comunidade em que a creche se encontra, mas passados dois anos a idéia não foi operacionalizada por ninguém.

Este mecanismo se ajusta bem às análises de Cavalcanti (1983), porque o recrutamento de espíritas-colaboradores ou pelo menos de espíritas-freqüentadores já assegura o compartilhamento e a aceitação de alguns dos valores que permeiam a atividade sob a forma de pressupostos básicos e reduz (embora não elimine) os conflitos. 
10.4 Significado de sua experiência ante um quadro de tendências motivacionais

A análise das entrevistas mostra diferentes arranjos motivacionais depreendidos do discurso dos sujeitos. Estes exemplificam sua gratificação no trabalho como voluntários, ora com base no recebimento de afeto e camaradagem, ora apresentando o resultado do seu trabalho, ora dando mostras de ter construído, nestas atividades, uma auto-imagem valorizada. As menores incidências foram as que mostraram alguma associação entre a satisfação no trabalho e a aquisição de informações, ou desenvolvimento de novas habilidades e competências ou a influência de outras pessoas da instituição para a consecução de objetivos (exercício do poder).

Não se inseriram no quadro, em decorrência das características do objeto de estudo (trabalho voluntário), as necessidades fisiológicas e as de contato com objetos do mundo sensorial, embora, na análise das entrevistas, o avaliador pudesse considerá-las, caso o sujeito as destacasse.

A tabela seguinte apresenta a cotação do significado das respostas pelo pesquisador. Não há qualquer sentido em se somar o número de respostas dos voluntários, uma vez que os padrões discursivos, a consciência de si mesmos e a disposição para falar de assuntos pessoais variaram bastante de sujeito para sujeito. 
Quadro 20: Tendências motivacionais dos voluntários

\begin{tabular}{cccccc}
\hline Voluntário & TCIa & TCIp & TInf & TReal & TCInt \\
1 & 0 & 0 & 0 & $\mathbf{2}$ & $\mathbf{3}$ \\
2 & $\mathbf{2}$ & 0 & 0 & 0 & $\mathbf{1}$ \\
3 & $\mathbf{2}$ & 0 & 0 & 0 & $\mathbf{1}$ \\
4 & 0 & 0 & 0 & $\mathbf{1 2}$ & $\mathbf{9}$ \\
5 & 0 & 0 & 0 & 0 & $\mathbf{6}$ \\
6 & $\mathbf{8}$ & 0 & $\mathbf{2}$ & $\mathbf{1}$ & $\mathbf{3}$ \\
7 & $\mathbf{3}$ & 0 & 0 & $\mathbf{4}$ & $\mathbf{3}$ \\
8 & $\mathbf{1}$ & 0 & 0 & 0 & $\mathbf{4}$ \\
\hline
\end{tabular}

Fonte: História de vida dos voluntários

$\mathrm{O}$ relato de situações que sugerem a tendência a estabelecer contatos pessoais com trocas afetivas (geralmente positivas) no trabalho voluntário foi encontrado nas entrevistas de cinco sujeitos. Eles valorizam, ou sentem-se gratificados ou ainda apresentam, como exemplo de gratificação, situações como a que se transcreve abaixo:

E, muitas vezes, as crianças no pátio até hoje nos chamam. Na época era tio, né, hoje é vovô “- oh vovô, deixa eu te dar um beijo!" Então eu acho que não há dinheiro nenhum que pague uma satisfação dessas (...) E, outro dia eu estive aqui mais cedo fazendo ponto e fui embora. Quando eu voltei à tarde, uma das moças falou assim "Seu Jonas, eu encontrei Cá́que ali murcho, chorando. Eu perguntei o que foi ele falou "é porque eu num vi o vovô Jonas" Então eu mandei buscá-lo na sala. Então ele vem, abraça comigo e toda vez que eu tô aqui. Então, eu acho que num há dinheiro nenhum que retribua o trabalho. (Voluntário seis)

Os relatos de tendência à realização mostram situações em que atingir o objetivo formal da atividade é fonte de gratificação, e em que o sujeito se mostra satisfeito por ter conseguido realizar este objetivo ou frustrado quando algum acontecimento o impede de fazê-lo. O relato abaixo é de um dos instrutores de oficina:

A gente sempre quer ter resultado, né. Mas como a vida num é assim, né. Eu pelo menos esperava que elas se esforçassem mais, tivessem mais desempenho e tudo. Ou que aprendessem mais rápido, sei lá. (...) você sabe que quando elas fazem alguma coisa que realmente você fala "nó, tá 
aprendendo" que coisa boa. A gente até arrepia, né. Há pouco tempo uma das alunas fez um casaquinho mesmo, fez lá um dia , mas eu achei tão bonitinho, que eu falei "graças a Deus está conseguindo alguma coisa". Mas por enquanto essa parte ainda está meio fraca. (risos) (Voluntário 4)

Os relatos que sugerem a gratificação do sujeito a partir de uma construção, ou melhor, de uma reconstrução da identidade, que tem por base os significados das atividades e do trabalho voluntário, foram muitos e estão presentes no discurso de todos os voluntários observados. O voluntário quatro, por exemplo, explica sua inserção no trabalho voluntário como a inauguração de uma nova fase de sua vida, que ocorreu quando ele já havia atingido o sucesso profissional, e os filhos já haviam se tornado autônomos. Ele procurou no espaço que a organização lhe ofereceu (instrutor de corte e costura) a possibilidade de formar profissionais capazes de autonomia e sucesso, assim como ele próprio, como se vê abaixo:

...então eu falei que gostaria de fazer alguma coisa, alguma doação, como eu tô querendo parar passar pra outras pessoas aquilo que eu aprendi, né, que é uma maneira boa de você ganhar dinheiro também, né, um trabalho muito bom. (...)então o que eu queria passar quando eu vim pra aqui foi ensinar elas a fazer tirar uma medida, fazer uma modelagem e fazer a roupa sem precisar de uma peça de um modelo, uma peça piloto. Se a cliente chega e escolhe o que ela quer num manequim numa revista, ela tem condição de fazer nem que seja gorda, magra, usando seda, linho, malha, qualquer coisa, né. Porque eu acho que isso é que é ser uma costureira de verdade. (Voluntário quatro)

O voluntário cinco,ou seja, a voluntária cinco mostra como se sente valorizada em uma certa atividade que depende da respeitabilidade e confiança do grupo, para ser efetuada. Ela parece que não tinha esta posição em sua família quando se vinculou ao grupo, e que não logrou obter essa valorização em outra atividade voluntária.

Esse enxovalzinho, eu sempre falo, sabe, é a minha vida. Se me tirarem, me tira um pedaço, sabe. Teve uma vez que precisou de professora de crochê e me tirou. Ah, eu passava, via os enxovalzinho assim, ensinando crochê, mas aqui dentro tava doendo, sabe. (...) Eu acho que é uma responsabilidade muito grande. Eu fico feliz da Dona G. ${ }^{110}$ confiar em mim, das pessoas me deixam comprar o que eu quero dentro daquilo que precisa. Ela me deixa à

${ }^{110}$ Ela refere-se à coordenadora da atividade. 
vontade. Eu sinto feliz com isso. Sou muito feliz. Agora nós temos que controlar até o fim do ano porque nós não vamos ter dinheiro tão cedo. Então tudo isso passa por mim. Acho que eu gosto muito disso, sabe. (Voluntário cinco)

Os relatos que poderiam ser associados a uma tendência à informação não apresentam aquisição de conceitos e teorias, mas, quando muito, o desenvolvimento de habilidades relacionadas à convivência. A única exceção foi encontrada na entrevista com o voluntário seis, que assim se exprime:

Tivemos a oportunidade de ir a São Paulo num encontro dos CVVs do Brasil todo, da Argentina, do Uruguai, do Paraguai e lá aprendemos muito com os companheiros. (Voluntário seis)

Ele não se estendeu na explicação de que tipo de conhecimentos obteve. Este mesmo voluntário refere-se, em um momento posterior do seu discurso, a um aprendizado que entremeia o aprendizado social e o aprendizado moral:

Mas com a construção da Creche Futuro, também fomos escolhidos pela casa para ser o primeiro superintendente aqui onde também tivemos a oportunidade de, como voluntários, com as companheiras que deixavam seu trabalho no lar, às vezes deixavam seus filhos para virem se dedicar aos filhos dos outros. (Voluntário seis)

10.5 Schemata identificados no discurso dos voluntários.

Os schemata foram identificados no discurso dos voluntários em duas situações distintas.

Na primeira, eles são usados como justificação de ações ou escolhas do sujeito, geralmente desassociados de uma experiência pessoal que lhes confirme o sentido.

Na segunda ocorre o oposto. O schemata é corroborado com a narrativa de uma experiência pessoal. De uma forma geral, eles foram enunciados pelos sujeitos em sentenças na forma imperativa ou em forma de máximas aplicáveis às pessoas em geral, às vezes alternando bruscamente o tom subjetivo do discurso. 
Identificaram-se os principais schemata utilizados pelos voluntários. A maioria deles está articulada com o ethos e a visão de mundo espírita, uns poucos são estranhos a eles.

Quadro 21 Principais schemata encontrados no discurso dos voluntários

\begin{tabular}{l|c|c|c}
\hline \multicolumn{1}{c|}{ Schemata } & Citações & Voluntários & $\begin{array}{c}\text { Associado ao } \\
\text { Ethos Espírita? }\end{array}$ \\
\hline $\begin{array}{l}\text { "É necessário fazer algum trabalho em favor do } \\
\text { próximo". }\end{array}$ & 3 & $1,3,7$ & Sim \\
\hline $\begin{array}{l}\text { "Se cada um fizer um pouco é possível fazer algo } \\
\text { grande". }\end{array}$ & 1 & 2 & Sim \\
$\begin{array}{l}\text { "O primeiro beneficiado pelo trabalho é o próprio } \\
\text { trabalhador". }\end{array}$ & 5 & $2,6,7$ & Sim \\
\hline "Dedicar-se ao próximo traz alegria". & 1 & 6 & Sim \\
\hline "O trabalho é uma terapia". & 3 & 2,3 & Sim \\
\hline "Recebe-se mais com o trabalho do que se dá". & 1 & 6 & Sim \\
\hline "Deve-se fazer o bem sem esperar retribuição". & 2 & 8 & Sim \\
\hline "Há homens de bem em todos os credos". & 1 & 6 & Sim \\
\hline "A mulher moderna precisa ser independente". & 1 & 4 & Não \\
\hline "Não se pode viver sem Deus". & 1 & 7 & Não \\
\hline
\end{tabular}

Fonte: História de vida dos voluntários

Estes schemata, como já foi dito, permitem a organização da experiência segundo preceitos coletivos (da esfera do movimento espírita ou da sociedade), ou justificam as ações dos voluntários dentro da organização.

Os sete primeiros schemata reforçam o imperativo ético espírita da ação humanitária. Têm, portanto, um papel de justificar o ato de ser voluntário em favor de um próximo e de focalizar a percepção do sujeito para os benefícios desta ação. Seguramente são esquemas sociais, como o definiu McClelland.

Enquanto quadro explicativo do significado do trabalho voluntário, estes valores não se prestam a fomentar uma prática de planejamento, de avaliação e de verificação de resultados externos, a lógica instrumental, que se encontra presente de forma geral na administração. Enquanto terapia, fonte de benefícios e de alegria para o trabalhador voluntário, o trabalho tem seu foco voltado para quem o realiza, e não para quem seria seu objeto. 
$\mathrm{O}$ oitavo reforça o valor espírita do respeito às convicções sinceras. $\mathrm{O}$ nono justifica o caráter promocional da obra social a que esta voluntária se engajou e organiza a sua experiência pessoal (ela própria é uma mulher independente, como deveriam ser todas as mulheres modernas), e o último justifica o retorno do voluntário à religião, após um período de afastamento e de dor.

A análise dos schemata corrobora a idéia de que a análise cultural no Terceiro Setor não pode prescindir da análise do ethos e da visão de mundo, no nível do movimento religioso, político ou social ao qual a organização está ligada, sob o risco de não-compreensão da lógica dos membros.

10.6 O caráter paradoxal do trabalho voluntário: satisfação, desligamento e sofrimento

A análise da motivação mostrou situações de gratificação de diversas ordens, propiciadas pelo trabalho voluntário. Relações afetuosas, valorização da auto-imagem, aprendizagem social, realização de projetos e aspirações pessoais são alguns dos ganhos acenados pelos sujeitos entrevistados. Entretanto, não se pode reduzir o trabalho voluntário aos seus aspectos gratificantes. Ele possui também outras dimensões.

10.6.1 O trabalho voluntário como desligamento do sofrimento

Uma primeira dimensão é a possibilidade de o trabalho voluntário servir ao sujeito como uma atividade na qual ocorre um desligamento temporário da tensão e da ansiedade gerada em outras esferas da vida pessoal, como a família. 
Há um relato de episódios de depressão da filha e de uso de drogas seguido de roubo e violência por parte do neto. Não se identificará o número dos voluntários por razões éticas, para preservar a possibilidade de algum leitor mais próximo identificá-los.

\begin{abstract}
...às vezes, eu tenho sérios problemas com a família. Seríssimo, você nem imagina. (...) Semana passada, estou te dando uma idéia, segunda-feira feira passada, eu vim...eu...eu vim mesmo porque eu falei gente, eu preciso mesmo de...de fazer mesmo alguma coisa por mim, nem foi por ela não. Porque eu tinha tido uma coisa horrível, ele tinha tirado muita coisa. (...) Então quando eu cheguei aqui aí uma vem e conta: - "ah, isso aqui está certo, isso aqui eu errei", quer dizer, sabe? Então eu acho que isso é satisfação. - Voluntário
\end{abstract}

Outro voluntário faz uma menção rápida à relação entre o seu trabalho e a uma possível "depressão"111:

Você chega aqui, você esquece de tudo. Esse período que eu agora que eu atravessei e...uma conversa num dá tempo de você pensar em depressão, em coisas ruins, nada, nada, nada. Você tem é que ver, trabalhar em conjunto, ver, às vezes, as dificuldades da companheira que vem de longe pra ajudar, né? - Voluntário

Um terceiro voluntário narrou espontaneamente e, com detalhes, a sua perturbação emocional após a perda do filho e a suspeita de ele ter sido assassinado pela nora. Ele narrou seu afastamento da Igreja Católica e sua inserção no centro espírita, em busca de significado para esta experiência, referindo-se, a seguir, ao trabalho voluntário da seguinte forma:

Então, eu resolvi ajudar de alguma forma. Com aquilo que eu sei fazer eu ensino as meninas a (omitido para evitar a identificação do sujeito). Então é através dessa minha experiência de vida é que eu vejo que eu não estou ajudando as meninas, o pessoal. Eu estou ajudando mais a mim mesma. Porque, com isso, eu estou tentando melhorar o aprendizado de paciência, um aprendizado mais de amor, de carinho. - Voluntário

A narrativa não permite caracterizar este desligamento como fuga, uma vez que não há qualquer associação entre a realização do trabalho voluntário e o ato de

\footnotetext{
${ }^{111} \mathrm{O}$ termo não está sendo empregado como categoria psicopatológica, podendo referir-se a uma tristeza ou outra emoção semelhante.
} 
evitar empreender ações para solucionar o problema. A existência de "voluntáriosfugitivos" continua sendo uma possibilidade, mas não foi constatada no presente estudo.

10.6.2 O trabalho voluntário como fonte de sofrimento psíquico

Uma segunda dimensão encontrada são os sofrimentos relatados pelos voluntários. O termo sofrimento é empregado a partir dos estudos da psicopatologia do trabalho dejouriana ${ }^{112}$ que o utilizou para evitar confusão com a noção de doença mental. A metodologia adotada permite identificar em algumas entrevistas a associação feita pelo sujeito entre o seu sofrimento e o trabalho voluntário, como se pode ver abaixo:

Eu acho que é o despotismo. Porque tem umas que gostam realmente de aparecer mais do que as outras e você vê que criam-se situações até desagradáveis. Eu já vi até choro, muito choro, muito choro. Mas como eu sei que se eu morrer não vou levar nem um alfinete, aí eu vou levando. Voluntário

Outro voluntário teve sua auto-imagem afetada quando ocorreu um roubo de objetos que ele considerou ser por culpa de sua negligência.

Foi aonde eu errei. Então o sentimento de culpa foi muito grande. Eu sofri com isso. E fiquei achando que eu que errei. E tive que falar para Dona G. Voluntário

O sentimento deste voluntário não foi agravado pelo dirigente, que disse já ter visto e que havia "morrido o assunto".

Outro voluntário relatou o desenvolvimento de uma possível "doença psicossomática" ou de somatizações, associando-as às preocupações e conflitos no trabalho voluntário.

E de modo que nós tivemos muitos problemas e que, para não ferir um companheiro, nós ficávamos às vezes, remoendo aquele problema e isso nos

${ }^{112}$ DEJOURS, 1992, DEJOURS, 1997, DEJOURS, 1993, DEJOURS ET AL., 1993, DEJOURS, 1994. 
levou a um destrambelhamento do organismo, pressão alta que os médicos pesquisaram, pesquisaram e não encontraram a causa. - Voluntário

Este voluntário continua a narrativa, explicando que o médico, ante a normalidade dos exames, questionou-o sobre outros aspectos que ele tivesse esquecido de falar, ao que ele passou a contar os problemas de gestão que enfrentava na instituição, como o de mães que esqueciam seus filhos na creche e o da cobrança de companheiros de direção.

Outra narrativa encontrada é referente à ansiedade que uma voluntária sente ao realizar seu trabalho, por não conseguir atender a todos com prontidão. Não há como sugerir que o trabalho voluntário seja a fonte dessa ansiedade, que possivelmente está na história pessoal dela.

... eu fico aflita para que aquela aprenda para poder passar para a outra, que a outra também já está esperando. Então eu fico "calma, gente, calma". Mas aquela "calma, gente" é para mim mesma. Isto às vezes esgota um pouco, mas tem a sua recompensa. - Voluntário

Este mesmo voluntário se queixa da incompreensão dos alunos com suas exigências de aperfeiçoamento, o que aponta uma certa frustração, que o sujeito justifica e procura minimizar (mas a relata). Ele explica que, por exigir que o aluno aprendesse a fazer o bordado com avesso perfeito, este aluno abandonou o curso.

Aí sai falando da gente, que nós somos isso, que nós somos aquilo. Porque eles não acham que nós somos espíritas, eles acham que nós somos santos. Voluntário

Outro relato de sofrimento encontrado foi de impotência ante a relação com a miséria e os limites da instituição. O voluntário assim se exprime:

Muitos deles também era necessidade mesmo, que moravam naqueles bairros mais... passava esgoto na porta. Tinha dias que não tinha condições mais de levar para a creche, não tinha vaga mais. Dava uma tristeza na gente de não poder mais ajudar, sabe? - Voluntário

A população nem sempre recebe bem os pedidos de campanha e hostiliza os voluntários. 
Tem dias que tem gente que te responde mal, que nem abre a porta, mas você vai numa casa humilde que te dá um monte de coisa e você tem vontade de pegar sua cesta e entregar para ela.

10.6.3 Mecanismos de defesa empregados pelos voluntários contra o sofrimento.

Uma vez que existem sofrimentos associados ao trabalho, que tipos de mecanismos de defesa são empregados pelos voluntários contra estes sofrimentos?

A psicopatologia do trabalho emprega o termo defesa, oriundo da psicanálise e reconstruído por esta nova área, para a análise de estratégias construídas individual ou coletivamente $^{113}$ pelos trabalhadores para lidar com os efeitos do sofrimento psíquico observado em associação com a organização do trabalho.

O mais óbvio é o afastamento do trabalho voluntário, que não pode ser diretamente observado por causa da metodologia adotada. O tipo de vínculo legal permite que o voluntário deixe de realizar a sua atividade no momento em que quiser. Houve alguns poucos relatos de afastamentos temporários associados aos aborrecimentos e frustrações no trabalho, mas esses voluntários retornaram após um tempo e justificam:

Parei, parei um ano. Depois eu voltei de novo. A Dona G. ligou e eu fiquei pensando assim... "ah... a gente também tem que ter um pouquinho de paciência, né. Passar uma borracha nas coisas de vez em quando. Ser mais tolerante, porque do mesmo jeito que elas reclamam eu também não gostei. Voluntário

Como se observa, afastar-se por um tempo faz com que o sujeito possa dar um novo significado aos eventos frustrantes e retomar suas atividades posteriormente.

Outro mecanismo observado foi o uso de contrapartidas. Após referir-se a um evento frustrante ou sofrido, o voluntário relata outros eventos gratificantes, que têm o efeito de mostrar ao seu interlocutor (e a si mesmo?) que, apesar dos problemas, vale a

${ }^{113}$ Cf. DEJOURS (1992, p. 27-47), DEJOURS (1993, p. 149-173). 
pena voluntariar-se. No mesmo período em que relata seu sofrimento, um voluntário descreve quatro experiências de gratificação intensas e reafirma:

Quem nos ouve e quem ler o trabalho do Jáder e possa ouvir o que estamos dizendo, paga a pena ser voluntário, é muito compensador - Voluntário

Um terceiro mecanismo de defesa encontrado foi de o voluntário evitar falar de eventos desagradáveis. Algumas frases ditas eram referências a eventos que não foram narrados ou que só aparecerão na narrativa muito depois, quando já existiria uma maior confiança no interlocutor, ou um grau maior de intimidade do discurso.

Bom, há pouco tempo teve aí umas complicações. Sempre tem, né? Eu fiquei muito chateada, tive que tomar Floral, sabe? Porque acontecem umas coisas que a gente fica muito abalada mesmo. Eu prefiro não falar sobre isso. Tirando isso, nunca aconteceu nada entre as companheiras. Voluntário

Apesar de a literatura referir-se ao uso do humor como mecanismo para lidar com o conflito e reduzir a tensão, as entrevistas não apresentaram material para isto. Na observação de campo, há eventos que sugerem esse mecanismo, mas ele deve ser mais bem analisado em um estudo futuro.

Observou-se no grupo a existência de idealização do líder carismático. Não se pode afirmar que esse mecanismo funcione como uma defesa contra o sofrimento, mas traz uma contribuição na construção da auto-imagem da pessoa ("eu trabalho com alguém que é admirável"). Esse mecanismo de defesa possibilita um efeito de adesão da pessoa ao grupo mais que à organização.

Então por isso tudo o que ela fala para mim é uma ordem. E se sair da ordem dela, dá tudo errado. Já aconteceu comigo de dar tudo errado por eu achar que eu podia agir sozinha. - Voluntário

Diversos assuntos neste capítulo merecem novos estudos. O que sugerem os estudos sobre o papel do voluntariado como valor na família é que o exemplo familiar não é determinante, dados os diversos voluntários de "primeira geração" encontrados e que, mesmo onde algum familiar tinha uma atitude contrária à participação do sujeito 
como voluntário, isto não se constituiu empecilho suficientemente significativo para impedir seu vínculo e seu comprometimento. A entrevista com o voluntário seis e sua trajetória, nitidamente diferenciada dos demais, faz interrogar sobre a função dos heróis valorizados pelos sujeitos (no caso a sua mãe é percebida como tal) nos quais o serviço à comunidade ou ao próximo é um traço distintivo. A entrevista com alguns dos demais voluntários, que idealizaram o líder do território, tem uma função semelhante à de construção de um herói vivo, que está associado a uma função de vínculo e comprometimento destes com o trabalho voluntário que realizam.

Uma vez proposta esta função de vinculação exercida pelo herói, questionase se ela seria similar à função que a remuneração exerce no trabalho remunerado. Essa questão certamente transcende o alcance deste estudo. Outro item de pesquisa que se abre para o futuro é se o estudo dos heróis percebidos pelos sujeitos no processo de seleção de voluntários seria um preditor de comprometimento com o trabalho voluntário.

$\mathrm{Na}$ presente organização, os voluntários manifestaram, ao relatarem suas histórias, a tendência aos contatos interpessoais, visando à afiliação e à troca afetiva, a tendência à consistência interna e, com uma freqüência menor, a tendência à realização. Não há relatos associados à tendência aos contatos interpessoais, visando ao poder, nem de tendência à informação. Poder-se-ia afirmar, portanto, que se trata de um espaço organizacional que desvaloriza as manifestações das duas últimas tendências, e que por isto faz uma seleção natural das pessoas, que se sentem gratificadas com o exercício das duas primeiras? 


\title{
11. DISCUSSÃO DOS RESULTADOS: EM BUSCA DE UMA ESPECIFICIDADE DAS ORGANIZAÇÕES DE TERCEIRO SETOR
}

\author{
“Mas, meu Deus, como isto é bonito! Que lugar bonito p'r'a gente deitar no \\ chão e se acabar!..." - João Guimarães Rosa
}

A história da Creche Futuro é a história da perda e reconstrução de um projeto de ação social, em que o projeto do fundador foi sendo alterado para atender a três grandes problemas que ele não contemplava: a autonomia financeira, o superdimensionamento das atividades voluntárias e o não-compartilhamento dos objetivos propostos, pelos membros. O fundador, portanto, tornou-se um "herói esquecido", pai de um projeto original e instigante que não se tornou um projeto institucional partilhado pelos seus executores.

O caso em estudo mostra um conflito existente entre um projeto realizado aos moldes de uma empresa (grupos-tarefa, planejamento institucional, estabelecimento de metas, institucionalização de comissão de avaliação, etc.) e uma cultura de trabalho desenvolvida anteriormente e partilhada pelos membros de um movimento religioso que concebe o trabalho social como uma experiência de auto-aprimoramento, de fortalecimento dos laços entre os membros de um mesmo grupo, pelo qual não se deve ter a preocupação com resultados. Com isto, questiona-se a abordagem de muitos autores de Administração que percebem o Terceiro Setor como um setor emergente que desconhece as técnicas empresariais e que necessita de um profissional que as ensine e implante.

Este estudo corrobora a idéia de que o "Terceiro Setor" é regido por lógicas alternativas à lógica instrumental da administração, as quais devem ser entendidas e 
discutidas com seus membros antes de se lhes propor um projeto de gestão mais empresarial, sob o risco de se verem frustrados seus esforços. Faz sentido propor-se uma administração de organizações do Terceiro Setor que seja construída não apenas com base nos impactos da legislação própria dessas organizações, mas que considere a cultura e a motivação dos seus atores-sujeitos.

Esta tese propõe uma nova perspectiva para a construção feita por técnicos do Terceiro Setor que desejam opor a lógica da caridade à lógica da promoção social, ao entender que se trata de duas esferas autônomas e não contraditórias entre si. A lógica da caridade pertence à esfera do indivíduo e a lógica da promoção social à esfera da organização ou do grupo. Nada impede que estas duas esferas sejam complementares, pois sua oposição ou complementação encontram-se inscritas na cultura da organização, seja como valor, seja como pressuposto básico.

Em resposta à primeira questão originalmente proposta, observou-se que a motivação dos voluntários estudados se deu concomitante à gratificação de três grandes tendências: contatos interpessoais, visando à afiliação e às trocas afetivas e consistência interna com enriquecimento da auto-imagem, em um primeiro plano e à realização em um segundo plano. Este resultado, entretanto, não é passível de generalização, posto que a observação participante e a análise de documentos mostram a existência de contatos interpessoais que visam ao poder, na organização. Observou-se também que a tendência à informação tem o seu papel, mas neste caso (e talvez no caso das organizações espíritas em geral) ele seja ocupado nos outros espaços organizacionais não reconhecidos pelos interlocutores como espaço de voluntariado, especialmente o chamado "estudo" pelos antropólogos. 
Observou-se também que o trabalho voluntário desenvolveu-se melhor nas equipes de trabalho e que os voluntários que passaram a atuar isoladamente tenderam a afastar-se com o tempo. As equipes de trabalho parecem permitir a continuidade da atividade ante a situação de afastamento, e a diversidade de possíveis tarefas dá aos sujeitos uma possibilidade de escolhas de atividades, necessárias para que haja acomodação entre a demanda motivacional subjetiva e o trabalho executado.

Na referida organização a motivação para o trabalho voluntário está ligada à idealização do líder carismático e dos heróis da organização, que parecem ter um papel de enriquecedores da auto-imagem dos voluntários, razão por que as tendências à consistência interna e a estabelecer contatos interpessoais afetivos se destacaram. Novos estudos precisam ser realizados para que essa observação seja devidamente generalizada.

O estudo da motivação revelou algumas informações sobre o sofrimento dos voluntários. Como também é fonte de sofrimento, o trabalho voluntário traz em seu contexto o surgimento de mecanismos de defesa individuais e coletivos. Nesse caso, identificaram-se vários mecanismos: o afastamento temporário ou definitivo da tarefa, equipe ou organização, o uso de contrapartidas, o uso do humor, evitar-se falar de eventos desagradáveis e a idealização do líder.

As entrevistas puderam indicar a existência de diferentes formas de sofrimento, mas não conseguiram avaliar sua intensidade e a sua influência em quadros de transtornos psiquiátricos e psicossomáticos. Duas questões de pesquisa, ainda em aberto, envolvem a identificação da relação entre sofrimento e doença mental, e entre sofrimento e doenças psicossomáticas. Uma vez que um trabalho sem sofrimento parece 
ser uma utopia, como reorganizar o trabalho de forma a minimizar esse sofrimento observado nos voluntários?

Como fonte de prazer e gratificação, o trabalho voluntário oferece não só a possibilidade de construção de grupos afiliativos e afetuosos, como a reconstrução enriquecida da auto-imagem do voluntário e a possibilidade de realização de projetos pessoais, desde que articulados ou com poucos pontos de conflito com as propostas e com o "modus operandi" da equipe à qual o voluntário se filiou.

O estudo da motivação dos voluntários permitiu que se observasse a existência do "desligamento temporário do sofrimento" originado em outros grupos sociais, como a família e o trabalho. Sob essa ótica, o trabalho voluntário pode ser estudado como um fator adicional de proteção ao estresse.

O modelo de pesquisa de motivação mostrou-se rico para a apreensão das tendências dos sujeitos, sem que haja qualquer pretensão de se chegar à exaustão do fenômeno, mas a metodologia empregada (história de vida como voluntário) não se mostrou adequada para a avaliação do modelo de dinâmica motivacional. Esta ainda aguarda novos estudos para ser mais bem discutida.

A segunda questão da pesquisa indagava os elementos da cultura que deveriam ser considerados para o entendimento das organizações de Terceiro Setor.

Este estudo mostrou que a adaptação do modelo de Fleury permitiu a compreensão da lógica própria da organização. Este autor propõe, originalmente, que se estude tanto a história da organização, com ênfase no fundador e nas crises, quanto o processo de socialização de novos membros, as políticas de gestão de pessoas, os processos de comunicação assim como organização do processo de trabalho. 
A adaptação desse modelo demandou a análise de novo nível da cultura, intermediário aos níveis societário e organizacional, e característico da maioria das organizações do Terceiro Setor: o dos movimentos políticos, religiosos ou sociais. As pessoas são, ao mesmo tempo, membros de organizações e da sociedade e podem se identificar com esses movimentos, reconstruindo suas identidades sob a influência dos valores, crenças e pressupostos básicos partilhados em nível de movimento.

Para a análise deste novo nível, foram usadas categorias analíticas originalmente utilizadas por Clifford Geertz no estudo de sociedades, ethos e visão de mundo. $\mathrm{O}$ estudo da obra social espírita colocou esse modelo em contato com algumas categorias antropológicas e administrativas, que precisariam ser mais bem analisadas em outros segmentos do Terceiro Setor, mas que possibilitam também a apreensão de sua lógica: a abertura da organização a outras esferas da sociedade, seu processo de tomada de decisões, o "sonho ou aspiração" do(s) fundador(es) ao criar uma OTS e as formas encontradas de exercício das lideranças.

O entendimento da lógica da Creche Futuro, o que se procurou fazer a partir de uma perspectiva culturalista, explicou ex post facto os porquês da resistência em implantarem-se certas técnicas de gestão que, em tese, tornariam a organização, em tese, mais eficaz e efetiva.

A análise dos schemata de McClelland revelou-se um ponto de conexão entre o individual e o coletivo. No presente estudo, os schemata revelaram elementos do ethos do movimento religioso ou da sociedade, apreendidos e empregados pelos sujeitos como justificativa de suas ações e experiências. Esses schemata são claras referências a algo externo à experiência singular, mas que tem atuação clara na construção do sentido e na apreensão da realidade social. 
Tais constatações afetam o campo de estudos, demandando novos desafios e perspectivas.

$\mathrm{O}$ primeiro e mais evidente deles diz respeito à generalização do modelo teórico proposto. Para a avaliação da sua contribuição ao entendimento do Terceiro Setor, novos estudos em outras organizações e, especialmente, em organizações cujo movimento de base é político ou social, assim como em organizações que atuem em nível político, são fundamentais.

A questão das alianças estratégicas com o setor público é outro tema emergente, e este trabalho sugere que não só se estudem propostas de interação menos leoninas entre o poder público e as OTS, bem como sejam feitos estudos de legislação e administração pública, visando à simplificação das rotinas burocráticas e de credenciamento, assim como da possibilidade do reconhecimento de processos entre esferas federal, estadual e municipal.

Uma terceira frente de estudos, sugerida pelos resultados deste trabalho é estudar qual o alcance da metodologia de história de vida para fins de avaliação psicológica e subsídio de processos de gestão.

A articulação entre categorias de análise oriundas de teorias psicológicas, antropológicas e administrativas corrobora a necessidade de estabelecimento de estratégias interdisciplinares e transdisciplinares de formação e articulação de pesquisadores, para uma abordagem mais enriquecida de objetos comuns.

Por fim, o maior desafio à teoria administrativa é a constituição de uma proposta de gestão que considere as singularidades do Terceiro Setor, sem perder de vista a sua efetividade, ou seja, a construção de uma administração de organizações do 
Terceiro Setor que não se restrinja a mera transferência de práticas empresariais, apenas adaptadas a um ambiente jurídico diferente.

O Terceiro Setor, portanto, não é uma realidade a ser transformada, segundo a lógica instrumental do capital, como denunciou Tenório (1999), mas um segmento a ser compreendido atentamente por administradores, em especial, e pelos muitos saberes acadêmicos em geral, para que possa vir a somar o seu potencial de motivação e realização dos sujeitos que nele atuam com ações sociais mais efetivas e transformadoras da sociedade brasileira. 


\section{REFERÊNCIAS BIBLIOGRÁFICAS}

ABREU, Canuto. Bezerra de Menezes: subsídios para a história do Espiritismo no Brasil até o ano de 1895. São Paulo: FEESP, 1991.

ALVES, Mário A. Terceiro Setor: as origens do conceito. In: ENCONTRO NACIONAL DOS PROGRAMAS DE PÓS-GRADUAÇÃO EM ADMINISTRAÇÃO, XXVI, 2002, Salvador, Anais... Salvador: ANPAD, 2002. [cd rom].

ANTHONY, William, PERREWÉ, Pámela, KACMAR, K. Job analysis. In: Human resource management. 3rd. ed. Fort Worth: The Dryden Press, 1999.

AZEVEDO, Sérgio, PRATES, Antônio A. P. Planejamento participativo, movimentos sociais e ação coletiva, Ciências Sociais Hoje, São Paulo, ANPOCS, p. 122-152, 1991.

BARROS, Vanessa A., SILVA, Lílian R. A pesquisa em história de vida. In: GOULART, Iris B. Psicologia organizacional e do trabalho: teoria, pesquisa e temas correlatos. São Paulo: Casa do Psicólogo, 2002.

BECKER, H. S. A história de vida e o mosaico científico. In: Métodos de pesquisa em ciências sociais. (2 ed.) São Paulo: Hucitec, 1994.

BERGER \& LUCKMANN. The social construction of reality. New York, Anchor Books, 1967.

BION, W.R. Experiências com grupos: os fundamentos da psicoterapia de grupo. (2 ed). Rio de Janeiro, Imago; São Paulo, Edusp, 1975.

BOBBIO, Norberto. O conceito de sociedade civil. Rio de Janeiro: Graal, 1982.

BOWDITCH, James; BUONO, Anthony. Elementos de comportamento organizacional. São Paulo: Pioneira, 1992.

CARDOSO, Ruth. Fortalecimento da sociedade civil. In: IOSCHPE, Evelyn Berg. $3^{\circ}$ setor: desenvolvimento social sustentado. São Paulo: GIFE, Paz e Terra, 1997.

CARVALHO NETO, Antônio. A negociação da participação nos lucros e resultados: estudo em quatro setores dinâmicos da economia brasileira, Revista de Administração Contemporânea, Curitiba, v. 5, n. 1, p. 195-214, 2001.

CAVACANTI, Maria Laura Viveiros de Castro. O mundo invisível: cosmologia, sistema ritual e noção de pessoa no Espiritismo. Rio de Janeiro: Zahar, 1983.

CEATS-USP. Estratégias de empresas no Brasil: atuação social e voluntariado. São Paulo: Conselho da Comunidade Solidária, SENAC-SP, CIEE, GIFE, CEATS-USP, 1999.

CHIANCA, Thomaz, MARINO, Eduardo, SCHIESARI, Laura. Desenvolvendo a cultura de avaliação em organizações da sociedade civil. São Paulo: GLOBAL, 2001.

COELHO, Simone de Castro Tavares. Terceiro Setor: um estudo comparado entre Brasil e Estados Unidos. São Paulo: Editora SENAC, 2000. 
CONSELHO NACIONAL DE ASSISTÊNCIA SOCIAL. Entidades registradas no CNAS. Disponível na internet via http://www.assistenciasocial.gov.br/iframe/cnas/cnas.htm. Acesso em 21 de setembro de 2003.

CRUZ, Marcus Vinícius, QUEIROZ, Jaime, SAMPAIO, Jáder. Cultura organizacional: um estudo sobre a administração pública de Minas Gerais. in: GOULART, Íris, SAMPAIO, Jáder. Psicologia do trabalho e gestão de recursos humanos: estudos contemporâneos. São Paulo: Casa do Psicólogo, 1998.

DAMAZIO, Sylvia F. Da elite ao povo: advento e expansão do Espiritismo no Rio de Janeiro. Rio de Janeiro: Bertrand Brasil, 1994.

DAVID McClelland, former professor of Psychology, dies. The Harvard University gazette. 9 Apr $1998 . \quad$ Disponível em: http://www.news.harvard.edu/gazette/1998/04.09/DavidMcClelland.html. Acesso em 15 oct. 2003

DE BRUYNE, Paul, HERMAN, Jacques; SCHOUTHEETE, Marc. Dinâmica da pesquisa em ciências sociais. Rio de Janeiro: Francisco Alves, 1991.

DEJOURS, C. Ciências empírico-analíticas e ciências histórico-hermenêuticas. In: $O$ fator humano. São Paulo: FGV, 1997.

Psicodinâmica do trabalho. São Paulo: Atlas, 1994.

- A loucura do trabalho: estudo de psicopatologia do trabalho. 5 ed. São Paulo: Cortez, 1992.

Uma nova visão do sofrimento humano nas organizações. In: CHANLAT, Jean-François (org.) $O$ indivíduo na organização: dimensões esquecidas. 2 ed. São Paulo: Atlas, 1993.

DEJOURS, Christophe et al. Por um trabalho, fator de equilíbrio. Revista de Administração de Empresas, São Paulo, v 33, n 3, p. 98 - 104, maio/jun. 1993.

DUNCAN, Jack. A proposal for multimethod approach to organizational culture research. [S.1: s.n.]1988. Datilografado.

DUTRA, Joel Souza. Administração de carreiras: uma proposta para repensar a gestão de pessoas. São Paulo: Atlas,1996.

FALCONER, Andrés, VILELA, Roberto. Recursos privados para fins públicos: as grantmakers brasileiras. São Paulo: Peirópolis, 2001.

FERNANDES, Rubem César. O que é Terceiro Setor. In: $3^{\circ}$. setor: desenvolvimento social sustentado. São Paulo: GIFE/Paz e Terra, 1997.

FERRARI, Alfonso Trujillo. Metodologia da pesquisa científica. São Paulo: McGraw Hill, 1982.

FISCHER, André Luiz. A constituição do modelo competitivo de gestão de pessoas no Brasil - um estudo sobre as empresas consideradas exemplares. 1998. 392 f. Tese (Doutorado em Administração) - Faculdade de Economia, Administração e Contabilidade, Universidade de São Paulo, São Paulo, 1998. 
FISCHER, Rosa M.; FALCONER, Andres P. Social labeling against child labor: brasilian experiences. São Paulo: ILO/FEA-USP, 2000.

CEATS, 1999.

Estratégias de empresas no Brasil: atuação social e voluntariado. São Paulo:

Desafios da parceria governo e Terceiro Setor, Revista de Administração, São Paulo, v. 33, n. 1, p. 12-19, jan./mar. 1998.

FISHER, Cynthia, SCHOENFELDT, Lyle, SHAW, James. Job analysis: concepts, procedures and choices. Human resource management. (4 ed.) Boston: Houghton Mifflin, 1999.

FLEURY, M. T. L., FISCHER, R. Relações de trabalho e políticas de gestão: uma história das questões atuais, Revista de Administração, São Paulo, v. 27, n. 4, out./dez. 1992.

FLEURY, A., FLEURY, M. T. L. Aprendizagem e inovação organizacional: as experiências de Japão, Coréia e Brasil. São Paulo: Atlas, 1995.

Estratégias empresariais e formação de competências: um quebra-cabeça caleidoscópico da indústria brasileira. São Paulo: Atlas, 2000.

FLEURY, M.T.L. \& FISCHER, R.M. (org.). Cultura e poder nas organizações. São Paulo, Atlas, 1989.

FLEURY, M. T. L., SHINYASHIKI, G., STEVANATO, L. A. Entre a antropologia e a Psicanálise: dilemas metodológicos dos estudos sobre cultura organizacional, Revista de Administração, São Paulo, v. 32, n. 1, p. 23-37, jan./mar. 1997a.

Arqueologia teórica e dilemas metodológicos dos estudos sobre cultura organizacional. In: MOTTA, Fernando C. P., CALDAS, Miguel (org.). Cultura organizacional e cultura brasileira. São Paulo: Atlas, 1997b.

FLEURY, M. T. L., SAMPAIO, J. Uma discussão sobre cultura organizacional. In: FLEURY, M. T. L. (org.) As pessoas na organização. São Paulo: Gente, 2002.

FRANÇA, Júnia L. et al. Manual para normalização de publicações técnico científicas.(4 ed.) Belo Horizonte: Editora UFMG, 2000.

FRANZOLIM, Ivan René. Quantos brasileiros são espíritas. Disponível em: http://www.panoramaespirita.com.br/artigos/quantos_bras_espiritas.html Acesso em 15 out. 2003.

FREITAS, Maria Éster de. Missão da empresa: a construção carismática moderna? In: Cultura organizacional: identidade, sedução e carisma? São Paulo: Editora FGV, 2000.

GEERTZ, Clifford. A interpretação das culturas. Rio de Janeiro: LTC, 1989.

GIL, Antônio Carlos. Como elaborar projetos de pesquisa. São Paulo: Atlas, 1988.

GIUMBELLI, Emerson. Caridade, assistência social, política e cidadania: práticas e reflexões no Espiritismo. In: LANDIM, Leilah (org.) Ações em sociedade: militância, caridade, assistência, etc. Rio de Janeiro: NAU, 1998.

. O cuidado dos mortos. Rio de Janeiro: Arquivo Nacional, 1997. 
GOMES, William B. A entrevista fenomenológica e o estudo da experiência consciente. In: Fenomenologia e pesquisa em Psicologia. Porto Alegre: Ed. Universidade/UFRGS, 1998.

HASLAM, S. A. Psychology in organizations: the social identity approach. London: SAGE, 2001.

HASLAM, S. A., POWELL, C., TURNER, JOHN, C. Social identity, selfcategorization and work motivation: rethinking the contribution or the group to positive and sustainable organizational outcomes, Applied psychology: an international review, v. 49, n. 3, p. 319-339, jul. 2000.

HIPÓLITO, José A. M. Administração salarial: a remuneração por competências como diferencial competitivo. São Paulo: Atlas, 2001.

HOFFMAN, Edward. Abraham Maslow: Father of Enlightment Management, Training, p. 79-82, set. 1988.

HOFSTEDE, Geert. Attitudes, values and organizational culture: disentangling the concepts. Organization studies, v. 19, n. 3, p. 477-492, 1998.

Cultural constraints in management theories. Academy of management executive, v. 7, n. 1, p. 81-94, 1993.

The poverty of management control philosophy. Academy of management review, Birarcliff Manor, p. 450-461, jul. 1978.

The cultural relativity of organizational practices and theories. Journal of international Business Studies, Atlanta, v. 14, n. 2, p. 75-89, 1983a.

An American in Paris: the influence of nationality on organization theories, Organization Studies, Berlin, v. 17, n. 3, p. 525-537, 1996.

HOFSTEDE, Geert, NEUIJEN, Bram, OHAYV, Denise, SANDERS, Geert. Measuring organizational cultures: a qualitative and quantitative study across twenty cases. Administrative Science Quarterly, Ithaca, v. 35, n. 2, p. 286-316, 1990.

HOFSTEDE, Geert, BOND, Michael H., LUK, Chung-Ieung. Individual perceptions of organizational cultures: a methodological treatise on levels of analysis. Organization Studies, v. 14, n. 4, p. 483-503, 1983 b.

INSTITUTO BRASILEIRA DE GEOGRAFIA E ESTATÍSTICA. Última etapa de divulgação do Censo 2000 traz os resultados definitivos, com informações sobre os 5.507 municípios brasileiros. Disponível na internet via http://www.ibge.gov.br/home/presidencia/noticias/20122002censo.shtm. Acessado em 08 de julho de 2003.

KANT, Immanuel. Da doutrina transcendental dos elementos. In: Crítica da razão pura. São Paulo: Nova Cultural, 1987.

KARDEC, Allan. O livro dos espíritos.(44. ed. popular) Rio de Janeiro: FEB, 1978a.

KARDEC, Allan. O evangelho segundo o Espiritismo. (76. ed) Rio de Janeiro: FEB, 1978b.

KARDEC, Allan. Obras póstumas. (17. ed.) Rio de Janeiro: FEB, 1978c. 
KARDEC, Allan. O que é o Espiritismo. (22. ed) Rio de Janeiro: FEB, 1980.

KURZ, Robert. Para além do estado e do mercado. In: Os últimos combates. Rio de Janeiro: Vozes, 1997.

KLUCKHOHN, F.R. Orientações de valor dominantes e variantes. In: KLUCKHOHN, C.; MURRAY, I.I.; SCHNEIDER, M. Personalidade: na natureza, na sociedade e na cultura. Belo Horizonte, Itatiaia, 1965, v.1.

LANDIM, Leilah. "Experiência militante": histórias das assim chamadas ONGs. In: LANDIM, Leilah (org.) Ações em sociedade: militância, caridade, assistência, etc. Rio de Janeiro: NAU, 1998.

LANDIM, Leilah, BERES, Neide. Ocupações, despesas e recursos: as organizações sem fins lucrativos no Brasil. Rio de Janeiro: NAU, 1999.

LEWGOY, Bernardo. Etnografia da leitura e da fala num grupo de estudos espírita. In: JORNADAS SOBRE ALTERNATIVAS RELIGIOSAS NA AMÉRICA LATINA, VIII, 1998, São Paulo, Anais... São Paulo, 1998.

Chico Xavier e a cultura brasileira. Rev. Antropol., , v.44, n. 1, p.53-116, 2001.

MACHADO, Ubiratan. Os intelectuais e o Espiritismo. Niterói: Publicações Lachâtre, 1996.

MADSEN, K. B. La teoria de McClelland. In: MADSEN, K. B. Teorias de la motivación. Buenos Aires: Editorial Paidós, 1967.

MAIOR, Marcel S. As vidas de Chico Xavier. 2 ed. São Paulo: Planeta, 2003.

MARÇON, Denise, ESCRIVÃO FILHO, Edmundo. Gestão das organizações do Terceiro Setor: um repensar sobre as teorias organizacionais. In: ENCONTRO NACIONAL DOS PROGRAMAS DE PÓS-GRADUAÇÃO EM ADMINISTRAÇÃO, XXVI, 2002, Salvador, Anais... Salvador: ANPAD, 2001. [cd rom].

MARTINELLI, Antônio Carlos. Empresa cidadã: uma visão inovadora para uma ação transformadora. in: IOSCHPE, Evelyn Berg. $3^{\circ}$ setor: desenvolvimento social sustentado. São Paulo: Paz e Terra, 1997.

MARX, Roberto. Trabalho em grupos e autonomia como instrumentos de competição. São Paulo: Atlas, 1998.

MASCARENHAS, André O., ZAMBALDI, Felipe. Motivação em programas de voluntariado empresarial: um estudo de caso. In: ENCONTRO NACIONAL DOS PROGRAMAS DE PÓS-GRADUAÇÃO EM ADMINISTRAÇÃO, XXVI, 2002, Salvador, Anais... Salvador: ANPAD, 2002. [cd rom].

MARRAS, Jean Pierre. Análise de função e descrição de cargo. In: Administração da remuneração. São Paulo: Pioneira Thomsom Learning, 2002.

MASLOW, Abraham H.. Motivation and personality. New York: Harper \& Brothers, 1954.

Eupsychian management: a journal.17 ed. Illinois-EUA: Richard Irwin, 1974.

Maslow no gerenciamento. Rio de Janeiro: Qualitymark, 2001. 
Toward a psychology of being. $3^{\text {rd }}$ ed. New York: John Wiley and Sons, 1998.

Introdução à psicologia do ser. 2 ed. Rio de Janeiro: Itatiaia, s.d.

Books, 1993.

Metamotivation. In: The farther reaches of human nature. New York: Penguin

MATRAJT, Miguel. Prevenção de estresse ocupacional em linha de montagem: um estudo de caso mexicano. Revista de Administração de Empresas, São Paulo, Fundação Getúlio Vargas, v. 33, n. 5, p. 98-108, 1993.

MCCLELLAND, David. Power motivation and organizational leadership. In: Power: the inner experience. New York: Irvington, 1975.

A sociedade competitiva: realização e progresso social. Rio de Janeiro: Expressão e Cultura, 1972.

. The achievement motive. New York: Appleton Century Crofts, 1953.

. Notes for a revised theory of motivation. In: MCCLELLAND, David. (org.)

Studies in motivation. New York: Appleton-Century-Crofts, 1955a.

. Measuring motivation in phantasy. In: MCCLELLAND, David. (org.) Studies in motivation. New York: Appleton-Century-Crofts, 1955b.

. Issues for the identification of talent. In: MCCLELAND et al. Talent and society. new perspectives in the identification of talent. New Jersey: Van Nostrand, 1959.

. Personality. New York: Holt, Rhinehart and Winston, 1967.

Testing for competence rather than for "intelligence". American Psycologist, p. 1-14, jan. 1973.

MCCLELLAND, David, BURHAM, David. O poder é o grande motivador. In: VROOM, Victor (org.) Gestão de pessoas, não de pessoal. Rio de Janeiro: CAMPUS, 1997.

MCCURLEY, Stephen. Recruiting and retaining volunteers. In: HERMAN, R. (org.) The Jossey-Bass Handbook of nonprofit leadership and management. San Francisco: Jossey-Bass, 1994.

MEISTER, Jeanne. Educação corporativa: a gestão do capital intelectual através das universidades corporativas. São Paulo: Makron Books, 1999.

MELO, Vanessa, FISCHER, Tânia, SOARES JÚNIOR, Jair S. Diversidades e confluências no campo do Terceiro Setor: um estudo de organizações baianas. In: ENCONTRO NACIONAL DOS PROGRAMAS DE PÓS-GRADUAÇÃO EM ADMINISTRAÇÃO, XXVI, 2003, Atibaia, Anais... Atibaia: ANPAD, 2003. [cd rom].

MELO NETO, Francisco P., FROES, César. Responsabilidade social \& cidadania empresarial: a administração do Terceiro Setor. (2 ed.) Rio de Janeiro: Qualitymark, 2001.

MINAYO, M. C. S. Pesquisa social: teoria, método e criatividade. 4.ed. Petrópolis: Vozes, 1994. 
MUCCHIELLI, Alex. Les motivations. Paris: PUF, 1981.

MULHARE, Eileen. Mindful of the future: strategic planning ideology and the culture of nonprofit management, Human organization, v. 58, n. 3, p. 323-330, 1999.

MURRAY, Henry A. Types of human needs. In: In: MCCLELLAND, David. (org.) Studies in motivation. New York: Appleton-Century-Crofts, 1955.

NUTTIN, Joseph. A estrutura da personalidade. São Paulo: Duas Cidades, 1969.

Théorie de la motivation humaine: du besoin au projet d'action. Paris, PUF, 1980.

OFFE, Claus. The present historical transition and some basic design options for societal institutions. in: Seminário Internacional "Sociedade e a Reforma do Estado". São Paulo: MARE, 1998.

OLSON, Mancur. A lógica da ação coletiva. São Paulo: EDUSP, 1999.

O'NEILL, Michael. Nonprofit management education: US and world perspectives. London: Praeger, 1998.

PEREIRA, William César Castilho. O adoecer psíquico do subproletariado. Belo Horizonte: SEGRAC, 1990.

PORTER, Michael, KRAMER, Mark R. A vantagem competitiva da filantropia corporativa, Harvard Business Review, v. 80, n. 2, p. 42-54.

RAUSCHENBERGER, John, SCHMITT, Neal, HUNTER, John. A test of the need hierarchy concept by a Markov model of change in need strength, Administrative Science Quarterly, Ithaca, v. 25, n. 4, p. 654-670, dez. 1980.

ROBBINS, Stephen. Comportamento organizacional. São Paulo, LTc, 1999.

ROESCH, Sylvia. Gestão de ONGs - rumo a uma agenda de pesquisa que contemple a sua diversidade. In: ENCONTRO NACIONAL DOS PROGRAMAS DE PÓSGRADUAÇÃO EM ADMINISTRAÇÃO, XXVI, 2002, Salvador, Anais... Salvador: ANPAD, 2002. [cd rom].

SALAMON, Lester. Estratégias para o fortalecimento do Terceiro Setor. In: IOSCHPE, Evelyn Berg. $3^{\circ}$ setor: desenvolvimento social sustentado. São Paulo: GIFE, Paz e Terra, 1997.

SAMPAIO, Jáder R. A pesquisa qualitativa entre a fenomenologia e o empirismo formal, Revista de Administração, São Paulo, v. 36, n. 2, p. 16-24, abr./jun. 2001.

NIPO-BRASILEIROS: Um estudo sobre a gestão de recursos humanos de empresas industriais japonesas situadas no Brasil.1995. 204 f. Dissertação (Mestrado em Administração) - Faculdade de Ciências Econômicas, Universidade Federal de Minas Gerais, Belo Horizonte, 1995. [Dissertação de Mestrado]

A "dinâmica de grupos" de Bion e as organizações de trabalho, Psicologia USP, São Paulo, v. 13, n. 2, p. 277-291, 2002.

SAMPAIO, Jáder e TAVARES, Karlyson. Gestão de recursos humanos de empresas públicas e sociedades de economia mista do estado de Minas Gerais: uma análise da 
estrutura e programas de T\&D. Belo Horizonte: FAFICH/UFMG, 1999. 120 p. Relatório.

SCHEIN, Edgar H. Guia de sobrevivência da cultura corporativa. Rio de Janeiro: José Olympio, 2001.

Legitimating clinical research in the study of organizational culture, Journal of Counseling \& Development, v. 71, p. 703-708, jul./ago. 1993.

. Organizational culture and leadership. (2 ed.) San Francisco, Jossey Bass, 1992.

Replanejamento de cargos e funções. São Paulo: Nobel, 1996.

SCHINDLER-RAINMAN, Eva. Motivating people to volunteer their services. In: CONNORS, Tracy. (org.) The non-profit organization handbook. New York: Mc. Graw Hill, 1980.

SCHNEIDER, BENJAMIN, ALDERFER, CLAYTON P. Three studies of measures of need satisfaction in organizations, Administrative Science Quarterly, Ithaca, v. 18, n. 4, p. 489-505, 1973.

SIEVERS, Buckhart. Além do sucedâneo da motivação. in: BERGAMINI, Cecília W., CODA, Roberto (org.) Psicodinâmica da vida organizacional: motivação e liderança.(2 ed) São Paulo: Atlas, 1997.

SILVA, Eliana Moura. Reflexões históricas e teóricas sobre o espiritualismo entre 1850-1930. Campinas: UNICAMP, 1997. Disponível na internet via http://www.unicamp.br/ elmoura/O Espiritualismo nos Séc. XIX e XX.doc. Acessado em 18 de maio de 2003.

SILVA, Heliana M. Novos arranjos para a gestão das políticas sociais: a estratégia Comunidade Solidária, Revista de Administração Pública, v. 33, n. 5, p. 103-113, set./out. 1999.

SMIRCICH, Linda. Concepts of culture and organizational analysis. Administrative Science Quarterly, v. 28, n. 3, p. 339-358, set. 1983.

STERN, Gary. Terceiro Setor: ferramenta de auto-avaliação para empresas. São Paulo: Futura, 2001.

STOLL, Sandra J. Entre dois mundos: o Espiritismo da França e no Brasil. 1999. 255 f. Tese (Doutorado em Antropologia) - Faculdade de Filosofia, Letras e Ciências Humanas, Universidade de São Paulo, São Paulo, 1999.

SZAZI, Eduardo. Terceiro Setor: regulação no Brasil. São Paulo: Peirópolis, 2000.

TACHIZAWA, Takeshy. Organizações não governamentais e Terceiro Setor: criação de ONGs e estratégias de atuação. São Paulo: Atlas, 2002.

TANDON, Rajesh. Civil society, the state and roles of NGOs, IDR reports, Boston, v. 8, n. 3, 1991. Disponível em: <www.jsi.com/idr/pubs.htm> Acesso em 10 de dezembro de 2003.

TENÓRIO, Fernando. Gestão de ONGs: principais funções gerenciais. São Paulo: FGV, 1998. 
Um espectro ronda o Terceiro Setor: o espectro do mercado, Revista de Administração Pública, v. 33, n. 5, p. 85-102, set./out. 1999.

THIOLLENT, Michel. Problemas de metodologia. In: FLEURY, Afonso C. C., VARGAS, Nilton. Organização do trabalho: uma abordagem interdisciplinar. São Paulo: Atlas, 1983. . Metodologia da pesquisa-ação. São Paulo: Cortez, 1986. . Pesquisa-ação em organizações. São Paulo: Atlas, 1997.

TORRES, Ciro. Um pouco da história do balanço social. Disponível na internet via http://www.balancosocial.org.br/historico.html. Arquivo capturado em 29 de março de 2000.

ULRICH, Dave. Os campeões de recursos humanos. São Paulo: Futura, 1998.

ULRICH, Dave (org). Recursos humanos estratégicos: novas perspectivas para os profissionais de RH. São Paulo: Editora Futura, 2000.

UNIÃO ESPÍRITA MINEIRA. Instituições espíritas do estado de Minas Gerais. Disponível na internet via http://www.uembh.org.br/htm/instituicao_completa.htm. Arquivo capturado em 10 de setembro de 2003.

VROOM, Victor. Work and motivation. New York: John Wiley, 1964.

WAGNER III, John, HOLLENBACK, John. Comportamento macroorganizacional. in: Comportamento organizacional: criando vantagem competitiva. São Paulo: Saraiva, 2000.

WOOD Jr., Thomaz, PICARELLI Fo., Vicente. Remuneração por habilidades e por competências: preparando a organização para a era das empresas de conhecimento intensivo. São Paulo: ATLAS, 1999.

WILSON, Robert. Understanding local governance: an international perspective. Revista de Administração de Empresas, São Paulo, v. 40, n. 2, p. 51-63, abr./jun. 2000.

YIN, Robert. Estudo de caso: planejamento e métodos. 2.ed. Porto Alegre: Bookman, 2001.

ZILLES, Urbano. Teoria do conhecimento. Porto Alegre: EDIPUCRS, 1994. 


\section{ANEXOS}

\subsection{ANEXO 1}

\section{PONTOS FOCAIS DA HISTÓRIA DE VIDA DOS VOLUNTÁRIOS DA CRECHE X.}

Proposta geral:

Estamos realizando um trabalho de pesquisa sobre os voluntários. Gostaríamos que você nos contasse a história da sua vida de voluntário, desde a sua primeira experiência. Gostaríamos que você nos contasse com detalhes o que fez, como se sentiu, quais os problemas e satisfações que vivenciou.

Pontos a serem explorados durante a entrevista:

1. As diversas experiências de vida como voluntário.

2. Como ele se tornou voluntário?

3. Como ele chegou a esta creche?

4. Quais as atividades que realizou?

5. Quais as metas e objetivos que se colocou durante sua trajetória?

6. Houve momentos em que sentiu vontade de parar? Como aconteceram? Por que não parou? 
7. Quais foram as grandes satisfações e alegrias que sentiu?

8. Que situações no trabalho atual o desanimam ou aborrecem?

9. Que situações no trabalho atual são gratificantes e despertam a vontade do sujeito realizar o trabalho?

10. Que pessoas influenciaram a decisão de voluntariar-se? (Família, amigos, membros do grupo religioso, etc.) 


\subsection{ANEXO 2}

\section{ANÁLISE DE ATIVIDADES}

\section{ORGANIZAÇÃO: ASSOCIAÇÃO OTS \\ UNIDADE: CRECHE FUTURO}

Título da Atividade:

Vínculo principal com a organização:

Descrição da Atividade

1. Descrição Sumária: (Atividade como um todo)

2. Descrição Detalhada: (Tarefas)

Especificação da Atividade: (Perfil necessário/desejado do ocupante)

1. Conhecimentos: (Necessários e Desejados) 
2. Experiência anterior: (Necessária e Desejável)

3. Máquinas, Ferramentas e Equipamentos Utilizados:

4. Características Pessoais: (Desejáveis)

\section{Análise de Atividades para Trabalho Voluntário}

1. Existem voluntários realizando alguma das atividades acima? Quais?

2. Gostaria de contar com a ajuda de voluntários no trabalho que realiza?

$$
\text { Sim Não }
$$

3. Quais das atividades acima necessitam de voluntários para serem realizadas?

4. Quais das atividades descritas acima poderiam ser realizadas com a ajuda de voluntários? 